\title{
Justice and Efficiency in Mega-Litigation
}

\author{
Anna Olijnyk \\ Thesis submitted for the degree of Doctor of Philosophy \\ Adelaide Law School \\ The University of Adelaide
}

October 2014 


\section{CONTENTS}

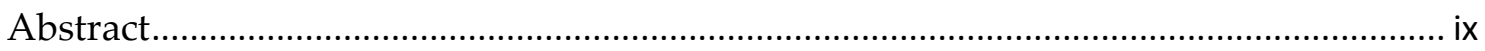

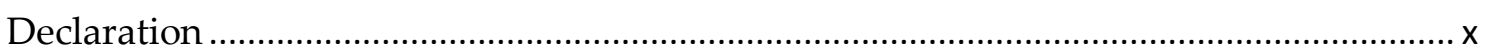

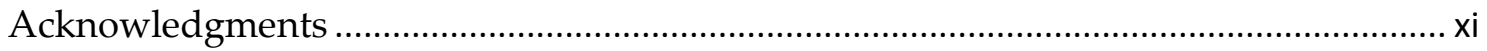

Note on Referencing Conventions ............................................................................ xii

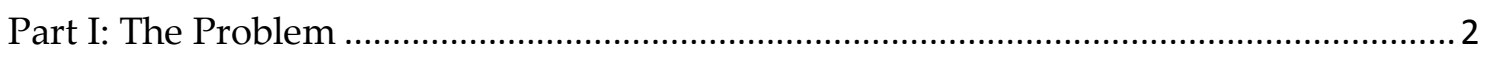

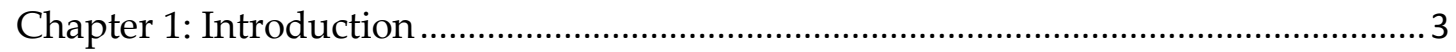

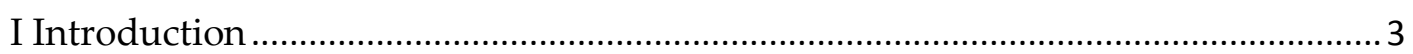

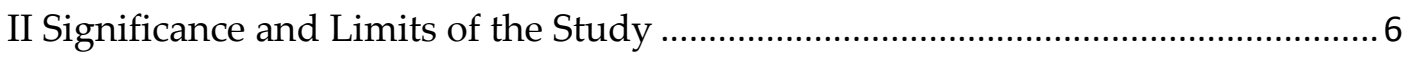

III Methodology and Structure................................................................................ 8

Chapter 2: Justice and Efficiency as Aims of Civil Procedure ....................................... 12

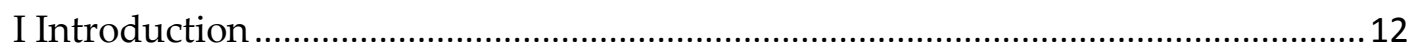

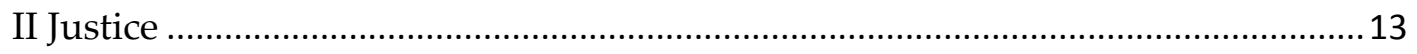

A Justice Between the Parties ........................................................................... 13

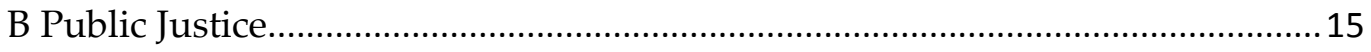

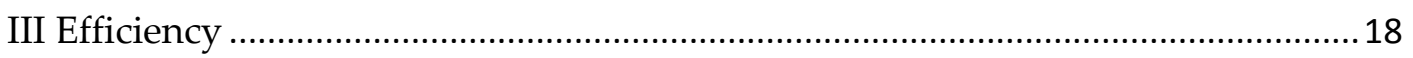

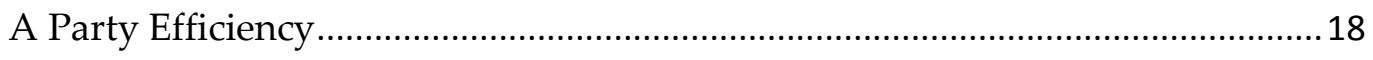

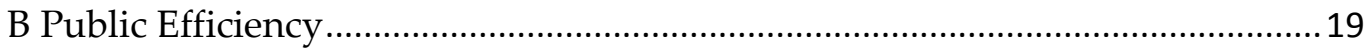

IV Relationship Between Party and Public Perspectives on Justice and Efficiency 22

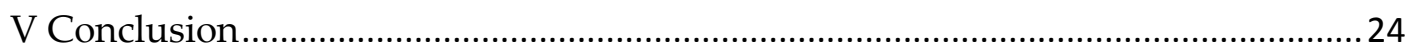

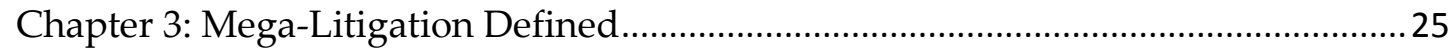

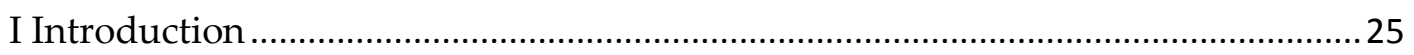

II Towards a Definition of Mega-Litigation ........................................................... 26

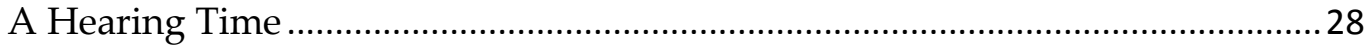

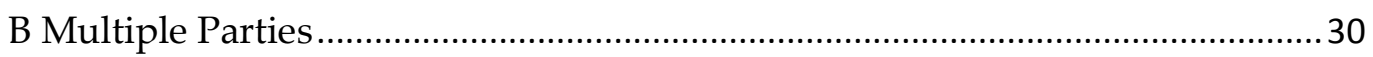

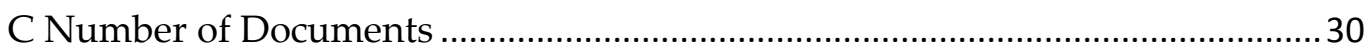

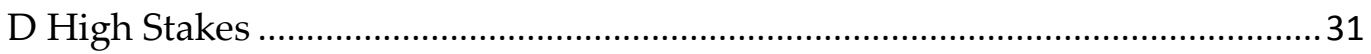




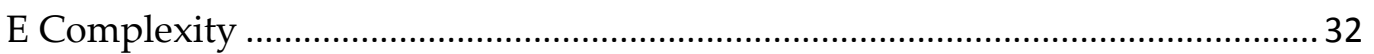

III Qualitatively Different From Ordinary Litigation?............................................. 34

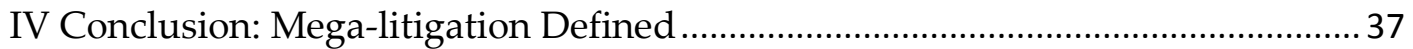

Chapter 4: Mega-Litigation: A Challenge for the Justice System .................................. 40

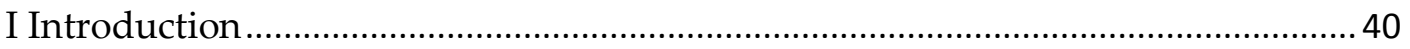

II Mega-Litigation: A Problem For the Justice System.............................................. 41

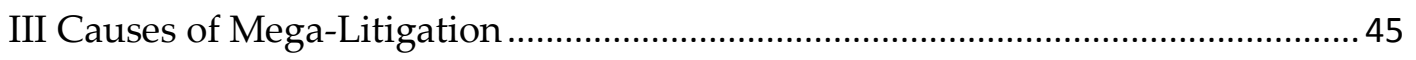

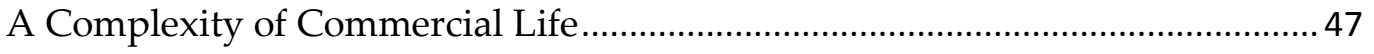

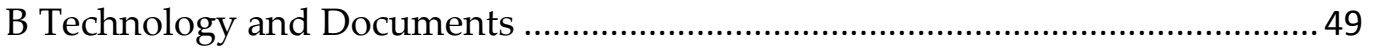

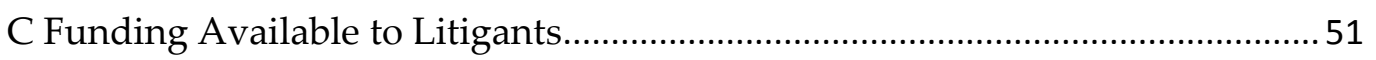

D Individualised Justice in the Substantive Law ................................................... 53

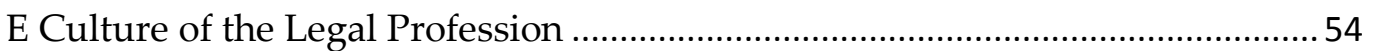

IV Is There Tension Between Justice and Efficiency in Mega-Litigation?..................56

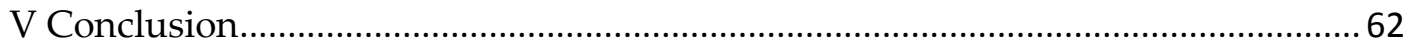

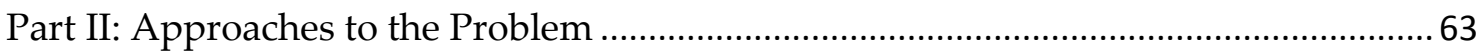

Chapter 5: Justice and Efficiency in Civil Procedure: Theoretical Perspectives........... 64

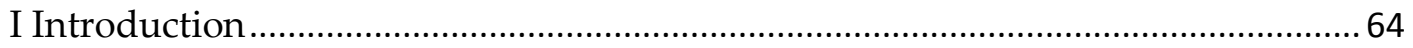

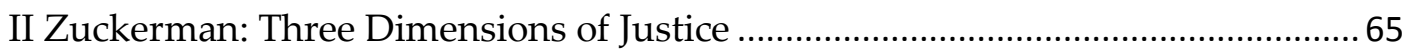

III Posner: Economic Analysis of Civil Procedure.................................................... 68

IV Dworkin: A Rights-Based Approach .................................................................. 71

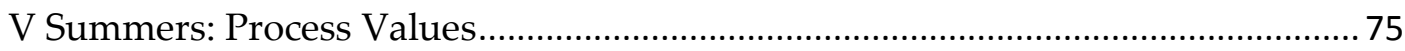

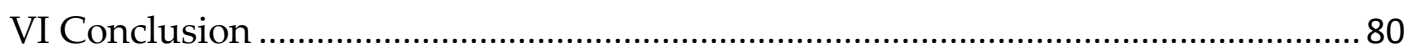

Chapter 6: A Brief History of Justice and Efficiency in Civil Procedure ....................... 82

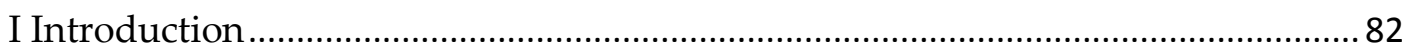

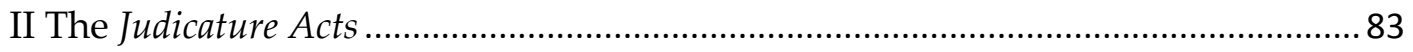

III Post-Judicature Acts: Justice Between the Parties .................................................... 85

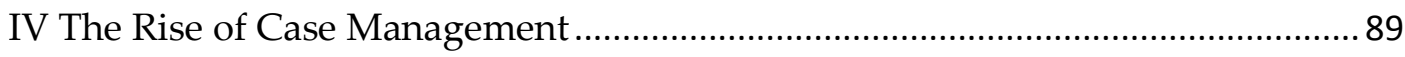

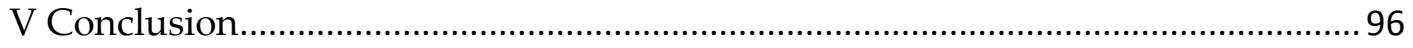

Chapter 7: Justice and Efficiency in Civil Procedure: The Current Australian Position

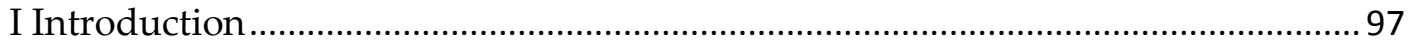

II Constitutional Limits on Civil Procedure …................................................................ 98 


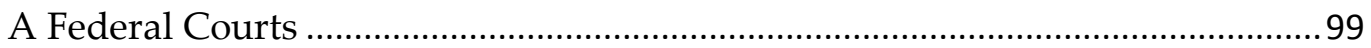

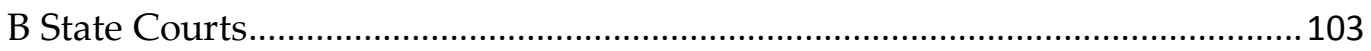

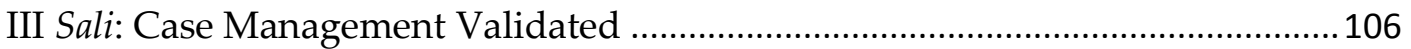

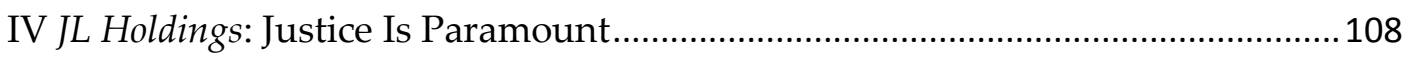

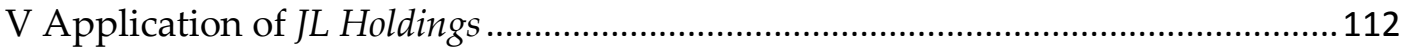

VI Overarching Purpose Rules: Overturning JL Holdings .......................................115

VII Aon: Case Management Rises Again................................................................ 118

VIII Expense Reduction: Aon Reaffirmed .................................................................... 124

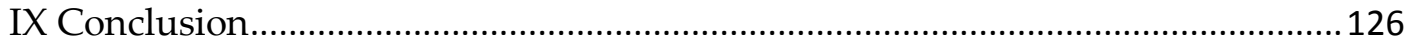

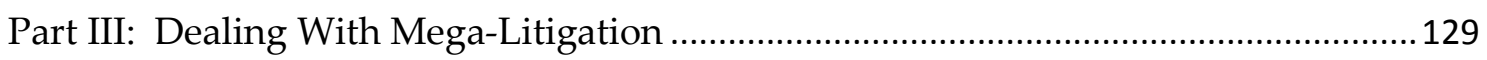

Chapter 8: The Mega-Litigation Judge ....................................................................... 130

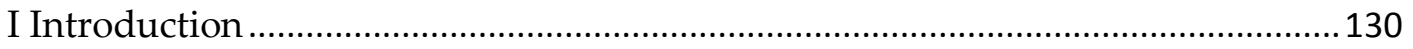

II Characteristics of the Mega-Litigation Judge ...................................................... 131

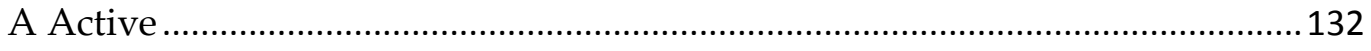

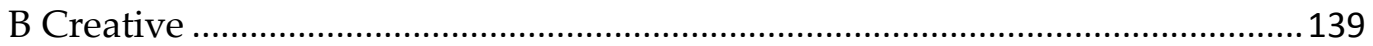

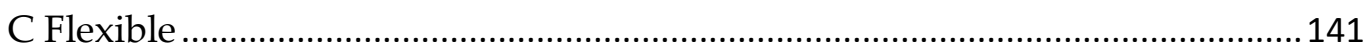

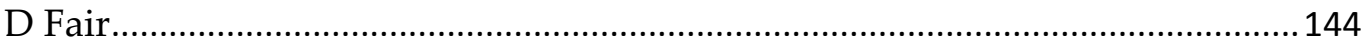

III Personality and Experience ………................................................................... 149

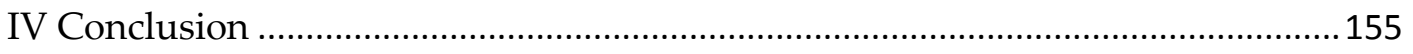

Chapter 9: Procedural Techniques in Mega-Litigation................................................157

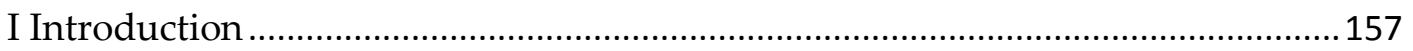

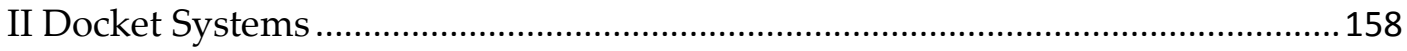

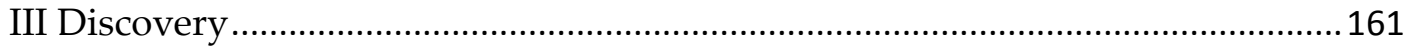

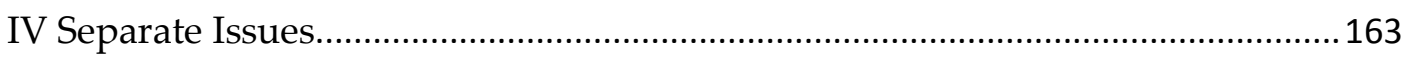

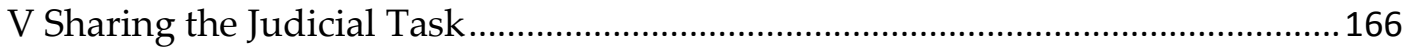

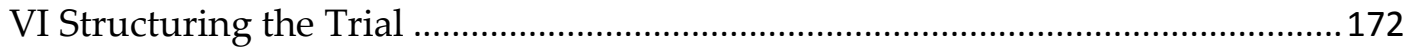

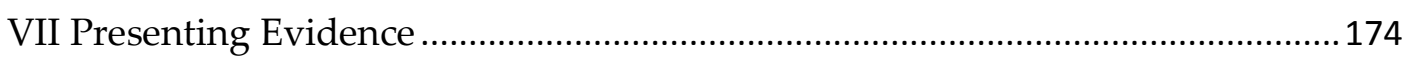

A Documentary Evidence ……………………............................................. 175

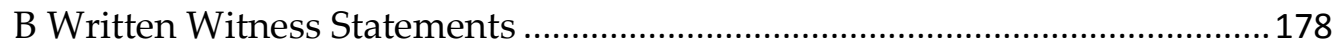

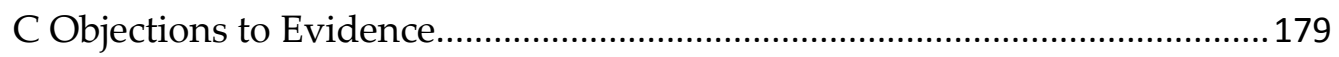

D Limits on Cross-Examination .................................................................. 181 


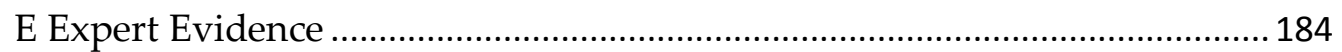

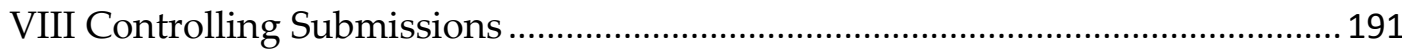

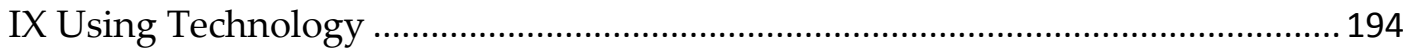

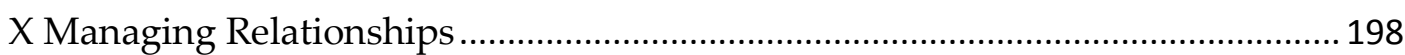

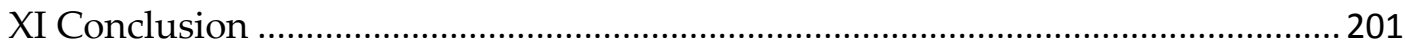

Chapter 10: Justice and Efficiency in Mega-Litigation.................................................... 204

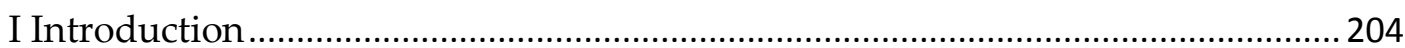

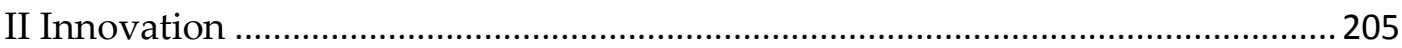

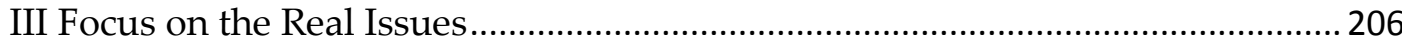

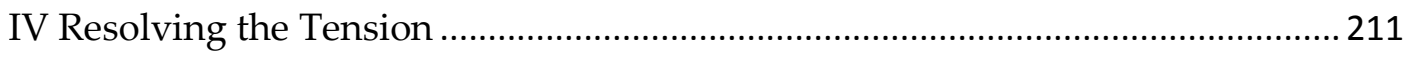

A Rules and Procedural Legislation .................................................................... 212

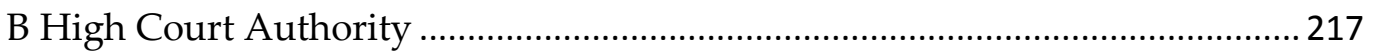

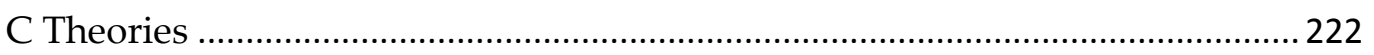

1 Zuckerman: Three Dimensions of Justice ..................................................... 223

2 Posner: Economic Analysis of Civil Procedure................................................ 225

3 Dworkin: Moral Harm and Procedural Rights ............................................... 227

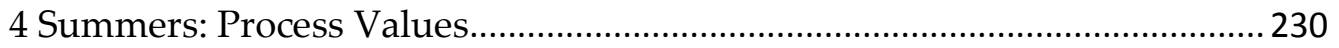

5 The Role of Theory in Procedural Decision-Making...................................... 233

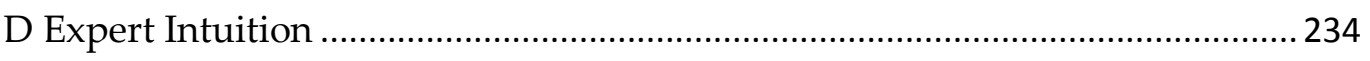

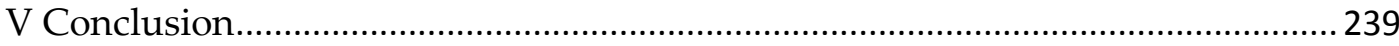

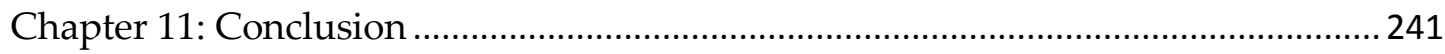

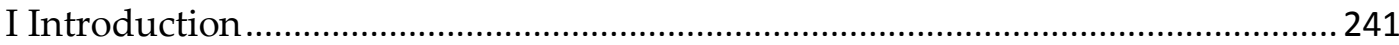

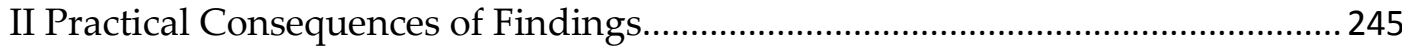

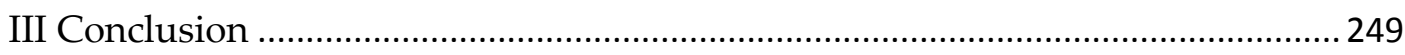

Appendix A: Qualitative Research Methodology …….................................................. 251

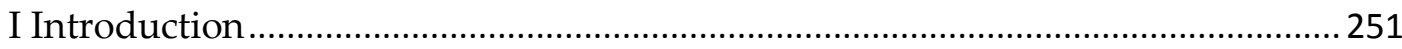

II Selection of Interview Participants .................................................................. 251

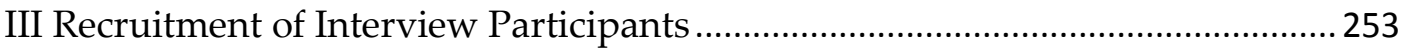

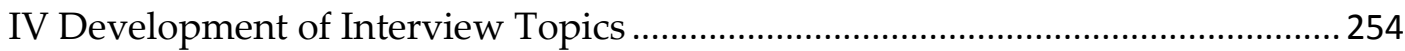

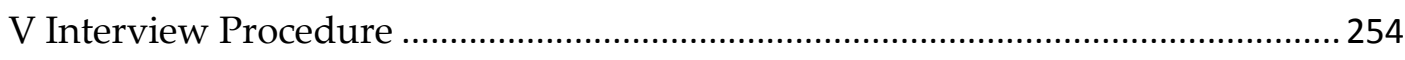

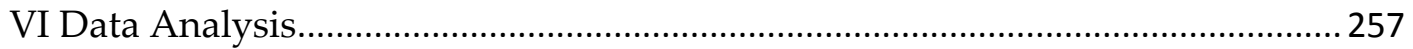


VII Participant Review and Anonymity 258

VIII Limitations of Study.. 259

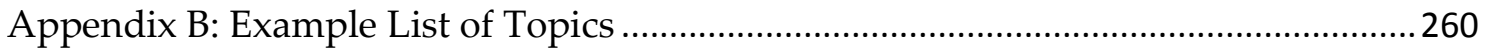

Bibliography... 263 


\begin{abstract}
This thesis asks how Australian judges reconcile the demands of efficiency and justice in extremely long-running, complex civil litigation - sometimes known as 'mega-litigation'. The thesis combines doctrinal and theoretical analysis with qualitative research based on a series of interviews with judges who have presided over mega-litigation.
\end{abstract}

Mega-litigation places enormous burdens on the justice system, requiring large amounts of court resources to be devoted to a small number of cases. A central theme of the thesis is the need for civil procedure to be directed to multiple aims: efficiency as well as justice, and the interests of the public as well as those of the parties to litigation. It is therefore crucial for courts, when managing mega-litigation, to seek to improve efficiency and to have regard to the interests of the public. At times, there will be tension between these objectives and the objective of doing justice between the parties to the case.

This thesis examines the ways in which the challenge of reconciling justice and efficiency in civil procedure has been approached by scholars and courts. Against this background, qualitative interview data is used to examine how judges approach this challenge in mega-litigation. Ultimately, the thesis identifies three ways in which judges reconcile justice and efficiency in megalitigation: first, by seeking innovative ways to improve efficiency without compromising justice; secondly, by taking control of the litigation from the parties and ensuring that there is a sharp focus on the real issues in dispute; and thirdly, by relying on highly informed expert intuition. All three conclusions rely heavily on the skill, personality and background of the individual judge. 


\section{DECLARATION}

I certify that this work contains no material which has been accepted for the award of any other degree or diploma in my name in any university or other tertiary institution and, to the best of my knowledge and belief, contains no material previously published or written by another person, except where due reference has been made in the text. In addition, I certify that no part of this work will, in the future, be used in a submission in my name for any other degree or diploma in any university or other tertiary institution without the prior approval of the University of Adelaide.

I give consent to this copy of my thesis, when deposited in the University Library, being made available for loan and photocopying, subject to the provisions of the Copyright Act 1968.

I also give permission for the digital version of my thesis to be made available on the web, via the University's digital research repository, the Library Search and also through web search engines. 


\section{ACKNOWLEDGMENTS}

There are many people without whose help I could not have completed this thesis.

I was extremely fortunate to have two excellent supervisors. My primary supervisor, Professor John Williams, constantly kept my eye on the big picture, pushed me to make my work stronger and more original, and fostered my academic career beyond the thesis. My co-supervisor, the Honourable David Bleby QC, provided invaluable help with developing the qualitative interviews and approaching potential interviewees. His ability to (gently) point out the weakness in an argument was a skill that transferred successfully from the role of judge to that of supervisor.

The judges who participated in interviews for this thesis were extremely busy individuals who were asked to give up their time to help a PhD student who (with one exception) was a stranger to them. They all did so with enthusiasm and genuine commitment to the exercise. Their generosity is a credit to the profession.

My family, especially my mother Sarah Olijnyk, were an unfailing source of support. As challenging as the $\mathrm{PhD}$ was for me, at times it must have been more challenging for those around me.

I was accompanied throughout the PhD 'journey' (a word used a lot by postgraduate students who have watched too much reality television) by the most wonderful cohort of PhD students at Adelaide Law School. They read my drafts, alerted me to relevant resources, baked for me, listened to my whinging and provided distraction when needed (and sometimes when not needed).

Various members of the academic and professional staff at Adelaide Law School provided practical and emotional help and inspiration. Special thanks go to Gabrielle Appleby, Sheena Beaven, Peter Burdon, Cheryl Chapman, Moira Groves, Suzanne Le Mire and the Law Library staff. I could not have wished for a more supportive research environment.

I was lucky enough to receive the FA \& MF Joyner Scholarship in Law, the Ian Wilson Liberal Research Scholarship, the Zelling-Gray Scholarship and the Baker Scholarship in Law. The generosity of those who established these scholarships enabled me to devote three years to full-time PhD study.

Finally, I would like to thank Justice Paul Finn for his timely and incisive comments at an early stage of the project. 


\section{NOTE ON REFERENCING CONVENTIONS \\ Interviews}

For the purposes of this project, I conducted a series of interviews with current and former judges with experience in mega-litigation. The methodology of those interviews is explained in the Appendix.

Interview participants were offered the option of anonymity. Half the participants (8 out of 16) took up this option. Those participants who requested anonymity have been allocated a letter at random, and are referred to throughout the thesis as, for example, 'Participant A'. No location of interview has been given for these participants. Due to the small number of potential participants, and the fact that the interviews took place in each participant's home city, location would tend to reveal identity. For the same reason, no date of interview is given: as interviews in each city were conducted within a short period of time (for example a week in Sydney) date would tend to reveal location.

For those participants who did not request anonymity, the interviews are referenced in accordance with rule 6.13 .1 of the Australian Guide to Legal Citation. In the text of the thesis, I have adopted the following convention: the first time an interview participant is referred to in the text of a chapter, they are referred to by their full name and title at the time of interview. In subsequent references in the same chapter, they are referred to by their first name and surname only.

\section{The Bell Group Judgment}

This thesis contains many references to Owen J's judgment in Bell Group Ltd (in liq) $v$ Westpac Banking Corporation (No 9). The judgment has the medium-neutral citation [2008] WASC 239. An abridged version of the judgment appears in the Western Australian Reports with the citation (2008) 39 WAR 1. I have adopted the following conventions when citing this judgment:

- When referring to a paragraph of the judgment that appears in the Western Australian Reports, I have used only the reported citation, and referred to both the paragraph number and the page number of the WAR.

- When referring to a paragraph of the judgment that does not appear in the WAR, I have used both the reported and medium-neutral citations, and referred to the relevant paragraph number. 
Justice and Efficiency in Mega-Litigation 
PART I:

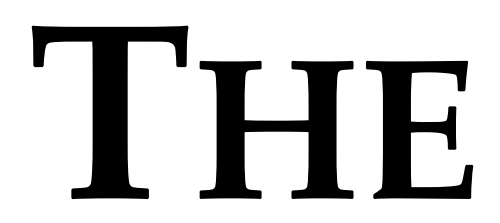

Problem 


\section{CHAPTER 1: INTRODUCTION}

\section{INTRODUCTION}

In the middle of the first decade of the 21st century, three Australian judges simultaneously found themselves in the midst of overwhelmingly long and complex civil litigation. In May 2006, Justice Ronald Sackville celebrated the 100th sitting day of the $C 7$ trial in the Federal Court of Australia by sharing banana and chocolate cakes (decorated with the letter ' $C$ ' for the Latin '100') with counsel, solicitors and court staff. ${ }^{1}$ At the same time, before Justice Robert Austin in the Supreme Court of New South Wales, the trial in ASIC $v$ Rich concerning the collapse of One.Tel had been underway for more than a year and a half, and the defendants were yet to commence their case. ${ }^{2}$ Meanwhile, in the Supreme Court of Western Australia, Justice Neville Owen was almost three years into the mammoth Bell Group trial, and would not hand down judgment for another two and a half years. ${ }^{3}$ The concurrence of these three immense cases turned the spotlight onto a species of extraordinarily time-consuming and complex case which Sackville J, in C7, labelled 'megalitigation'. ${ }^{4}$

In this thesis I ask how judges reconcile the aims of justice and efficiency when making procedural decisions in mega-litigation. For the purposes of this thesis, 'mega-litigation' means civil litigation between well-resourced (and generally multiple) parties involving many complex factual issues, with the stakes usually exceeding $\$ 100$ million and the trial often taking upwards of 50 days. ${ }^{5}$ While $C 7$, ASIC $v$ Rich and Bell Group are the paradigm examples of mega-litigation in Australia, they are not alone. ${ }^{6}$ Mega-litigation has become - and, I argue in Chapter

1 See 'Celebration', Sydney Morning Herald, 31 May 2006,

$<$ http://www.smh.com.au/news/cbd/doc-spuds-in-miners-

heart/2006/05/30/1148956345146.html?page=fullpage\#>. The judgment following the $C 7$ trial is Seven Network Ltd v News Ltd [2007] FCA 1062. The judgment following this trial is Australian Securities and Investments Commission v Rich (2009) 236 FLR 1. The judgment is Bell Group Ltd (in liq) v Westpac Banking Corporation (No 9) (2008) 39 WAR 1. Seven Network Ltd v News Ltd [2007] FCA 1062, [1].

This definition is developed in Chapter 3. Other examples of mega-litigation include Duke Group Ltd (in liq) v Pilmer (1998) 144 FLR 1; Idoport Pty Ltd v National Australia Bank Ltd [2002] NSWCA 271; Pacific Acceptance Corporation Ltd v Forsyth (1970) 92 WN (NSW) 29; Alstom Ltd v Yokogawa Australia Pty Ltd [2012] SASC 49; Australian Federation of Consumer Organisations Inc $v$ Tobacco Institute of Australia Ltd (1991) 98 ALR 670; Trade Practices Commission $v$ TNT Management Pty Ltd (1985) 6 FCR 1; Wingecarribee Shire Council v Lehman Brothers Australia Ltd (2012) 301 ALR 1; and the class action against the retail property group Centro before Gordon J in the Federal Court, which settled in May 2012. 
4, is likely to remain - a feature of the Australian litigation landscape. Responding to the challenges of mega-litigation is a priority for the justice system, for governments, and for the community.

Throughout this thesis, I argue there are several different objectives to which court procedure can be directed: doing justice between the parties; doing justice from the point of view of the public (referred to throughout the thesis as 'public justice'); achieving efficiency for the parties; and achieving efficiency for the public ('public efficiency'). ${ }^{7}$ The relationship between these different - and sometimes conflicting aims is a perennial theme of literature on civil procedure, ${ }^{8}$ and a constant challenge for judges in trial courts. The tension between those objectives can become acute in mega-litigation. Any single case of mega-litigation can monopolise a judge's time dozens, or even hundreds, of working days. The consequences for public efficiency are obvious: a large proportion of the publicly funded resources of the court system are devoted to a single dispute. There are also consequences for public justice: other litigants are forced to wait for their cases to be heard. From the public point of view, then, there is a strong argument that courts should seek to deal with mega-litigation as efficiently as possible. Efficiency is also desirable from the point of view of the parties, with legal bills in mega-litigation running into hundreds of millions of dollars, and disputes taking many years to finalise.

\footnotetext{
I expand on these concepts in Chapter 2.

See, eg, Jeremy Bentham, Principles of Judicial Procedure in John Bowring (ed), The Works of Jeremy Bentham Vol II (William Tait, 1843) 5, 8; Nick Armstrong, 'Making Tracks' in AAS Zuckerman and Ross Cranston (eds), Reform of Civil Procedure: Essays on 'Access to Justice' (Clarendon Press, 1995) 97; Chief Justice Murray Gleeson, 'The Judicial Method: Essentials and Inessentials' (2010) 9 The Judicial Review 377, 381; Sir Jack IH Jacob, 'Accelerating the Process of Law' in Sir Jack IH Jacob, The Reform of Civil Procedural Law (Sweet \& Maxwell, 1982) 91, 95-6; AAS Zuckerman, 'A Reform of Civil Procedure - Rationing Procedure Rather than Access to Justice' (1995) 22 Journal of Law and Society 155; Adrian AS Zuckerman, 'Justice in Crisis: Comparative Dimensions of Civil Procedure' in Adrian AS Zuckerman (ed), Civil Justice in Crisis (Oxford University Press, 1999) 3; Chief Justice John Doyle, 'The Machine of Justice Who is Driving It?' (2007) 28 Adelaide Law Review 7; Justice GL Davies, 'The Reality of Civil Justice Reform: Why We Must Abandon the Essential Elements of Our System' (2003) 12 Journal of Judicial Administration 155, 169; Alan Rose, 'The Model Judiciary - Fitting in with Modern Government' (1999) 4 The Judicial Review 323; Justice Kenneth Hayne, 'Aspects of Justice Reform' (Paper presented to Supreme and Federal Court Judges' Conference, Perth, 25-30 January 1998); Allan C Hutchinson, 'The Formal and Informal Schemes of the Civil Justice System: A Legal Symbiosis Explored' (1981) 19 Osgoode Hall Law Journal 473; Andrew Barker, 'Ideas on the Purpose of Civil Procedure' (2002) New Zealand Law Review 437; Colleen M Hanycz, 'More Access to Less Justice: Efficiency, Proportionality and Costs in Canadian Civil Justice Reform' (2008) 27 Civil Justice Quarterly 98; John Sorabji, ‘Late Amendment and Jackson's Commitment to Woolf: Another Attempt to Implement a New Approach to Civil Justice' (2012) 31 Civil Justice Quarterly 393.
} 
But efficiency cannot be the only goal of courts dealing with mega-litigation. The fundamental duty of a judge is to do justice according to law - that is, justice between the parties - in each case. ${ }^{9}$ Does a judge have any business considering the interests of the general public? Can a judge, when dealing with mega-litigation, ever compromise justice between the parties in order to achieve efficiency, or to improve access to justice for the general public? The answers to those questions depend both on fundamental beliefs about the role of judges, and on the practical reality of modern judicial life. Consider the following statement, by Austin J in ASIC $v$ Rich, about the central importance of doing justice between the parties. In a section of the judgment headed 'A fundamental principle is in issue', Austin J said:

The course of this trial raises a general question as to how far the court can and should go in abbreviating hearing time in a case which, as formulated and defended, is destined to cover huge and difficult evidentiary ground and to consume a large quantity of judicial resources. It seems to me that general issues about the allocation of judicial resources are not matters to be addressed by the trial judge, whose judicial duty is to hear and determine a case that has properly come before him or her, in accordance with established procedures. Manufacturing special procedures simply to deal with the length of the trial seems to me to raise a real risk of injustice, and so I have not done so. The fundamental principle to be observed by a judge who is required to manage and hear a long case, indeed any case, is to strive to do justice, procedural and substantive, between the parties according to law. ${ }^{10}$

Contrast this position with the view that a former Federal Court judge, the Honourable Ray Finkelstein QC, expressed in an interview conducted for the purpose of this thesis:

I do not believe in perfect justice. Society cannot afford it. ... There must be a trade-off between ... making sure that more money is not spent on a case than it is worth, and achieving a fair result. Now I understand that some people might say 'the more money you spend, ... the more likely you get a correct result.' But I think it is necessary to do a trade-off ... to sometimes adopt a very utilitarian approach. So, for example, I would limit dramatically, discovery ... If that meant documents that were relevant were not discovered, that is too bad. If parties can save millions of dollars in costs and in the process only one or two cases are badly decided the saving is justified. It is a perfectly utilitarian view. Do I sacrifice a few for the good of the many? Yes. Do I have any qualms about doing that? No. ${ }^{11}$

\footnotetext{
9 This duty is embodied, for example, in the judicial oath: a promise to do right to all manner of people, according to law.

$10 \quad$ Australian Securities and Investments Commission v Rich (2009) 236 FLR 1, 33 [67].

11 Interview with the Honourable Ray Finkelstein QC (Melbourne, 21 November 2012).
} 
This thesis explores the relationship between justice and efficiency, for both the parties and the public, in mega-litigation. In order to get to this point, I conduct an examination of the nature of mega-litigation, and of the tools available to judges to resolve tensions between justice and efficiency: theories, rules, principles and techniques. Much of the thesis is based on data collected in a series of interviews with judges who have experience in mega-litigation. ${ }^{12}$

Ultimately, my thesis is that judges reconcile the demands of justice and efficiency in mega-litigation by using a combination of highly involved case management, innovative procedures and well-informed expert intuition.

\section{SIGNIFICANCE AND LIMITS OF THE STUDY}

Mega-litigation has received some attention in academic literature. ${ }^{13}$ In addition, courts have produced reports and judicial practice guides on the management of complex commercial litigation. ${ }^{14}$ The existing literature focuses on the causes of mega-litigation, on strategies for managing mega-litigation (from the point of view of the lawyers involved as well as the court) and on possibilities for reform of court processes. This thesis makes three substantial contributions to this body of work. First, I develop and test a working definition of an identifiable species of litigation known as 'mega-litigation'. ${ }^{15}$ While the existing literature has identified various criteria associated with mega-litigation, in this thesis I use case examples and qualitative research to evaluate the relative significance of each criterion. Secondly, I confront the potential for tension between justice and efficiency in mega-litigation, and identify the practical means by which judges seek to reconcile this tension. The

12 The interviews are described below at 8-9, and in more detail in Appendix A.

13 Justice Ronald Sackville, 'Mega-Lit: Tangible Consequences Flow From Complex Case Management' (2010) Law Society Journal 47; Sir Anthony Clarke, 'The Supercase - Problems and Solutions: Reflections on BCCI and Equitable Life' (KPMG Forensic's Annual Law Lecture 2007, London, 29 March 2007); Justice Ronald Sackville, 'Mega-Litigation: Towards a New Approach' (2008) 8 The Judicial Review 89; Ross Cranston, 'Complex Litigation: The Commercial Court' (2007) 26 Civil Justice Quarterly 190; Michael Legg, Case Management and Complex Civil Litigation (Federation Press, 2011); Martin Meredith, 'Mega-Litigation Tales From Bell, C7 and BCCI - Lessons Still to be Learnt (Part 1)' (2013) (March) Law Society Bulletin 10; Martin Meredith, 'Mega-Litigation Tales From Bell, C7 and BCCI - Lessons Still to be Learnt (Part 2)' (2013) (April) Law Society Bulletin 26; Damian McGregor, ‘Outsourcing Justice? Courtappointed Examiners and the Management of Complex Litigation in the New South Wales Supreme Court' (2002) 11 Journal of Judicial Administration 116.

$14 \quad$ Judiciary of England and Wales, Report and Recommendation of the Commercial Court Long Trials Working Party (December 2007); Federal Judicial Center, Manual for Complex Litigation, Fourth (2004); Judicial Conference of the United States, Procedure in Anti-Trust and Other Protracted Cases (1951), reprinted in (1951) 13 Federal Rules Decisions 41, 65; Class Action and Electronic Trial Guide, Federal Court of Australia (2012) (Copy on file with author). See Chapter 3. 
literature alludes to, but does not fully engage with, this issue. ${ }^{16}$ The third contribution of this thesis is the result of the methodology chosen. I conducted a series of interviews with judges who have presided over mega-litigation. This methodology - relatively unusual in legal research ${ }^{17}$ - enables me to provide a previously unavailable window into the world of the mega-litigation judge.

I do not set out, in this thesis, to prescribe what judges should do in mega-litigation, nor to set an agenda for law reform. Rather, I seek to record and analyse the way judges in fact deal with mega-litigation, especially their perceptions of the relationship between justice and efficiency in mega-litigation. The insights provided in this thesis can inform debates, at an academic and policy level, about how to deal with mega-litigation in the future. Although my intention was not to make normative claims about the best way of dealing with mega-litigation, some strong conclusions emerge from the analysis and these have implications for how, and by whom, mega-litigation should be managed. Most significantly, it is clear that the management of mega-litigation depends, to a large extent, on characteristics personal to the individual judge: personality, skill, experience and attitude. In the conclusion to this thesis I consider the ramifications of this finding for judicial recruitment and education and allocation of mega-litigation matters.

This thesis is about the role of the judge in mega-litigation. There are, of course, other players in mega-litigation. Most prominent among them are the parties themselves, and their lawyers. Less directly, the Executive government of each jurisdiction plays a role in funding mega-litigation, both through the court system generally and through one-off payments to deal with particular cases. ${ }^{18}$ The general community has a stake in mega-litigation, given the amount of taxpayer funds it consumes, and its effect on access to the courts. I touch on each of these players in

16 See, eg, Legg, above n 13, Chapter 10; Sackville, 'Mega-Litigation: Towards a New Approach', above n 13, 97, 102; Justice Steven Rares, 'What Is a Quality Judiciary?' (2011) 20 Journal of Judicial Administration 133, 143.

17 Empirical research in law is certainly not unknown but remains unusual. Empirical studies which share some features of the methodology adopted in this thesis include Sharon Roach Anleu and Kathy Mack, 'Magistrates' Everyday Work and Emotional Labour' (2005) 32 Journal of Law and Society 590; Caroline Sage and Ted Wright with Carolyn Morris, Case Management Reform: A Study of the Federal Court's Individual Docket System (Law and Justice Foundation, June 2002); Gabrielle Appleby, The Constitutional Role of the Solicitor-General: An Historical, Legal and Lived Portrait (PhD thesis, University of Adelaide, 2012); Geraldine Mackenzie, How Judges Sentence (Federation Press, 2005).

18 For example, the Western Australian government provided $\$ 4.2$ million for the Bell Group appeal (discussed in Chapter 4 at 43), while the Victorian government spent $\$ 4$ million to construct a special courtroom for the trial of a class action arising from the Black Saturday bushfires: Supreme Court of Victoria, Annual Report 2012-13, 32. 
this thesis, but almost exclusively from the perspective of the judge. At times, I am critical of the conduct of lawyers and parties in mega-litigation. A study of megalitigation from the perspective of these players might place their conduct in a different light. This may be a fruitful area for further research.

In examining the role of judges in mega-litigation, this thesis spends minimal time considering the place of alternative dispute resolution in bringing mega-litigation to an end. Many mega-litigation matters go to alternative dispute resolution and some settle. ${ }^{19}$ In the meantime, many hours of court time may be spent managing those matters. Therefore, even if a matter settles following alternative dispute resolution, the court will have had to engage with the questions considered by this thesis.

In this thesis I consider only civil litigation. There are, of course, long and complex criminal cases that place enormous demands on courts. However, there are fundamental differences between the role of the court in a criminal case and in a civil claim between individuals or corporations. The equation of justice and efficiency plays out differently when the interests of the State are pitched against those of an individual. The extent to which the court can dictate the way in which the case is run is different when the liberty of an individual is at stake. Different procedural questions altogether arise when the function of fact-finding is performed by a jury. The criminal equivalent of mega-litigation may be worthy of study, but it is beyond the scope of this thesis.

\section{MethodOLOGy AND STRUCTURE}

This thesis combines qualitative methods with more familiar legal research methods. The relationship between justice and efficiency in civil procedure is analysed using theoretical ${ }^{20}$ and doctrinal ${ }^{21}$ methods. The nature of mega-litigation, and the ways in which courts deal with mega-litigation, are examined using data collected in a series of qualitative interviews. ${ }^{22}$ This interview data is supplemented by material from other sources: journal articles, books, judgments, and speeches. ${ }^{23}$

The interview data is drawn from semi-structured interviews with 16 judges who

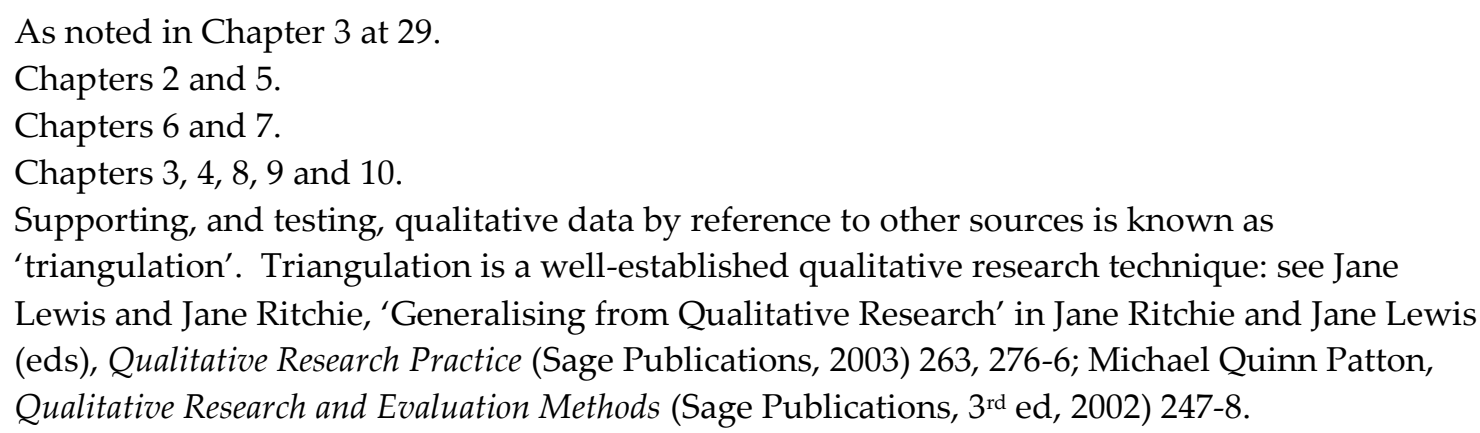


have experience in mega-litigation, as either trial judge, case managing judge (or both) or head of jurisdiction at a time when a mega-litigation case was being heard. ${ }^{24}$ This group represents a significant proportion of the judges who have presided over mega-litigation in Australia. I chose to conduct interviews because I believed that the material available in law reports, journals and public speeches did not provide a full record of the task of the judge in mega-litigation. The analysis of the interview data is based on a postpositivist ontological assumption that, while an objective reality exists, each participant's perception of their role is influenced by their experiences and personality. ${ }^{25}$

The thesis is divided into three parts. Part I (Chapters 1, 2, 3 and 4) sets up the problem with which this thesis is concerned, and introduces the abstract and definitional concepts that frame the discussion in Parts II and III. I begin, in Chapter 2 , by explaining an idea underlying much of the analysis in the thesis: ${ }^{26}$ civil procedure has multiple objectives. I call these objectives 'justice between the parties', 'public justice', 'party efficiency' and 'public efficiency'. In Chapter 3 I address the definitional question of what I mean by 'mega-litigation'. I arrive at a flexible, multifactorial definition which is suitable for the purposes of this thesis. Chapter 4 explains why mega-litigation is a significant problem. Mega-litigation places enormous burdens 'not only on the parties, but on the court system and, through that system, the community.' ${ }^{27}$ By analysing the factors that cause megalitigation, I argue that it is likely to continue to occur in the future. Consequently, it is important that courts devise ways of dealing with mega-litigation efficiently. This does not mean, however, that courts should abandon the pursuit of justice in these cases. The tension between the various aims of procedure comes into sharp focus in the mega-litigation context.

In Part II of the thesis I look to academic literature and law in search of solutions to the problem of reconciling justice and efficiency in civil procedure generally, rather than in mega-litigation. There is a wide range of material that does not address mega-litigation specifically, but is applicable to all civil litigation. Chapter 5 deals, briefly, with some prominent theories on the relationship between justice and efficiency in court procedure: those of Adrian Zuckerman, Richard Posner, Ronald Dworkin and Robert Summers. Chapter 6 provides a brief history of the general

\footnotetext{
24 For more information on the interview methods, see Appendix.

25 Miles and Huberman take a similar ontological position: Matthew B Miles and A Michael Huberman, Qualitative Data Analysis (Sage Publications, $2^{\text {nd }}$ ed, 2004), 4.

26 Introduced earlier, at 4-5.

27 Seven Network Ltd v News Ltd [2007] FCA 1062, [1] (Sackville J).
} 
approaches to Anglo-Australian civil procedure over the last 150 years. This history reveals a series of shifts in thinking about the aims of civil procedure: from a formalistic, rule-based approach, to an emphasis on doing justice between the parties at all costs, to the modern case management approach which gives judges a far greater role than they had in the past, and prioritises the aims of efficiency and public justice. Chapter 7 brings this history into the modern Australian context, by examining the most significant developments in Australian civil procedure over the last 20 years and explaining the constitutional context within which Australian courts operate. By the end of Part II it will be apparent that, while the tension between the different aims of civil procedure has presented constant challenges for judges and scholars, there is no established solution to the problem.

Against this background, Part III (Chapters 8, 9 and 10) draws on the qualitative interview data in order to determine how judges actually deal with tensions between justice and efficiency in mega-litigation. In Chapter 8 I identify four characteristics that typify the approach of the typical mega-litigation judge. The mega-litigation judge is active (rather than passive) in managing all aspects of the case; is flexible in their approach to procedure; is creative in devising new ways of dealing with megalitigation; and conducts the hearing in a way which is fair to the parties. I also argue that each judge's personality and experience have a major influence on the way they deal with mega-litigation. Chapter 9 demonstrates the translation of these characteristics into practice by providing an overview of the procedural techniques used in mega-litigation. These include modified approaches to procedures such as discovery and definition of issues; limiting the amount of material the parties put before the court; and controlling the way in which the case is presented. Building on this information, Chapter 10 draws together the themes and information introduced in earlier chapters, in order to answer the central question of this thesis: how do judges in mega-litigation reconcile the aims of justice and efficiency? I consider what the interview data reveals about the significance of the theories introduced in Chapter 5, and the case law and rules discussed in Chapters 6 and 7, to procedural decision-making in mega-litigation. The impression emerging from the interviews is that these sources can be helpful, but are rarely determinative; they leave the judge with a wide margin of discretion. In other words, the sources introduced in Part II of this thesis do not answer the question this thesis poses. Instead, the interview data suggests three answers to my question. First, judges in mega-litigation reconcile the demands of justice and efficiency by developing innovative procedures that further the ends of both justice and efficiency. Secondly, by engaging in active case management, judges ensure a sharp focus on the real issues in dispute, thus 
improving efficiency without compromising justice. Thirdly, when tension between justice and efficiency arises, it is resolved by highly informed expert intuition. 


\section{Chapter 2: Justice And Efficiency as Aims of Civil Procedure}

\section{INTRODUCTION}

[J]ustice is a fine word, but it is sometimes difficult to say exactly what one means by it. ${ }^{1}$

This thesis asks how judges reconcile the aims of justice and efficiency in megalitigation. Before going further, it is necessary to explain what I mean by 'justice' and 'efficiency'. These terms are, of course, value-laden and contestable. The purpose of this chapter is to frame the issues I explore in this thesis. To this end, the chapter provides an analysis of the foundational concepts used in the thesis. For the purposes of this thesis, I adopt relatively uncontroversial, practical concepts of 'justice' and 'efficiency' as aims of civil procedure.

The aims of civil procedure can vary depending on the perspective from which we view the justice system. Nick Armstrong contrasts two different models of civil justice system:' the 'dispute resolution' model, which prioritises the private interests of the parties to litigation; and the 'policy implementation' model, which 'recognises a wider public interest' ${ }^{\prime 3}$ in civil litigation. 'Justice' for the parties may not be the same as 'justice' for the general public. This chapter considers justice and efficiency from both points of view: that of the parties to an individual case, and that of the general public. Accordingly, this chapter develops four concepts which I will use, throughout the thesis, to discuss the aims of civil procedure: 'justice between the parties', 'public justice', 'party efficiency' and 'public efficiency'.

Section II of the chapter deals with the concept of justice, starting with the meaning of 'justice' for the parties to a case. Starting from the position that justice means giving effect to the substantive law, I expand the concept of justice for the parties to include the factors of cost, time and procedural justice. From the public point of view, it is important that court decisions give effect to the substantive law; but justice for the public involves, in addition, securing access to justice for the community.

Section III of this chapter explains the concept of efficiency. For the purposes of this thesis, efficiency for the parties means minimising the time and cost that the parties

Agatha Christie, Death in the Clouds (1935) Chapter 15.

Nick Armstrong, 'Making Tracks' in AAS Zuckerman and Ross Cranston (eds), Reform of Civil Procedure: Essays on 'Access to Justice' (Clarendon Press, 1995) 97.

Ibid 99. 
incur. The public concern with efficiency in court procedure, in contrast, focuses on the responsible use of public resources.

Having defined these concepts, in Section IV I briefly consider some of the ways in which these different perspectives on justice and efficiency in civil procedure interact with one another. The purpose of the chapter is to establish the concepts of justice and efficiency which will be used throughout this thesis; and to introduce some ideas about the way these concepts can either conflict with or complement each other.

\section{JUSTICE}

It is axiomatic that civil procedure should aim to achieve justice. My starting point is that 'justice', as an aim of civil procedure, means giving effect to the substantive law. This is a conventional position. For Jeremy Bentham, the 'only defensible object' of the 'adjective' (procedural) branch of law was 'the maximization of the execution and effect given to the substantive branch of the law.' ${ }^{4}$ Proceeding from this starting point, in this section I consider what justice, as an aim of civil procedure, means for the parties to a dispute and for the public.

\section{A Justice Between the Parties}

My starting point is that justice is done if the court gives effect to the substantive law governing the dispute between the parties to a case. For the parties, justice therefore entails applying the relevant law to the true facts of the case. But even if considering only the interests of the parties, this conception of justice seems incomplete. Adrian Zuckerman argues that time and cost, as well as the accuracy of the decision, are dimensions of justice. ${ }^{5}$ Cost and time might appear relevant to efficiency, rather than justice. But if justice means giving effect to the substantive legal rights of the parties, it is not enough for the court to determine what those rights are, regardless of the cost or delay involved. That determination must come at such a time as to be of utility, and at a cost which is reasonable in the context of the matter. A judgment might be correct in fact and law, yet come too late to rectify the wrong that has been

$4 \quad$ Jeremy Bentham, Principles of Judicial Procedure in John Bowring (ed), The Works of Jeremy Bentham Vol II (1843) 5, 6. See also Robert G Bone, 'Making Effective Rules: The Need for Procedure Theory' (2008) 61 Oklahoma Law Review 319, 329.

5 Adrian AS Zuckerman, 'Justice in Crisis: Comparative Dimensions of Civil Procedure' in Adrian AS Zuckerman (ed), Civil Justice in Crisis (Oxford University Press, 1999) 3, 3; Adrian Zuckerman, 'Litigation Management Under the CPR: A Poorly-Used Management Infrastructure' in Deirdre Dwyer (ed), The Civil Procedure Rules Ten Years On (Oxford University Press, 2009) 89, 90; Adrian Zuckerman, Zuckerman on Civil Procedure: Principles of Practice (Sweet and Maxwell, $2^{\text {nd }}$ ed, 2006), 3-6. Zuckerman's three-dimensional view of justice is discussed in depth in Chapter 5 at 65-8. 
done. ${ }^{6}$ For example, a plaintiff who has suffered personal injury might have to suffer years of hardship before being compensated. ${ }^{7}$ Likewise, excessive cost can undermine the efficacy and fairness of judicial proceedings. It is not uncommon for the legal costs incurred by the parties to approach or even exceed the amount at stake in the claim. Justice Geoffrey Davies has observed:

A system which yields a fair result in accordance with legal rights and a procedure which is fair between the parties, but at a cost which a disputant of average means cannot afford or which is grossly disproportionate to the amount involved, will not be fair. ${ }^{8}$

A plaintiff may make out their claim yet lose money as a result of litigation. A defendant may gain a judgment wholly in their favour, yet be left with a very large costs bill. A court that allows litigants to run up costs to such levels is 'killing the parties with kindness'. ${ }^{9}$ A party who obtains a judgment in their favour yet is left with a costs bill disproportionate to the amount in dispute has arguably not had their substantive legal rights upheld in any meaningful way. In short, cost and time cannot be disentangled from the aim of giving effect to the substantive law.

So far we have focused on achieving a just outcome between the parties. The justice of the court process is also an aspect of justice between the parties. ${ }^{10}$ A body of empirical research suggests that litigants' satisfaction with the justice system depends on their perceptions of the fairness of the process as well as the outcome. ${ }^{11}$

6 See Zuckerman, Zuckerman on Civil Procedure, above n 5, 11; AAS Zuckerman, 'Quality and Economy in Civil Procedure: The Case for Commuting Correct Judgments for Timely Judgments' (1994) Oxford Journal of Legal Studies 353, 360. Zuckerman's argument that time is a 'dimension' of justice is explained in Chapter 5 of this thesis, at 66.

7 See Thomas W Church, 'A Consumer's Perspective on the Courts' (Second Annual Oration in Judicial Administration, delivered on 31 October 1990 at Melbourne University), 5-6.

$8 \quad$ Justice GL Davies, 'Fairness in a Predominantly Adversarial System' in Helen Stacy and Michael Lavarch (eds) Beyond the Adversarial System (Federation Press, 1999) 102, 109.

$9 \quad$ Chief Justice JJ Spigelman, 'The "New Public Management" and the Courts' (2001) 75 Australian Law Journal 748, 749-50, quoting Lord Hoffmann in Piglowska v Piglowski [1999] 1 WLR 1360, 1373.

10 The theoretical underpinnings of the importance of procedural justice are discussed in Chapter 5 (at 75-80), with reference to the work of John Rawls and Robert S Summers.

11 John Thibaut and Laurens Walker, Procedural Justice (Hillsdale, 1975); Laurens Walker, E Allan Lind and John Thibaut, 'The Relation Between Procedural and Distributive Justice' (1979) 65 Virginia Law Review 1401; Tom R Tyler, 'Procedural Justice and the Courts' (2007) 44 Court Review 26; Tania Matruglio, Plaintiffs and the Process of Litigation: An Analysis of the Perceptions of Plaintiffs following their Experience of Litigation (Law Foundation of NSW, Sydney, 1994); Marketshare Pty Ltd, Community and Client Perceptions of the Queensland Court System (1991) cited in Cairns, 'Lord Woolf's Report on Access to Justice: An Australian Perspective' (1997) 16 Civil Justice Quarterly 98, 101; E Allan Lind et al, 'In the Eye of the Beholder: Tort Litigants' 
One study, for example, found there was no correlation between, on the one hand, the outcome, cost or duration of a case and, on the other, litigants' perceptions of the fairness of the process. ${ }^{12}$ Another found that litigants' overall satisfaction with the litigation process was influenced more by their perceptions about the fairness of the process than by the outcome of the case. ${ }^{13}$ Therefore, when considering justice between the parties, not only the outcome, but also the means of reaching the outcome is important.

If we add this to our concept of justice from the parties' point of view, we are left with the idea that justice between the parties involves the court reaching an accurate resolution of the real issues in dispute, at a reasonable cost, without undue delay, and following a fair process. I will refer to this concept, throughout the thesis, as 'justice between the parties'.

Note that this concept is not subjective. Justice between the parties does not involve an inquiry into what the parties desire. This will become significant later in the thesis, when exploring the concept of party control of proceedings. ${ }^{14}$ A short example will be sufficient to make the point at this stage. Imagine that, at the start of trial, a party wishes to tender a bundle of thousands of documents, saying that they are all relevant to the issues in dispute. The judge refuses to accept the tender, instead allowing the party to tender documents individually if and when they become relevant to submissions or evidence being received. In this situation, there has been no compromise in the quality of justice between the parties; the court will have all the documents it needs in order to determine the real issues. All that has been lost is the parties' ability to decide how the case will be run. This point will be reiterated throughout the thesis: doing justice between the parties does not necessarily mean doing what the parties want.

\section{B Public Justice}

The concept of justice outlined above focuses narrowly on the interests of the parties to a case. What happens if we broaden our view to ask what justice means for other litigants and for the community in general? The starting point can, once again, be that justice means giving effect to the substantive law. From the public perspective, however, we must take into account the legal rights of everybody within the

Evaluations of Their Experiences in the Civil Justice System' (1990) 24 Law and Society Review 953.

12 Lind, above n 11, 968-70.

$13 \quad$ Matruglio, above $\mathrm{n} 11$.

$14 \quad$ Chapter 6 at 87-8 and 90. 
community; not just the rights of the parties to a particular case. Giving parties A and $B$ the fullest possible opportunity to present their case, without regard to the proportion of court resources that their case consumes, might achieve justice between $\mathrm{A}$ and $\mathrm{B}$. But it might also mean that litigants $\mathrm{C}$ and $\mathrm{D}$ face a long wait for their case to go to trial, thus undermining the utility of the judgments $C$ and D ultimately receive. Meanwhile, potential plaintiffs $\mathrm{E}$ and $\mathrm{F}$, whose legal rights have been violated, decide that court waiting lists are so long that it is not worth litigating at all. A party-centred view of justice fails to take into account the fact that doing justice to $\mathrm{A}$ and $\mathrm{B}$ might mean that the legal rights of $\mathrm{C}, \mathrm{D}, \mathrm{E}$ and $\mathrm{F}$ are compromised. On this view, a reduction in the procedural resources allocated to A and B can be justified in order to provide justice to C, D, E and F. To put it pithily, 'a party is entitled to his day in court but not to someone else's day in court.' 15

Similarly, if litigation becomes an extremely expensive exercise, the courts may become inaccessible to many potential litigants. ${ }^{16}$ It is in this context that authors such as Zuckerman argue that compromises in the quality of justice in an individual case are sometimes necessary to achieve justice in a wider sense:

To be able to seek redress for wrongs, citizens have to have access to the courts. However, a system of procedure that is so expensive as to place litigation beyond the reach of most citizens may be said to deny justice to the majority of the population. ... [I]t is by no means clear that it is better to return a few highly accurate judgments than to render a multitude of judgments of rougher accuracy. ${ }^{17}$

In short, justice from a 'public' point of view must include consideration of access to justice. ${ }^{18}$ A system does not achieve the aim of giving effect to the substantive law if it delivers accurate judgments to a small number of parties but provides no redress at all in the majority of cases.

$15 \quad$ United Motors Retail Ltd v Australian Guarantee Corporation Ltd (1991) 58 SASR 156, 158 (King CJ).

16 See Productivity Commission, Access to Justice Arrangements: Draft Report (2014) Chapter 3.

17 Zuckerman, 'Quality and Economy in Civil Procedure', above n 6, 361 (citations omitted, emphasis added). See also Zuckerman, 'A Reform of Civil Procedure - Rationing Procedure Rather than Access to Justice' (1995) 22 Journal of Law and Society 155, 161; Zuckerman, 'Justice in Crisis', above n 5, 9; Zuckerman, 'Litigation Management Under the CPR', above n 5, 99.

18 See, eg, Justice DA Ipp, 'Opportunities and Limitations for Change in the Australian Adversary System' in Helen Stacy and Michael Lavarch (eds), Beyond the Adversarial System (Federation Press, 1999) 68, 75-9; JA Jolowicz, On Civil Procedure (Cambridge University Press, 2000), 71; Neil Andrews, 'The Adversarial Principle: Fairness and Efficiency: Reflections on the Recommendations of the Woolf Report' in AAS Zuckerman and Ross Cranston (eds), Reform of Civil Procedure: Essays on 'Access to Justice' (Clarendon Press, 1995) 169, 175. 
There is an important caveat to this analysis. To this point we have assumed that only $\mathrm{A}$ and $\mathrm{B}$ have an interest in the outcome of their litigation. But there is a broader public interest in the accurate resolution of legal disputes. ${ }^{19}$ For one thing, civil proceedings provide an opportunity for judges 'to perform their function of interpreting, clarifying, developing and ... applying the law.' ${ }^{20}$ Furthermore, courts have a 'pivotal role' in 'maintaining the rule of law'. ${ }^{21}$ Sir Gerard Brennan expands on this point:

The settlement of disputes by legal process is a fundamental function of government in a society under the rule of law. If the function is not performed, the law is not applied and the festering sore of injustice spreads the infection of self-help. Power is then unrestrained by law. Peace and order are at risk and, sometimes, tragedy may be the consequence. Laws that are put on the statute book mock the integrity of the political process unless the beneficiaries of those laws can enforce them. ${ }^{22}$

Zuckerman makes a similar point:

Law enforcement, whether civil or criminal, transcends the interests of the immediate parties. In a society governed by the rule of law, we all have an interest in rights being respected and in wrongs being remedied. The surest way of undermining good social order is to allow infringements of rights to go without redress. Where there is no redress for wrongs there is no value to rights and no reason to behave according to the law. ${ }^{23}$

For this reason, it is in the interests of the whole community that courts reach the right decisions. There is clearly a public interest in maintaining the institutional legitimacy of courts, as bodies that give effect to legal rights. But the point at which a failure in court procedure leads to a breakdown in public order is, surely, a worst case scenario, likely to result only from a systematic disregard for accuracy in adjudication. Further, as the quotes above highlight, the rule of law is as likely to suffer from widespread denial of access to justice as from a failure by courts to reach correct decisions.

\footnotetext{
19 See Michael King et al, Non-Adversarial Justice (Federation Press, $2^{\text {nd }}$ ed, 2014) 11-12.

20 Jolowicz, above n 18, 71.

$21 \quad$ Justice Ronald Sackville, 'Reforming the Civil Justice System: The Case for a Considered Approach' in Helen Stacy and Michael Lavarch (eds), Beyond the Adversarial System (Federation Press, 1999) 34, 42-3.

22 Sir Gerard Brennan, 'Key Issues in Judicial Administration' (1996) 6 Journal of Judicial Administration 138, 140. See also Jolowicz, above n 18, 71. 
My position is that the public in general does have an interest in courts determining disputes according to law. For this reason, the public and party views of justice will sometimes converge. However, there is a powerful argument that access to justice is crucial to achieving justice from a public point of view. From this point of view it may sometimes be 'just' to compromise justice between the parties in a particular case for the sake of justice for the community.

\section{EFFICIENCY}

In this chapter so far, we have seen that our assessment of 'justice' depends on whether we take the point of view of the parties or that of the public. The situation is similar when we attempt to define 'efficiency'; what is efficient for the parties may not be so from the public perspective. ${ }^{24}$

\section{A Party Efficiency}

Efficiency for the parties to a case can be explained briefly. For the purposes of this thesis, 'efficiency' from a party perspective means minimising the cost and time spent resolving the dispute. These two aspects of efficiency may conflict. The fastest way of resolving a dispute may not always be the cheapest. For instance, while intensive judicial case management might hasten the resolution of a matter (whether by trial or settlement), it may also increase the labour required and, therefore, the costs incurred by the parties. ${ }^{25}$ In general, however, consideration of efficiency from the perspective of the parties will involve a relatively straightforward enquiry about the costs incurred by the parties.

Earlier in this chapter, ${ }^{26} \mathrm{I}$ argued that cost and time are aspects of doing justice between the parties. This is because excessive cost and delay may render a determination of legal rights practically meaningless. But even if cost and delay do

24 Economic analysis has developed specific technical meanings for the word 'efficiency'. These meanings will, in general, not be adopted in this thesis except where necessary to explain aspects of economic theory. Briefly, a situation is 'Pareto efficient' when it is impossible to change the situation so as to make one person better off and no person worse off. Because Pareto efficiency hardly ever occurs in the real world, economists often find it more useful to use the concept of 'Kaldor-Hicks efficiency'. Using the Kaldor-Hicks approach, one situation is superior to another if the gains to some individuals as a result of the first situation are great enough to compensate other individuals for the losses they suffer as a result of the situation. See, eg, Judge Richard A Posner, Economic Analysis of Law (Wolters Kluwer, $7^{\text {th }}$ ed, 2007) 12-3.

25 See Craig Down, 'Crying Woolf? Reform of the Adversarial System in Australia' (1998) 7 Journal of Judicial Administration 213, 220; IR Scott, 'Caseflow Management in the Trial Court' in AAS Zuckerman and Ross Cranston (eds), Reform of Civil Procedure: Essays on 'Access to Justice' (Clarendon Press, 1995) 1, 22; Australian Law Reform Commission, Managing Justice: A Review of the Federal Civil Justice System, Report No 89 (2000), [4.20]. 
not reach this level, efficiency is still desirable from the parties' point of view. A plaintiff may have a claim that is worth pursuing even if it costs a lot of money and takes a long time, but they would rather it took less money and time.

\section{B Public Efficiency}

In this thesis, the term 'public efficiency' will be used to refer to the use of the resources of the civil justice system. An efficient civil justice system will produce its outputs (finalised cases) at minimal cost to the public and at maximum speed.

In Sali v SPC Ltd, ${ }^{27}$ Brennan, Deane and McHugh JJ observed that:

What might be perceived as an injustice to a party when considered only in the context of an action between parties may not be so when considered in a context which includes the claims of other litigants and the public interest in achieving the most efficient use of court resources. ${ }^{28}$

We have already observed that doing justice between the parties may cause injustice to other litigants by denying them access to justice. But the passage in italics above raises quite a different point: the public interest in the way in which public resources are used. In my taxonomy of justice and efficiency for the parties and the public, this aspect of the public interest falls into the category of 'public efficiency'. Every member of the public has an interest in the way courts - as taxpayer-funded institutions - are run, for the same reason that we all have an interest in preventing social security fraud, or monitoring the travel expenses of members of parliament. Public money spent on courts is money not spent elsewhere.

This aspect of the public interest is distinct from that discussed above under the heading 'public justice'. We could say it is 'unjust' for taxpayers' money to be used on elaborate, time-consuming court procedures. But to say this is to invoke a colloquial concept of 'justice' that is quite different from 'justice' in the sense of giving effect to the substantive law. For this reason, throughout this thesis I maintain a distinction between 'public justice' and the use of public resources. The latter will, in this thesis, be relevant to public efficiency.

(1993) 116 ALR 625. This case is discussed in detail in Chapter 7.

Sali v SPC Ltd (1993) 67 ALJR 841, 844 (emphasis added). This passage quoted with apparent approval by French CJ in Aon Risk Services Australia Ltd v Australian National University (2009) 239 CLR 175, 190 [26]. 
Unavoidably, courts rely upon taxpayer funding. ${ }^{29}$ This funding will never be unlimited. As important as a justice system is to a civilised society, there will always be other, equally deserving, claims on the public purse. Zuckerman argues that citizens are not

entitled to claim the best possible court adjudication system regardless of how much it costs. It does not follow that just because we have a legitimate claim that the state should protect our rights we also have a legitimate claim to the best possible law enforcement system regardless of expense. As a citizen, I am no more entitled to the best possible system of justice than I am to the best possible health treatment.

Since public resources are limited we can only demand such civil enforcement services as can reasonably be afforded by the taxpayers. ${ }^{30}$

Ronald Dworkin agrees there are limits to what governments can be expected to invest in the court system. Notwithstanding the importance he places on giving effect to legal rights, ${ }^{31}$ Dworkin rejects the notion that a society must put the aim of achieving the highest possible level of accuracy in litigation 'lexically prior to all other needs':

a society governed by that constraint ... could never devote public funds to amenities like improvements to the highway system, for example, so long as any further expense on [court] process could improve its accuracy. Our own society plainly does not observe that stricture, and most people would think it too severe. ${ }^{32}$

Other commentators on procedural law, including judges writing extra-curially, have likewise noted the influence of limited public resources on debates about procedural reform. ${ }^{33}$ Judges making procedural decisions have often expressed an

29 This is not a bad thing. Government funding has the obvious benefit of preserving judicial independence.

30 Zuckerman, 'Litigation Management Under the CPR', above n 5, 91. Zuckerman makes similar arguments elsewhere: Zuckerman, 'A Reform of Civil Procedure', above n 17, 162; Zuckerman, 'Quality and Economy in Civil Procedure', above n 6, 354.

$31 \quad$ See, eg, Ronald Dworkin, Taking Rights Seriously (Gerald Duckworth, 1978). Dworkin's contribution to the debate on justice and efficiency in procedure is discussed in Chapter 5.

32 Ronald Dworkin, A Matter of Principle (Clarendon Press, 1986), 84. While Dworkin is dealing here with the criminal process, the point holds for civil process. If anything, it is harder to justify devoting funds to increasing the accuracy of the civil process, in which liberty is not at stake.

33 See, eg, Stephen Parker, 'Islands of Civic Virtue? Lawyers and Civil Justice Reform' (1997) 6 Griffith Law Review 1, 2; Justice DA Ipp, 'Reforms to the Adversarial Process in Civil Litigation Part 1' (1995) 69 Australian Law Journal 705, 721; Geoffrey Hazard, 'Rationing Justice' (1965) 8 Journal of Law and Economics 1, 4; Davies, above n 8, 110; Justice Douglas Drummond, 'Towards 
awareness of the effect of their decisions on resource allocation. For example, one Federal Court judge has observed:

Courts are publicly funded institutions. ... The judges who preside over them have a duty, consistently with their primary duty to administer justice, to do their utmost to prevent waste of public time and money. ${ }^{34}$

Taking a broader, 'public' view of efficiency has at least two consequences for the analysis in this thesis. First, a conclusion that governments need to provide more funding to courts may be neither realistic nor helpful. ${ }^{35}$ Funding will always be limited. Taxes cannot be raised exponentially to meet the needs of the justice system. Secondly, because resources are finite, any step that commits judicial resources to a particular dispute makes those resources unavailable to other litigants within the system. So, for example, greater judicial involvement in individual cases may inevitably lead to delays for other matters within the system, because only a limited number of judicial hours are available.

One might think that there will be little difference between what is efficient for the parties and what is efficient for the public. Surely, from both points of view, it is better that cases be dealt with quickly and cheaply? This is not necessarily the case. Some commentators have suggested that a certain amount of inefficiency for the parties to individual cases can be good for the efficiency of the system as a whole. ${ }^{36}$ Reducing the cost of litigation to the parties may increase demand for litigation and, in turn, increase delays across the whole system. ${ }^{37}$ Similarly, measures aimed at reducing delay in individual cases might encourage more litigation of relatively minor claims and thus increase pressure on the system. ${ }^{38}$ Cost and delay can in fact operate as a 'rationing' device, determining which cases are heard and which never get to court. ${ }^{39}$

a More Compliant Judiciary? - Part 1' (2001) 75 Australian Law Journal 304, 321; Sir Anthony Mason, 'The Courts as Community Institutions' (1998) 9 Public Law Review 83, 84.

$34 \quad$ EI Du Pont De Nemours \& Co v Commissioner of Patents (1987) 16 FCR 423, 424.

35 See Ipp, 'Reforms to the Adversarial Process', above n 33, 706.

36 See, eg, Samuel R Gross, 'The American Advantage: The Value of Inefficient Litigation' (1986) 85 Michigan Law Review 734; Posner, above n 24, 612.

37 See Hugh Gravelle, 'Regulating the Market for Civil Justice' in AAS Zuckerman and Ross Cranston (eds), Reform of Civil Procedure: Essays on 'Access to Justice' (Clarendon Press, 1995) 279, 289.

38 Posner, above n 24, 625.

39 See, eg, Chief Justice John Doyle, 'Imagining the Past, Remembering the Future - the Demise of Civil Litigation' ( $8^{\text {th }}$ Gerard Brennan Lecture, delivered at Bond University, 24 June 2011), 5. This analysis puts to one side questions of justice. It may be 'efficient' for meritorious yet 


\section{Relationship BetWeEn PARTy AND Public Perspectives ON Justice AND}

\section{EFFICIENCY}

In this chapter so far, I have sorted the aims of civil procedure into four groups: justice between the parties; public justice; party efficiency; and public efficiency. I have explained how each aim can be invoked as a legitimate aim of civil procedure. Throughout the thesis, I will use these four aims of civil procedure to describe and explain judicial and academic attitudes to procedure. At this point, some brief observations about the way in which these aims interact will set the scene for the analysis that follows.

The discussion of civil procedural law in Australia in Chapter 7, and the analysis of interviews with judges in Chapters 8, 9 and 10, will demonstrate that the aims of civil procedure identified in this chapter are all accepted within the contemporary approach to civil procedure. In particular, the aims of public justice and public efficiency have assumed a degree of prominence that they did not always have. ${ }^{40}$

An influential view throughout much of the 20th century was that procedure should aim to do justice between the parties, with other aims - if acknowledged at all being very much subservient to this aim. ${ }^{41}$ For example, Isaacs J described 'practice and procedure' as

mere formal machinery for bringing the claims and defences of parties before the Court in order that they may be determined justly in accordance with law. ${ }^{42}$

A corollary of this emphasis on doing justice between the parties is that some cost and delay is inevitable if justice is to be done. Writing extrajudicially about the danger of imposing performance measurement on courts, New South Wales Chief Justice James Spigelman said that '[s]ome things take time: justice is one of them': ${ }^{43}$

One characteristic of our administration of justice is its inefficiency when compared with some other systems of decision-making. There is no doubt that a

minor claims to be kept out of court. Yet this position ignores the injustice of allowing breaches of legal rights to go unremedied.

$40 \quad$ See especially Aon Risk Services Australia Ltd v Australian National University (2009) 239 CLR 175 and Expense Reduction Analysts Group Pty Ltd v Armstrong Strategic Management and Marketing Pty Ltd (2013) 250 CLR 303, in which the High Court expressly acknowledges the importance of factors beyond the interests of the parties. These cases are discussed in Chapter 7 .

41 See the discussion in Chapter 6 Section III.

42 Shannon $v$ Lee Chun (1912) 15 CLR 257, 265. For similar views, see GSA Industries Pty Ltd $v$ NT Gas Ltd (1990) 24 NSWLR 710, 714 (Kirby P); Bomanite Pty Ltd $v$ Slatex Corp Australia Pty Ltd (1991) 32 FCR 379, 391 (French J).

43 Chief Justice JJ Spigelman, 'Economic Rationalism and the Law' (2001) 24 University of New South Wales Law Journal 200, 203. 
much greater volume of cases could be handled by a specific number of judges if they could sit in camera, dispense with the presumption of innocence, not be constrained by obligations of procedural fairness or the need to provide a manifestly fair trial, act on the basis that no one had any rights and not have to publish reasons for their decisions. Even greater 'efficiency' would be quickly apparent if judges had made up their minds before the cases began.

Our system of justice is not the most efficient mode of dispute resolution. Nor is democracy the most efficient mode of government. We have deliberately chosen inefficient ways of decision-making in the law in order to protect rights and freedoms. ${ }^{44}$

Similarly, in the UK context, Conrad Dehn has argued that complaints about cost and delay will be made about 'any legal system which goes beyond palm tree justice and tries to ascertain the truth of the facts in dispute and the correct application of the relevant law.' ${ }^{45}$ Millett LJ in the UK Court of Appeal has observed that '[i]t is easy to dispense injustice quickly and cheaply, but it is better to do justice even if it takes a little longer and costs a little more.' 46 On this view, no apology should be made for the expensive, time-consuming, labour-intensive procedures of our system; they exist in order to achieve justice - at least for the parties.

There are several responses to these arguments. First, as pointed out above ${ }^{47}$ cost and time can be seen as dimensions of justice: arguably, justice is not done if court proceedings are so costly or prolonged as to deprive the remedy of practical utility. Secondly, the assumption that more elaborate procedures increase the chances of reaching the 'right' result can be challenged. A costly, time-consuming procedure may contribute nothing to the resolution of the case; or there may be a more efficient way of gaining the same benefit. Parties to litigation may take procedural steps for tactical reasons (such as a desire to 'inflict costs' ${ }^{48}$ on opponents), rather than by a belief that the step will help to resolve the dispute on its merits. Finally, doing justice between the parties without regard to cost and time can, as explained above, ${ }^{49}$ affect the access to justice afforded to other litigants. For all of these reasons, inefficiency should not be accepted as the inevitable consequence of doing justice; in some circumstances, inefficiency can cause injustice.

\footnotetext{
$44 \quad$ Ibid 204 (emphasis added).

45 Conrad Dehn, 'The Woolf Report: Against the Public Interest' in AAS Zuckerman and Ross Cranston (eds), Reform of Civil Procedure: Essays on 'Access to Justice' (Clarendon Press, 1995) 149, 163.

46 Gale v Superdrug Stores plc [1996] 3 All ER 468, 477-8, [1996] 1 WLR 1089, 1098 (Millett LJ).

47 At 13-14.

$48 \quad$ Gravelle, above n 37, 296.

49 At 14-15.
} 


\section{CONCLUSION}

In this chapter I have developed the ideas of justice and efficiency from the point of view of the parties and the public. Throughout the thesis, the distinction between the public and party perspectives will facilitate a precise exploration of the relationship between efficiency and justice in civil procedure. As we have already seen, this relationship is not straightforward.

One view is that inefficiency is the price we must pay for doing justice between the parties. If this were so, this thesis would address the issue of efficiency versus justice; the question would be when - if ever - courts could legitimately compromise justice for the sake of efficiency. This remains part of the question. But the reality is more complicated. Efficiency is not always opposed to justice. A court determination which comes at too great a cost may not, substantively, do justice between the parties. Doing justice between the parties may work an injustice on the public if access to justice is reduced. The aims of efficiency and justice in civil procedure will sometimes come into conflict, but at other times they will be inseparable.

This chapter has set up many of the themes of this thesis. So far, the analysis has been conducted at a fairly abstract level. In the next two chapters I introduce the practical setting in which the relationship between justice and efficiency will play out in this thesis: mega-litigation. Chapter 3 defines 'mega-litigation' for the purposes of this thesis, while Chapter 4 explains the challenges that mega-litigation presents for the justice system. These challenges raise questions about the relationship between public- and party-centred concepts of justice and efficiency. 


\section{CHAPTER 3: MEgA-Litigation Defined}

\section{INTRODUCTION}

Like the proverbial elephant, a 'long (or heavy) and complex' case is easier to recognise than to define. ${ }^{1}$

This thesis asks how judges reconcile the aims of justice and efficiency in megalitigation. Chapter 2 explained the meaning of 'justice' and 'efficiency' for the purposes of the thesis, developing both public- and party-based perspectives on each of these concepts. This chapter addresses a further definitional question: what is mega-litigation?

Various labels have been applied to the same phenomenon: 'mega-litigation', 'supercase'," 'heavy and complex' case, ${ }^{4}$ 'long and complex' case. ${ }^{5}$ It would be difficult, and probably not useful, to adopt a rigid definition which would conclusively rule actions either in or out of the class of 'mega-litigation'. Instead, for the purposes of this thesis I develop a definition which draws on various criteria, none of which are determinative. Throughout the chapter, I draw on data collected in the qualitative interviews conducted for this project, ${ }^{6}$ as well as on academic literature and case law.

Judiciary of England and Wales, Report and Recommendation of the Commercial Court Long Trials Working Party (December 2007), 15 [26]. The story of the blind men and the elephant appears in the lore of various cultures and religions. A group of blind men touch different parts of an elephant - its tusk, its leg, its side - and describe the elephant based on their impressions. According to the $19^{\text {th }}$ century American poet John Godfrey Saxe (in 'The Blind Men and the Elephant'), each man was 'partly in the right', but, none having seen the whole elephant, 'all were in the wrong'.

2 Chief Justice Murray Gleeson, 'Managing Justice in the Australian Context' (Paper presented to Australian Law Reform Commission Conference, Sydney, 19 May 2000); Acting Justice of Appeal Ronald Sackville, 'Mega-Lit: Tangible Consequences Flow From Complex Case Management' (2010) Law Society Journal 47; Martin Meredith, 'Mega-Litigation Tales From Bell, C7 and BCCI - Lessons Still to be Learnt (Part 1)' (2013) (March) Law Society Bulletin 10; Martin Meredith, 'Mega-Litigation Tales From Bell, C7 and BCCI - Lessons Still to be Learnt (Part 2)' (2013) (April) Law Society Bulletin 26; Richard L Marcus, 'Reassessing the Magnetic Pull of Megacases on Procedure' (2001) 51 DePaul Law Review 457; Justice Peter Vickery, 'Managing the Paper: Taming the Leviathan' (2012) 22 Journal of Judicial Administration 51.

3 Sackville, 'Mega-Lit', above n 2, 47; Judiciary of England and Wales, above n 1, 15 [26]; Sir Anthony Clarke MR, 'The Supercase - Problems and Solutions: Reflections on BCCI and Equitable Life' (KPMG Forensic's Annual Law Lecture 2007, London, 29 March 2007).

4 Sackville, 'Mega-Lit', above n 2, 47; Judiciary of England and Wales, above n 1, 15 [26].

$5 \quad$ Acting Justice Ronald Sackville, 'Mega-Litigation: Towards a New Approach' (2008) 8 The Judicial Review 89; Judiciary of England and Wales, above n 1, 15 [26].

6 The methodology of these interviews is explained in the Appendix. 
I begin, in section II of this chapter, by surveying some descriptions of megalitigation appearing in the literature. From these descriptions I identify five factors which can be used to ascertain whether a matter merits the label 'mega-litigation': hearing time, number of parties, number of documents, amount at stake, and legal and factual complexity. The balance of section II is devoted to examining each of these factors in turn. Mega-litigation is likely to be characterised not by any single one of these factors but by a combination of factors. Factual complexity and high stakes emerge as the crucial factors. The number of parties, length of trial and complexity of the legal issues are relevant, but not determinative, in considering whether a matter warrants the label 'mega-litigation'. The number of documents involved is, I argue, symptomatic rather than constitutive of mega-litigation. Section III considers whether there is any qualitative difference between mega-litigation and other litigation: is mega-litigation simply a bigger version of ordinary litigation? In the course of this discussion I identify an additional characteristic of mega-litigation: the parties are usually exceptionally well-resourced. I conclude the chapter by drawing together the various factors into a working definition of mega-litigation for use throughout the thesis.

\section{TOWARDS A DEFINITION OF MEGA-LitigATION}

The meaning one gives to 'mega-litigation' depends, as one interview participant pointed out,7 on the purpose the definition must serve. Michael Legg, for instance, argues that the significance of a definition is that it will enable cases to be identified, and thus treated appropriately, from an early stage. ${ }^{8}$ He therefore looks to the causes of complex litigation in order to define it. ${ }^{9}$ My objective is different. I wish to examine the way in which Australian courts have dealt with mega-litigation. For the purposes of this thesis, I require a definition of mega-litigation which is concrete enough to determine which cases fall within the scope of the project. Unlike Legg, I look to characteristics of mega-litigation which may not emerge until the case is well underway, or indeed until it has concluded.

The Long Trials Working Party in the English Commercial Court, set up in direct response to two high-profile mega-litigation matters, ${ }^{10}$ identified the following

Interview with Participant G.

Michael Legg, Case Management and Complex Civil Litigation (Federation Press, 2011), 20.

Ibid. For other approaches to defining mega-litigation, supercases or complex litigation, see

Ross Cranston, 'Complex Litigation: The Commercial Court' (2007) 26 Civil Justice Quarterly 190, 191-3.

10

Judiciary of England and Wales, above n 1, 13-14 [21]. The two matters were the BCCI and Equitable Life cases, both of which were discontinued before trial. The history of both cases is 
factors as indicators of 'long and complex', 'heavy and complex' or 'Supercase' litigation: ' $[t]$ he amount at stake in the litigation, the number of parties involved, the potential length of the trial, the number of issues raised and the complexity of the legal or technical issues'. ${ }^{11}$ The Working Party concluded that it 'could not be

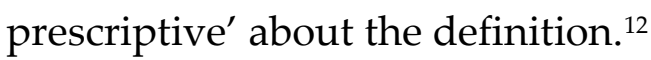

In Australia, the leading statement on the meaning of the term 'mega-litigation' is that of Sackville J in the C7 case. ${ }^{13}$ His Honour described mega-litigation as

civil litigation, usually involving multiple and separately represented parties, that consumes many months of court time and generates vast quantities of documentation in paper or electronic form. An invariable characteristic of megalitigation is that it imposes a very large burden, not only on the parties, but on the court system and, through that system, the community. ${ }^{14}$

In the qualitative interviews conducted for the purposes of this thesis, I used Sackville J's statement as a starting point for discussing the concept of 'megalitigation'. Participants generally agreed that this was a fair description of a recognisable class of litigation. One participant pointed out that Sackville J's description was not intended as a prescriptive definition, ${ }^{15}$ and another noted that it was quite vague and flexible. ${ }^{16}$ One participant thought that $C 7$ no longer 'epitomises' mega-litigation. This participant said that modern mega-litigation could involve not only multiple parties and multiple issues, but also multiple proceedings being heard together. ${ }^{17}$ This point illustrates one difficulty of arriving at a fixed definition of 'mega-litigation'; as litigation evolves, so too may the factors that characterise 'mega-litigation'.

In an effort to develop a workable definition for the purposes of this thesis, I now turn to an examination of the factors that may be used to identify a matter as 'megalitigation'. Sackville J's description in C7 is a useful starting point, as it is widely accepted as accurate (if imprecise). Sackville J identifies three indicators of megalitigation: number of parties, court time consumed and amount of documentation

described Sir Anthony Clarke MR, above n 3. For a detailed account of the BCCI litigation, see Adrian Zuckerman, 'A Colossal Wreck - The BCCI-Three Rivers Litigation' (2006) 25 Civil Justice Quarterly 287.

11 Judiciary of England and Wales, above n 1, 15 [26].

12 Ibid.

$13 \quad$ Seven Network Ltd v News Ltd [2007] FCA 1062.

14 Ibid [1].

15 Interview with the Honourable Michael Black AC QC (Melbourne, 22 November 2012).

16 Interview with Justice David Bleby (Adelaide, 16 February 2012).

17 Interview with Participant E. 
produced. I will also explore two further factors, identified by both the Long Trials Working Party and Legg as indicators of mega-litigation: 'high stakes' and complexity (legal and factual). ${ }^{18}$

\section{A Hearing Time}

Hearing time is one indicator of mega-litigation. Some notorious mega-litigation cases involved extraordinarily long trials: 404 days in Bell, 232 days in ASIC $v$ Rich, and 471 days in Duke Group. ${ }^{19}$ Interview participants tended to use the number of hearing days as a measure of the magnitude of the litigation. The 200-day trial is an obvious case of mega-litigation; indeed, so is the 100-day trial. Some participants gave examples of trials in the range of 50-80 days which they would put in the megalitigation class. The problem, when trying to develop a definition of mega-litigation, is where to draw the line. It would be somewhat arbitrary to say that a 50 day case can be mega-litigation but a 40-day case cannot.

There are other reasons why the length of the trial is an imperfect measure of the magnitude of litigation. As we shall see throughout this thesis, most complex cases are subject to judicial case management - often intensive case management - prior to trial. $^{20}$ This may mean that the trial is preceded by many directions hearings, management conferences and interlocutory arguments; a large amount of time may have been spent in court before the trial begins. Justice David Bleby of the Supreme Court of South Australia noted that mega-litigation

not only occupies a large amount of trial time but occupies a lot of management time too, sometimes for several years. And not ... week to week or month to month management but quite often vigorously contested interlocutory applications. ${ }^{21}$

Effective pre-trial case management can result in a much more efficient trial. Trial time thus becomes an inadequate measure of the burden a case places upon the court. Chief Justice Wayne Martin of the Supreme Court of Western Australia explained:

one of the consequences of the case management system ... is that hearing time is an increasingly inadequate assessment of the complexity of the case, because

\footnotetext{
18 Legg, above n 8, 18-19; Judiciary of England and Wales, above n 1, 15 [26].

19 Duke Group Ltd (in liq) v Pilmer (1998) 144 FLR 1.

$20 \quad$ See especially 132-9 and 158-61.

21 Interview with Justice David Bleby (Adelaide, 16 February 2012). For example, there were 67 reported interlocutory judgments in the ASIC $v$ Rich proceedings: Australian Securities and Investments Commission v Rich (2009) 236 FLR 1, 22 [28].
} 
we've been able to expedite hearing times. You can have massive amounts of documentation introduced into evidence in the blinking of an eye, it doesn't take very long, and again because a lot of submissions are done in writing, a lot of the case is prepared in advance of the hearing. A case can be a massive case and nevertheless not engage a huge amount of hearing time. So I think hearing time is probably a less reliable guide..$^{22}$

One participant identified a distinct category of case which he would describe as mega-litigation although it does not consume months of court time. This participant had heard several cases with the following characteristics:

A complex commercial dispute with significant consequences that is brought to court with a high degree of haste so as to achieve a very early outcome. And it puts strain on the system in that way, not necessarily by its length, but by the intensity of the litigation and the necessity to determine it as early as possible. ... We have cases ... which have mountains of paper to start with but come to court very swiftly and require urgent resolution involving hundreds of millions of dollars, for significant commercial issues, and whilst they may not take weeks or months I still think those fall within, properly speaking, a category of megalitigation where there's huge resources committed to them by the parties and the court has to make do with whatever resources we have to make sure that the commercial community is satisfied with the way in which these disputes are dealt with. That to me is mega-litigation as well. ${ }^{23}$

Hearing time at trial can also be deceiving when a case does not proceed to judgment. Some well-known examples of mega-litigation have either settled, ${ }^{24}$ been discontinued, ${ }^{25}$ or been dismissed prior to the end of the trial. ${ }^{26}$

In sum, the length of the trial is an important, but not conclusive, factor in developing a definition of 'mega-litigation'. A very long trial will be a strong indication that a case falls within the 'mega-litigation' category. But a long trial is not a necessary factor; it is possible to have a case of mega-litigation which does not involve a long trial.

\footnotetext{
22 Interview with Chief Justice Wayne Martin (Perth, 6 March 2013). The management of documentary evidence and the use of witness statements in mega-litigation are discussed in Chapter 9 at 175-9.

23 Interview with Participant A.

24 For example, the Centro litigation in Victoria in 2012 (see Kirby v Centro Properties Ltd (No 6) [2012] FCA 650).

25 For example, the BCCI/Three Rivers case in the UK (see Zuckerman, above n 10).

26 See, eg, Idoport Pty Ltd v National Australia Bank Ltd [2002] NSWCA 271.
} 


\section{B Multiple Parties}

Sackville J described mega-litigation as 'usually involving multiple and separately represented parties' ${ }^{27} \mathrm{C} 7$ itself involved two applicants and 20 respondents, ${ }^{28}$ who divided into ten separately represented groups. There were 30 plaintiffs and 21 defendants in the Bell Group proceedings, but all the plaintiffs shared representation at trial, as did all the defendants. For some interview participants, the number of parties was a major factor contributing to the size of the litigation, and a factor distinguishing mega-litigation from ordinary litigation. ${ }^{29}$ One participant said:

I assume that in theory you could have mega-litigation between two parties because it could involve that many issues, but in practice I think ... the greater the number of parties, almost inevitably means the greater the number and potential complexity of the issues and the length of the court time. ${ }^{30}$

But other participants had experienced mega-litigation involving only two or three parties. $^{31}$ ASIC $v$ Rich involved only three parties (the corporate regulator against two individuals), as did the long-running Alstom Power litigation in South Australia. Once again, then, the number of parties emerged as an important but not decisive factor in defining mega-litigation: it is possible to have mega-litigation without a large number of separately represented parties.

\section{Number of Documents}

Sackville J identified the generation of 'vast quantities of documentation' as a distinguishing feature of mega-litigation. ${ }^{32}$ The number of documents involved in these cases is staggering. The pleadings in C7 ran to 1028 pages. ${ }^{33} 86,340$ documents were tendered in the Bell Group trial. ${ }^{34}$ The closing submissions in ASIC $v$ Rich totalled 4,348 pages. $^{35}$ Small wonder, then, that the volume of documents involved should be cited as a key characteristic of mega-litigation.

Seven Network Ltd v News Ltd [2007] FCA 1062, [1].

The applicants initially sued 19 parties. The case settled against two of them (AFL and Channel $10)$, and three additional respondents were joined after proceedings had commenced. Interview with the Honourable Michael Black AC QC (Melbourne, 22 November 2012); Interview with the Honourable Ray Finkelstein QC (Melbourne, 21 November 2012). Interview with Participant B. Interview with Justice David Bleby (Adelaide, 16 February 2012); Interview with Justice Peter McClellan (Melbourne, 5 June 2012); Interview with Participant H. Seven Network Ltd v News Ltd [2007] FCA 1062, [1]. See also Justice Peter Vickery, 'Managing the Paper: Taming the Leviathan' (2012) 22 Journal of Judicial Administration 51. Seven Network Ltd v News Ltd [2007] FCA 1062, [16]. Bell Group Ltd (in liq) v Westpac Banking Corporation (No 9) (2008) 39 WAR 1; [2008] WASC 239, [956]. Australian Securities and Investments Commission v Rich (2009) 236 FLR 1, 21. 
One interview participant, the Honourable Ray Finkelstein QC, thought it unwise to place too much emphasis on the volume of paper in classifying a case as megalitigation. It was possible, he thought, to have very long and complex litigation that did not involve large volumes of documentation. Furthermore, he did not think that the existence of a large amount of paper necessarily contributed to the complexity of litigation. Often, in his experience, when massive numbers of documents were filed,

No court pays attention to anything more than a handful of them. It will cost a lot to produce the documents that are provided to the court but in the end ... the documents are put together for the judge usually do not aid the process of reaching a just result. ${ }^{36}$

The presence of large numbers of documents may not, in itself, be a defining feature of mega-litigation. But it is likely to reflect other factors: complex or wide-ranging factual issues; well-resourced parties prepared to pour large sums of money into the litigation; lawyers taking an exceptionally thorough approach. The amount of documentation involved in a case is better seen as a symptom, rather than a constitutive feature, of mega-litigation.

\section{High Stakes}

The amount at stake in litigation is an obvious indicator of mega-litigation. ${ }^{37}$ It makes good economic sense for a party to invest large amounts of time and money in litigation if they stand to gain or lose an even greater amount. As Wayne Martin explained:

The problem in the mega-litigation case is that there is usually so much money involved that cost is no object to the parties. ... And the normal rational constraints that apply to normal litigants [mean that if] the case is worth let's say $\$ 2$ million, rational litigants will not spend more than $\$ 500,000$ on their legal costs pursuing a $\$ 2$ million case and issue. If the amount involved is $\$ 2$ billion, then rational litigants will spend up to $\$ 500$ million each. ${ }^{38}$

In Bell Group, for instance, the plaintiffs' party and party costs after the trial were around $\$ 82$ million; 39 a huge sum of money but, as it turned out, a good investment: they were awarded over $\$ 1.6$ billion plus interest. Mega-litigation cases are often disputes about entitlement to sums of $\$ 100$ million and upwards. In other cases,

\footnotetext{
Interview with the Honourable Ray Finkelstein QC (Melbourne, 21 November 2012).

See Legg, above n 8, 19.

Interview with Chief Justice Wayne Martin (Perth, 6 March 2013).

See Westpac Banking Corporation v Bell Group Ltd (in liq) [2009] WASCA 166, [3]. The legal costs for the entire dispute have been reported as \$500 million: Richard Gluyas, 'Banks in Bell Group Settlement', The Australian, 18 September 2013.
} 
there may be significant non-monetary consequences. ASIC $v$ Rich, one of the archetypal instances of mega-litigation, was not a dispute about entitlement to money; it was a civil penalty proceeding by ASIC against directors of the defunct telecommunications company, One.Tel Ltd. The potential consequences for the defendants were significant: they faced the possibility of tremendous damage to their professional reputations and earning potential, as well as having to pay substantial compensation. ${ }^{40}$

High stakes, then, appear to be a necessary feature of mega-litigation. But high stakes do not always lead to mega-litigation. It is possible to have a straightforward claim for a large sum of money that resolves quickly. Something more is needed to create mega-litigation. That 'something more' may be the final factor in this list: legal or factual complexity.

\section{E Complexity}

A characteristic which seems common to all cases of mega-litigation is the complexity of the factual issues, the legal issues, or both. Many interview participants identified the number and complexity of legal and factual issues as a feature of mega-litigation. ${ }^{41}$

Mega-litigation can sometimes involve the resolution of unsettled questions of law. C7, for example, involved difficult questions about the definition of markets for the purposes of the Trade Practices Act 1974 (Cth). One interview participant identified the 'importance of the issues' as a major factor:42 if a case raises a novel legal issue of ongoing significance to the parties, the case is likely to be hard-fought, with extensive legal argument on both sides. But legal complexity does not, on its own, create mega-litigation. Appellate courts regularly determine complex legal questions following a one- or two-day hearing, and with strict limits on the

40 Orders made by consent against two other directors of One.Tel provide an indication of what was at stake. Mr Keeling was ordered to pay $\$ 92$ million compensation and was disqualified from being a director for 10 years: Australian Securities and Investments Commission v Rich (2003) 21 ACLC 672. Mr Greaves was ordered to pay $\$ 20$ million compensation, and disqualified for four years: Australian Securities and Investments Commission v Rich (2004) 22 ACLC 1232.

41 Interview with the Honourable Michael Black AC QC (Melbourne, 22 November 2012); Interview with the Honourable Ray Finkelstein QC (Melbourne, 21 November 2012); Interview with Justice Peter McClellan (Melbourne, 5 June 2012); Interview with Justice David Bleby (Adelaide, 16 February 2012); Interview with Justice David Harper (Melbourne, 19 November 2012); Interview with the Honourable Neville Owen (King's Park, WA, 5 March 2013); Interviews with Participants B and $\mathrm{H}$. Interview with Participant B. 
documents that may be filed. ${ }^{43}$ Factual, rather than legal, complexity is likely to mark a matter out as mega-litigation.

There is interplay between factual complexity and some of the factors already discussed. The involvement of multiple parties creates complexity. In Bell Group, for instance, there were effectively ' 21 separate trials' ${ }^{44}$ against 21 separate defendants. There is also a clear connection between the complexity of the factual issues and the volume of documents. Justice David Harper of the Supreme Court of Victoria explained that cases reach the proportions of mega-litigation because of

the volume of evidence, which very often is connected with the complexity of the issues. If there are a large number of issues which can only be dealt with or determined on the basis of a large quantity of evidence then necessarily that evidence has to be produced, or called. Sometimes the legal issue can be quite straightforward but nevertheless because there is a very heavy contest about what happened, the evidence on each side is voluminous... ${ }^{45}$

If a case centres on the failure of a significant commercial venture, it can mean both that the stakes are high and that the task of unravelling the web of commercial relationships underlying the dispute is extremely complex. In ASIC $v$ Rich, ASIC's case required them to establish the financial circumstances of One.Tel and its subsidiaries over a period of four months. The One.Tel group was 'a large multinational corporate group with various businesses, some in start-up mode and some more established' ${ }^{46}$ One.Tel had operated in eight countries and had over 3000 employees. ${ }^{47}$ Inquiring into the financial circumstances of a corporate group of this scale made for an extremely wide-ranging evidentiary case. ${ }^{48}$

From this examination of the factors that may identify mega-litigation, we start to get a sense of the type of case with which this thesis is concerned: complex, longrunning, high stakes litigation. Of these, complexity - especially factual complexity - appears to be the single feature that sets mega-litigation apart. Yet the other factors considered are neither unique, nor necessary, features of mega-litigation. In

43 Parties to an appeal in the High Court, for example, are generally limited to 20 pages of submissions (plus a five-page reply for the appellant): High Court Rules 2004 (Cth) Part 44.

$44 \quad$ Bell Group Ltd (in liq) v Westpac Banking Corporation (No 9) (2008) 39 WAR 1; [2008] WASC 239, [5], [954].

45 Interview with Justice David Harper (Melbourne, 19 November 2012).

$46 \quad$ Australian Securities and Investments Commission v Rich (2009) 236 FLR 1, 32 (Austin J).

$47 \quad$ Ibid 142.

48 Austin J described the nature of ASIC's case as 'by far the single biggest contributing factor to the length of the hearing': Ibid 21. 
the next section, therefore, I consider whether anything makes mega-litigation truly different from other types of litigation.

\section{QUALITATIVELY DIFFERENT FROM ORDINARY LITIGATION?}

In an effort to isolate the most distinctive features of mega-litigation, I asked participants whether they perceived a qualitative difference between mega-litigation and other litigation, or if the difference was only in size. The majority of participants thought there was a qualitative difference.

Interview participants consistently identified three factors that made mega-litigation different from other litigation. The first was the number of issues involved in megalitigation $^{49}-$ a consequence of the factual or legal complexity of the case. Participants spoke of the intellectual challenge of absorbing and synthesising material relating to a large number of issues:

There are just so many issues that are thrown up - in documents, in statutes and the like - that they just become much more difficult to just get your head around and to write about at the end of it..$^{50}$

[A mega-litigation matter] was reaching the limits of my ability to hold everything in. ${ }^{51}$

There must be a sort of point at which, as one person, you're confronted by so many issues that it just creates ... certainly an exponentially different feeling of an enormous amount of work to get through them. ${ }^{52}$

Implicit in these quotes is the second factor that some participants spoke of as qualitatively different in mega-litigation: mega-litigation is 'extremely burdensome on a judge'.53 The burden begins at the pre-trial stage, with huge amounts of material for the judge to absorb and frequent case management hearings. ${ }^{54} \mathrm{~A}$ megalitigation trial may monopolise the judge's time for months or years. After the hearing, the judge faces the task of writing a judgment. Justice Robert McDougall of the NSW Supreme Court said mega-litigation was

49 Interviews with Participants B, D, E, F and G.

50 Interview with Participant F.

51 Interview with Justice Robert McDougall (Sydney, 6 June 2012).

52 Interview with Participant B.

53 Interview with Participant A. Others expressed a similar view: Interview with the Honourable Neville Owen (King's Park, WA, 5 March 2013); Interview with Justice Robert McDougall (Sydney, 6 June 2012); Interview with Participant G.

$54 \quad$ Interview with Justice David Bleby (Adelaide, 16 February 2012); Interviews with Participants $\mathrm{D}$ and $\mathrm{E}$. See also the discussion of the workload implications of intensive case management in Chapter 8 at 138 . 
qualitatively different in the demands it makes on the trial judge. Because you can sit and hear a [normal] case and you can give an ex tempore judgment at the end if it's a fact driven case ... or you can reserve and deliver a judgment a month later if you've got to think about it, that's fine. But with mega-litigation the issues are just so complex, the evidence can be - and usually is - so diverse, that it is really, really hard for one person to keep track of it all..$^{5}$

Other participants agreed that writing a judgment in mega-litigation was a tremendous challenge due to the volume of material to be assimilated, and the number of hotly contested issues. ${ }^{56}$

The third factor that emerged as a distinguishing feature of mega-litigation was the attitude of the parties and their lawyers to the dispute. Former Federal Court judge, the Honourable Malcolm Lee QC, reported that

[Mega-litigation proceedings] do seem to take on a life of their own. One of the problems with it is the feeling that can be underlying it on all sides that it is big, and that it can't be mastered. [The lawyers] are only on top of certain sections of it. And [there are] too many unknowns in it. That all then transfers from the way counsel are presenting it to the judge's position. ... [I]t's very difficult ... for a judge to impose discipline when it's beyond the control of the representing parties. ${ }^{57}$

While Lee tended to see lawyers as passive victims of an overwhelmingly complex dispute, others cast lawyers and parties in a more active role in the creation of megalitigation. In his judgment in the $C 7$ case, Sackville J identified as ' $[\mathrm{t}]$ he fundamental difficulty facing a court hearing mega-litigation' the fact that 'the parties may decide, for whatever reason, to engage in a full-blown forensic battle in which almost every barely arguable issue is examined in depth.' 58 The Honourable Michael Black AC QC took the military analogy a step further when discussing the difference between mega-litigation and ordinary litigation:

[T] he difference may be that in mega-litigation the resources at the disposal of the parties are larger, the sense of ... financial and other containment that you get in

55 Interview with Justice Robert McDougall (Sydney, 6 June 2012).

56 Interview with Justice David Harper (Melbourne, 19 November 2012); Interview with Participant F. See also Justice Clifford Einstein, 'Reflections on the Commercial Litigation Landscape - Lessons From the Past - Moving Forward' (2005) 26 Australian Bar Review 145, 1537.

57 Interview with the Honourable Malcolm Lee QC (Fremantle, 6 March 2013). 
ordinary litigation is less strong, maybe even absent. So that it's ... more like a full-scale war than a battle. ${ }^{59}$

Another participant described a similar lack of containment on the part of wellresourced parties:

[Y]ou would usually find that the parties who are in a position to conduct [megalitigation] have got the resources to conduct it and so huge resources are often committed to these cases. ... Because there's huge resources you might find that issues are pursued that might otherwise not be pursued. ${ }^{60}$

A third participant, Robert McDougall, made similar observations about the attitude of parties to mega-litigation, but linked them to the personality, as well as the resources, of the parties:

I do think that corporate or, in some cases, individual ego is far more influential in mega-litigation than it is in ordinary litigation. I think people with a lot of money are prepared to spend a lot of it to try and vindicate their position, whereas more rational human beings say 'well, why would I spend \$1 million for a 50\% chance of recovering $\$ 1.5$ million?' The answer is obvious: 'I'll settle the

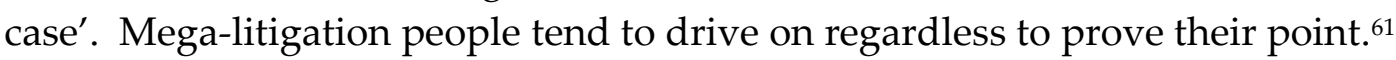

This discussion of the effect of the attitudes of parties and their lawyers raises the question of whether a further factor ought to be added to the criteria for identifying features of mega-litigation: the resources of the parties. Wayne Martin said it was possible to identify a matter which would become mega-litigation at a very early stage: ${ }^{22}$ 'You look at the parties. If they're very well-heeled litigants and the amount involved is substantial you know it's going to blow out.' 63 While the attitude of the parties and their lawyers may be too subjective a matter to form part of a workable definition of mega-litigation, the resources of the parties are a quantifiable matter that can be taken into account in forming a definition of mega-litigation.

While most participants perceived a qualitative difference between mega-litigation and ordinary litigation, two participants said mega-litigation was no different from ordinary litigation:

\footnotetext{
59 Interview with the Honourable Michael Black AC QC (Melbourne, 22 November 2012).

60 Interview with Participant A.

61 Interview with Justice Robert McDougall (Sydney, 6 June 2012).

62 Another participant, Federal Court judge Participant E, agreed that the identity of the parties was a significant indicator that a matter was going to become mega-litigation. 
There is nothing different about [mega-litigation] cases. They are normal cases with normal problems, they are just longer and have more issues. This means it is harder for everyone (the parties, the lawyers and the judge) because ... they have to prepare a lot for a long case ... . And the more issues there are the more preparation is involved and the harder it becomes. ${ }^{64}$

[I]t's just a question of bulk, so qualitatively it's much the same, but you have to tailor your procedures and you have to invent new procedures. ... [Y]ou do invent new ways of approaching things. But qualitatively no, it's quantitative. ${ }^{65}$

A third participant expressed a similar view that the fundamental judicial task - the 'determination of disputed issues' was 'exactly the same' in mega-litigation; but the court's task in managing mega-litigation was 'administratively and practically different', calling for 'a different approach ... in terms of management by the court' ${ }^{66}$ In one sense these three participants were not so different from those who said there was a qualitative difference in mega-litigation. Their point was that, at heart, megalitigation requires judges to determine disputed issues just as any other litigation does. They seemed to agree, though, that mega-litigation presented different challenges and required judges to act in different ways from ordinary litigation.

\section{CONCLUSION: MEGA-LITIGATION DEFINED}

Mega-litigation remains 'easier to recognise than to define. ${ }^{\prime 67}$ The discussion, in this chapter, of the importance of a range of factors demonstrates the difficulty of attempting to use bright-line definitions in this area. For the purposes of this thesis, however, I will adopt the following parameters. By 'mega-litigation' I mean civil litigation between well-resourced parties involving many complex factual (and, sometimes, legal) issues, with the stakes usually exceeding $\$ 100$ million (or very significant non-monetary consequences), the trial often (but not necessarily) taking upwards of 50 days, and often involving multiple parties.

I have suggested that factual complexity is the most significant factor. However, none of the factors is unique to mega-litigation and none, by itself, is determinative. It is the combination of these factors that marks out a matter as mega-litigation. There is much interplay between the factors. Well-resourced parties may be willing to commit large amounts of resources to the litigation, particularly if the stakes are high. Armed with those resources, the parties and their lawyers may be willing to pursue marginal issues, thus creating legal and factual complexity. The proliferation

\footnotetext{
64 Interview with the Honourable Ray Finkelstein QC (Melbourne, 21 November 2012).

65 Interview with the Honourable Neville Owen (King's Park, WA, 5 March 2013).

66 Interview with Participant E.

67 Judiciary of England and Wales, above n 1, 15 [26].
} 
of issues, backed by virtually limitless resources, in turn leads to the production of massive piles of documents. Add to this a party not inclined to concede any ground in a fight, with a purse large enough to ensure they never have to do so, and you have mega-litigation.

Is there an identifiable point at which a matter passes from ordinary to megalitigation? One participant described a 'tipping point ... when a case changes its demands' on the judge. ${ }^{68}$ This tipping point, however, came when a trial reached about ten days - hardly mega-litigation. A related question that sometimes arises is whether there is any difference between 'mega-litigation' or the 'supercase', and 'complex litigation'. Ross Cranston takes the position that the 'super or mega case', exemplified by the BCCI and Equitable Life cases in the UK, and by Bell Group, ASIC v Rich and $C 7$ in Australia, should be regarded as 'exceptional', and therefore not productive of any generalisable lessons for litigation that is merely 'complex'.69 I prefer the view, put forward by one interview participant, that it is possible to place litigation along a continuum, with very simple cases at one end and mega-litigation at the other..$^{70}$ It may not be possible to identify a 'point at which we move beyond orthodox litigation into an entirely new category you call mega-litigation'. ${ }^{71}$ But, at the mega-litigation end of the continuum, 'the management problems are very different from those that arise in the more usual run of the mill cases. ${ }^{\prime 2}$ The sheer size of a case like Bell Group may be exceptional, but there is no reason why this case should be treated differently from cases which sit close to it on the continuum.

As explained in Chapter 1, this thesis considers civil rather than criminal litigation. ${ }^{73}$ Further, I have chosen to focus on commercial litigation. This is partly in order to narrow the scope of the enquiry, but also because most cases of mega-litigation are commercial disputes. Many native title claims would readily satisfy my definition of mega-litigation; so would some civil actions against public authorities. ${ }^{74}$ There are factors at play in these sorts of cases that are absent from purely commercial litigation. There may be significant inequalities in the resources of the parties on either side; and issues of public importance may be at stake. Therefore the question of the proportion of court's resources should be committed to these cases is

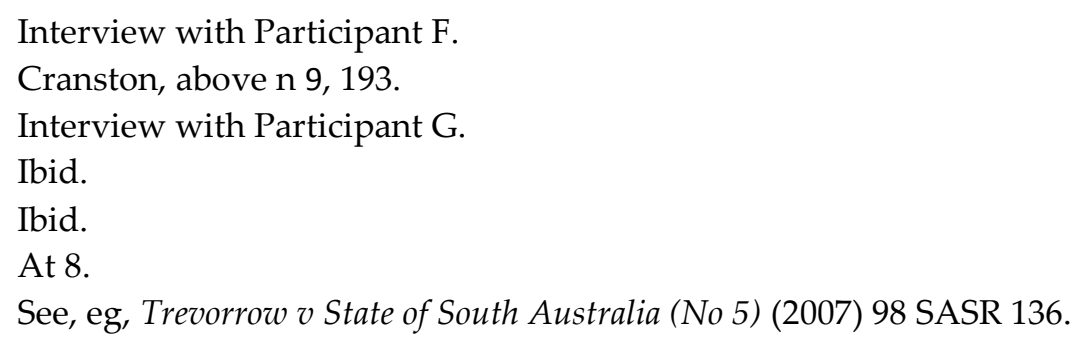


influenced by different considerations than when the dispute is about the division of a large sum of money between well-resourced litigants. I have not entirely excluded these non-commercial civil cases from consideration, and have drawn on them throughout to illustrate certain points. Two interview participants were chosen for their experience in non-commercial mega-litigation, ${ }^{75}$ and were able to provide insights into the challenges and dynamics of mega-litigation generally. However, my analysis and conclusions in this thesis are targeted towards commercial litigation between well-resourced parties.

The definition developed in this chapter is necessarily somewhat imprecise. This imprecision will not affect the analysis; little is to be gained by discussing whether a particular case falls on one side of the line or the other. My definition serves the purpose of identifying a class of cases that presents a particular set of challenges for the court system. Few, if any, of the acknowledged cases of mega-litigation will fall outside this definition.

Having explained what I mean by 'mega-litigation', in the next chapter I will explore the challenges that mega-litigation presents for the justice system. 


\section{ChaPter 4: Mega-Litigation: A Challenge FOR THE JUSTICE SySTEM}

\section{INTRODUCTION}

From time to time during the last five years I felt as if I were confined to an oubliette. There were occasions on which I thought the task of completing this case might be sempiternal. Fortunately, I have not yet been called upon to confront the infinite and, better still, a nepenthe beckons. Part of the nepenthe (which may even bear that name) is likely to involve a yeast-based substance. It will most certainly involve a complete avoidance of making decisions and writing judgments. ${ }^{1}$

This thesis asks how judges reconcile the objectives of justice and efficiency in megalitigation. This question is important because mega-litigation places a huge burden on the justice system, thus bringing considerations of public justice and public efficiency to the fore. The previous chapter developed a definition of mega-litigation for the purposes of this thesis. In this chapter, I will explain the challenges that mega-litigation presents to the justice system. An examination of the causes of mega-litigation suggests these challenges are likely to persist in the future.

Section II of this chapter identifies three distinct, but interrelated, burdens imposed by mega-litigation. First, as the quote introducing this chapter illustrates, each judge who presides over mega-litigation shoulders a heavy personal burden. Secondly, mega-litigation diverts court resources from other matters and therefore places a burden on the court system. To return to the concepts introduced in Chapter 2, mega-litigation has consequences for public justice, because it affects access to justice for other litigants. Thirdly, because the court resources consumed by mega-litigation are public resources, mega-litigation places a burden on the whole community: a burden I would characterise as a public efficiency concern.

Section III considers the causes of mega-litigation, focusing on whether megalitigation is likely to increase, or at least continue, in the future. The causes of megalitigation include the complexity of modern commerce; the proliferation of documents facilitated by technology; the availability of funding to run litigation both from the parties' own pockets and those of litigation funders; the trend in the substantive law towards contextual, fact-sensitive causes of action; and the adversarial culture of the legal profession. These causes are likely to persist for the foreseeable future.

Bell Group Ltd (in liq) v Westpac Banking Corporation (No 9) (2008) 39 WAR 1, 908-9 [9761]. This is the second to last paragraph in the Bell Group judgment, a judgment which took two years to write and followed a 404 day trial. 
Section IV explains the concern at the heart of this thesis: the potential for a conflict between justice and efficiency in mega-litigation. With reference to qualitative interview data and specific case examples, I consider the circumstances in which this conflict can arise. This sets the scene for the exploration, in the remainder of the thesis, of ways of resolving tensions between justice and efficiency.

This chapter will establish that mega-litigation poses serious and ongoing challenges for the administration of justice in Australia. Further, the chapter will show why discussions of the way in which courts deal with mega-litigation inevitably involve considerations of public justice and public efficiency. A mega-litigation matter does not affect only the parties and judges involved in the case. It affects every taxpayer and every user of the justice system. This is why, in mega-litigation, the task of the court goes beyond doing justice between the parties, and why tension between competing objectives of civil procedure can arise.

\section{Mega-Litigation: A Problem For the Justice System}

Sackville J's description of mega-litigation, discussed in the previous chapter, ${ }^{2}$ included the observation that mega-litigation invariably imposes a very large burden, not only on the parties, but on the court system and, through that system, the community.' ${ }^{3}$

The parties to mega-litigation incur enormous costs. Some well-publicised figures illustrate the point. Channel Seven's costs in the $C 7$ trial were estimated at $\$ 100$ million, and the respondents' costs (which Channel Seven, as the unsuccessful party, had to pay) were another $\$ 100$ million. ${ }^{4}$ Bell Group generated a reported $\$ 500$ million in lawyers' fees. ${ }^{5}$ The 2012 litigation over the liquidation of Centro was reported to cost the parties $\$ 1000$ per minute in court. ${ }^{6}$ The costs for the parties, however, are not the main motivation for this thesis. These are, as outlined earlier, ${ }^{7}$ extremely well resourced parties who have made the choice - whether driven by a rational cost-benefit analysis, or by ego - to engage in large scale litigation. Defendants do not, strictly speaking, 'choose' to participate in litigation, but their choices about which issues to contest certainly contribute to the scope and intensity of the litigation. The courts, on the other hand, do not choose the disputes that come

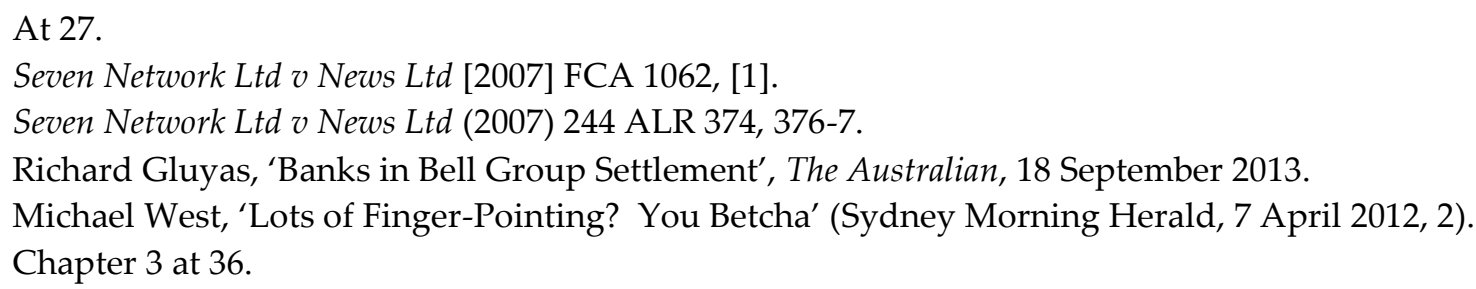


before them. My primary concern is with the burden that mega-litigation places on judges, courts and the community.

Mega-litigation places a 'huge burden ... upon a single judge'. ${ }^{8}$ Some interview participants spoke of the personal effect of hearing a very long trial. The Honourable Neville Owen, who devoted five years almost exclusively to the Bell Group litigation, offered the following account:

My spouse said I was just almost impossible to live with. ... You get this feeling of oppression, that you're locked in and you can't escape. ... You just have to resign yourself to the fact that you're there. You're there, you're trapped, there's no way out, you've just got to finish it. But ... when you can't see an end in sight, it can become psychologically disturbing. ${ }^{9}$

Another interview participant who had heard a very long trial also spoke of the personal challenges that this experience presented:

I was very conscious that I couldn't just throw up my hands and say 'this is all too hard, I'm going to go home and put my head under the blanket and go to sleep for a week', you can't do that. But it does impose enormous burdens. People tend to overlook that curiously enough judges are actually people, and they have the same sort of problems that other people have. They have health problems, they have family problems, all the usual range of afflictions that affect a human being. You've got to be very careful, I think, that you don't impose burdens on judges that are just too much for them to bear. ${ }^{10}$

A third participant said one of the biggest challenges of hearing mega-litigation was 'not to burn out'. ${ }^{11}$ Neville Owen has pointed out that the three judges who heard the iconic mega-litigation cases of the mid-2000s (Bell Group, C7 and ASIC v Rich) all retired well short of their compulsory retirement age: a substantial loss, to the justice system, of experienced judicial officers. ${ }^{12}$ It is clear that mega-litigation is extremely demanding in terms of the time and effort required of a judge, at both the trial and pre-trial phases. ${ }^{13}$

Idoport Pty Ltd v National Australia Bank Ltd [2001] NSWSC 868, [68] (Einstein J).

Interview with the Honourable Neville Owen (King's Park, WA, 5 March 2013).

Interview with Participant $\mathrm{G}$.

Interview with Participant A.

Owen J, 'Farewell to the Honourable Justice Neville Owen' (Retirement speech delivered at special sitting of the Supreme Court of Western Australia, 2 July 2010). Justice Owen retired at age 62, Justice Austin at 63 and Sackville at 64 .

13

Several interview participants spoke of this burden: Interview with Justice David Bleby

(Adelaide, 16 February 2012); Interviews with Participants A, D, E, F and G. 
Quite apart from its effect on individual judges, mega-litigation has far-reaching consequences for the justice system. The Bell Group litigation provides an extraordinary illustration of this point. The Western Australian government provided the courts with funding of $\$ 4.2$ million solely for the purpose of the Bell Group appeal. ${ }^{14}$ Three former Federal Court judges were brought out of retirement to hear the case. Any person with a passing interest in court administration will appreciate how difficult it is to secure additional funds for the justice system, even for measures that will benefit all litigants. ${ }^{15}$ Western Australian Chief Justice Wayne Martin lamented that the injection of funds for the Bell appeal was 'money that I could have spent very usefully elsewhere in this system. For example ... for a fraction of that we could have got full electronic filing. ${ }^{16}$ Ordinarily, of course, courts will not receive extra money to deal with mega-litigation. Instead, they will have to manage within the bounds of their existing resources. Any single case of mega-litigation virtually monopolises the time of the judge responsible for that case. This is so, not only during the trial, but also while writing the judgment. As Austin J, who presided over ASIC $v$ Rich, explained:

It is obviously desirable, if possible, for the judge who has heard such a long and complex case to be relieved of other work while the judgment is in preparation. Distraction from the main task has a compound effect, because it is necessary not only to take time out to hear other cases that are assigned, and to prepare judgments in them, but then to spend time working back into the main case in order to reach the state of understanding of the evidence that one possessed before the distraction occurred. ${ }^{17}$

All of this means that a single case of mega-litigation can effectively deprive a court of a judge for a period of months or even years. One former head of jurisdiction explained:

These types of cases are very challenging for courts. Because you know that you are going to lose a judge from the ordinary work of the court for a lengthy period. And that is very challenging because courts are never, in my experience,

14 Christian Porter (Attorney-General and Treasurer), 'Three Judges Appointed for Bell Group Appeal' (Media Release, 3 December 2010); Neale Prior, 'WA May Be Big Winner in Bell Group Wrangle', The West Australian (online), 18 April 2011

http://au.news.yahoo.com/thewest/business/a/-/business/9213511/wa-may-be-big-winner-inbell-group-wrangle/.

15 See, eg, Michael Lavarch, 'Fighting the Fiends From Finance' in Helen Stacy and Michael Lavarch (eds), Beyond the Adversarial System (Federation Press 1999) 10; Chief Justice John Doyle, 'The Machine of Justice - Who is Driving It?' (2007) 28 Adelaide Law Review 7, 20.

16 Interview with Chief Justice Wayne Martin (Perth, 6 March 2013).

17 Australian Securities and Investments Commission v Rich (2009) 236 FLR 1, 30. 
over-resourced and increasingly they are under-resourced. So there's just no slack in them. So if you lose a judge ... there's a big hole in your capacity to deal promptly with all the other cases. ${ }^{18}$

Similarly, another head of jurisdiction said mega-litigation was 'enormously disruptive' to the court's business. ${ }^{19}$

The burden that mega-litigation places on the court system is, of course, not merely an 'administrative headache' 20 for heads of jurisdiction and court administrators. It harms the whole community in two ways. First, mega-litigation has undesirable consequences for public efficiency. The resources expended on mega-litigation whether in a one-off, targeted payment as in the Bell Group appeal, or in the proportion of court time devoted to these cases - are public resources. Taxpayers' money expended on these cases could have been spent elsewhere within the justice system, or on other government responsibilities. Instead, it is spent on a single dispute between extremely wealthy litigants.

Secondly, mega-litigation affects public justice. During the life of a mega-litigation matter, the judge responsible for the case has very little time for any other matters. This, of course, reduces the amount of judicial time available, across the court, for other matters in the court's list. ${ }^{21}$ Justice Steven Rares describes the problem in these terms:

if these enormous cases continue to enter the court system, judges will become dedicated, sometimes for years, to hearing them while other litigants must wait for that case to be decided before the judge will become available again for other work. ${ }^{22}$

Mega-litigation, then, becomes an impediment to access to justice. Access to justice is a constant concern for Australian governments. Ronald Sackville has observed that '[a]t almost any given time in Australia, there is an inquiry under way into access to justice or consideration is being given to the latest report on the subject.' ${ }^{23}$

18 Interview with the Honourable Michael Black AC QC (Melbourne, 22 November 2012).

19 Interview with Chief Justice Wayne Martin (Perth, 6 March 2013).

20 Interview with the Honourable Michael Black AC QC (Melbourne, 22 November 2012).

${ }^{21} \quad$ See, eg, Justice Steven Rares, 'What Is a Quality Judiciary?' (2011) 20 Journal of Judicial Administration 133, 143; Australian Securities and Investments Commission v Rich [2005] NSWSC 489, [15].

$22 \quad$ Rares, above $\mathrm{n} 21,143$.

23 Acting Justice of Appeal Ronald Sackville, 'Access to Justice: Towards an Integrated Approach' (2010) 11 The Judicial Review 221, 231. Sackville refers to the following inquiries: Commission of Inquiry into Poverty, Law and Poverty in Australia, Second Main Report (R Sackville, Commissioner for Law and Poverty), Australian Government Publishing Service, October 1975; 
The effect of mega-litigation on access to justice adds a degree of urgency to the quest for efficiency in mega-litigation. What is at stake is not only the time and money of well-resourced parties, the wellbeing of judges or the expenditure of public funds - important as these matters are. Every minute of court time spent on mega-litigation is time not spent on other matters. The same could, of course, be said of any type of litigation. But mega-litigation can occupy months and years of court time. The consequences for the administration of justice as a whole cannot be ignored.

\section{CAUSES OF MEGA-LiTIGATION}

In this chapter so far, I have argued that mega-litigation is a problem for the justice system. But is it an ongoing problem? Or was the concurrence of Bell Group, C7 and ASIC $v$ Rich an aberration, unlikely to recur?

Some claim that mega-litigation is becoming increasingly common. ${ }^{24}$ It is difficult to assess the accuracy of this assertion. Certainly, mega-litigation is not new. ${ }^{25}$ Well known Australian mega-litigation cases include the 1960s American Flange litigation, ${ }^{26}$ Pacific Acceptance Corporation Ltd v Forsyth, decided in 1970 following a

Access to Justice Advisory Committee, Access to Justice: an Action Plan, AGPS, Canberra, 1994; Louis Schetzer, Joanna Mullins and Roberto Buonamano, Access to Justice and Legal Needs: A Project to Identify Legal Needs, Pathways and Barriers For Disadvantaged People in NSW (Law and Justice Foundation of NSW, Sydney, 2002); Access to Justice Taskforce, Attorney-General's Department (Cth), A Strategic Framework for Access to Justice in the Federal Civil Justice System, September 2009. See also Senate Legal and Constitutional Affairs References Committee, Impact of Federal Court Fee Increases Since 2010 on Access to Justice in Australia, June 2013. At the time of writing, the Productivity Commission was undertaking an inquiry into access to justice: see Productivity Commission, Access to Justice Arrangements: Draft Report, April 2014.

24 Seven Network Ltd v News Ltd [2007] FCA 1062, [3]; Acting Justice Ronald Sackville, 'MegaLitigation: Towards a New Approach' (2008) 8 The Judicial Review 89; Foreword to Michael Legg, Case Management and Complex Civil Litigation (Federation Press, 2011), vi; Justice Clifford Einstein, 'Reflections on the Commercial Litigation Landscape - Lessons From the Past Moving Forward' (2005) 26 Australian Bar Review 145 (observing a growth in 'trolley load litigation' since the mid-1990s).

25 See Michael Legg, Case Management and Complex Civil Litigation (Federation Press, 2011), 17; Martin Meredith, 'Mega-Litigation Tales From Bell, C7 and BCCI - Lessons Still to be Learnt' (2013) (March) Law Society Bulletin 10, 10-11. The fictional case of Jarndyce v Jarndyce, which Charles Dickens presented in 1853's Bleak House as a typical example of a mid-1800s chancery action, surely qualifies as mega-litigation. Jarndyce, a succession case, spanned multiple generations; Dickens explains in Chapter 1 that 'This scarecrow of a suit has, in course of time, become so complicated, that no man alive knows what it means.'

26 Chief Justice Murray Gleeson described American Flange as 'at least as long as the $C 7$ case': Chief Justice Murray Gleeson, 'Some Legal Scenery' (2008) 8 The Judicial Review 415, 420. See American Flange \& Manufacturing Co Inc v Rheem Australia Pty Ltd [1963] NSWR 116; American Flange \& Manufacturing Co Inc v Rheem Australia Pty Ltd [1963] NSWR 1121. 
272 day trial, ${ }^{27}$ the TNT Management case in the mid-1980s; ${ }^{28}$ and, in the 1990s, the Duke Group case in the Supreme Court of South Australia, believed to be the longest trial in Australian history. ${ }^{29}$ In the absence of empirical data, it is not clear that mega-litigation is increasing.

When asked for their impressions about whether mega-litigation was increasing, interview participants were equivocal. Most said mega-litigation had existed before they were appointed to the bench, ${ }^{30}$ although some expressed a tentative view that mega-litigation was becoming more common, ${ }^{31}$ or becoming larger and more complex. ${ }^{32}$ The interview data did not create a strong impression that megalitigation was becoming more common.

This does not, however, mean that the management of mega-litigation is not an important question. I agree with Martin Meredith that whether mega-litigation is increasing

is, to some degree, beside the point. It only takes one mega-case to negatively impact on the civil justice system given the cost, impact on resources and the number of years the impact can last. ${ }^{33}$

A single case of mega-litigation places a great burden on the justice system. Given this, the question of whether mega-litigation is increasing is less important than the question of whether mega-litigation is likely to continue to occur at all. I will answer this question by identifying the causes of mega-litigation, and considering whether these causes are likely to continue to produce mega-litigation in the future.

In Chapter 3, I discussed the factors that mark out a case as mega-litigation: the amount at stake, the resources of the parties, the length of the hearing, the amount of documentation, the number of parties and the complexity of the legal and factual issues. In this section I examine the broader social, legal and cultural factors that

\footnotetext{
$27 \quad$ (1970) 92 WN (NSW) 29.

$28 \quad$ Trade Practices Commission v TNT Management Pty Ltd (1985) 6 FCR 1.

$29 \quad$ Duke Group (in liq) v Pilmer (1998) 73 SASR 64 (471 days).

30 Interview with the Honourable Michael Black AC QC (Melbourne, 22 November 2012); Interview with the Honourable Ray Finkelstein QC (Melbourne, 21 November 2012); Interview with Chief Justice Wayne Martin (Perth, 6 March 2013); Interview with Justice Peter McClellan (Sydney, 5 June 2012); Interview with Participant E.

31 Justice Wayne Martin (Perth, 6 March 2013); Interviews with Participants E and F. Interview with the Honourable Ray Finkelstein QC (Melbourne, 21 November 2012); Interview with Justice Peter McClellan (Melbourne, 5 June 2012).

Meredith, above n 25, 10.
} 
create mega-litigation. Five factors emerge from the literature, and from the interviews conducted for this project. These factors are the complexity of commercial life; the ease with which technology allows documents to be created; the availability of funding for litigation; the content of the substantive law; and the culture of the legal profession. Examination of these factors demonstrates that mega-litigation is likely to persist in years to come.

\section{A Complexity of Commercial Life}

Interview participants and commentators alike have identified the complexity of modern commercial life as a cause of mega-litigation. ${ }^{34}$ There are several reasons why this factor leads to mega-litigation. For one thing, the scale on which commercial transactions are conducted means that the failure of a business venture, or the breach of an agreement, creates a dispute with very high stakes. ${ }^{35}$ Echoes of the collapse of a business empire can be heard in litigation conducted many years after the event. Cases arising out of the late 1980s crash continued well into the $2000 s^{36}$ and the recent global financial crisis might be similarly productive of longrunning litigation.

The complexity of today's business dealings creates legal and factual complexity - a factor which, as discussed in the previous chapter, is a feature of mega-litigation. ${ }^{37}$ Transactions are embodied in dense, intricate legal documents that throw up novel legal issues. Major business agreements are likely to involve multiple parties. This creates legal and factual complexity as each of the relationships between those parties must be examined. It also means there will be multiple parties to any legal dispute over the agreement. In C7, for instance, the plaintiffs alleged that a consortium consisting of News Ltd, Publishing and Broadcasting Ltd (commonly known as 'PBL'), Telstra and Foxtel had entered into an anti-competitive agreement. Not only did this allegation lead to an examination of a complex multi-party agreement, it also brought to the litigation a group of extremely well resourced, and separately represented, parties.

34 Interview with Justice David Harper (Melbourne, 19 November 2012); Interview with Justice Robert McDougall (Sydney, 6 June 2012); Interview with Participant E; Legg, Case Management and Complex Civil Litigation, above n 25, 19; Sackville, 'Mega-Litigation: Towards a New Approach', above n 24, 91; Meredith, above n 25, 14.

35 See Sackville, 'Mega-Litigation: Towards a New Approach', above n 24, 91.

36 Bell Group, which concerned the events of 1989 and 1990, continued well into the second decade of the $21^{\text {st }}$ century. 
Corporate groups are ubiquitous in modern business activity. Some of the most noteworthy cases of mega-litigation have involved the failure of corporate groups. ${ }^{38}$ Unravelling the relationships between the different components of the group makes for a wide-ranging factual enquiry. For example, determining whether a member of a corporate group was insolvent on a particular day might require an examination not only of that company's assets and liabilities, but also of the extent to which it could rely on other members of the group for support, and the likelihood of other members of the group enforcing liabilities against the company. This, in turn, requires an assessment of the financial position of the other members of the group. Bell Group involved a myriad of enquiries of this sort. Litigation involving a corporate group generally involves multiple parties (as each member of the group has separate legal personality), although if the companies in the group share common interests they may share representation.

Globalisation is another feature of modern commerce. Corporate groups can have members in different countries, ${ }^{39}$ and virtually all major companies trade internationally. Where mega-litigation involves international activity, the judge may need to become familiar with some aspects of foreign law or business practice, and there may be choice of law issues. Quite apart from this, there are logistical problems in hearing a case when some of the key players - parties, witnesses or decision-makers within a corporate party - are located overseas. It may be prohibitively expensive and impractical to bring a person to Australia for the duration of a mega-litigation trial. Time zone differences may make it impracticable to take evidence by video link to another country, and this process is neither cheap nor failsafe. ${ }^{40}$ Amazingly, in some cases the most convenient course is for the court, including a judge and several staff, to hear the case in another country for several weeks. ${ }^{41}$ For all these reasons, the 'international element' is a cause of megalitigation. ${ }^{42}$

The complexity of commercial life also means that significant commercial litigation usually requires expert evidence. As Michael Legg points out, mega-litigation commonly involves

\footnotetext{
38 Including the ASIC v Rich, the Bell Group litigation, and Duke Group Ltd (In liq) v Pilmer (1998) 144 FLR 1.

39 This was the case in both ASIC $v$ Rich and Bell Group.

40 For a discussion of the practical difficulties in taking evidence by video link, see Australian Securities and Investments Commission v Rich (2004) 49 ACSR 578, 581-9.

41 For an illuminating discussion of the reasoning that leads to the decision to relocate to another country, see Australian Securities and Investments Commission v Rich (2004) 49 ACSR 578. 
(a) evidence as to technical or scientific issues in intellectual property cases or product liability claims; 43

(b) evidence dealing with disputed economic issues, such as the definition of markets in competition cases; and

(c) evidence from accountants or financial or industry experts in claims for damages. ${ }^{4}$

Expert evidence is, by its nature, expensive to obtain and difficult to understand. In mega-litigation it also tends to be voluminous and productive of arguments about admissibility. In C7, the expert reports ran to '2041 pages of text, plus many hundred pages of appendices, calculations and the like.' ${ }^{45}$ In ASIC $v$ Rich, there were at least six published interlocutory judgments on issues of expert evidence. ${ }^{46}$ '[E]laborate expert evidence' is such a common motif in mega-litigation that it can almost be seen as a characteristic feature of such litigation. ${ }^{47}$

Globalisation, the rise of large corporations, and progressions in the size and complexity of commercial transactions may not be exclusively 21st century phenomena, but their influence has increased dramatically over the last 30 years. Importantly for this discussion of the causes of mega-litigation, commercial life is unlikely to become less complex in the future.

\section{B Technology and Documents}

As discussed in the previous chapter, ${ }^{48}$ Sackville J in C7 identified 'vast quantities of documentation in paper or electronic form' as a characteristic of mega-litigation. ${ }^{49}$ While I concluded that this ought not to form part of the definition of mega-litigation, the proliferation of documents resulting from the use of technology may be a cause of mega-litigation.

43 One might put engineering evidence in the same category. See, eg, Alstom Ltd v Yokogawa Australia Pty Ltd (No 7) [2012] SASC 49.

$44 \quad$ Legg, Case Management and Complex Civil Litigation, above n 25, 95.

$45 \quad$ Seven Network Ltd v News Ltd [2007] FCA 1062, [16].

$46 \quad$ Australian Securities and Investments Commission v Rich [2005] NSWSC 706; Australian Securities and Investments Commission v Rich [2005] NSWSC 650; Australian Securities and Investments Commission $v$ Rich [2005] NSWSC 939; Australian Securities and Investments Commission v Rich [2005] NSWSC 999; Australian Securities and Investments Commission v Rich (2005) 218 ALR 764; Australian Securities and Investments Commission v Rich (2005) 190 FLR 242.

$47 \quad$ Legg, Case Management and Complex Civil Litigation, above n 25, 95.

48 At 30-1.

49 Seven Network Ltd $v$ News Ltd [2007] FCA 1062, [1]. 
One interview participant, Justice Peter McClellan, reflected on the changes he had seen during his career:

When I started at the Bar you rarely got a brief in a spring-back binder. That was rare. Now of course you have trolleys ... I mean, you haven't got a decent case in Sydney unless it's a two trolley case - and maybe more. ${ }^{50}$

Other interview participants reported similar increases in the number of documents involved in litigation. ${ }^{51}$ They put this down to the ease with which documents can be created and replicated using modern technology. ${ }^{52} \mathrm{~A}$ conversation that takes place via email creates a string of electronic documents. A finalised agreement may be preceded by a series of edited drafts. Multiple copies of the same document may be held by different people within an organisation. Each of these documents is potentially discoverable, and potentially subject to tender.

Hand in hand with the explosion of documents has come something of an abdication of responsibility, on the part of lawyers, for sorting and sifting the documents that reach the court. Justice Ken Hayne, speaking extra-judicially, has described the evolution of this process:

There was once a time when the solicitor would choose what he or she thought to be the most relevant documents, have a copy typist copy the text of the documents, and then send those documents with some observations to counsel for an opinion....

The photocopying machine put an end to that. All the documents the solicitor had were copied and sent to counsel. The moment of discriminating between what was important and what was not had moved from the solicitor's office to counsel's chambers....

As our ability to reproduce material digitally penetrated the practice of the law we moved to the so-called e-court in which computer screens proliferated. Everyone in the courtroom could now see the image of the document that was under discussion. ... [T] he consequence was that the moment of discrimination between what matters and what does not was deferred. It was deferred from

50 Interview with Justice Peter McClellan (Melbourne, 5 June 2012). See also Rares, above n 21, 141.

51 Interview with Justice Robert McDougall (Sydney, 6 June 2012); Interview with Participant F.

52 For similar observations, see Justice PA Keane, 'Access to Justice and Other Shibboleths' (Paper presented to JCA Colloquium, Melbourne, 10 October 2009), 25-8; Justice Peter Vickery, 'Managing the Paper: Taming the Leviathan' (2012) 22 Journal of Judicial Administration 51, 52-3, 65-8; Michael Legg, 'Electronically Stored Information and Social Media: Implications for Discovery and Evidence' in Michael Legg (ed), The Future of Dispute Resolution (LexisNexis, 2013) 61. 
counsel's chambers to at least the courtroom [and sometimes] ... from the courtroom to judges' chambers. ...

Now counsel can have everything available on a single disc or memory stick. And most of what appears on that disc or that stick might have some relevance to the issues ... So why choose between the material that can be compressed into this single record? Why not give it all to the judge and see what he or she makes of it? If it is not immediately important, it can all be described as 'useful' background material..$^{53}$

The combination of this 'passive litigation culture'54 with the proliferation of documents contributes to mega-litigation in at least two ways. First, discovery becomes a massively time-consuming and expensive task for the parties. Secondly, the task of the judge is made larger and more difficult by having to navigate their way through a 'blizzard of paper' ${ }^{55}$

The number of paper and electronic documents surrounding any commercial relationship is unlikely to diminish in the future; in fact, as more and more business is conducted electronically the reverse is likely to be the case. In this respect, document-heavy mega-litigation can be described as a 'particularly contemporary product' ${ }^{56}$

\section{Funding Available to Litigants}

As we saw in the previous chapter, mega-litigation is likely to flourish when the parties are willing to spend vast sums of money on the litigation. ${ }^{57}$ The parties may be large, successful corporations with massive resources at their disposal. Additionally, the rise of litigation funding in recent years means more corporations and individuals have access to the resources necessary to participate in large scale litigation.

Litigation funding is an arrangement under which a litigation funder agrees to pay the legal costs of a plaintiff's action, and to bear the risk of paying the other side's costs if the action fails, in return for an agreed share of the proceeds if the action is

53 Justice Kenneth Hayne, 'The Vanishing Trial' (Paper delivered at Supreme and Federal Courts Judges Conference, Sydney, 23 January 2008), 19-20. See also Keane, above n 52, 26-7.

54 Meredith, above n 25 'Mega-Litigation Tales From Bell, C7 and BCCI - Lessons Still to be Learnt' (2013) (March) Law Society Bulletin 10, 14.

$55 \quad$ Federal Court of Australia, Case Management Handbook (13 October 2011), [10.36].

56 Interview with Justice Peter McClellan (Melbourne, 5 June 2012).

$57 \quad$ At $31-2$ and 36. 
successful. ${ }^{58}$ Such arrangements were traditionally impermissible, as they breached the common law prohibitions on maintenance and champerty. ${ }^{59}$ Since the mid1990s, insolvency practitioners have been able to take advantage of an exception to the prohibitions against maintenance and champerty. ${ }^{60}$ This exception led to the creation of litigation funding companies. Other statutory ${ }^{61}$ and common law ${ }^{62}$ developments effectively put an end to the doctrines of maintenance and champerty. As a result, the market for litigation funding has expanded into class actions and single plaintiff lawsuits. ${ }^{63}$ Litigation funding provides access to justice to plaintiffs who would not otherwise be able to afford to litigate. ${ }^{64}$ It can also be used as a risk management tool by companies and individuals who could afford to litigate but would otherwise judge the exercise too uncertain. This means that some very large claims which, but for litigation funding, would be neglected, are being pursued. Commentators and interview participants alike identified the increasing availability of litigation funding as one cause of mega-litigation. ${ }^{65}$ The Productivity Commission has recently recommended that litigation funders be subject to more stringent regulation, while accepting that litigation funders have a continuing role in facilitating access to justice. ${ }^{66}$

58 See Productivity Commission, above n 23, 534; Standing Committee of Attorneys-General, 'Litigation Funding in Australia' (Discussion Paper, May 2006), 4; Law Council of Australia, 'Regulation of Third Party Litigation Funding in Australia' (Position Paper, June 2011), 4 [3]; Damian Grave, Ken Adams and Jason Betts, Class Actions in Australia (Lawbook, $2^{\text {nd }}$ ed, 2012) 786 [17.120].

59 See Grave, Adams and Betts, above n 58, [17.140] 789-90; Standing Committee of AttorneysGeneral, above n 58, 4.

60 See Re Movitor Pty Ltd (in liq) (1996) 64 FCR 380; Grave, Adams and Betts, above n 58, 790-1 [17.150]; Corporations Act 2001 (Cth) ss 420(2)(b) and (g), 477(2)(c).

61 See, eg, Maintenance, Champerty and Barratry Abolition Act 1993 (NSW); Criminal Law Consolidation Act 1935 (SA) sch 11 (inserted in 1992); Civil Law (Wrongs) Act 2002 (ACT) s 221; Crimes Act 1958 (Vic) s 322A; Wrongs Act 1958 (Vic) s 32 (inserted in 1969). See Campbells Cash and Carry Pty Ltd v Fostif Pty Ltd (2006) 229 CLR 386; Mobil Oil Australia Pty Ltd $v$ Trendlen Pty Ltd (2006) 80 ALJR 1503.

63 Law Council of Australia, above n 58, 4 [2].

64 Productivity Commission, above n 23, 538-9; Wayne J Attrill, 'The Future of Litigation Funding in Australia' in Michael Legg, The Future of Dispute Resolution (LexisNexis, 2013) 167. For a discussion of some of the problems with litigation funding, see Keane, above $\mathrm{n} 52$.

65 Interviews with Participant E and Participant G; Meredith, above n 25, 14.

66 Productivity Commission, above $\mathrm{n} 23$, ch 18.2. For a discussion of the regulation of litigation funding in Australia to date, see Office of the Legal Services Commissioner (NSW), The Regulation of Third Party Litigation Funding in Australia: Discussion Paper (March 2012); Attrill, above $n$ 64, 176-9. 


\section{Individualised Justice in the Substantive Law}

Writing extrajudicially in 1995, Chief Justice Murray Gleeson ${ }^{67}$ identified a trend in Australia's substantive law 'towards a preference for individualised, discretionary solutions as against the principled application of general rules' ${ }^{68}$ This trend towards 'individualised justice' ${ }^{69}$ reflected 'the spirit of the times': ${ }^{70}$

The demands of justice, as seen through modern eyes, are much less likely to be met by formal and inflexible rules which treat hard cases with the dismissiveness sometimes manifested in earlier times. The citizens of the late $20^{\text {th }}$ century have an attitude towards all forms of authority which is questioning, demanding and self-assertive. They seem to place less value upon predictability than former generations, and are impatient of what they regard as mere formalism. ${ }^{71}$

This spirit demands that the law be sensitive to the unique circumstances of every legal dispute, rather than setting bright-line rules that may deliver unfair results in some cases. The legislative and judicial response to these demands has been to create new causes of action, or adapt of existing rules, in ways that allow for maximum consideration of the individual circumstances of each case. Examples include the development of the equitable concept of unconscionability, ${ }^{72}$ the statutory prohibition of misleading and deceptive conduct, ${ }^{73}$ and the conferral on courts of discretionary powers to make such orders as are 'fair and equitable' in each case. ${ }^{74}$ Delivering individualised justice requires the court to examine the facts in each case in considerable breadth and depth. Further, the application of 'principle-based regulation rather than more specific rules-based regulation' expands the scope of the arguments that can be made. ${ }^{75}$ Sackville explains how the search for individualised justice can create mega-litigation:

67 Then Chief Justice of the New South Wales Supreme Court.

68 Chief Justice AM Gleeson, 'Individualised Justice - The Holy Grail' (1995) 69 Australian Law Journal 421, 421.

69 Ibid. Gleeson took the term 'individualised justice' from PS Atiyah, 'From Principles to Pragmatism', Oxford University, 17 February 1978 (Clarendon Press) 15. More recently, the Chief Justice of South Australia has reiterated Gleeson's observations about the trend towards individualised justice: Chief Justice John Doyle, 'Imagining the Past, Remembering the Future - the Demise of Civil Litigation' (8 ${ }^{\text {th }}$ Gerard Brennan Lecture, delivered on 24 June 2011 at Bond University, Queensland).

$70 \quad$ Gleeson, 'Individualised Justice', above n 68, 430.

71 Ibid 430.

72 Ibid $425-6$.

$73 \quad$ Ibid 427

$74 \quad$ Ibid 428.

75 Legg, Case Management and Complex Civil Litigation, above n 25, 18. 
The more flexible the principles to be applied by the courts, the broader the scope of admissible evidence and the greater the likelihood of a prolonged hearing. When the relevant principles require findings to be made as to the subjective intentions or motives of particular parties, the scope of the forensic inquiry is likely to be greatly extended and the contest rendered more bitter than otherwise would be the case. ${ }^{76}$

Several interview participants agreed that the complex, flexible content of the substantive law was a factor contributing to mega-litigation. ${ }^{77}$

Not only has the contemporary trend towards individualised justice made the determination of a single cause of action more complex, it has also led to a proliferation of alternative causes of action. A single set of circumstances might give rise to actions in contract, equity and tort as well as constituting a potential breach of corporations, competition and consumer legislation. As the causes of action multiply, the complexity of the litigation increases, as one interview participant explained:

You'll have the same set of facts giving rise ... to multiple causes of action, giving rise to different assessments of damage, giving rise to different forms of relief. And [litigants] are reluctant, understandably, to give up any of those because they will give different results. ${ }^{78}$

Complexity in the law is nothing new. However, the trend towards individualised justice since at least the early 1990s has broadened the scope of both the factual inquiry and the legal arguments in any single action. This is a recipe for factual and legal complexity which, as explained in Chapter $3,^{79}$ is an outstanding feature of mega-litigation.

\section{E Culture of the Legal Profession}

The attitude of lawyers is a perennial theme in discussions of the cost, complexity and delay involved in litigation. Legg points to 'adversarialism' as a cause of complex litigation:

[T]he taking of every point within the litigation and a lack of cooperation between the lawyers can cause the contentiousness of the case to result in the need for greater evidence (every point must be proved rather than non-core

\footnotetext{
76 Sackville, 'Mega-Litigation: Towards a New Approach', above n 24, 92.

77 Interview with Justice David Harper (Melbourne, 19 November 2012); Interview with Justice Robert McDougall (Sydney, 6 June 2012); Interviews with Participants E, F, G and H.

78 Interview with Participant E. 
issues agreed), a larger range of claims and associated legal issues so that the size of the litigation increases. ${ }^{80}$

Complaints about the mindset of lawyers are nothing new. In Bleak House, Charles Dickens delivered the following indictment of the mid-19th century legal profession:

The one great principle of the English law is to make business for itself. There is no other principle distinctly, certainly, and consistently maintained through all its narrow turnings. Viewed by this light it becomes a coherent scheme, and not the monstrous maze the laity are apt to think it. Let them but once clearly perceive that its grand principle is to make business for itself at their expense, and surely they will cease to grumble. ${ }^{81}$

In a series of articles written 140 years later, 82 Adrian Zuckerman reached an unsettlingly similar conclusion. The landmark Woolf reforms to English civil procedure, ${ }^{83}$ which included 'sanctions against wasteful procedural posturing' were, Zuckerman argued,

bound to be ineffectual, if the incentives for such behaviour are not removed at the same time. The forensic practices of the legal profession are, inevitably, bound up with the profession's financial interest in litigation. Accordingly, as long as practitioners are paid by the hour or by the day, they will continue to have an interest in ... expanding the litigation process. ${ }^{84}$

Interview participants spoke about the culture of the legal profession as a cause of mega-litigation. Peter McClellan observed

a failure in the legal profession to discipline the issues which are litigated, make judgments about what's a good issue and what's a bad issue. And the increasing tendency is to throw every issue into the pool, which I think is a failing in the profession. ${ }^{85}$

80 Legg, Case Management and Complex Civil Litigation, above n 25, 20.

81 Charles Dickens, Bleak House (1853) Ch XXXIX.

82 AAS Zuckerman, 'Reform in the Shadow of Lawyers' Interests' in AAS Zuckerman and Ross Cranston (eds), Reform of Civil Procedure: Essays on 'Access to Justice' (Clarendon Press, 1995) 61;

Adrian AS Zuckerman, 'Justice in Crisis: Comparative Dimensions of Civil Procedure' in Adrian AS Zuckerman (ed), Civil Justice in Crisis (Oxford University Press, 1999) 3, 44-5; AAS Zuckerman, 'A Reform of Civil Procedure - Rationing Procedure Rather than Access to Justice ' (1995) 22 Journal of Law and Society 155; AAS Zuckerman, 'Lord Woolf's Access to Justice: Plus ça change...' (1996) 59 Modern Law Review 773.

83 Lord Woolf, Access to Justice: Final Report (1996); Lord Woolf, Access to Justice: Interim Report (June 1995). For a summary of the effect of the Woolf reforms see JA Jolowicz, On Civil Procedure (Cambridge University Press, 2000), Ch 19.

84 Zuckerman, 'Reform in the Shadow of Lawyers' Interests', above n 82, 76-7.

85 Interview with Justice Peter McClellan (Melbourne, 5 June 2012). 
Justice Robert McDougall, drawing on his experience as both a judge and a lawyer in mega-litigation, described the 'battlefield mentality' that can develop within a legal team. Lawyers working on a mega-litigation matter, he explained,

normally form a team: a few partners, some senior associates and a tribe of people down the food chain to do the work. And because they're working full time on this you do get that closed circle mentality. ... And so some people come to identify more than perhaps they should with the client and the justice of the client's cause. And I do think the increasing tendency to use barristers ... as members of the team contributes in some ways to that, because the barrister just doesn't come in and take an independent look and say 'this is crap, get rid of it'. They're drawn in as part of the team doing the work ... It's good that [the barrister is] involved in preparing the case ... but you don't always have someone with that independent detachment looking at the case and saying 'come on, it's crazy, what are you doing?'s6

While there is support in the literature, as well as in the interview data, for the view that lawyers contribute to the creation of mega-litigation, other views exist. Some interview participants had presided over mega-litigation in which the legal representatives were highly efficient, cooperative and reasonable. ${ }^{87}$ Adversarialism and the 'battlefield mentality' may contribute to some (perhaps many) cases of mega-litigation, but they are not a necessary condition for the existence of megalitigation. Therefore, while I agree that lawyers can contribute to the complexity of litigation, I would not overstate the significance of this factor. Even with the most conciliatory, self-sacrificing legal profession imaginable, the other factors discussed in this section are capable of creating mega-litigation.

The discussion in this section demonstrates that mega-litigation is caused by a combination of factors, including the complexity of contemporary business and law; the number of documents generated by technology; the availability of funds for litigation, and the attitude of lawyers. The modern social, economic and legal landscape is conducive to each of these factors. Mega-litigation, therefore, is likely to continue to occur in the future.

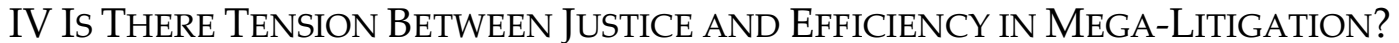

So far in this chapter I have demonstrated that mega-litigation places burdens on the justice system that are likely to persist in the future. The issue with which this thesis deals is not simply how to make mega-litigation more efficient; it is how to reconcile the need for efficiency with the court's obligation to do justice in each case. Before

\footnotetext{
86 Interview with Justice Robert McDougall (Sydney, 6 June 2012).

87 Interviews with Participants B, D, E and F.
} 
going further, I will test the assumption that there will, in some cases, be tension between these objectives in mega-litigation.

In the course of the interviews conducted for this project, some participants reported that they had observed tension between justice and efficiency in mega-litigation. Some acknowledged this explicitly (when asked); ${ }^{88}$ others did so implicitly, when speaking about the need to balance the demands of an individual case against other objectives. ${ }^{89}$ Participants spoke about reducing the time and cost involved for the parties (what I termed in Chapter 2 'party efficiency'); 90 using public resources responsibly ('public efficiency'); ${ }^{91}$ and being mindful of the needs of other litigants and would-be litigants ('public justice').92 All of these were seen as legitimate aims of civil procedure. A common observation was that 'perfect' or 'Rolls Royce' ${ }^{93}$ justice was not a realistic aim; such a standard was seen as either unattainable, or unjustified in light of the other aims of civil procedure:

It's no use having perfect justice if, in practical terms, no-one can access it. ... There's no perfect justice, that's the point. ... Trials that take 10, 12 months to resolve, [with] issues that really you could and should resolve in two weeks that's not perfect justice; it's not really justice at all, it's just silly. ${ }^{94}$

Interview with Justice David Harper (Melbourne, 19 November 2012); Interview with Chief Justice Wayne Martin (Perth, 6 March 2013); Interview with the Honourable Neville Owen (King's Park, WA, 5 March 2013). Interviews with Participants A and F.

90 Interview with Justice David Bleby (Adelaide, 16 February 2012), above n 13; Interview with Participant E.

91 Interview with the Honourable Michael Black AC QC (Melbourne, 22 November 2012); Interview with Justice David Bleby (Adelaide, 16 February 2012); Interview with Chief Justice Wayne Martin (Perth, 6 March 2013); Interview with Justice Peter McClellan (Melbourne, 5 June 2012); Interviews with Participant B. Interview with the Honourable Michael Black AC QC (Melbourne, 22 November 2012); Interview with the Honourable Ray Finkelstein QC (Melbourne, 21 November 2012); Interview with Justice David Harper (Melbourne, 19 November 2012); Interview with Justice Peter McClellan (Melbourne, 5 June 2012); Interviews with Participants A, B, F and H.

93 The 'Rolls Royce' analogy is often used in civil procedure literature to refer to the highest possible standard of procedural justice. The term sometimes conveys the slightly derogatory implication that this is an extravagant and unrealistically high standard. See, eg, Michael Lavarch, 'Fighting the Fiends From Finance' in Helen Stacy and Michael Lavarch (eds), Beyond the Adversarial System (Federation Press 1999) 10, 16; Australian Law Reform Commission, Managing Justice: A Review of the Federal Civil Justice System, Report No 89 (2000), [1.87]. Interview with the Honourable Michael Black AC QC (Melbourne, 22 November 2012). 
I do not believe in perfect justice, being we cannot afford it. ... Rolls Royce treatment is usually not appropriate. Even for the parties who can afford it, it should be abandoned because it ruins the system for everybody else. ${ }^{95}$

One thing we have learnt in the last ten years is you just can't have open-ended justice, in other words that everything goes ahead without regard to the cost and the expense and the efficiency of the litigation. ${ }^{96}$

Everyone can't get Rolls Royce treatment, or the system will bog down. ${ }^{97}$

Do we really need that level of perfect justice, given that the cost ... is discouraging people from opening the door to the court at all? So when the cost and the delay ... become so prohibitive that people stay away from the system then you say 'how robust can we afford to be, in terms of accepting a result that may be skewed by inadequate factual information?' ... How perfect does it have to be? ${ }^{98}$

Comments of this sort reflect a belief that the parties are not entitled to perfect justice: the interests of the parties must sometimes be compromised in order to achieve other objectives. This is a crucial point for this thesis. It indicates, first, that civil procedure has the multiple goals discussed in Chapter 2; and secondly that judges must work out how to reconcile these goals when they conflict.

Reported procedural decisions in mega-litigation provide further evidence of the tension that can arise between different objectives of civil procedure in megalitigation. Consider the following illustrations.

In November 1997, the case managing judge (Carr J) in the Bell Group litigation listed the matter for trial beginning in August 1998. ${ }^{99}$ In May 1998, the applicants applied for the start of trial to be adjourned to 16 February 1999. There were two reasons for this application. The first was that the applicants were not going to complete their preparation in time for an August 1998 trial. ${ }^{100}$ The second was that, since the matter had been listed for trial, the respondents had been granted leave to amend their defence in a way that raised significant new issues. The applicants said that they would not be ready to respond to these issues by August. ${ }^{101}$ This application clearly raised the tension between justice and efficiency in mega-litigation. On the

\footnotetext{
95 Interview with the Honourable Ray Finkelstein QC (Melbourne, 21 November 2012).

96 Interview with Participant D.

97 Interview with Participant $\mathrm{H}$.

$98 \quad$ Interview with Chief Justice Wayne Martin (Perth, 6 March 2013).

99 The matter was, at that time, in the Federal Court. It was later transferred to the Supreme Court of Western Australia.

$100 \quad$ See Bell Group Ltd (in liq) v Westpac Banking Corporation (1998) 86 FCR 215, 226.

101 Ibid.
} 
efficiency side of the equation, the trial needed to get underway as soon as possible. It would inevitably be a long trial that would place great demands on the parties and the court system. The sooner the trial was commenced, the sooner it would be finished. But considerations of justice between the parties suggested a different conclusion. If the Court was to determine the issues raised in the amended defence on their merits, the applicants would need more time to prepare their case. Otherwise, the Court would receive incomplete arguments and evidence on those issues. Furthermore, it seemed unfair to force the applicants to meet the new issues raised in the amended defence without having had adequate time to prepare their response. ${ }^{102}$

A second example of the tension between justice and efficiency in mega-litigation arose in ASIC $v$ Rich. Two important witnesses resided in England and were unwilling, though not unable, to come to Australia to give evidence. Three options presented themselves: the Court could travel to London to take the evidence, at enormous expense; evidence could be taken by audio-visual link, which would be almost as expensive and would create practical difficulties; or the evidence could be omitted. Efficiency - and, arguably, public justice - favoured the third option. But justice between the parties suggested that the evidence must be taken, no matter how 'extravagant' the process. ${ }^{103}$

A third example comes from the $C 7$ case. On the 90th day of trial, the plaintiffs applied to amend their statement of claim. The effect of the amendment would have been to expand the scope of one of the claims against Optus. ${ }^{104}$ By this time, all the lay witnesses had completed their evidence and the expert evidence was underway. In order to respond to the expanded allegations, Optus would need to recall some of the lay witnesses, and possibly arrange some further expert reports. Efficiency considerations militated against allowing the amendment. But doing justice

102 Carr J granted a one month adjournment but refused the five month adjournment sought by the applicants. On appeal, in a judgment which places a high priority on doing justice between the parties, the Full Federal Court vacated the trial date and ordered that the trial not commence before 1 February 1999: Bell Group Ltd (in liq) v Westpac Banking Corporation (1998) 86 FCR 215. In fact, the trial did not commence until July 2003, after being transferred to the Supreme Court of Western Australia.

103 Australian Securities and Investments Commission v Rich (2004) 22 ACLC 1125, 1137. Austin J determined that the Court would go to London. He acknowledged (at 1137) that following the witnesses to their place of residence 'might seem bizarre or extravagant. But if the evidence is central enough, and audiovisual evidence is not feasible, and the witnesses cannot be persuaded to [co-operate] ... there is no alternative but to do so.' On a similar issue, see Bell Group Ltd (in liq) $v$ Westpac Banking Corporation (No 3) [2004] WASC 93. 
between the parties required all issues in dispute between the parties to be fully agitated. ${ }^{105}$

These examples demonstrate the potential for the aims of justice and efficiency to come into conflict in mega-litigation. This tension can manifest itself in a wide range of procedural decisions - decisions, for example, about whether to place limits on the length of written submissions; ${ }^{106}$ whether to give summary judgment when a case appears weak; ${ }^{107}$ whether to combine the hearing of multiple related proceedings; ${ }^{108}$ whether to grant an adjournment ${ }^{109}$ or an extension of time. ${ }^{110}$

Three interview participants reported that they had not experienced any tension between justice and efficiency in mega-litigation. ${ }^{111}$ One Supreme Court judge, when asked whether this tension ever arose, replied:

No not really. The reality is you've got to do justice first and efficiency takes care of itself. It's important that you try and record everything and deal with all the issues that have been raised but you have to bear in mind that we are a trial division. We are not trying to make the law, we... just need to apply the law to the facts. I think we've just got to keep sight of that. That breeds its own efficiency at the end. ${ }^{112}$

Former Federal Court Justice Malcolm Lee, when asked the same question, gave a similar answer:

No. No, not really. The efficiency is in the early phase, getting things done quickly with the directions. But once you got to the trial element, the issues were there to be decided, it wasn't as though something had been shorn off improperly. So then you just turned your mind to the material that was presented to you, and the arguments that were put up. ${ }^{113}$

These participants certainly did not disregard efficiency considerations; they simply did not see efficiency measures as inconsistent with justice. This may indicate that

105 Sackville J refused to grant the amendment, based on the unfairness to Optus of changing the case it had to meet. The option of adjourning the trial to allow Optus to prepare a response was considered simply impracticable. Seven Network Ltd v News Ltd (No 16) [2006] FCA 574.

106 See, eg, Australian Securities and Investments Commission v Rich (2009) 236 FLR 1, 28 [51].

$107 \quad$ See, eg, Seven Network Ltd v News Ltd (No 4) (2005) 214 ALR 686.

108 See, eg, Bell Group Ltd (in liq) v Westpac Banking Corporation (No 3) [2004] WASC 93.

109 See, eg, Australian Securities and Investments Commission v Rich [2006] NSWSC 266.

110 See, eg, Australian Securities and Investments Commission v Rich [2007] NSWSC 39.

111 Interview with the Honourable Malcolm Lee QC (Fremantle, 6 March 2013); Interviews with Participants D and E.

112 Interview with Participant D.

113 Interview with the Honourable Malcolm Lee QC (Fremantle, 6 March 2013). 
these participants felt they had found a satisfactory way of reconciling the demands of efficiency and justice. ${ }^{114}$

For one Federal Court judge, the key lay in s 37M of the Federal Court of Australia Act 1976 (Cth). Section 37M provides that the overarching purpose of the civil procedure provisions of the Act is to facilitate the just resolution of disputes according to law, and as quickly, inexpensively and efficiently as possible. ${ }^{115}$ This participant saw s $37 \mathrm{M}$ as setting the 'playing field' for the litigation. ${ }^{116}$ With all parties working towards the common objective set out in s $37 \mathrm{M},{ }^{117}$ this participant saw no compromise between efficiency and justice:

What I ask is 'what are you giving up in order to achieve that objective?' I don't know the answer to that. Everyone's entitled to have their litigation heard and determined. But they are entitled subject to an obligation. And the obligation is that they ... agree to conduct their litigation in accordance with 'quickly, inexpensively and efficiently'. Well, I don't know what the compromise is then. I don't understand what you're giving up if everyone is working to that objective. ${ }^{118}$

I return to the importance of the overarching purpose provisions in Chapter $10 .{ }^{119}$ For now, it is sufficient to note that those participants who said there was no tension between the aims of civil procedure seemed to have reached conclusions about the relationship between those aims. This, in itself, is revealing. Rather than indicating that the relationship between justice and efficiency in mega-litigation is a non-issue, it suggests some possible answers to the question of how to reconcile these different aims. As discussed in Chapter 2,120 the different objectives of civil procedure are not inevitably conflicting. They may, in some circumstances, be complementary. I will explore these issues throughout this thesis. ${ }^{121}$

\footnotetext{
114 The ways in which judges reconcile the objectives of efficiency and justice are explored in detail in Chapter 10.

115 See the discussion of 'overarching purpose' provisions in Chapter 7.

116 Interview with Participant E.

117 Section 37P of the Act obliges parties and their lawyers to act consistently with the overarching purpose.

Interview with Participant E.

At 213-17.

At 23.

See especially Ch 10 sections II and III.
} 


\section{CONCLUSION}

Mega-litigation is caused by a combination of factors. These factors are not exclusively contemporary. There have always been complaints about lawyers unnecessarily prolonging proceedings; there has always been high stakes litigation; there have always been complex laws. However, today's social, legal and economic environment draws together ideal conditions for the birth of mega-litigation: largescale, multi-party business relationships; complex, overlapping statutory and common law causes of action; new sources of funds for would-be litigants; a legal profession with little interest in narrowing the scope of disputes; and an unprecedented capacity for the production and distribution of paper. There is no sign of any of these conditions diminishing in the foreseeable future. Mega-litigation is here to stay.

Mega-litigation brings with it the dilemma at the heart of this thesis: how to reconcile the court's duty to do justice in each case with the need to take into account the interests of the public in both access to justice and efficient use of public resources. In this chapter I have explained why this issue is important. Megalitigation is not just a matter for the parties; it is a problem for the justice system and the community. Each case of mega-litigation will place enormous demands on the judge hearing the case, and on the court system as a whole. Finding ways to deal with mega-litigation efficiently is a priority for the justice system. When courts deal with mega-litigation, it is not enough to consider only the interests of the parties; considerations of public justice and public efficiency come into play. As explained in Chapter 2, these considerations are distinct from, and may conflict with, one another. This conflict is not merely theoretical; as explained in this chapter, it is a practical problem which judges presiding over mega-litigation regularly confront.

This chapter completes Part I of the thesis. The purpose of Part I was to explain the problem with which this thesis deals: the relationship between justice and efficiency in mega-litigation. Having established the existence of a problem, in Part II of this thesis I begin the search for some solutions. Part II explores some approaches to the relationship between justice and efficiency in civil procedure generally (as opposed to in the specific context of mega-litigation). Chapter 5 introduces some of the leading theories on procedure, while Chapters 6 and 7 provide an overview of the development of the law of civil procedure in Australia. 


\section{PART II:}

\section{APPROACHES}

TO THE

PROBLEM 


\section{Chapter 5: Justice And EfFiciency in Civil Procedure: Theoretical PeRspectives}

\section{INTRODUCTION}

Nothing is of more immediate practical importance to a lawyer than the rules that govern his or her own strategies and maneuvers; and nothing is more productive of deep and philosophical puzzles than the question of what those rules should be. ${ }^{1}$

This thesis examines the relationship between justice and efficiency in one context: mega-litigation. Much has been written about this relationship in the broader context of civil procedure and, indeed, in court procedure generally. Part II of this thesis brings together some of the insights from this broader context in order to inform the discussion of justice and efficiency in mega-litigation that follows in Part III. Part II begins, in this chapter, by considering the relationship between justice and efficiency at a high level of generality. This chapter is devoted to theoretical perspectives on justice and efficiency in procedure. Chapters 6 and 7 examine similar issues, but in a practical setting. Chapter 6 provides an overview of the dominant trends in civil procedure in common law countries over the last 150 years, demonstrating a series of shifts in thinking about the objectives and priorities of civil procedure. In Chapter 7 my focus narrows further, to an examination of Australian civil procedure over the last 20 years. Together, these chapters provide the theoretical, doctrinal and practical background against which procedure in megalitigation operates today.

In this chapter, I introduce some of the leading theories on the relationship between justice and efficiency in court procedure generally. These exemplar theories provide some useful ways of thinking about the relationship between justice and efficiency. The remaining chapters of the thesis consider how judges deal with this relationship in practical situations. We will see that some of the ideas introduced in the present chapter are reflected in practice.

I examine four theories of civil procedure in this chapter. I begin with the work of Adrian Zuckerman, one of the most prominent contemporary scholars of procedure. Zuckerman advocates an approach to procedure that balances the competing objectives of accuracy, cost and time. I then move on to consider the contributions made by two giants of legal theory: Richard Posner and Ronald Dworkin. As one might expect, given their respective bodies of work, these two scholars have very

Ronald Dworkin, A Matter of Principle (Clarendon Press, 1986) 72. 
different ideas about the relationship between justice and efficiency in procedural law. For Posner, procedure can be the subject of an economic cost/benefit analysis which weighs the costs of erroneous judicial decisions against the costs of providing court procedure. Dworkin rejects the suggestion that justice can be traded off against efficiency. He accepts that some compromise is inevitable, but argues that there is a guaranteed minimum level of procedure which courts must provide in order to accord proper respect to legal rights. The fourth theory presented in this chapter is that of Robert Summers, who suggests that procedure should be evaluated not only by its results - such as cost or accurate decisions - but also by the 'process values' it embodies.

This chapter provides a brief outline of each theory, together with some critiques. I evaluate the theories on the basis of their practical value. If a judge were faced with a procedural decision in which the objectives of justice and efficiency (from the point of view of either the parties or the public) came into conflict, what assistance could these theories provide?

\section{ZUCKERMAN: THREE DIMENSIONS OF JUSTICE}

Zuckerman's theory of procedure proceeds from the assumption that '[a]ll systems of procedure seek to do justice'. ' 'Justice', for Zuckerman, 'has three dimensions by which it is measured.' ${ }^{3}$ These dimensions are rectitude (or accuracy) of decision; time; and cost.

Zuckerman acknowledges that upholding the substantive legal rights of the parties is the 'most basic' requirement of any legal system. ${ }^{4}$ He refers to Bentham's theory that 'the direct end of procedure is rectitude of decision, that is, the correct application of the substantive law to the true facts. ${ }^{5}$ Accuracy is therefore an important aim of any system of procedural law. But Zuckerman argues that accuracy cannot be the only aim of procedure: '[a]ccuracy need not be bought at any cost nor is it the sole criterion by which we judge the justice and the effectiveness of

$2 \quad$ Adrian AS Zuckerman, 'Justice in Crisis: Comparative Dimensions of Civil Procedure' in Adrian AS Zuckerman (ed), Civil Justice in Crisis (Oxford University Press, 1999) 3, 3.

$3 \quad$ Ibid. See also Adrian Zuckerman, 'Litigation Management Under the CPR: A Poorly-Used Management Infrastructure' in Deirdre Dwyer (ed), The Civil Procedure Rules Ten Years On (Oxford University Press, 2009) 89, 90; Adrian Zuckerman, Zuckerman on Civil Procedure: Principles of Practice (Sweet and Maxwell, $2^{\text {nd }}$ ed, 2006) 3-6.

$4 \quad$ Zuckerman, 'Justice in Crisis', above n 2, 4-7.

5 AAS Zuckerman, 'Quality and Economy in Civil Procedure: The Case for Commuting Correct Judgments for Timely Judgments' (1994) Oxford Journal of Legal Studies 353, 354, referring to Principle of Judicial Procedure, in Collected Works of Jeremy Bentham, Bowring ed, 1938-43, vol II; see also Zuckerman, 'Justice in Crisis', above n 2, 3-4. 
civil procedure.' ${ }^{6}$ Two other 'dimensions' of justice must be taken into consideration: time and cost.

Time is relevant to achieving justice for two reasons. First, delay may undermine the rectitude of a decision because evidence needed to determine the true facts may become unavailable or less reliable with the passing of time. Physical evidence may deteriorate; the memory of witnesses may fade or be replaced by reconstruction; witnesses may even die before trial. ${ }^{7}$ Secondly, the passage of time may 'erode the utility' of the court's determination of the parties' rights. ${ }^{8}$ There are cases in which delay would defeat the purpose of litigation, even if the result is unarguably correct in fact and law. Zuckerman gives the examples of a plaintiff who wishes to have their name reinstated on the electoral roll in time for an election ${ }^{9}$ and of a person wishing to obtain a passport in order to attend a particular overseas event. ${ }^{10}$ For those plaintiffs, a judgment in their favour, no matter how accurate, will be virtually useless if it comes too late. To give another example, the wrong done to a permanently incapacitated personal injury victim is not redressed if that person has to wait many years before receiving compensation and must, in the meantime, live without adequate income or medical care. ${ }^{11}$ A system of procedural law that permits such consequences fails to achieve a crucial object of the legal process: what Zuckerman describes as 'putting things right'. ${ }^{12}$

The matters that make time relevant to justice, then, relate to the interests of the parties. When Zuckerman considers the 'cost dimension', however, further interests come into play. For one thing, governments cannot be expected to provide the justice system with unlimited resources. To Zuckerman,

Zuckerman, 'Quality and Economy', above n 5, 386.

Zuckerman, Zuckerman on Civil Procedure, above n 3, 11; Zuckerman, 'Justice in Crisis', above $n$

2, 6; Zuckerman, 'Quality and Economy', above n 5, 360.

$8 \quad$ Zuckerman, 'Justice in Crisis', above n 2, 6-7.

9 Zuckerman, Zuckerman on Civil Procedure, above n 3, 11; Zuckerman, 'Quality and Economy', above $n$ 5, 360 .

10 Zuckerman, 'Justice in Crisis', above n 2, 6. Zuckerman acknowledges that, while delay is likely to have a greater effect on plaintiffs, it also has adverse consequences for defendants. For instance, a defendant's ability to arrange their finances or to alienate property the subject of a claim may be affected by pending litigation: Zuckerman, 'Quality and Economy', above n 5, 362.

11 Zuckerman, Zuckerman on Civil Procedure, above n 3, 11; Zuckerman, 'Justice in Crisis', above n 2, 6; Zuckerman, 'Quality and Economy', above n 5, 361; Zuckerman, 'Litigation Management Under the CPR', above n 3, 91.

12 Zuckerman, 'Justice in Crisis', above n 2, 7; Zuckerman, 'Quality and Economy', above n 5, 361. 
It is clearly counter-intuitive to suggest that the State ought to design the most accurate civil procedure regardless of cost, when the State need not provide, regardless of cost, the most effective health service or, indeed, almost any other public benefit. ${ }^{13}$

It must therefore be accepted that 'procedural resources are finite', ${ }^{14}$ that state resources are needed for social goals external to the legal system, ${ }^{15}$ and we cannot expect the state to provide justice at any cost. Compromises in the quality or quantity of procedure provided by the State are inevitable. ${ }^{16}$ To use a term introduced in Chapter 2 of this thesis, 'public efficiency' forms part of Zuckerman's cost dimension of justice.

Zuckerman explains that cost also has implications for access to justice. ${ }^{17}$ High litigation costs may prevent people from accessing the courts. But reducing court fees, or increasing legal aid, shifts the cost burden to the taxpayer. ${ }^{18}$ Zuckerman suggests that costs could sensibly be limited by a notion of 'proportionality' between, on the one hand, the complexity of a case and the amount in dispute and, on the other, the procedural steps available to the parties. ${ }^{19}$ He asks 'whether it is really better to offer high quality justice to a few, rather than dispense justice, albeit of lesser quality, to a wider segment of society.' ${ }^{20}$

These three 'dimensions of justice' - accuracy, time and cost - will sometimes 'pull in different directions and call for compromises.' ${ }^{21}$ On this view, accuracy must sometimes be compromised in order to promote other objects of the legal process (such as access to justice and the utility of judgments) or 'in order to free resources for the purpose of achieving external social goals, such as improvements in health or

13 Zuckerman, 'Quality and Economy', above n 5, 354; see also Zuckerman, 'Justice in Crisis', above n 2, 8 .

14 AAS Zuckerman, 'A Reform of Civil Procedure - Rationing Procedure Rather than Access to Justice' (1995) 22 Journal of Law and Society 155, 158.

15 Zuckerman, 'Quality and Economy', above n 5, 386.

16 Zuckerman, 'A Reform of Civil Procedure', above n 14, 161.

17 Zuckerman, 'Justice in Crisis', above n 2, 9; Zuckerman, 'Quality and Economy', above n 5, 354, 361; Zuckerman, 'A Reform of Civil Procedure', above n 14, 161.

18 Zuckerman, 'Justice in Crisis', above n 2, 9.

19 Zuckerman, 'A Reform of Civil Procedure', above n 14, 158-60. The concept of proportionality is captured in a package of recent reforms in the UK in response to the Jackson Report (Lord Justice Jackson, Review of Civil Litigation Costs: Final Report (2009)).

20 Zuckerman, 'A Reform of Civil Procedure', above n 14, 161.

21 Zuckerman, 'Justice in Crisis', above n 2, 3. 
transport services.'22 To Zuckerman, procedural law should aim to strike the 'optimal compromise' between the three dimensions of justice. ${ }^{23}$

In short, Zuckerman invites procedural decision-makers to weigh up the dimensions of justice against one another. Zuckerman's framework is a useful tool for evaluating procedure. But it is silent on just how the 'optimal compromise' is to be reached. How are judges to decide when to sacrifice accuracy to save time? When will increased accuracy outweigh an increase in cost? Within Zuckerman's framework, the answer to questions such as these appears to depend on the impressions and priorities of the relevant decision-maker. ${ }^{24}$

\section{POSNER: ECONOMIC ANALYSIS OF CIVIL PROCEDURE}

The substantial body of literature on the economic analysis of civil procedure ${ }^{25}$ offers a method of analysing procedure which is guided by objective, rather than intuitive, principles. Posner's work is the leading example of this approach. For Posner, the aim of procedural law is 'the minimization of the sum of two types of costs': 'error costs' and 'direct costs' ${ }^{26}$ Error costs flow from a failure to reach the correct result in a case. They are the costs of failing to give effect to the substantive law. If an aim of the substantive law is to increase economic efficiency, then a mistaken imposition or denial of liability will reduce efficiency and thereby result in a social cost. ${ }^{27}$ Direct costs are those incurred by the parties and the state as a result of litigation. They include 'the time of lawyers, litigants, witnesses, jurors, judges, and other people,

22 Zuckerman, 'Quality and Economy', above n 5, 386.

23 Zuckerman, 'A Reform of Civil Procedure', above n 14, 161.

24 In introducing a volume presenting perspectives on civil procedure from 13 different countries, Zuckerman explains that the purpose of applying his conceptual framework is not to grade those different systems in order of preference. Instead, the framework draws attention to the different ways in which different systems 'seek to achieve the goals of justice'. This analysis reveals that 'what lies behind different methods of doing justice is really a difference in priorities': Zuckerman, 'Justice in Crisis', above n 2, 3.

25 See Geoffrey P Miller, 'Introduction: Economic Analysis of Civil Procedure' (1994) 23 Journal of Legal Studies 304, 304, introducing a special issue of the Journal of Legal Studies on this subject and referring to many of the major works in this area.

26 Richard A Posner, 'An Economic Approach to Legal Procedure and Judicial Administration' (1973) 2 Journal of Legal Studies 399, 399; Richard A Posner, Economic Analysis of Law (Little, Brown and Company, $2^{\text {nd }}$ ed, 1972), 429. In the most recent edition of the latter work, Posner drops the phrases 'error costs' and 'direct costs' but still describes 'two types of cost': 'the cost of erroneous judicial decisions' and 'the cost of operating the procedural system': Judge Richard A Posner, Economic Analysis of Law (Wolters Kluwer, $7^{\text {th }}$ ed, 2007) 593. For convenience, in this thesis I will use the terms 'error costs' and 'direct costs'.

27 Posner, 'An Economic Approach', above n 26, 400-1; Posner, Economic Analysis of Law (2007), above $n$ 26, 593 . 
plus paper and ink, law office and court house maintenance, telephone service, etc.' ${ }^{28}$ Having identified these two types of cost, procedure can be evaluated by calculating the sum of error costs and direct costs. Posner provides a simple example of how this calculation works:

Suppose the expected cost of a particular type of accident is $\$ 100$ and the cost to the potential injurer of avoiding it is $\$ 90 \ldots$. [T] he potential injurer ... will avoid the accident - assuming the [law] is administered accurately. But suppose that in 15 percent of the cases in which an accident occurs, the injurer can expect to avoid liability because of erroneous factual determinations by the procedural system. Then the expected costs of the accident to him will fall to $\$ 85$, and since this is less than the cost of avoidance to him (\$90), the accident will not be prevented. ${ }^{29}$

This scenario results in a social loss of $\$ 10$ because the cost of the accident $(\$ 100)$ is incurred rather than the cost of avoiding the accident (\$90). Taking only 'error costs' into account, then, it makes economic sense to improve the accuracy of procedure. The analysis changes, though, when 'direct costs' are included:

We must not ignore the cost of operating the procedural system. Suppose that to reduce the rate of erroneous failures to impose liability from 15 percent to below 10 percent would require an additional investment in procedure of \$20 per accident. Then we should tolerate the 15 percent probability of error, because the cost of error $(\$ 10)$ is less than the cost necessary to eliminate it. ${ }^{30}$

As this example illustrates, the economic approach does not prioritise one goal of procedure over another: the lower the overall cost, the better the procedure. ${ }^{31}$

The economic analysis of civil procedure provides a method for resolving the tension between justice and efficiency in a way that is analytical rather than 'visceral'. ${ }^{32}$ But the approach does not provide a complete solution to the problem. For one thing, it would clearly be impractical for a judge, when making a discrete procedural decision, to engage in an economic analysis of the effects of the decision. Take for instance a decision on an application to expand the scope of discovery to include categories of indirectly relevant documents. To apply an economic analysis to this decision, the judge would have to know the social cost of reaching the

\footnotetext{
28 Posner, 'An Economic Approach', above n 26, 401.

29 Posner, Economic Analysis of Law (2007), above n 26, 593.

30 Ibid (citations omitted).

31 '[I]n general we would not want to increase the direct costs of the legal process by one dollar in order to reduce error costs by 50 (or 99) cents': Posner, 'An Economic Approach', above n 26, 401. 
incorrect result in the case; the likely contribution of the extended discovery to reducing the risk of error; and the direct costs that would be incurred by the parties and the court if the discovery were to go ahead. Not only are these calculations likely to be extremely complex, but they would also require an extraordinary degree of foresight. For these reasons, the economic analysis is more useful as a method of formulating general principles of procedure rather than as a tool for making individual procedural decisions. In fact, Posner appears to envisage economic theory being applied to the design of procedural rules rather than the making of individual procedural decisions. ${ }^{33}$

A more fundamental critique of the economic approach is that it ignores certain values which are important to the civil justice system. Michael Bayles points out that

[o]ne can reasonably be concerned about the fairness as well as total cost of legal procedures. A process might be less expensive than another but unacceptable because distinctly less fair. Other suggested values that might be omitted from an economic analysis are dignity and participation. ${ }^{34}$

This is not a compelling criticism of the economic analysis of procedure. Economic analysis might be capable of treating fairness or participation as benefits to be set off against the costs of providing a fair and inclusive procedure.

But it may be that the economic approach is unable to assign appropriate value to 'rectitude of decision'. In an economic analysis, an incorrect result in a particular matter is bad because it fails to give effect to the goals of the substantive law. An incorrect denial of liability in a personal injury case, for example, may inefficiently allocate loss to the person injured; it may reduce the incentive for others to adopt the efficient, accident-avoiding behaviour required by the substantive law; it fails to deter others from acting in ways that are unlawful (and therefore inefficient). In these ways, incorrect adjudication causes social costs, all of which can be incorporated into a cost/benefit analysis. Yet something seems to be missing from the equation. One would expect that a person who has been wrongly deprived of their legal rights by a court might experience feelings of anger, disappointment or frustration. The economic approach might simply add these negative emotions to

33 See generally Posner, Economic Analysis of Law (2007), above n 26, Chapter 21.

$34 \quad$ Michael Bayles, 'Principles For Legal Procedure' (1986) 5 Law and Philosophy 33, 44. The theme of values that do not relate directly to outcomes is covered in more depth below in the section on 'process values'. 
the 'error costs' side of the equation. ${ }^{35}$ But even an observer with no vested interest in proceedings might feel that something has gone wrong when a court makes the wrong decision. Do these feelings reflect the fact that another kind of damage has been done? Is this, perhaps, damage to the integrity of the justice system rather than just to the parties? Does a denial of legal rights cause some kind of harm that is not incorporated into a conventional economic analysis? Or can 'injustice' simply be added to the 'cost' side of the ledger?

Some economic commentators, such as Kaplow, would argue that the economic approach can readily cope with these concerns simply by assigning a higher value to accuracy. ${ }^{36}$ This makes justice between the parties one of a number of objectives to be weighed in decisions about procedure. It denies that justice has any transcendental quality setting it apart from efficiency objectives. To say that this position is intuitively unattractive is, perhaps, to engage in exactly the sort of 'visceral' argument that the economic approach sets out to avoid. But it is hard to deny the appeal of the notion that, in the context of courts determining legal rights and obligations, there is something special about justice. If justice does have some kind of privileged status, this may mean that it cannot be weighed against competing objectives in the manner required by economic (or other utilitarian) theories. Dworkin's approach, which is outlined in the following section, responds to concerns of this kind.

\section{DWORKIN: A RIGHTS-BASED APPROACH}

The challenge arising from the discussion of economic theories is to develop an approach that attributes special value to justice, while at the same time taking into account concerns about efficiency. Responding to this challenge, ${ }^{37}$ Dworkin develops a theory of procedure hinging on the notion that a special type of harm occurs when a court makes an incorrect decision and thereby fails to enforce a legal right. He describes this harm as the 'injustice factor' or 'moral harm'. ${ }^{38}$ He uses the concept of 'moral harm' to argue that litigants are entitled to a certain level of procedure, no matter how inefficient that may be.

\footnotetext{
35 Kaplow argues that economic analysis consistently incorporates 'the cost of sanctions borne by innocent individuals': Louis Kaplow, 'The Value of Accuracy in Adjudication: An Economic Analysis' (1994) 23 Journal of Legal Studies 307, 387.

$36 \quad$ Ibid 388.

37 Dworkin, above n 1, ch 3. Much of this chapter deals with criminal procedure, but the majority of the analysis is applicable to civil cases: see 92-4. Ibid 80 .
} 
Dworkin begins by identifying two opposite attitudes that a society might adopt towards procedure. On the one hand is the 'justice at any cost' position, which places the aim of achieving the highest possible degree of accuracy in adjudication above all other social objectives. ${ }^{39}$ Few people would support this extreme position, which would require governments to withhold funding from other legitimate social needs whenever money was capable of producing a marginal gain in accuracy in litigation. ${ }^{40}$ On the other hand is a utilitarian position which is broadly similar to the economic approach: procedural law should depend

entirely on the basis of cost-benefit calculations about the best interests of society as a whole, balancing the interests of the [parties] against the interests of those who would gain from public savings in a greatest-good-of-the-greatest-number way. ${ }^{41}$

The first position asserts that litigants have a right to the most accurate procedure possible; the second denies that litigants have a right to any particular procedure or degree of accuracy at all. Dworkin sets out to find the middle ground between these two extreme positions.

He finds this middle ground by reference to the notion of 'moral harm', 42 a concept that he claims 'will escape the net' of any standard utilitarian calculation. ${ }^{43}$ The moral harm theory does not require governments to provide the most accurate procedures possible. But it does recognise that litigants have certain procedural rights. In this way, it departs from the approach advocated by economic scholars: procedural rights act as a 'trump' over competing considerations of efficiency. ${ }^{4}$

Dworkin derives two procedural rights from the notion of moral harm. The first is 'a right to procedures justified by the correct assignment of importance to the moral harm the procedures risk'. ${ }^{45}$ This is 'a background right and a legislative right': 46 it requires the legislature (or the courts in their rule-making capacity) to 'fix civil procedures that correctly assess the risk and importance of moral harm' ${ }^{\prime 47}$ The second right, which is of greater interest for the purposes of this thesis, applies when
Ibid 84 .
Ibid.
Ibid 73.
Ibid ch 3.
Ibid 81 .
Ibid 89 .
Ibid 92.
Ibid 93
Ibid. 
judges make procedural decisions. ${ }^{48}$ This is the 'right to a consistent evaluation of [moral] harm in the procedures afforded [parties to a particular case] as compared with the procedures afforded others in different cases. ${ }^{\prime 4}$ This right does not guarantee litigants any specific procedures, ${ }^{50}$ or even any particular level of accuracy. ${ }^{51}$ But it does entitle them to 'procedures consistent with the community's own evaluation of moral harm embedded in the law as a whole'. ${ }^{52}$ Determining the content of this second right involves establishing 'a textual and historical record' of the procedural laws of a particular society, and interpreting this record in order to determine that society's theory of moral harm. ${ }^{53}$ The second right entitles litigants to treatment that is consistent with the value society has placed on moral harm, as revealed in the textual and historical record. This right will enable a litigant to argue they are entitled to a particular procedure, even when this would be inefficient, because the procedure is necessary in order to give proper weight to the risk of moral harm to that litigant.

Some aspects of Dworkin's theory have been criticised. Does it follow, from the existence of moral harm, that litigants must possess the two procedural rights Dworkin describes? A public, as opposed to party-centred, view of justice may even justify less accurate, more efficient procedures. If the time of courts is disproportionately occupied by a small number of cases, each of which receives extremely thorough (and therefore accurate) procedure, this may mean that many other claims are kept out of court or are not adjudicated until it is too late. If it is impracticable for many breaches of legal rights to be brought before the courts, those wrongs may never be redressed and great moral harm may be incurred: '[w]ithout remedies there are no rights' ${ }^{54}$ If we are serious about upholding legal rights, it may be better to employ more efficient, less accurate procedure to achieve greater access to justice.

In fact, as explained earlier, Dworkin does not suggest that litigants are entitled to the most accurate procedure possible. He acknowledges at the outset that nobody expects governments to pay for such procedure, regardless of cost. ${ }^{55}$ The moral harm theory represents a compromise between absolute accuracy and pure

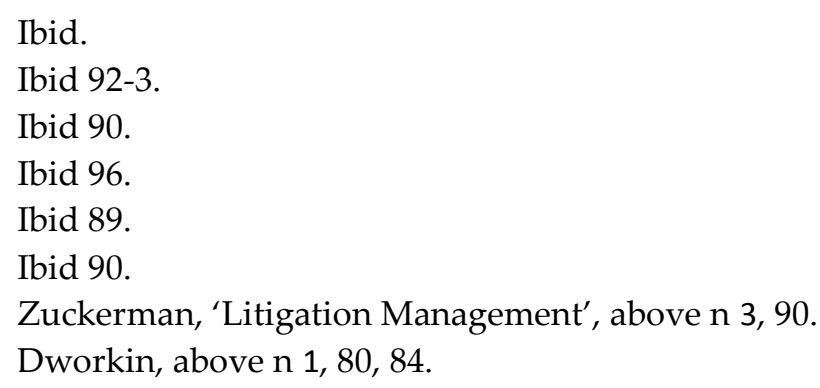


efficiency. Litigants are only entitled to a level of accuracy that is consistent with the value society places on avoiding moral harm. It has been suggested that by using as a reference point the cost that society is willing to pay to avoid moral harm, Dworkin's theory itself approaches utilitarianism. ${ }^{56}$

With this in mind, cannot moral harm be incorporated into a utilitarian balancing exercise? ${ }^{57}$ Dworkin argues that moral harm cannot be caught by utilitarian analysis because it exists objectively, irrespective of whether the harm is perceived by the person who 'suffers' it, or indeed by anybody else. Therefore, he says,

[t]he injustice factor in a mistaken punishment will escape the net of any utilitarian calculation, however sophisticated, that measures harm by some psychological state along the pleasure-pain axis, or by the frustration of desires or preferences or as some function over the cardinal or ordinal preference rankings of particular people, even if the calculus includes the preferences that people have that neither they nor others be punished unjustly. For moral harm is an objective notion, and if someone is morally harmed (or, in the alternative language, if there is a moral loss in the situation) when he is punished though innocent, then this moral harm occurs even when no one knows or suspects it, and even when - perhaps especially when - very few people very much care. ${ }^{58}$

But this reason for placing moral harm beyond the reach of all utilitarian calculations is questionable. Moral harm may be difficult to detect and quantify, but so are many of the other factors that the economic analysis takes into account. ${ }^{59}$ Bayles asserts that, on Dworkin's own account of moral harm, 'one cannot plausibly maintain that no monetary value can be placed on moral costs'. ${ }^{60}$ The appropriate level of protection for moral harm in a particular case depends on the degree to which moral harm is respected in the general law. The relevant content of the general law in turn depends (at least in part) on a series of policy choices about how much society should pay in order to guard against the risk of moral harm. ${ }^{61}$

Despite these difficulties, for the purposes of this thesis Dworkin's theory offers a plausible alternative to Posner's cost-benefit analysis or Zuckerman's balancing exercise. The practical outcome of Dworkin's analysis is that litigants have a right to a minimum standard of procedure. No utilitarian argument can justify a drop below

\footnotetext{
56 Robert G Bone, 'Rethinking the “Day in Court” Ideal and Nonparty Preclusion' (1992) 67 New York University Law Review 255, 262; Bayles, 'Principles For Legal Procedure', above n 34, 48-9.

$57 \quad$ See Kaplow, above n 35, 388.

58 Dworkin, above n 1, 81.

59 Such as, for example, the likely effect of a law on the behaviour of individuals.

60 Bayles, 'Principles For Legal Procedure', above n 34, 48.

61 See Dworkin, above n 1, 87, 95-6.
} 
this standard. In this way, moral harm may mark out the boundaries beyond which procedural law should not stray in the name of efficiency. Within those boundaries, moral harm does not dictate the content of procedural rules; nor does it provide an answer to individual procedural problems. Commenting on Dworkin's work, Zuckerman observes:

We may agree ... that in devising a system of civil procedure, the legislature should take reasonable steps to prevent the injustice that ensues from erroneous decisions, which deny litigants their due. Yet, since the legislature need not strive to take all possible steps to ensure that judgments are factually and legally correct, this leaves a very considerable scope for choice between ... different procedures and for decisions about the allocation of resources to procedure. ${ }^{62}$

Even if we accept Dworkin's theory in its entirety, then, it may amount to no more than a last line of defence against efficiency measures that encroach on the accuracy of judicial determinations. For a judge faced with a procedural decision in which the values of efficiency and justice conflict, Dworkin's theory might rule out some of the more extreme efficiency-based outcomes. But it leaves a substantial margin for judicial choice.

\section{SUMMERS: PROCESS VALUES}

The theories discussed so far in this chapter assess procedure in instrumental ${ }^{63}$ or consequentialist terms. For Zuckerman and Posner, procedure is good if it results in the optimal mix of accurate outcomes and efficient use of party and state resources. For Dworkin, procedure is good if it protects against moral harm; in other words, good procedure leads to accurate outcomes. A fourth influential perspective provides a different way of evaluating procedure: by reference to the values it embodies, rather than the outcomes it produces.

Writing in 1974, Robert S Summers distinguished between 'good result efficacy' and 'process value efficacy'. ${ }^{64}$ A procedure which produces accurate, or cheap, or quick, outcomes has 'good result efficacy'. But for Summers, procedure can be good, irrespective of the results it produces, if it has 'process value efficacy'; that is, if it gives effect to certain values to which the law attaches significance in the area of procedure. He develops the following provisional list of 'process values':

62 Zuckerman, 'Quality and Economy', above n 5, 355.

63 Bayles, 'Principles For Legal Procedure', above n 34, 48-50.

64 Robert S Summers, 'Evaluating and Improving Legal Processes - A Plea for "Process Values"' (1974) 60 Cornell Law Review 1, 4. See also Michael D Bayles, Procedural Justice (Kluwers Academic Publishers, 1990) 127-35. 
participatory governance, ${ }^{65}$ process legitimacy, ${ }^{66}$ peacefulness, ${ }^{67}$ respect for individual dignity, ${ }^{68}$ privacy, ${ }^{69}$ consensualism, ${ }^{70}$ procedural fairness, ${ }^{71}$ procedural legality, ${ }^{72}$ rationality ${ }^{73}$ and 'timeliness and finality' ${ }^{74}$ So, for example, the fact that legal rights are determined by judges rather than by combat or duel can be explained in terms of both 'good result efficacy' (the judge is more likely to reach the legally correct result) and 'process value efficacy' (avoiding a violent duel promotes the process value of peacefulness)..$^{75}$

Unlike the other scholars discussed in this chapter, Summers does not seek to explain the relationship between justice and efficiency in procedure. Rather, he argues that it is not sufficient to consider only outcome-based objectives. Process values are an additional consideration to be taken into account when making procedural decisions.

Is Summers' 'plea for process values' convincing? There are two principal challenges to the theory, both of which challenge the idea that process values have an independent existence. First, on close examination, many 'process values' may have instrumental justifications: ${ }^{76}$ they may be important because they achieve desirable ends, rather than being ends in themselves. The real value of a rational decision-making process, or a fair hearing, or an impartial decision-maker, might be their contribution to a more accurate outcome. A complaint that 'process values' such as participation or fairness have been denied might really be a complaint that the outcome was inaccurate, or simply adverse to the complainant. For example, in relation to the 'process value' of 'participation', Kaplow points out that

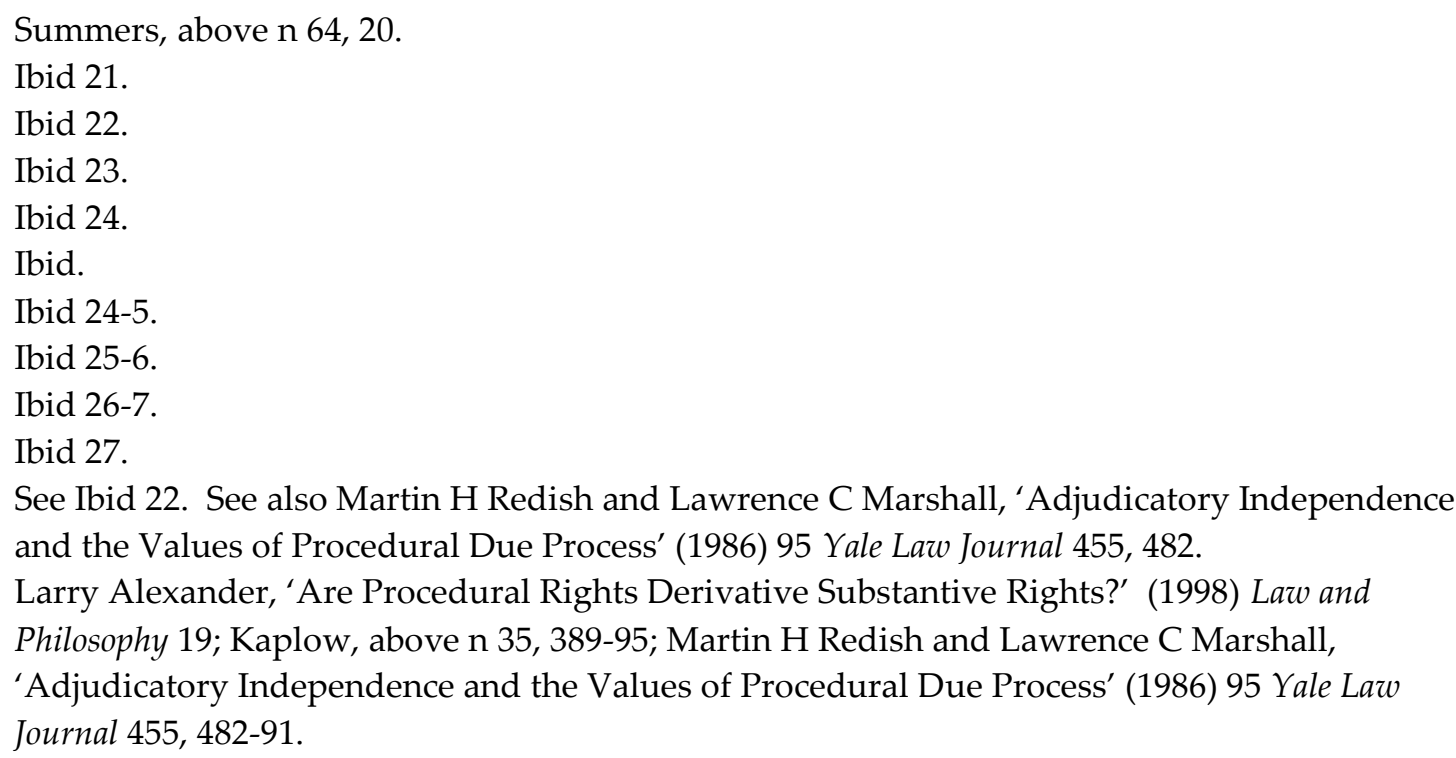


[o]ne does not often hear stories of individuals who win complaining that they did not get their day in court. If there is an independent process value, they would have a claim for reconsideration under proper procedures despite their victory, and if they valued the process significantly, they would choose such a reconsideration, even at some risk of losing. ${ }^{77}$

It is implausible that a successful litigant would take such a step. On the other hand, if 'only losers complain', 'one should be suspicious that the complaint is motivated by a concern for the result, and thus an objection to a lack of process may implicitly be an instrumental argument.' ${ }^{\prime 8}$ On this view, many 'process values' are captured satisfactorily by the value placed by the economic analysis of procedure on accuracy of result, and Summers' work adds little to that analysis. ${ }^{79}$

The second challenge to the existence of 'process values' is that some values, such as 'peacefulness' and respect for individual dignity, are not free-standing process values; rather, they are substantive principles of law that impact upon procedural rules. ${ }^{80}$ So, for example, Summers says that rules prohibiting torture in the investigation of crime serve an instrumental purpose (because evidence obtained under torture is unreliable) but also serve the 'process value' of 'humaneness and respect for individual dignity'. ${ }^{81}$ Even if torture happened to produce reliable evidence and thus contributed to accurate outcomes, it would still be objectionable because it offends process values. ${ }^{82}$ But this is a rather odd way of accounting for rules against 'tortured evidence'. It seems more convincing to say that the substantive law prohibits torture, and this prohibition affects rules of evidence and criminal investigation. In other words, the rules of procedure 'are themselves constrained by ... substantive values' deriving from the substantive law, and not from any separate morality peculiar to the area of procedure. ${ }^{83}$

A defence of process values tends to begin with an appeal to a general intuition 'that process matters to us irrespective of result.' ${ }^{84}$ As Jerry Mashaw argues:

there seems to be something to the intuition that process itself matters. We do distinguish between losing and being treated unfairly. And, however fuzzy our

Kaplow, above n 35, 390 (n 249).

Ibid 390.

Ibid 390, 400.

Alexander, above n 76; Redish and Marshall, above n 76, 484-5.

Summers, above n 64, 23.

Ibid.

Alexander, above n 76, 35.

Jerry L Mashaw, 'Administrative Due Process: The Quest for a Dignitary Theory' (1981) 61

Boston University Law Review 885, 887. 
articulation of the process characteristics that yield a sense of unfairness, it is commonplace for us to describe process affronts as somehow related to disrespect for our individuality, to our not being taken seriously as persons. ${ }^{85}$

There is some empirical support for this intuition. Several studies on litigant behaviour suggest that litigants place importance on qualities such as fairness, impartiality and participation in the court process; and that there is little correlation between the outcome of a case and litigant satisfaction with the court process. ${ }^{86}$

Many existing rules of procedure seem to embody something akin to process values. The rules of natural justice are sometimes justified by reference to values such as institutional legitimacy and respect for individual dignity, as well as on the instrumental ground that the rules improve the accuracy of decision-making. ${ }^{87}$ Similarly, the principle that court proceedings must be held in public has both an 'instrumental' justification - public proceedings are less likely to produce corrupt or irrational results - and a 'non-instrumental' justification - public proceedings enhance the legitimacy of the court process. ${ }^{88}$ These rules of procedure have an importance that goes beyond their contribution to achieving justice in a particular case. To the legal system, as well as to individual litigants, process matters.

The importance of process values might be explained by reference to John Rawls' concept of 'procedural justice'. 'Perfect procedural justice' exists when 'there is an independent standard for deciding which outcome is just and a procedure guaranteed to lead to it.' 89 While court procedure may aim to produce a just outcome, it cannot guarantee to do so. Court procedure is better understood as producing either 'imperfect' or 'pure' procedural justice. 'Imperfect procedural justice' exists when 'there is an independent criterion for the correct outcome' but

85 Ibid 888 (emphasis in original, citations omitted).

86 See, eg, John Thibaut and Laurens Walker, Procedural Justice (Hillsdale, 1975); Laurens Walker, E Allan Lind and John Thibaut, 'The Relation Between Procedural and Distributive Justice' (1979) 65 Virginia Law Review 1401; Tom R Tyler, 'Procedural Justice and the Courts' (2007) 44 Court Review 26; Tania Matruglio, Plaintiffs and the Process of Litigation: An Analysis of the Perceptions of Plaintiffs following their Experience of Litigation (Law Foundation of NSW, Sydney, 1994); Marketshare Pty Ltd, Community and Client Perceptions of the Queensland Court System (1991) cited in BC Cairns, 'Lord Woolf's Report on Access to Justice: An Australian Perspective' (1997) 16 Civil Justice Quarterly 98, 101; E Allan Lind et al, 'In the Eye of the Beholder: Tort Litigants' Evaluations of Their Experiences in the Civil Justice System' (1990) 24 Law and Society Review 953.

87 See, eg, Mark Aronson, Bruce Dyer and Matthew Groves, Judicial Review of Administrative Action (Thomson Reuters, $4^{\text {th }}$ ed, 2009), 404-8.

$88 \quad$ See Russell v Russell (1976) 134 CLR 495, 520 (Gibbs J).

89 John Rawls, A Theory of Justice (Bellknap Press of Harvard University Press, 1971) 85. 
'there is no feasible procedure which is sure to lead to it'..$^{90}$ Rawls posits the criminal trial as an example of imperfect procedural justice. ${ }^{91}$ It is possible to design procedures that will produce the right outcome (convicting the guilty and not the innocent) in most cases, and if the wrong outcome is reached, this will spring 'from no human fault but from a fortuitous combination of circumstances which defeats the purpose of the ... rules.' ${ }^{92}$ 'Pure procedural justice', on the other hand, exists where

there is no independent criterion for the right result: instead there is a correct or fair procedure such that the outcome is likewise correct or fair, whatever it is, provided that the procedure has been properly followed. ${ }^{93}$

If one accepts that there is an objectively correct result in every legal dispute, with the court's task being to reach that outcome, then trials present a situation of imperfect procedural justice. If, however, one believes that many legal questions do not have a single 'right' answer, then a trial becomes a situation in which pure procedural justice is relevant. We cannot say whether a judge has reached the correct outcome, but we can assess whether she has followed fair procedures. As Zuckerman has argued:

we do not have a super-test for judging the conformity of judgments to the truth. All we possess is the legal procedure that we have devised. It follows that our confidence in the justice of any given decision, in its conformity with fact and law, is a function of our confidence in the procedure that has produced the particular result, or of our acceptance of the procedure, as distinguished from the particular result, as a just procedure. ${ }^{94}$

In other words, because it is so difficult to know whether court procedure has produced a just result, we judge procedure by its inherent values, not only by the results it produces.

Accepting, then, that process values exist and are important, what role ought they to play in formulating and applying rules of civil procedure? Can process values be translated into process rights? Might litigants might have a positive right to procedures that reflect certain process values such as procedural fairness or participation? One view is that, while it might be nice to hold values such as dignity and participation, it hardly seems worth investing resources in their promotion

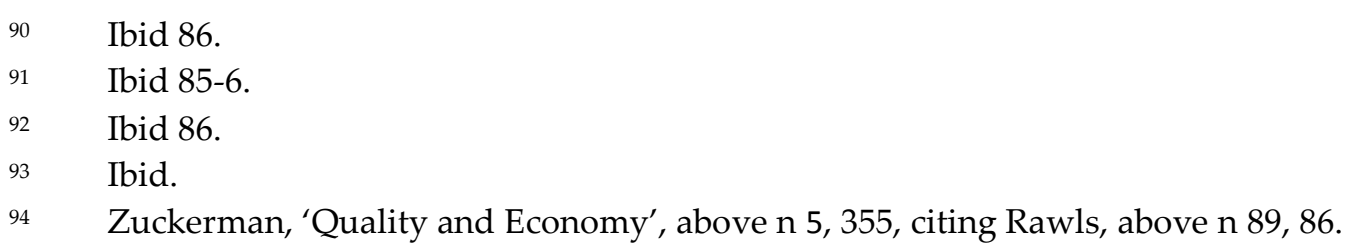


through the medium of procedure. ${ }^{95}$ Summers himself makes a relatively modest claim - that '[p]rocess values are relevant in evaluating and in choosing between legal processes, actual or proposed. ${ }^{\prime 96}$ He accepts that process values can sometimes be sacrificed in order to achieve desired results. ${ }^{97}$ Process values, then, are a factor which can contribute to, but not necessarily dictate, procedural decisions.

\section{CONCLUSION}

The discussion in this chapter demonstrates that there are a number of distinct ideas about the way in which the goals of efficiency and justice ought to be implemented in procedural law. For Zuckerman and Posner, considerations of efficiency and justice must be weighed against each other, and a compromise reached that brings about the greatest overall good. These approaches treat the goal of giving effect to substantive legal rights as one of several objectives of procedure, which can be compromised in order to achieve other goals. For Dworkin, in contrast, litigants have non-negotiable procedural rights that cannot be sacrificed in the name of efficiency. Summers offers a different perspective. Procedure can do more than produce just and efficient outcomes; it can embody values such as dignity and participation. On this view, procedure should aim to incorporate these values even if this is not conducive to either efficiency or justice.

How are these theories relevant to this thesis? I will use the theories throughout this thesis to comment on aspects of procedural law in practice. The theories reinforce a point made in Chapter 2 of this thesis: procedure has multiple goals. Procedure is not just about achieving a legally correct outcome between the parties; it can also be used to achieve efficiency for the parties and for the public, and to give effect to process values. But the theories provide only a partial answer to the question of how to reconcile these different aims of procedure. Posner's economic theory has the potential to offer concrete solutions to procedural dilemmas, but arguably at the cost of failing to place appropriate value on the objective of doing justice between the parties. Summers' process values do not pretend to constitute a complete answer to the question; they are an additional consideration to be taken into account. Zuckerman's idea of finding the right mix between the three dimensions of justice begs the question of how to determine how much weight to place on each dimension in a given case. Dworkin's 'moral harm' thesis promises to set a minimum level of procedure that cannot be compromised for efficiency reasons, but offers little

\footnotetext{
95 See, eg, Alexander, above n 76, 36.

96 Summers, above n 64, 38.

97 Ibid 39.
} 
guidance on how to choose between alternatives that sit above that minimum level. If a judge, faced with a procedural decision in which the objectives of efficiency and justice conflict, were to look to these theories for guidance, they would find themselves left with a substantial margin of discretion.

Having considered these theoretical perspectives, we will now see how the relationship between justice and efficiency in civil procedure has played out in practice. In Chapters 6 and 7 I examine the history of civil procedure in Australia. This will demonstrate a fundamental shift in our understanding of the function of courts and the aims of civil procedure. A party-centred view of justice is consistent with long accepted ideas about the role of the court, and has been influential in the development of civil procedure in Australia. The public view of justice, on the other hand, has become far more prominent in the last two to three decades. 


\section{Chapter 6: A Brief History of Justice ANd EfFiciency in Civil Procedure}

\section{INTRODUCTION}

Dissatisfaction with the administration of justice is as old as law. ${ }^{1}$

In the previous chapter we saw that the relationship between justice and efficiency in procedure has presented scholars with challenging, and largely unresolved, questions. Of course, these are not solely theoretical questions. On the contrary, the question of how to give effect to the different goals of civil procedure is one with which courts wrestle daily. The next two chapters explore the ways in which this challenge has been approached over the last 150 years of Anglo-Australian civil procedure.

These chapters are important to the thesis for two reasons. First, they provide some further perspectives on the puzzle at the centre of the thesis: the relationship between justice and efficiency in civil procedure. Secondly, they provide context for the discussion, in Part III of this thesis, of how judges deal with mega-litigation. Mega-litigation does not exist in a vacuum; decisions about how to manage megalitigation are informed by the principles and rules of civil procedure generally.

This chapter takes the form of a brief history of civil procedure from the mid-19th century to the early 1990s. Over the last 150 years, the law of civil procedure has progressed through a series of evolutionary stages. ${ }^{2}$ Each evolutionary change was precipitated by the need to overcome problems with the existing system, and to meet society's changing demands. Section II of the chapter explains the concerns that led to one of the most momentous events in the history of civil procedure: the passing of the UK Judicature Acts in the 1870s. The Judicature Acts removed much of the excessive complexity of procedure, ushering in a new era in which the dominant aim of procedure was justice between the parties to each case. This era is the subject of section III of this chapter. Giving litigants free rein to run their cases led to undesired levels of expense and delay in litigation. This, in combination with increasing caseloads and changing community expectations, led to the next stage in the evolution of civil procedure: the rise of case management, discussed in section IV of this chapter. This overview of the evolution of civil procedure sets the stage for a

Roscoe Pound, 'The Causes of Popular Dissatisfaction With the Administration of Justice' (1906) 40 American Law Review 729, 729.

2 The experience in the United States has been quite similar. Robert G Bone describes American procedure as passing through three eras between the 1840s and the present, each area roughly corresponding to those described here: Robert G Bone, 'Making Effective Rules: The Need for Procedure Theory' (2008) 61 Oklahoma Law Review 319, 320-7. 
more detailed examination, in Chapter 7, of developments in Australian civil procedure over the last two decades.

The current chapter identifies some legislative and judicial landmarks in the history of procedural law, as well as providing an overview of the way in which civil procedure has worked in practice, and of the development of different perspectives on procedure. My aim is to provide an account of the major influences on Australian civil procedure. Many of these influences, however, come from other jurisdictions. English procedure provided the blueprint for Australian procedure, while the managerial approach discussed in section IV is an American invention. Where appropriate, this chapter draws on material from those other jurisdictions. A natural starting point for discussion of modern procedure is the English civil justice system of the mid-1800s; a system that has been described as 'very little system and precious little justice'. ${ }^{3}$

\section{THE JUDICATURE ACTS}

Nineteenth-century English procedure was notorious for its extraordinary complexity and formality. ${ }^{4}$ Quite apart from the huge time and cost of litigation, claims were as likely to fail on procedural grounds as on their merits. ${ }^{5}$ The 'outstanding feature' 6 of the administration of justice at this time was the division of the courts of law and equity. Lord Bowen, writing in 1887, explained the problems this created for litigants:

Suits in Chancery were lost if it turned out at the hearing that the plaintiff, instead of filing his bill in equity, might have had redress in a law court; just as plaintiffs were nonsuited at law because they should have rather sued in equity, or because some partnership or trust appeared unexpectedly on the evidence when all was ripe for judgment. Thus the bewildered litigant was driven backwards and forwards from law to equity, from equity to law. ${ }^{7}$

3 Sir Jack IH Jacob, 'Civil Procedure Since 1800' in The Reform of Civil Procedural Law (Sweet \& Maxwell, 1982) 193, 194.

4 Ibid 194-204; Lord Bowen, 'Progress in the Administration of Justice During the Victorian Period', in Select Essays in Anglo-American Legal History, Volume 1 (Little, Brown and Company, 1908) 516; Federal Court of Australia, Case Management Handbook (13 October 2011), 9 [2.8]. For a more colourful treatment of the problems associated with civil procedure in this era, see Charles Dickens, Bleak House (1853).

$5 \quad$ See Adrian Zuckerman, Zuckerman on Civil Procedure: Principles of Practice (Sweet \& Maxwell, $2^{\text {nd }}$ ed, 2006) 25-7; WB Odgers, 'Changes in Procedure and in the Law of Evidence' in A Century of Law Reform (Macmillan \& Co, 1901) 203.

Jacob, 'Civil Procedure Since 1800', above n 3, 195.

Bowen, 'Progress in the Administration of Justice During the Victorian Period', above n 4, 516, 518. 
Even if a litigant managed to commence their case in the correct jurisdiction, their problems were not over. Common law procedure was 'antiquated, technical and obscure' ${ }^{8}$ Sir Jack Jacob described some of its features:

Their procedure was based upon the system of special pleading, which, however admissible as a species of dialectic, inevitably promoted excessive technicality and absorption in mere forms. Just claims were liable to be defeated by trivial errors in pleading, by infinitesimal variances between pleading and proof and by the non-joinder or misjoinder of mere nominal parties. The arbitrary classification of actions into 'forms of action' was another pitfall into which the most wary sometimes fell. If a surprise occurred at nisi prius, the court was unable to adjourn the proceedings a single day. And, as a crowning paradox, a fundamental rule of evidence excluded absolutely the testimony of the parties and of all witnesses who had the remotest interest in the result. ${ }^{9}$

Procedure in the Court of Chancery was no better; it was 'more technical, if that were possible, than the courts of common law themselves'. ${ }^{10}$ Moreover, Chancery was famously dilatory. A litigant could not commence a suit in equity 'with any reasonable hope of being alive at its termination, if he ha[d] a determined adversary'. ${ }^{11}$

It was in response to these widely recognised problems that the 1873 and 1875 Judicature Acts ${ }^{12}$ were passed. The Judicature Acts fused the jurisdictions of common law and equity, so that an action could no longer be defeated on the basis that it was commenced in the wrong jurisdiction. In addition, the complexity of procedure was greatly reduced. The reforms had their 'teething troubles'13 - the new procedures were still 'far too elaborate and precise' for many cases, and there was an immediate increase in the cost of average proceedings. ${ }^{14}$ Nonetheless, the Judicature Acts were a

8 Bowen, 'Progress in the Administration of Justice During the Victorian Period', above n 4, 516, 519.

$9 \quad$ Jacob, 'Civil Procedure Since 1800', above n 3, 197 (citations omitted).

10 Odgers, above n 5, 207.

11 George Spence, First Address to the Public, and More Especially to the Members of the House of Commons, on the Present Unsatisfactory State of the Court of Chancery; and Suggestions for an Immediate Remedy (W Walker and Ridgways, $2^{\text {nd }}$ ed, 1839), 9.

12 Supreme Court of Judicature Act 1873 (UK); Supreme Court of Judicature Act 1875 (UK).

13 Patrick Polden, 'The Judicature Acts' in The Oxford History of the Laws of England (Oxford University Press, 2010) vol XI, 757, 766-70.

14 Lord Bowen, 'Law Courts Under the Judicature Acts' (1886) 2 Law Quarterly Review 1, 8 (emphasis in original). 
'great stride forward'15 for civil procedure. In the next section, we will examine the way in which civil procedure developed following the passing of the Judicature Acts.

\section{Post-Judicature Acts: Justice BetWeen the PARTies}

In Chapter 2 of this thesis, I argued that civil procedure can have multiple objectives. I classified these aims as justice and efficiency, from the point of view of the parties to a case and from the point of view of the public. Post-Judicature Acts procedure was directed almost exclusively to one of these aims: justice between the parties. ${ }^{16}$ Late 19th- and early 20th-century courts carefully avoided any suggestion that rules, rather than substantive justice, dictated procedure. Collins MR famously described the relationship between procedural and substantive law in the following terms:

The relation of rules of practice to the work of justice is intended to be that of handmaid rather than mistress and the Court ought not to be so far bound and tied by rules, which are after all only intended as general rules of procedure, as to be compelled to do what will cause injustice in the particular case. ${ }^{17}$

In Cropper $v$ Smith $^{18}$ Bowen LJ made a similarly emphatic statement of the primacy of justice between the parties. In relation to a proposed amendment of pleadings, his Honour said:

the object of Courts is to decide the rights of the parties, and not to punish them for mistakes they make in the conduct of their cases by deciding otherwise than in accordance with the rights. ... I know of no kind of error or mistake which, if not fraudulent or intended to overreach, the Court ought not to correct, if it can be done without injustice to the other party. Courts do not exist for the sake of discipline, but for the sake of deciding matters in controversy, and I do not regard such amendment as a matter of favour or grace. ... It seems to me that as soon as it appears that the way in which a party has framed his case will not lead to a decision of the real matter in controversy, it is as much a matter of right on his part to have it corrected, if it can be done without injustice, as anything in case is a matter of right. ${ }^{19}$

15 Jacob, 'Civil Procedure Since 1800', above n 3, 205.

16 See Adrian Zuckerman, 'Litigation Management Under the CPR: A Poorly-Used Management Infrastructure' in Deirdre Dwyer (ed), The Civil Procedure Rules Ten Years On (Oxford University Press 2009) 89, 98; Zuckerman, Zuckerman on Civil Procedure, above n 5, 27; John Sorabji, ‘Late Amendment and Jackson's Commitment to Woolf: Another Attempt to Implement a New Approach to Civil Justice' (2012) 31 Civil Justice Quarterly 393, 395-9.

$17 \quad$ Re Coles and Ravenshear [1907] 1 KB 1, 4.

$18 \quad$ (1884) 26 Ch D 700.

19 Cropper $v$ Smith (1884) 26 Ch D 700, 710-1. Another frequently cited example of the traditional approach appears in Clarapede \& Co $v$ Commercial Unions Association (1883) 32 WR 262, 263 (Brett MR): ('However negligent or careless may have been the first omission, and however late the 
Although Bowen LJ was in dissent in this case, his view became as a 'classical statement $^{\prime 20}$ on the role of the court in procedural matters. This approach was approved in Australia by the High Court, ${ }^{21}$ and was regularly applied by intermediate courts. In an early High Court case on the amendment of pleadings, Isaacs J said that

There is not only a power, but even an imperative duty cast by the legislature on the Court, to let no formality stand in the way of solid justice. The Court is directed to make every amendment, and at all times, so as to enable it to do what is right between the parties, and in the fairest and fullest manner possible to arrive at a determination of the substantial matter in dispute. ${ }^{22}$

Much later, in 1974, the High Court reaffirmed Bowen LJ's approach. In Clough and Rogers $v$ Frog, ${ }^{23}$ McTiernan ACJ, Menzies, Gibbs and Mason JJ explained that a primary judge had erred in refusing to allow a defendant to amend their pleadings so as to raise a new defence:

As the defence, if established, would be a complete answer ..., the amendments sought should have been allowed unless it appeared that injustice would thereby have been occasioned to the respondent ... [T] [Te matters relied upon by the respondent in opposition to the amendment sought go at the most to delay and irregularity only, matters which are relevant to costs but do not constitute injustice to the respondent in the sense in which that expression is used. ${ }^{24}$

These quotes demonstrate the prevailing view, post-Judicature Acts, that the role of civil procedure was to enable the court to determine disputes on their merits, in a way that was fair to the parties. This appears to have been a reaction to the excessive technicality and injustices of the pre-Judicature Acts era. Now, there was a narrow focus on doing justice between the parties, with little concession to efficiency considerations. Litigants were seen as having a positive right to ventilate the issues in dispute, and there was a corresponding duty on the court to determine those

proposed amendment, the amendment should be allowed if it can be made without injustice to the other side.') See also Tildesley v Harper (1878) LR 10 Ch D 393, 396-7 (Bramwell LJ) ('My practice has always been to give leave to amend unless I have been satisfied that the party applying was acting malâ fide, or that, by his blunder, he had done some injury to his opponent which could not be compensated for by costs or otherwise.')

20 Queensland v JL Holdings Ltd (1997) 189 CLR 146, 164 (Kirby J).

$21 \quad$ Shannon v Lee Chun (1912) 15 CLR 257, 261-2; Clough and Rogers v Frog (1974) 48 ALJR 481, 482.

22 Shannon $v$ Lee Chun (1912) 15 CLR 257, 265. Both Cropper $v$ Smith and Shannon $v$ Lee Chun involved application of a rule providing that 'All such amendments shall be made as may be necessary for the purpose of determining the real question in controversy between the parties.' (1974) 48 ALJR 481.

Ibid 482. 
issues on their merits. The one apparent limit on the freedom of the parties to take virtually any procedural step they saw fit was that injustice must not be done to another party in the case. Even so, virtually all prejudice caused to other parties could easily be cured by what Bowen LJ described as the 'panacea which heals every sore in litigation': an order for costs. ${ }^{25}$

It would be too simplistic to say that efficiency considerations played no role in procedural law during this era. The principle of res judicata, for instance, prioritised the 'public interest' in bringing litigation to an end ahead of the objective of determining the rights of the parties. ${ }^{26}$ Limitation periods and rules providing for summary or default judgment allowed the possibility that actions could be disposed of without a full hearing on the merits, albeit subject to strict limits and discretionary considerations. Overall, however, the principles of civil procedure and the way in which the rules were applied gave primacy to the objective of doing justice between the parties.

A further, related, principle emerged as a feature of post-Judicature Acts procedure: the parties controlled the litigation process. Not only did litigants have a right to have the real issues determined; they also had the right to choose how and when this happened. The respective roles of the parties and the court were defining features of the adversary system. Sir Jack Jacob explained that:

The major premise of the adversary system is that it is the overriding duty of a court of law to remain at all times passive, neutral and inactive, so that the adversaries, or as they are sometimes called, the legal gladiators, should conduct their own litigation in their own way, subject to the rules and practices of the court. The court should never descend into the arena and should never wear or appear to wear the mantle of the advocate. The role of the court is seen, and indeed it is required that it should be seen, as that of an umpire who will ensure that the parties observe the rules of the game. The court does not, and virtually cannot, take initiative at any stage of the proceedings but must leave that to the parties or their lawyers who, under the principles of what are called party control and party prosecution, are entitled and required to exercise control over the conduct of the proceedings, ... and it is the parties and their lawyers who retain

25 Cropper $v$ Smith (1884) 26 Ch D 700, 711 (Bowen LJ). See also Clarapede \& Co v Commercial Union Association (1883) 32 WR 262, 263.

26 See The Ampthill Peerage [1977] AC 547, 575; Johnson v Gore Wood \& Co [2002] 2 AC 1, 31. For a well-known example of the principle of res judicata bringing about a result which was arguably contrary to the merits of the case, see Chamberlain $v$ Deputy Commissioner of Taxation (1988) 164 CLR 502. 
throughout the initiative of taking whatever steps or measures they consider necessary or desirable in the progress of the proceedings before trial. ${ }^{27}$

This passage reflects the view that party control of proceedings is not merely a matter of convenience; it is a means of preserving judicial impartiality. Party control is, as Jacob points out, a feature that distinguishes 'adversarial' from 'inquisitorial' systems of justice. To similar effect are the remarks of Denning LJ, in his iconic explanation of the role of the judge in an adversarial system:

In the system of trial which we have evolved in this country, the judge sits to hear and determine the issues raised by the parties, not to conduct an investigation or examination on behalf of society at large, as happens, we believe, in some foreign countries. Even in England, however, a judge is not a mere umpire to answer the question 'How's that?' His object, above all, is to find out the truth, and to do justice according to law; and in the daily pursuit of it the advocate plays an honourable and necessary role. Was it not Lord Eldon LC [in Ex Parte Lloyd (1822) Mont 70, 72n] who said in a notable passage that 'truth is best discovered by powerful statements on both sides of the question'? ... And Lord Greene MR who explained that justice is best done by a judge who holds the balance between the contending parties without himself taking part in their disputations?

The judge's part in all this is to hearken to the evidence, only himself asking questions of witnesses when it is necessary to clear up any point that has been overlooked or left obscure; to see that the advocates behave themselves seemly and keep to the rules laid down by law; to exclude irrelevancies and discourage repetition; to make sure by wise intervention that he follows the points that the advocates are making and can assess their worth; and at the end to make up his mind where the truth lies. If he goes beyond this, he drops the mantle of a judge and assumes the robe of an advocate; and the change does not become him well. ${ }^{28}$

For many years, civil procedure was driven by these ideas about the right of parties to control proceedings. It was the parties' prerogative to choose how, and at what pace, the case would progress. ${ }^{29}$ There was little the court could (or should) do to expedite proceedings or to prevent the parties running up huge costs bills. Nor could the court intervene with the purpose of securing public efficiency or even

27 Jacob, 'The Reform of Civil Procedural Law', in Sir Jack IH Jacob, The Reform of Civil Procedural Law (Sweet \& Maxwell, 1982) 1, 24-5 (citations omitted).

Jones $v$ National Coal Board [1957] 2 QB 55, 63-4.

See Sir Jack Jacob, The Fabric of English Civil Justice (1987), 12-13; Sir Anthony Clarke MR, 'The Supercase - Problems and Solutions: Reflections on BCCI and Equitable Life' (KPMG Forensic's Annual Law Lecture 2007, London, 29 March 2007). 
justice from the public point of view. The pursuit of these aims was not the business of the court.

\section{THE Rise OF CASE MANAGEMENT}

In the latter half of the 20th century, it became apparent that the party-controlled, 'justice on the merits' approach to civil procedure had its downside. Left to their own devices, parties (and their lawyers) tended to let litigation proceed at a leisurely pace, and to engage in extensive interlocutory arguments. ${ }^{30}$ Judges steeped in the procedural tradition of Cropper $v$ Smith $^{31}$ were willing to excuse almost any procedural default in order to do justice between the parties. As a result, the cost and time involved in litigation reached levels that made the courts inaccessible - or at least extremely unattractive - to most people. ${ }^{32}$ At the same time, an increase in litigation resulting from population growth, increasingly complex commercial activity and new levels of legislative regulation placed ever greater pressure on courts. Society's attitude to government was also changing, with government expected to take a more active role in addressing social and economic problems. ${ }^{33}$ It was in this context that case management evolved. ${ }^{34}$

The specific mechanisms of case management (sometimes referred to as 'caseflow management') vary between courts and, indeed, between judges and between different types of cases. Typically, though, case management involves a case being assigned to a single judge and called on for regular pre-trial hearings before that judge. ${ }^{35}$ Rather than applying rigid rules of procedure, the case managing judge

30 See, eg, Clarke, above n 29, 6; Master Evan Bell, 'Judicial Case Management' (2009) Judicial Studies Institute Journal 76, 79-80; Justice CW Pincus, 'Court Involvement in Pre-Trial Procedures' (1987) 61 Australian Law Journal 471; Justice Andrew Rogers, ‘The Managerial or Interventionist Judge' (1993) 3 Journal of Judicial Administration 96; Zuckerman, 'Litigation Management Under the CPR', above n 16, 98-9; Maureen Solomon, 'The Rationale for Court Leadership: Insights From the US Experience' in Courts Advisory Council, Victoria, Caseflow Management in Australian Courts (November 1988), 96, 98; Lord Woolf, Access to Justice: Interim Report to the Lord Chancellor on the Civil Justice System in England and Wales (June 1995) 7-8.

$31 \quad$ (1884) 26 Ch D 700. See above at 85.

32 See, eg, AAS Zuckerman, 'A Reform of Civil Procedure - Rationing Procedure Rather than Access to Justice '(1995) 22 Journal of Law and Society 155; Woolf, Interim Report, above n 30, 9-15.

33 See Justice DA Ipp, 'Judicial Intervention in the Trial Process' (1995) 69 Australian Law Journal 365.

34 See Robert F Peckham, 'The Federal Judge as a Case Manager: The New Role in Guiding a Case from Filing to Disposition' (1981) 69 California Law Review 770, 770; Ipp, above n 33, 376-8; Chief Justice James Allsop, 'Judicial Case Management and the Problem of Costs' (Speech at the Lord Dyson lecture on 'The Jackson Reforms to Civil Justice in the UK', Sydney, 9 September 2014), 2-5.

35 For some descriptions of case management, see Federal Court of Australia, above n 4; Judge William W Schwarzer, 'Case Management in the Federal Courts' (1996) 15 Civil Justice Quarterly 
'tailors the procedures to be employed to the individual case.' ${ }^{36}$ At case management hearings, the managing judge is able to make orders about the procedural steps that the parties are to take - such as pleadings, discovery and the gathering of evidence and to set timetables for the completion of these steps. Case management may also extend beyond the pre-trial stages into the conduct of the trial itself, with judges guiding the way in which evidence and argument is presented.

Case management turns on its head the principle of party control. Once litigation is understood as involving considerations of public justice and public efficiency, the principle of party control becomes untenable. It is unrealistic (and probably unreasonable) to expect parties to litigation to modify their litigation behaviour for the good of the public. Andrew Higgins explains:

The absurdity of [party control] becomes obvious when transplanted to the management of other public services: it would be akin to patients deciding when they would have their operations and how long they would stay in hospital; or parents deciding how many hours of tuition their children should receive. Users of public services are not well placed to manage them efficiently or fairly. ${ }^{37}$

If the goals of public justice and public efficiency are to be pursued, responsibility for the conduct of litigation must shift from the parties to a public authority. Under a case management regime, the judge becomes responsible for the progress of litigation. ${ }^{38}$ Instead of being passive and aloof, the case managing judge assumes an active role. ${ }^{39}$ The judge can initiate procedural steps, help define the issues for resolution, and give parties 'feedback' ${ }^{40}$ about their cases. ${ }^{41}$

141; Bell, above n 30, 86-110; Maureen Solomon, Caseflow Management in the Trial Court (American Bar Association Commission on Standards of Judicial Administration, 1973).

36 Michael Legg, Case Management and Complex Civil Litigation (Federation Press, 2011), 5.

37 Andrew Higgins, 'The Costs of Case Management: What Should be Done Post-Jackson?' (2010) 29 Civil Justice Quarterly 317, 324.

38 See Solomon, Caseflow Management in the Trial Court, above n 35, 2-3; Lord Woolf, Access to Justice: Final Report to the Lord Chancellor on the Civil Justice System in England and Wales (1996); Judge William W Schwarzer, 'Case Management in the Federal Courts' (1996) 15 Civil Justice Quarterly 141, 141; Chief Justice JJ Spigelman, 'Citizens, Consumers and Courts' (2001) 60 Australian Journal of Public Administration 5; Justice Ronald Sackville, 'Courts in Transition: An Australian View' (2003) New Zealand Law Review 185, 198; Craig Down, 'Crying Woolf? Reform of the Adversarial System in Australia' (1998) 7 Journal of Judicial Administration 213, 219.

39 See ED Elliott, 'Managerial Judging and the Evolution of Procedure' (1986) 53 University of Chicago Law Review 306; Schwarzer, above n 35, 145; Woolf, Interim Report, above n 30, 18-9, 269; Legg, above n 36, 8.

$40 \quad$ Bell, above n 30, 102.

41 See Federal Court of Australia, above n 4, [3.6] 12. 
The 'case management' movement began in the United States in the 1960s, as a response to increasing caseloads and the consequent backlogs of cases. ${ }^{42}$ Unlike the Judicature Acts, case management was not the result of legislative action. Nor was it the result of a single seminal case. ${ }^{43}$ Case management was a 'judge-driven reform' ${ }^{44}$ It developed court by court, judge by judge and case by case as a pragmatic response to the challenges faced by courts whose growing workloads were not matched by greater resources. ${ }^{45}$ Writing of the American experience, ED Elliott observed:

What makes the managerial judging movement coherent is not so much the existence of specific techniques on which all managerial judges agree. Rather, managerial judges are distinguished by common themes in their rhetoric. Managerial judges believe that the system does not work; that something must be done to make it work; and that the only plausible solution to the problem is ad hoc procedural activism by judges. ${ }^{46}$

In Australia, Gummow $\mathrm{J}$ has described the approach that prevailed in the Federal Court from its inception: 'We did not call it case management. We called it getting on with it.' ${ }^{47}$

Many of the themes underlying the case management movement crystallised in the influential speech of Lord Griffiths in 1987's Ketteman v Hansel Properties Ltd. ${ }^{48}$ Ketteman has been described as

the single event which has led the courts in [Australia] to expressly to take into account the needs of other litigants and the public in carrying out the exercise of the relevant judicial discretion. ${ }^{49}$

42 See Judge Irving R Kaufman, 'Courts in Crisis' (1966) 52 American Bar Association Journal 1026; Judge Ruggero J Aldisert, 'A Metropolitan Court Conquers Its Backlog' (1968) 51 Judicature 202; Joseph D Tydings, 'A Fresh Approach to Judicial Administration' (1966) 50 Judicature 44; Judith Resnik, 'Managerial Judges' (1982) 96 Harvard Law Review 374, 397-9.

43 Although some cases (notably Ketteman v Hansel Properties Ltd [1987] AC 189, discussed below at 91-2), have been influential.

44 Justice GL Davies, 'Civil Justice Reform in Australia' in Adrian AS Zuckerman (Ed), Civil Justice in Crisis (Oxford University Press, 1999) 166, 194.

45 Justice Ronald Sackville, 'The Future of Case Management in Litigation' (2009) 18 Journal of Judicial Administration 211, 213; Sackville, 'Courts in Transition', above n 38, 199-200.

$46 \quad$ Elliott, above $\mathrm{n} 39,309$ (emphasis in original).

47 His Honour added 'You did not get PhDs in the subject either': Transcript of Proceedings, GMCA Pty Ltd v Black \& Decker Inc [2007] HCATrans 662 (14 November 2007), 14. [1987] AC 189, 220.

$49 \quad$ Macquarie Bank Ltd v National Mutual Life Association of Australia Ltd (1996) 40 NSWLR 543, 553 (Clarke JA), referring to GSA Industries Pty Ltd v NT Gas Ltd (1990) 24 NSWLR 710, 716 (Samuels JA); State Pollution Control Commission v Australian Iron \& Steel Pty Ltd (1993) 29 
Ketteman concerned an application to amend pleadings. On the 'justice on the merits' approach to procedure, exemplified by Cropper $v$ Smith, ${ }^{50}$ amendments were allowed as a matter of right, so long as any prejudice to opposing parties could be cured by an order for costs. This was consistent with the idea that procedure should aim to do justice between the parties: if the amendment was necessary to ensure that the real issues were ventilated, it must be allowed. It was also consistent with the principle of party control: it was for the parties to decide how to frame their case, and at what pace to run the litigation. In Ketteman, Lord Griffiths departed from this approach. His Lordship said that, 'whatever may have been the rule of conduct a hundred years ago', ${ }^{51}$ courts were no longer under any obligation to allow late amendments. On the contrary, whether to allow an amendment was a matter for the judge's discretion, to be guided by the judge's 'assessment of where justice lies'. ${ }^{52}$ 'Many and diverse' factors were relevant to this discretion. ${ }^{53}$ One significant factor was the effect of the amendment on the other party to the case. Lord Griffiths rejected the traditional view that an order for costs could cure any prejudice:

[J]ustice cannot always be measured in terms of money and in my view a judge is entitled to weigh in the balance the strain the litigation imposes on litigants, particularly if they are personal litigants rather than business corporations, the anxieties occasioned by facing new issues, the raising of false hopes, and the legitimate expectation that the trial will determine the issues one way or the other. $^{54}$

This passage reflects a more sophisticated understanding of doing justice between the parties. But Lord Griffiths also invoked much broader considerations:

Another factor that a judge must weigh in the balance is the pressure on the courts caused by the great increase in litigation and the consequent necessity that, in the interests of the whole community, legal business should be conducted efficiently. We can no longer afford to show the same indulgence towards the negligent conduct of litigation as was perhaps possible in a more leisured age. ${ }^{55}$

This view introduces public efficiency and public justice as legitimate aims of civil procedure.

NSWLR 487, 494-5 (Gleeson CJ); Byron v Southern Star Group Pty Ltd (1995) 123 FLR 352, 353 (Kirby P); Sali v SPC Ltd (1993) 67 ALJR 841, 843-4.

$50 \quad$ (1884) $26 \mathrm{Ch}$ D 700. See discussion above at 85.

$51 \quad K e t t e m a n v$ Hansel Properties Ltd [1987] AC 189, 220, referring to Clarapede \& Co v Commercial Unions Association (1883) 32 WR 262.

$52 \quad$ Ketteman $v$ Hansel Properties Ltd [1987] AC 189, 220.

53 Ibid.

54 Ibid.

55 Ibid. 
By the late 1980s, this broader perspective had reached the level of a 'quiet revolution'56 in Australian civil procedure. Courts moved away from a myopic focus on justice between the parties. Other matters became relevant: the cost and time involved in litigation, the interests of litigants waiting for their cases to be heard, and the responsible use of taxpayer funds. ${ }^{57}$ Consideration of these factors led judges to take a more active role in the pre-trial management of cases. ${ }^{58}$ Party control, which had for so long gone unquestioned, began to erode..$^{59}$ In short, most courts employed some form of case management in civil litigation.

Despite its widespread adoption, case management has its critics. Case management is supposed to save time and cost and increase rates of settlement. Yet there is very little empirical research bearing out the efficacy of case management. ${ }^{60}$ Former South Australian Chief Justice John Doyle pointed out that, in light of the fact that, since '[h]istory indicates that the vast majority of civil cases will settle without much management at all', it is doubtful whether today's high settlement rates are solely attributable to case management. ${ }^{61}$ Further, by requiring litigants to get their case in order at an early stage, and by requiring regular court attendances, case

56 Peter A Sallman, 'The Impact of Caseflow Management on the Judicial System' (1995) 18 University of New South Wales Law Journal 193, 194.

57 See State Pollution Control Commission v Australian Iron \& Steel Pty Ltd (1992) 29 NSWLR 487, 493 (Gleeson CJ); United Motors Retail Ltd v Australian Guarantee Corporation Ltd (1991) 58 SASR 156, 158 (King CJ); Tania Sourdin, 'Judicial Management and Alternative Dispute Resolution Trends' (1996) 14 Australian Bar Review 185, 187; Chief Justice JJ Spigelman, 'Forensic Accounting in an Adversary System' (Paper presented at the Fourth Annual National CA Forensic Accounting Conference, Sydney, 4 September 2003); Ipp, above n 33, 368.

58 Chief Justice John Doyle, 'The Machine of Justice - Who Is Driving It?' (2007) 28 Adelaide Law Review 7, 9; Spigelman, 'Forensic Accounting', above n 57, 2; Davies, 'Civil Justice Reform', above n 44, 181; Spigelman, 'Citizens, Consumers and Courts', above n 38, 5; Acting Justice Ronald Sackville, Foreword to Michael Legg, Case Management and Complex Civil Litigation (Federation Press, 2011), v.

$59 \quad$ See United Motors Retail Ltd v Australian Guarantee Corporation Ltd (1991) 58 SASR 156, 163 (Bollen J).

60 The Australian and Victorian Law Reform Commissions have called for empirical research to assess the effects of case management: Australian Law Reform Commission, Managing Justice: A Review of the Federal Civil Justice System, Report No 89 (2000), [6.30]; Victorian Law Reform Commission, Civil Justice Review Report (March 2008). Collen M Hanycz has argued that existing empirical studies focus on user satisfaction rather than the quality of outcomes: 'More Access to Less Justice: Efficiency, Proportionality and Costs in Canadian Civil Justice Reform' (2008) 27 Civil Justice Quarterly 98.

61 Chief Justice John Doyle, 'Imagining the Past, Remembering the Future - the Demise of Civil Litigation' ( (th $^{\text {th }}$ Gerard Brennan Lecture, delivered on 24 June 2011 at Bond University, Queensland), 4. 
management can increase the costs for the parties, ${ }^{62}$ albeit with the prospect of a swifter resolution. Case management also places demands upon the court; judges must devote considerable time to the management of cases. ${ }^{63}$ Proponents of case management acknowledge these difficulties but claim that case management delivers an overall net benefit to parties and to the system. ${ }^{64}$

More fundamental concerns have been raised about the compatibility of case management functions with the traditional role of the court. In her classic critique of case management, Judith Resnik invoked the ancient and enduring imagery of Justice as a goddess with scales, sword and blindfold to explain some key features of the judicial role:

The goddess herself - aloof and stoic - represents the physical and psychological distance between the judge and the litigants. Sometimes described as a virgin, Justice is unapproachable and incorruptible. The scales reflect evenhandedness and absolutism. The sword is a symbol of power and, like the scales, executes decisions without sympathy or compromise. Finally, the blindfold protects Justice from distractions and from information that could bias or corrupt her. Masked, Justice is immune from sights that could evoke sympathy in an ordinary spectator. ${ }^{65}$

Managerial judging, Resnik argued, threatened to qualitatively change the judicial role, removing the distance between judge and litigant and exposing the judge to a wealth of untested information about the case in advance of trial. Rather than simply determining the parties' legal rights based on evidence and legal argument, case managing judges must 'consider the parties' litigating strategies', and make

Productivity Commission, Access to Justice Arrangements: Draft Report (April 2014), 333-4; James S Kakalik et al, Just, Speedy and Inexpensive? An Evaluation of Judicial Case Management Under the Civil Justice Reform Act (Rand, 1996); John Peysner and Mary Seneviratne, The Management of Civil Cases: The Courts and Post-Woolf Landscape (UK Department of Constitutional Affairs, DCA Research Series 9/05, November 2005) 65-8, 71; Justice GL Davies, 'The Reality of Civil Justice Reform: Why We Must Abandon the Essential Elements of Our System' (2003) 12 Journal of Judicial Administration 155, 162; Doyle, 'Imagining the Past', above n 61, 7; IR Scott, 'Caseflow Management in the Trial Court' in AAS Zuckerman and Ross Cranston (eds), Reform of Civil Procedure: Essays on 'Access to Justice' (Clarendon Press, 1995) 1, 22; Craig Down, 'Crying Woolf? Reform of the Adversarial System in Australia' (1998) 7 Journal of Judicial Administration 213, 220; Acting Justice Ronald Sackville, 'Mega-Lit: Tangible Consequences Flow From Complex Case Management' (2010) Law Society Journal 47, 54; Legg, above n 36, 259; Australian Law Reform Commission, above n 60, [4.20]-[4.21].

63 Sackville, Foreword to Legg, above n 58, v; Sir Gerard Brennan, 'Key Issues in Judicial Administration' (1996) 6 Journal of Judicial Administration 138, 139-40; Scott, 'Caseflow Management', above n 62, 18.

64 Down, above n 62, 220; Woolf, Final Report, above n 38, 17; Sackville, 'Mega-Lit', above n 62, 54. 65 Resnik, above $\mathrm{n} 42,383$. 
decisions dictating the future course of the litigation. ${ }^{66}$ The overall effect is to strip the goddess Justitia of some of her defining features: 'Although the sword remains in place, the blindfold and scales have all but disappeared. ${ }^{\prime 67}$ In short, the role of a case managing judge is far removed from that of an 'aloof and stoic' arbiter of legal rights and liabilities.

Notwithstanding these criticisms, case management was well established in Australia by the early 1990s. ${ }^{68}$ The following observations of South Australia's King CJ show the extent to which courts had broadened their focus beyond the interests of the immediate parties to the case. Having noted the traditional view that amendments should be allowed as long as prejudice to the opposing party could be cured, ${ }^{69}$ his Honour explained:

The cases which focused on prejudice to the opposing party were decided, however, before the adoption by courts of modern principles of case flow management to enable them to cope with the volume of judicial business with the limited resources placed at their disposal. It is now well recognised throughout the judicial system that courts owe it to the community to adopt and apply effective procedures in order to make maximum use of the resources committed to them and to contain, so far as possible, the escalation of costs and delay. To that end principles of case flow management have been formulated and developed ...70

It can be seen that by this time, the Australian law of civil procedure was in a state of transition. Courts were moving away from a narrow focus on doing justice between the parties, and beginning to embrace case management as a way of implementing further goals of civil procedure: public justice and public efficiency. ${ }^{71}$

$66 \quad$ Ibid 393.

$67 \quad$ Ibid 431.

68 For an early discussion of the movement towards case management in Australia, see IR Scott, 'Is Court Control the Key to Reduction in Delays?' (1983) 57 Australian Law Journal 16, 22-3.

69 United Motors Retail Ltd v Australian Guarantee Corporation Ltd (1991) 58 SASR 156, 157, citing Clough and Rogers v Frog (1974) 48 ALJR 481.

(1991) 58 SASR 156, 158.

While the focus of this thesis is on civil procedure in Australia, similar trends can be observed in other common law countries. Notably, procedure in the UK has undergone fundamental reform following the Woolf and Jackson reforms: see Woolf, Interim Report, above n 30; Woolf, Final Report, above n 38; Lord Justice Jackson, Review of Civil Litigation Costs: Final Report (2009). These reforms have shifted the focus of civil procedure from the single aim of doing justice between the parties, to a broader concern with access to justice: see Woolf, Interim Report, above n 30, 24-5; Sorabji, above n 16. 


\section{CONCLUSION}

The story of civil procedure over the last 150 years is one of constant change. From the pre-Judicature Acts world of 'complexities and technicalities, anomalies and absurdities, archaic and even feudal practices ${ }^{\prime},{ }^{72}$ to the managerial judging of the late 20th century, procedure has developed in response to the needs of the justice system and the community. What does this brief history tell us about efficiency and justice in civil procedure? Pre-Judicature Acts English civil procedure lent itself to both injustice and inefficiency. Post-Judicature Acts procedure pursued justice between the parties to the virtual exclusion of other goals. With the rise of case management, judicial decisions on procedure began to acknowledge that procedure had other objectives, including public justice and public efficiency.

The focus of this thesis is on procedure in mega-litigation. The discussion in this chapter provides some insights into the way judges reconcile the objectives of justice and efficiency in mega-litigation. The case management movement suggests that judges have a responsibility to take control of mega-litigation in order to protect the interests of the public against the unbridled adversarialism of the parties. Case management offers a way of giving effect to public justice and public efficiency objectives, rather than only seeking to do justice between the parties.

Accepting that procedure has multiple objectives, however, only brings us back to the question of how to reconcile these objectives. When do considerations outside the interests of the parties become more important than the interests of those parties? How can judges, when making procedural decisions, decide where the balance lies? In the next chapter, I consider developments in Australian civil procedure since the early 1990s which have a bearing on these questions. Those developments consist of four cases in which the High Court has considered the role of case management; and the enactment of statutory 'overarching purpose' provisions embodying the philosophy of case management. 


\section{Chapter 7: Justice ANd EfFiciency in Civil Procedure: The CurRent Australian POSITION}

\section{INTRODUCTION}

The history of procedure is a series of attempts to solve the problems created by the preceding generation's procedural reforms. ${ }^{1}$

The previous chapter traced the history of civil procedure to the early 1990s. This chapter continues that history at a slower pace, and with a narrower focus: civil procedure in Australia, from the early 1990s to the present day. This chapter completes the foundations for the discussion, in Part III of this thesis, of the way in which judges reconcile the objectives of justice and efficiency in mega-litigation. When handling mega-litigation, judges are bound by the same procedural rules and principles that apply to ordinary litigation; therefore, the principles which inform contemporary Australian civil procedure also inform the way in which courts deal with mega-litigation. In addition, the way in which trial and appellate courts have sought to incorporate case management into the established procedural framework provides some striking illustrations of the range of approaches to questions about the relationship between justice and efficiency in civil procedure.

This chapter begins, in section II, with an outline of the influence of the Australian Constitution on civil procedure. This may seem to be a digression from the story of justice and efficiency in civil procedure. Yet the Constitution is an unavoidable part of the context in which Australian civil procedure operates. Chapter III of the Constitution places restrictions on the manner in which courts act, and is therefore crucial to understanding the limits within judges work when managing megalitigation.

Once the constitutional context is explained, section III of this chapter resumes the history of civil procedure, this time with an Australian focus. At the end of the last chapter, civil procedure was in a state of transition. Case management was becoming widely adopted as a response to the inefficiencies of the "justice on the merits' approach. But a century of thinking about procedure as primarily (almost solely) a tool for doing justice between the parties could not easily be discarded. The ideas of party control and judicial passivity, as well as the notion that justice should be done no matter what the cost, were deeply embedded in adversarial systems. Case management, developed as a series of ad-hoc responses to inadequacies in the existing system, sat uneasily alongside these adversarial principles.

Judith Resnik, 'Precluding Appeals' (1985) 70 Cornell Law Review 603, 624. 
Against this background, this chapter examines four decisions, over a span of 20 years, in which the High Court grappled with issues of justice, efficiency and case management: 1993's Sali v SPC Ltd; ${ }^{2}$ 1997's Queensland v JL Holdings Ltd; ${ }^{32009 ' s ~ A o n ~}$ Risk Services Australia Ltd v Australian National University; and 2013's Expense Reduction Analysts Group Pty Ltd v Armstrong Strategic Management and Marketing Pty Ltd. ${ }^{5}$ The 1993 decision in Sali (discussed in section III of this chapter) falls squarely within the trend of giving effect to case management considerations, rather than focussing narrowly on justice between the parties. The trajectory of the case law reversed, however, in 1997's JL Holdings. In that case (discussed in section IV) the High Court reaffirmed the paramountcy of justice between the parties, relegating case management principles to a peripheral role. Sections V and VI of this chapter discuss the consequences of JL Holdings. Section $\mathrm{V}$ demonstrates that judges in trial courts applied the JL Holdings reasoning to a wide range of cases, with some undesired consequences. Parties and lawyers took a relaxed approach to compliance with procedural rules and directions, safe in the knowledge that non-compliance would be forgiven if necessary to do justice between the parties. Courts reacted to this attitude by enacting court rules and legislation expressly permitting judges to consider matters beyond the interests of the parties. I discuss these provisions in section VI. Section VII considers the High Court's response to these developments in Aon. In this case, the High Court rejected the JL Holdings reasoning and adopted an approach to procedure that incorporates considerations of public justice and public efficiency as well as justice between the parties. The most recent case, Expense Reduction (discussed in section VIII of this chapter), reaffirmed this broader approach to 'justice' in civil procedure.

\section{Constitutional Limits ON Civil Procedure}

One aim of this chapter is to explain the legal context in which Australian judges make decisions about civil procedure. The picture would be incomplete without reference to constitutional constraints on the actions of Australian courts. It should be apparent from this chapter (as well as Chapter 6) that civil procedure has gone through some fundamental changes over the last century. In Part III of this thesis, I will show that judges are using innovative techniques to deal with mega-litigation, and that further change may be needed. But there are limits on the innovation that is permissible. Chapter III of the Constitution imposes restrictions on court procedure.

\footnotetext{
(1993) 67 ALJR 841 ('Sali').

(1997) 189 CLR 146 ('JL Holdings').

(2009) 239 CLR 175 ('Aon').

(2013) 250 CLR 303 ('Expense Reduction').
} 
Those requirements have been the subject of substantial academic commentary. ${ }^{6}$ For the purposes of this thesis, it is sufficient to give a relatively brief account of the constitutional requirements of court procedure.

The Constitution contains no express 'due process' clause analogous to the 14th amendment to the United States Constitution. However, there are implied Constitutional requirements relating to procedure in both federal and State courts. The term 'due process' is used ${ }^{7}$ as 'a convenient label for describing aspects of the judicial process that attract constitutional protection' ${ }^{8}$ It is in that sense that I will use the term in this thesis. The source and content of the 'due process' requirements that apply to federal courts are different from those that apply to State courts. I will consider each in turn.

\section{A Federal Courts}

The strict separation of federal judicial power from the legislative and executive branches of government means that federal courts may only exercise federal judicial power. ${ }^{9}$ In a series of judgments in the 1990s, Gaudron J developed the idea that 'an essential feature of judicial power is that it be exercised in accordance with the judicial process'. ${ }^{10}$ In Nicholas $v$ The Queen, ${ }^{11}$ her Honour said:

Fiona Wheeler, 'The Doctrine of Separation of Powers and Constitutionally Entrenched Due Process in Australia' (1997) 23 Monash University Law Review 248; Fiona Wheeler, 'Due Process, Judicial Power and Chapter III in the New High Court' (2004) 32 Federal Law Review 205; Will Bateman, 'Procedural Due Process Under the Australian Constitution' (2009) 31 Sydney Law Review 411; Sarah Murray, The Remaking of the Courts: Less-Adversarial Practice and the Constitutional Role of the Judiciary in Australia (Federation Press, 2014); James Stellios, The Federal Judicature: Chapter III of the Constitution (LexisNexis Butterworths, 2010), ch 6; Justice Michael McHugh, 'Does Chapter III of the Constitution Protect Substantive as Well as Procedural Rights?' (2001) 21 Australian Bar Review 235; Leslie Zines, The High Court and the Constitution (Federation Press, $5^{\text {th }}$ ed, 2008), 273-9; Christine Parker, 'Protection of Judicial Process as an Implied Constitutional Principle' (1994) 16 Adelaide Law Review 341; Enid Campbell, 'Rules of Evidence and the Constitution' (2000) 26 Monash University Law Review 313; Wendy Lacey, 'Inherent Jurisdiction, Judicial Power and Implied Guarantees Under Chapter III of the Constitution' (2003) 31 Federal Law Review 57; George Williams and David Hume, Human Rights Under the Australian Constitution (Oxford University Press, 2nd ed, 2013) 365-79.

$7 \quad$ See, eg, Re Tracey; Ex parte Ryan (1989) 166 CLR 518, 580 (Deane J); Wheeler, 'The Doctrine of Separation of Powers', above n 6; Wheeler, 'Due Process, Judicial Power and Chapter III', above n 6; Stellios, above n 6, ch 6; McHugh, above n 6, 238; George Winterton, 'The Separation of Judicial Power as an Implied Bill of Rights' in Geoffrey Lindell (ed), Future Directions in Australian Constitutional Law (Federation Press, 1994) 185, 200; Zines, above n 6, 273-9; Williams and Hume, above n 6, 365.

8 Stellios, above n 6, 275; Wheeler, 'Due Process, Judicial Power and Chapter III', above n 6, 211.

$9 \quad$ R v Kirby; Ex parte Boilermakers Society of Australia (1956) 94 CLR 254.

$10 \quad$ Polyukhovich $v$ Commonwealth (1991) 172 CLR 501, 703. See also Harris $v$ Caladine (1991) 172 CLR 84, 150 (Gaudron J); Re Nolan; Ex parte Young (1991) 172 CLR 460, 496; Nicholas $v$ The Queen 
Judicial power is not adequately defined solely in terms of the nature and subject matter of determinations made in exercise of that power. It must also be defined in terms that recognise it is a power exercised by courts and exercised by them in accordance with the judicial process. ${ }^{12}$

In other words, judicial power, which is vested exclusively in Chapter III courts, encompasses not only what courts do, but also how they do it. It follows that federal courts cannot be 'required or authorised to proceed in a manner' contrary to the judicial process. ${ }^{13}$ To do so would involve a federal court in the exercise of nonjudicial power.

While Gaudron J was developing this idea, other members of the Court, led by Deane J, were exploring an alternative basis for the constitutional protection of court process. This involved giving substantive meaning to the word 'court', ${ }^{14}$ which is used throughout Chapter III. ${ }^{15}$ In Polyukhovich $v$ Commonwealth, ${ }^{16}$ Deane J drew on the objective of the separation of powers - ensuring that individual rights are regulated by the rule of law rather than the exercise of arbitrary power - to explain why court process was constitutionally protected:

That objective will, of course, be achieved by the Constitution's requirement that judicial power be vested exclusively in the courts which it designates if the judicial power so vested is exercised by those courts in accordance with the essential attributes of the curial process. Indeed, to construe Ch III of the Constitution as being concerned only with labels and as requiring no more than that the repository of judicial power be called a court would be to convert it into a mockery, rather than a reflection, of the doctrine of separation of powers. Common sense and the provisions of Ch III, based as they are on the assumption of traditional judicial procedures, remedies and methodology ... compel the conclusion that, in insisting that the judicial power of the Commonwealth be vested only in the courts designated by Ch III, the Constitution's intent and

(1998) 193 CLR 173, 208 (Gaudron J). This position was endorsed by a majority of the High Court in Bass v Permanent Trustee Co Ltd (1999) 198 CLR 334, 359 (Gleeson CJ, Gaudron, McHugh, Gummow, Hayne and Callinan JJ).

11 (1998) 193 CLR 173.

$12 \quad$ Ibid 208.

13 Ibid.

$14 \quad$ Polyukhovich $v$ Commonwealth (1991) 172 CLR 501, 607 (Deane J); Chu Kheng Lim v Minister for Immigration, Local Government and Ethnic Affairs (1992) 176 CLR 1, 27 (Brennan, Deane and Dawson JJ); Leeth $v$ Commonwealth (1992) 174 CLR 455, 486-7 (Deane and Toohey JJ).

15 Sections $71,72,73,77$ and 79.

$16 \quad$ (1991) 172 CLR 501. 
meaning were that that judicial power would be exercised by those courts acting as courts with all that that notion essentially requires. ${ }^{17}$

In Leeth $v$ Commonwealth, ${ }^{18}$ Toohey J joined Deane $\mathrm{J}$ in a joint judgment explaining that the references to 'courts' in Chapter III did more than

identify the possible repositories of Commonwealth judicial power. They also dictate and control the manner of its exercise. They are not concerned with mere labels or superficialities. They are concerned with matters of substance. Thus, in Ch III's exclusive vesting of the judicial power of the Commonwealth in the 'courts' which it designates, there is implicit a requirement that those 'courts' exhibit the essential attributes of a court and observe, in the exercise of that judicial power, the essential requirements of the curial process, including the obligation to act judicially. ${ }^{19}$

On this view, judicial process was protected not by the references to 'judicial power' in Ch III, but by a separate implication drawn from the references to 'courts'. The basis of the 'due process' implication remains uncertain. ${ }^{20}$ Members of the High Court (including both Deane and Gaudron JJ) have tended to conflate the two bases by, for example, stating that $\mathrm{Ch}$ III courts cannot be required 'to exercise judicial power in a manner which is inconsistent with the essential character of a court or with the nature of judicial power. ${ }^{21}$ For the purposes of this thesis, the source of the implication is less important than its content.

In Re Nolan; Ex parte Young, Gaudron J identified the general features of the judicial process that attract the protection of the 'due process' principle:

$17 \quad$ Ibid 607 (emphasis added, citations omitted).

$18 \quad$ (1992) 174 CLR 455.

19 Leeth $v$ Commonwealth (1992) 174 CLR 455, $486-7$ (emphasis added, citations omitted).

20 See Stellios, above n 6, 278; Wheeler, 'Due Process, Judicial Power and Chapter III', above n 6, 210; Bateman, above n 6, 428-34.

$21 \quad$ Chu Kheng Lim v Minister for Immigration, Local Government and Ethnic Affairs (1992) 176 CLR 1, 27 (Brennan, Deane and Dawson JJ) (emphasis added). See also Nicholas $v$ The Queen (1998) 193 CLR 173, 185 (Brennan CJ) ('Consistency with the essential character of a court or with the nature of judicial power'), 208 (Gaudron J) ('consistency with the essential character of a court and with the nature of judicial power'); Polyukhovich $v$ Commonwealth (1991) 172 CLR 501, 607 (Deane J) ('inconsistent with the essential requirements of a court or with the nature of judicial power'); APLA Ltd v Legal Services Commissioner (NSW) (2005) 224 CLR 322, 411 (Gummow J) ('inconsistent with the essential character of a court or with the nature of judicial power'); Thomas $v$ Mowbray (2007) 233 CLR 307, 355 (Gummow and Crennan JJ) ('inconsistent with the essential character of a court or with the nature of judicial power'). See also TCL Air Conditioner (Zhongshan) Co Ltd $v$ The Judges of the Federal Court of Australia (2013) 87 ALJR 410, 419-20 [27]. 
[T]hose features include open and public enquiry (subject to limited exceptions), the application of the rules of natural justice, the ascertainment of the facts as they are and as they bear on the right or liability in issue and the identification of the applicable law, followed by an application of that law to those facts. ${ }^{22}$

Another key statement of the content of the due process principle is that of Gleeson CJ, Gaudron, McHugh, Gummow, Hayne and Callinan JJ in Bass v Permanent Trustee Co Ltd:

Judicial power involves the application of the relevant law to facts as found in proceedings conducted in accordance with the judicial process. And that requires that the parties be given an opportunity to present their evidence and to challenge the evidence led against them. ${ }^{23}$

Within these limits, however, Chapter III does not require procedures to be frozen in time. The High Court has repeatedly confirmed that Parliament, and courts themselves, are able to introduce new procedures, and change the rules of evidence and procedure. ${ }^{24}$ This should not be surprising; as we saw in the previous chapter, an examination of the history of civil procedure reveals 'a dynamic landscape of constant change. ${ }^{25}$ History can be used as a guide in determining which procedures are constitutionally permissible. But in this context the High Court has tended to use historical analogues to aid them in finding that controversial provisions are valid, ${ }^{26}$ rather than holding novel procedures invalid because of their departure from historical norms.

In practice, the most significant effect of the due process principle on civil procedure may be the entrenchment of the rules of procedural fairness in federal courts. Assessments of the content of the due process principle often begin by recognising that, at the very least, the principle protects the rules of procedural fairness or

22 Re Nolan; Ex parte Young (1991) 172 CLR 460, 496. This statement of the features of the judicial process has been approved in subsequent cases: see Condon v Pompano Pty Ltd (2013) 228 A Crim R 237, 281 [142] (Hayne, Crennan, Kiefel and Bell JJ). See also Gaudron J's statement of the scope of the due process principle in Nicholas $v$ The Queen (1998) 193 CLR 173, 208-9.

23 (1999) 198 CLR 334, 359 (citations omitted).

24 See In Re Judiciary and Navigation Acts (1921) 29 CLR 257, 266 (Knox CJ, Gavan Duffy, Powers, Rich and Starke JJ); Commonwealth v Melbourne Harbour Trust Commissioners (1922) 31 CLR 1, 12, 17; Williamson v Ah On (1926) 39 CLR 95; Nicholas v The Queen (1998) 193 CLR 173, 188-9, 202-3, 225, 260, 273.

25 Bateman, above n 6, 431. See also Federal Court of Australia, Case Management Handbook (13 October 2011) 10 [2.13].

26 See, eg, Thomas v Mowbray (2007) 233 CLR 307; Gypsy Jokers Motorcycle Club Inc v Commissioner of Police (2008) 234 CLR 532; TCL Air Conditioner (Zhongshan) Co Ltd v The Judges of the Federal Court of Australia (2013) 87 ALJR 410, 431-2 [105]; Bateman, above n 6, 430-1. 
natural justice. ${ }^{27}$ Procedural fairness has been described as the " line in the sand" circumscribing the judicial role', ${ }^{28}$ and as the 'heartland' ${ }^{29}$ or 'core requirement' ${ }^{30}$ of the due process principle. Procedural fairness encompasses two different rules: the hearing rule and the rule against bias. While the due process principle, at the federal level, permits innovation in civil procedure, any encroachment on the rules of procedural fairness will raise a constitutional issue.

\section{B State Courts}

The source and content of the constitutional restrictions on court procedure in State courts are different from those that operate at the Federal level. There is no separation of powers at the state level. ${ }^{31}$ It is constitutionally permissible for state courts to perform some non-judicial functions. ${ }^{32}$ However, there is a limit on the functions that may be conferred on State courts. This limit, first recognised in Kable $v$ Director of Public Prosecutions (NSW), ${ }^{33}$ arises from the integrated nature of the Australian judicial system and from the provision, in s 77(iii) of the Constitution, for State courts to exercise the judicial power of the Commonwealth.

Recent statements of the Kable principle focus on its protection of the 'institutional integrity' of State courts. ${ }^{34}$ This means that, much like federal courts, State courts must retain the essential, or defining, characteristics of 'courts'. In Forge $v$ Australian Securities and Investments Commission, 35 Gummow, Hayne and Crennan JJ explained that:

27 Wheeler, 'The Doctrine of Separation of Powers', above n 6, 251; Bateman, above n 6, 415; Australian Law Reform Commission, Managing Justice: A Review of the Federal Civil Justice System, Report No 89 (2000), [1.144]; Stellios, above n 6, 292; Winterton, above n 7, 200; Federal Court of Australia, above n 25, 6 [1.4].

28 Australian Law Reform Commission, above n 27, [1.144].

29 Wheeler, 'The Doctrine of Separation of Powers', above n 6, 252.

30 Stellios, above n 6, 292.

$31 \quad$ Kable v Director of Public Prosecutions (NSW) (1996) 189 CLR 51; Wainohu v New South Wales (2011) 243 CLR 181, 192 [7].

32 See, eg, Momcilovic v The Queen (2011) 245 CLR 1 (French CJ); Kable v Director of Public Prosecutions (NSW) (1996) 189 CLR 51, 117 (McHugh J).

33 (1996) 189 CLR 51 ('Kable').

34 Fardon v Attorney-General (Qld) (2004) 223 CLR 575, 617 (Gummow J); Momcilovic v The Queen (2011) 245 CLR 1, 66-7 [93] (French CJ), 224-5 [593] (Crennan and Kiefel J); Wainohu v New South Wales (2011) 243 CLR 181, 208-9 [44] (French CJ and Kiefel J); South Australia v Totani (2010) 242 CLR 1, 47-8 [69] (French CJ), 67 [149] (Gummow J), 82 [205] (Hayne J), 160 [436] (Crennan and Bell JJ); Condon v Pompano Pty Ltd (2013) 228 A Crim R 237, 261 [67] (French CJ), 276 [123] (Hayne, Crennan, Kiefel and Bell JJ). 
Because Ch III requires that there be a body fitting the description 'the Supreme Court of a State', it is beyond the legislative power of a State so to alter the constitution or character of its Supreme Court that it ceases to meet the constitutional description. ... [T] he relevant principle [in Kable] is one which hinges upon maintenance of the defining characteristics of a 'court', or in cases concerning a Supreme Court, the defining characteristics of a State Supreme Court. It is to those characteristics that the reference to 'institutional integrity' [in Kable cases] alludes. That is, if the institutional integrity of a court is distorted, it is because the body no longer exhibits in some relevant respect those defining characteristics which mark a court apart from other decision-making bodies. ${ }^{36}$

More recently, French CJ and Kiefel J have made the same link between institutional integrity and the notion of 'courts', stating that 'The term 'institutional integrity', applied to a court, refers to its possession of the defining or essential characteristics of a court.' ${ }^{37}$ Therefore, to the extent that court procedure constitutes a defining characteristic of a court, it is subject to some measure of constitutional protection at state level.

The case law confirms that interference with the judicial process is relevant to the Kable analysis. In two recent cases, the fact that legislation authorised a departure from the judicial process was a reason for holding the legislation invalid. ${ }^{38}$ In Kable itself, the reasons for finding that the legislation was invalid included not just the nature of the jurisdiction conferred on the Supreme Court of New South Wales - ad hominem preventative detention - but also the fact that the jurisdiction was to be exercised in a way that did not conform to the usual judicial process. ${ }^{39}$ In Fardon, a different scheme of preventative detention was held valid. One reason for distinguishing Kable was that, unlike the legislation held invalid in Kable, the impugned legislation preserved traditional elements of court procedure: the rules of evidence applied and hearings were to be conducted in public in accordance with the usual judicial process. ${ }^{40}$

For the purposes of this thesis, the most significant limit of the Kable principle on efficiency-driven developments in civil procedure is - as for federal courts - the protection of procedural fairness. Several members of the High Court have stated

\footnotetext{
$36 \quad$ Ibid 76.

37 Wainohu $v$ New South Wales (2011) 243 CLR 181, 208 [44]. See also Condon v Pompano Pty Ltd (2013) 228 A Crim R 237, 261 [67] (French CJ).

$38 \quad$ International Finance Trust Ltd v New South Wales Crime Commission (2009) 240 CLR 319; Wainohu $v$ New South Wales (2011) 243 CLR 181. Cf Condon v Pompano Pty Ltd (2013) 228 A Crim R 237. (1996) 189 CLR 51, 122 (McHugh J), 108 (Gaudron J). Fardon v Attorney-General (Qld) (2004) 223 CLR 575, 592 (Gleeson CJ).
} 
expressly that fairness, ${ }^{41}$ procedural fairness ${ }^{42}$ or the hearing rule ${ }^{43}$ are among the defining characteristics of courts. There are also many statements that Kable requires state courts to be independent and impartial ${ }^{44}$ - statements which can be interpreted as entrenching the bias rule at the State level. ${ }^{45}$

There is general agreement, then, that the Kable principle provides some measure of protection of procedural fairness in State courts. It does not follow, however, that a departure from the rules of procedural fairness in a State court will necessarily infringe the Kable principle. On the contrary, legislation abrogating the hearing rule in State courts has been held valid. ${ }^{46}$ The Kable principle is likely to be engaged when a departure from established judicial process is accompanied by other features, such as dictation to the court by the executive, or an unacceptably close relationship between the executive and the judiciary. ${ }^{47}$ Further, legislation held to breach the Kable principle has generally involved some interference by the State with individual liberty or property rights. ${ }^{48}$ Mega-litigation, the subject of this thesis, is litigation between individuals or corporations, not necessarily involving government parties. Changes to procedure in this kind of litigation are less likely to breach the

$41 \quad$ South Australia v Totani (2010) 242 CLR 1, 43 [62] (French CJ).

42 Hogan v Hinch (2011) 243 CLR 506, 541 [45] (French CJ); Wainohu v New South Wales (2011) 243 CLR 181, 208 [44] (French CJ and Kiefel J); Condon v Pompano Pty Ltd (2013) 228 A Crim R 87, 261 [67] (French CJ).

43 International Finance Trust Company Ltd v New South Wales Crime Commission (2009) 240 CLR 319, 354 [54] (French CJ), 379-81 [140]-[145] (Heydon J); South Australia v Totani (2010) 242 CLR 1, 43 [62] (French CJ).

44 See, eg, North Australian Aboriginal Legal Aid Service v Bradley (2004) 218 CLR 146, 163 [29] (McHugh, Gummow, Kirby, Hayne, Callinan and Heydon JJ); Forge v Australian Securities and Investments Commission (2006) 228 CLR 45, 67-8 [41] (Gleeson CJ), 76 [64] (Gummow, Hayne and Crennan JJ); Gypsy Jokers Motorcycle Club Inc v Commissioner of Police (2008) 234 CLR 532, 552-3 [10] (Gummow, Hayne, Heydon and Kiefel JJ); Wainohu v New South Wales (2011) 243 CLR 181, 208; South Australia v Totani (2010) 242 CLR 1, 43 [62], 157 [427]; Condon v Pompano Pty Ltd (2013) 228 A Crim R 87, 261 [67] (French CJ), 276 [125] (Hayne, Crennan, Kiefel and Bell JJ).

45 See Ebner v Official Trustee in Bankruptcy (2000) 205 CLR 337, 363 (Gaudron J), 373 (Kirby J).

46 Gypsy Jokers Motorcycle Club Inc v Commissioner of Police (2008) 234 CLR 532; K-Generation Pty Ltd $v$ Liquor Licensing Court (2009) 237 CLR 501; Condon v Pompano Pty Ltd (2013) 228 A Crim R 87. For a contrary point of view, see Condon v Pompano Pty Ltd (2013) 228 A Crim R 87, 291-3 [189][194] (Gageler J).

47 Cf Momcilovic $v$ The Queen (2011) 245 CLR 1, 226 [597] (Crennan and Kiefel JJ) (reasoning that legislation did not breach the Kable principle because it did not enlist the Court in a legislative or executive scheme).

48 In Kable itself the legislation allowed for detention of an individual; in Wainohu v New South Wales (2011) 243 CLR 181 and South Australia $v$ Totani (2010) 242 CLR 1, individuals' freedom of association was restricted; and in International Finance Trust Company Ltd $v$ New South Wales Crime Commission (2009) 240 CLR 319 the legislation empowered the State to restrain, and ultimately confiscate, private property. 
Kable principle than changes to the way courts adjudicate cases affecting individual liberty. For these reasons, State courts have more scope for departure from established judicial procedure than their federal counterparts.

The constitutional limits on civil procedure - at either the federal or State level cannot be explained in precise terms. The validity of any particular procedure, or legislative change, will depend on the circumstances. In this thesis, I will deal with constitutional 'due process' considerations as they arise. This is not a constitutional law thesis, but constitutional principles do impose limits on the extent to which courts can adapt their procedures to pursue the ends of efficiency, and to deal with mega-litigation.

Having set out the constitutional context within which Australian courts operate, I will now examine some of the key developments in Australian civil procedure since the early 1990s. The first of these developments was the High Court's 1993 decision in Sali.

\section{SALI: ${ }^{49}$ CASE MANAGEMENT VALIDATED}

In Sali, a majority of the High Court endorsed case management principles for the first time. ${ }^{50}$ The case concerned a refusal by the Full Court of the Supreme Court of Victoria to adjourn an appeal hearing. The hearing was listed at relatively short notice, as part of a 'Spring Offensive' in which the Supreme Court 'devoted itself to getting rid of as many civil cases as they possibly could in the space of about two months. ${ }^{51}$ The appellant apparently had difficulty engaging senior counsel and, on the day of the appeal, was represented by junior counsel who was not briefed in the appeal and only had instructions to seek an adjournment of two weeks. The Full Court refused to grant the adjournment and the appeal was effectively terminated without a hearing.

The High Court dismissed an appeal by 3:2. Toohey and Gaudron JJ, in dissent, found that the Full Court ought to have granted an adjournment of several hours for the appellant to seek to engage senior counsel. Their Honours' reasoning on the

\section{(1993) 67 ALJR 841.}

50 This was not, however, the first time that case management considerations had been mentioned in a High Court judgment. In Squire v Rogers (1979) 39 FLR 106, 113-14, Deane J had noted that a decision whether to grant an adjournment may involve the assessment of competing claims by litigants in other cases awaiting hearing in the list of the particular judge or the particular court and may require knowledge of the working of the listing system of the particular court or judge and the importance in the proper working of that system of adherence to dates fixed for hearing. 
relevant principles is substantially similar to that of the majority (Brennan, Deane and McHugh JJ).

The settled principles on adjournments were typical of the approach that prioritises justice between the parties above all else. If an adjournment was necessary to avoid serious injustice to a party, then it ought to be granted unless doing so would cause injustice to another party to the case. ${ }^{52}$ In Sali, both the majority and the minority explained that these principles must be adapted to changing times. Brennan, Deane and McHugh JJ said that the principles

were formulated when court lists were not as congested as they are today and the concept of case management had not developed into the sophisticated art that it has now become. ${ }^{53}$

The emergence of case management meant that courts were entitled to take additional factors into consideration in the exercise of their discretion in procedural matters:

In determining whether to grant an adjournment, the judge of a busy court is entitled to consider the effect of an adjournment on court resources and the competing claims by litigants in other cases awaiting hearing in the court as well as the interests of the parties. ${ }^{54}$

In this passage, Brennan, Deane and McHugh JJ acknowledge that public justice and public efficiency are legitimate aims of civil procedure. Similarly, Toohey and Gaudron JJ said that '[ $\mathrm{t}]$ he contemporary approach to court administration' had introduced a new factor to be taken into account in the exercise of the discretion to grant adjournments:

The view that the conduct of litigation is not merely a matter for the parties but is also one for the court and the need to avoid disruptions in the court's lists with consequent inconvenience to the court and prejudice to the interests of other litigants waiting to be heard are pressing concerns to which a court may have regard. 55

The judgments send a clear message that justice between the parties is not the sole consideration of civil procedure. 
While the outcome in Sali turned on its facts, ${ }^{56}$ the judgments sent a clear message that case management had a legitimate and significant role in Australian civil procedure. Brennan, Deane and McHugh JJ explained that the traditional focus on justice between the parties was no longer adequate; broader interests must be taken into account:

What might be perceived as an injustice to a party when considered only in the context of an action between parties may not be so when considered in a context which includes the claims of other litigants and the public interest in achieving the most efficient use of court resources. ${ }^{57}$

Significantly, this quote indicates that the majority did not see case management as opposed to justice. Instead, their Honours took a much broader view of justice, encompassing the interests of the public as well as the parties.

\section{JL HOLDINGS: ${ }^{58}$ JUSTICE IS PARAMOUNT}

In Sali the High Court endorsed case management techniques and downplayed the role of justice between the parties. Less than four years later, in JL Holdings, the 'pendulum swung the other way',59 with the High Court insisting that justice between the parties was the 'paramount' 60 consideration in the exercise of a procedural discretion.

JL Holdings came to the High Court as a dispute about a late application to amend pleadings. The substantive case concerned the failure of the Queensland Minister of Lands to endorse a lease entered into by JL Holdings Pty Ltd with the Brisbane City Council. Under the Land Act 1962 (Qld), the lease had no effect without the Minister's endorsement. The then-Minister had given written approval to a proposed lease but his successor in office had refused formally to endorse the lease. JL Holdings sued the State of Queensland and associated parties in the Federal Court, claiming that once written consent had been given, the Minister was obliged to give formal endorsement. The respondents denied that any such obligation existed. ${ }^{61}$

\footnotetext{
56 The appellant's conduct involved, in the Full Court's view, an extreme instance of tactical delaying tactics. In the High Court, Toohey and Gaudron JJ did not agree that the application was a mere tactical device, and dissented on this basis: Sali (1993) 67 ALJR 841, 848.

57 Ibid 844 (Brennan, Deane and McHugh JJ).

$58 \quad$ (1997) 189 CLR 146.

59 Justice John P Hamilton, 'Thirty Years of Civil Procedure Reform in Australia: A Personal Reminiscence' (2005) 26 Australian Bar Review 258, 265.

$60 \quad J L$ Holdings (1997) 189 CLR 146, 155.

61 Ibid 150-1.
} 
The matter was listed for trial before Kiefel J, with an estimated hearing time of four months. ${ }^{62}$ At a directions hearing six months before the trial was to commence, the respondents sought to amend their pleadings to introduce an alternative defence, alleging that the lease to which the Minister had given written approval was different from the final lease executed by the parties. ${ }^{63}$ The reason for the lateness of the application to amend was that the information had only recently been discovered. ${ }^{64}$ Kiefel J refused to allow the amendment. The 'most relevant consideration' in her Honour's decision was that the amendment would put the trial date in jeopardy, with a new trial unlikely to be possible until the following year. ${ }^{65}$

The Full Court of the Federal Court dismissed an appeal. ${ }^{66}$ Having referred to the 1884 decision in Cropper $v$ Smith $^{67}$ and the 1974 decision in Clough and Rogers v Frog68 (both of which indicated that the amendment should be allowed), the majority said a new approach was needed: 'times have changed since 1884, and even since $1974{ }^{\prime} .{ }^{69}$ Relying on the remarks of Toohey and Gaudron JJ in Sali to the effect that the interests of other litigants and inconvenience to the court were relevant considerations, ${ }^{70}$ the majority concluded:

Unless we are to mouth the repeated cautions about discretionary judgments, case management, efficiency, practice and procedure, and the advantages of the managing judge, only to ignore them when it comes to the crunch, this appeal must be dismissed. ${ }^{71}$

This position accepts the force of efficiency considerations in procedural judgments. It illustrates the implications of Sali's conclusion that considerations of justice and efficiency from the public point of view are relevant to procedural discretion: those considerations can, in an appropriate case, override the interests of justice between the parties.

In allowing an appeal from the Full Court's decision (and in doing so, holding that the amendment ought to have been allowed), the High Court backed away from its

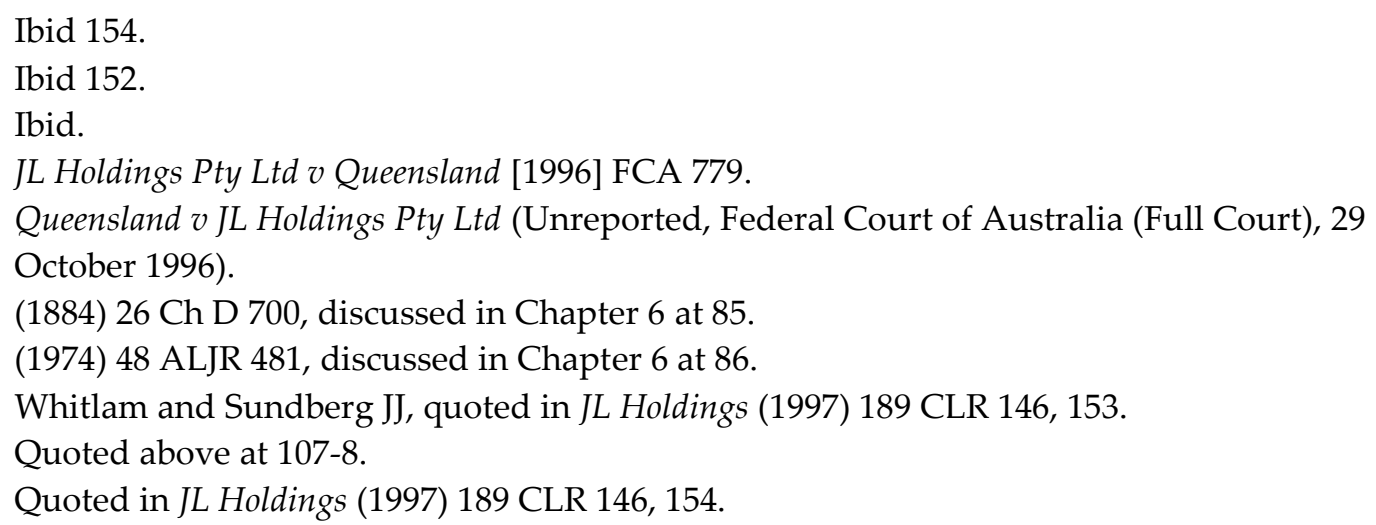


endorsement of case management in Sali. Dawson, Gaudron and McHugh JJ said the remarks of Toohey and Gaudron JJ in Sali, on which the Full Court had relied, were 'not to be taken as sanctioning any departure from the principles established in Cropper $v$ Smith and accepted in Clough and Rogers $v$ Frog. ${ }^{72}$ In a key passage, their Honours explained that nothing in Sali could be taken as meaning that case management principles

might be employed, except perhaps in extreme circumstances, to shut a party out from litigating an issue which is fairly arguable. Case management is not an end in itself. It is an important and useful aid for ensuring the prompt and efficient disposal of litigation. But it ought always to be borne in mind, even in changing times, that the ultimate aim of a court is the attainment of justice and no principle of case management can be allowed to supplant that aim. ${ }^{73}$

This passage effectively confined the application of Sali to 'extreme circumstances'. While accepting that case management may have a role to play, their Honours reject the notion that the pressures of modern litigation have changed the fundamental goal of procedural law. That goal, which draws on deeply held beliefs about the role of courts, is to do justice. For Dawson, Gaudron and McHugh JJ, 'justice' appeared to mean only justice between the parties.

Applying this approach to the facts of this case, their Honours noted that the amendment was sought six months before the proposed trial date. Significantly, the proposed amendment constituted 'a substantial, if not complete answer to [JL Holdings'] claim. ${ }^{\prime 74}$ The Cropper $v$ Smith principles, therefore, required that the amendment be allowed: 'If it is arguable, the applicants should be permitted to argue it, provided that any prejudice to [JL Holdings] might be compensated by costs. ${ }^{75}$ On the latter point, Dawson, Gaudron and McHugh JJ noted, but placed minimal weight on, statements in authorities such as Ketteman ${ }^{76}$ that costs are inadequate compensation for the non-financial strain caused by litigation. ${ }^{77}$ In a case involving only commercial and government parties, 'there is nothing which would

JL Holdings (1997) 189 CLR 146, 154.

Ibid (emphasis added).

Ibid.

Ibid. The 'applicants' referred to in this passage are the State of Queensland and the South Bank Corporation; respondents in the action itself but applicants in the application to amend. Ketteman $v$ Hansel Properties Ltd [1987] AC 189, discussed in Chapter 6 at 91-2. JL Holdings (1997) 189 CLR 146, 155, referring also to Commonwealth $v$ Verwayen (1990) 170 CLR 394, 464-5 and 482. 
indicate any personal strain which would justify the conclusion that costs are not an adequate remedy for prejudice'. ${ }^{78}$ Their Honours concluded:

Justice is the paramount consideration in determining an application such as the one in question. ... Case management, involving as it does the efficiency of the procedures of the court, was in this case a relevant consideration. But it should not have been allowed to prevail over the injustice of shutting the applicants out from raising an arguable defence, thus precluding the determination of an issue between the parties. ${ }^{79}$

Once again, this passage reflects a strong view about the proper role of the court. Doing justice, in the sense of determining all the issues between the parties, is 'paramount'. Their Honours, despite accepting that efficiency considerations are 'relevant', did not appear to envisage a significant role for these considerations, except in 'extreme' cases. If justice is paramount, and if efficiency cannot be used as a reason to prevent a party from litigating an arguable issue, then efficiency considerations will have little bearing on most procedural decisions. The result may be that, as the Full Court of the Federal Court suggested, ${ }^{80}$ judges can do no more than pay lip service to the desirability of efficiency and the interests of other litigants.

In a separate concurring judgment in JL Holdings, Kirby $\mathrm{J}$ was more alert to considerations of public justice and public efficiency. On the facts, his Honour found that Kiefel J's discretion had miscarried and that the appeal should be allowed. But Kirby J considered several factors, including case management considerations, relevant to the exercise of the discretion to permit amendments. ${ }^{81}$ Importantly, these factors went beyond the objective of doing justice between the parties:

A court must accord justice to the particular litigant. But it must also maintain its responsible use of scarce public resources and consider, in a general way, the impact which its orders have on other litigants and on the public generally. ${ }^{82}$

Kirby J, then, thought that public justice (the interests of other litigants and the general public) and public efficiency ('responsible use of scarce public resources'), as well as justice between the parties, were relevant to the exercise of the discretion. The judge's duty was to balance the relevant factors in any procedural decision:

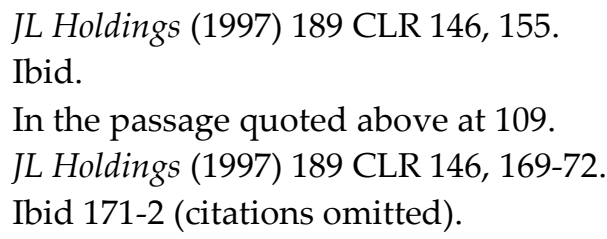


Whilst taking all of the considerations relevant to the circumstances of the case into account, the judge must always be careful to retain that flexibility which is the hallmark of justice. New considerations for the exercise of judicial discretion in such cases have been identified in recent years. But the abiding judicial duty remains the same. A judge who ignores the modern imperatives of the efficient conduct of litigation may unconsciously work an injustice on one of the parties, or litigants generally, and on the public. But a judge who applies case management rules too rigidly may ignore the fallible world in which legal disputes arise and in which they must be resolved..$^{83}$

In this passage, Kirby J acknowledged that the considerations relevant to the exercise of a procedural discretion have changed with the times. But his Honour insists that the ultimate task of the court is still the same: doing justice. The idea of justice, though, is expanded to include what I have called 'public justice'. I argue that Kirby J's position represents a significant shift in the role of the court: from doing justice between the parties to doing justice to the community. To say that the 'abiding judicial duty remains the same' ignores the significance of this change.

In JL Holdings the High Court retreated from Sali's acceptance of the importance of efficiency considerations in procedural decision-making, and to reassert the traditional paramountcy of justice between the parties. This retreat reflects, perhaps, the deep attractiveness of the idea that courts exist in order to do justice between the parties. However, as I argue throughout this thesis, civil procedure is capable of serving multiple aims. The sidelining of all aims except justice between the parties denies both the legitimacy of those other aims and the complexity of their interrelationship. These issues rose to the surface when the practical effect of $J L$ Holdings on the work of Australian courts became apparent. This practical effect is the subject of the next section.

\section{APPLICATION OF JL HOLDINGS}

JL Holdings had the potential to have a fairly modest impact. For one thing, the result could have been reached by distinguishing Sali on the facts. For another, the joint judgment is the position of only three High Court judges: not a true majority of the Court. But despite these factors, the case was to have an extensive influence on the way in which Australian judges made procedural decisions. It became the leading authority on the exercise of procedural discretions. Dorne Boniface and 
Michael Legg calculate that the case was applied or followed over 120 times, ${ }^{84}$ often in contexts far removed from the facts of JL Holdings itself:

The decision was given an expansive application well beyond that of the amendment of a pleading, including in relation to the seeking of an adjournment, the vacation of a trial date and other procedural indulgences. ${ }^{85}$

JL Holdings was generally understood as requiring procedural decisions to be based on the dictates of justice as between the parties to the litigation only, without reference to outside considerations' ${ }^{86}$ such as the interests of other litigants or the efficient use of court resources. That is, it narrowed the courts' focus to a purely party-centred understanding of justice. Some commentators welcomed this approach, with one describing the case as 'a refreshing reaffirmation of the purpose and functions of courts':

[T] He High Court has reaffirmed the principle that the ultimate aim of the courts remains the 'attainment of justice' and not simply to function as some efficiency-driven terminator of disputes. ${ }^{87}$

Others cautioned that the High Court's conception of 'justice' as extending only to the immediate parties to the case was too narrow. Justice David Ipp, writing extrajudicially, argued:

[E]fficiency is not in opposition to justice; it is in fact an essential element of a legal system that delivers optimum access to justice to its citizens. Without efficient court procedures justice will be denied to those awaiting their turn; therefore, efficiency cannot be divorced from justice..$^{88}$

84 Dorne Boniface and Michael Legg, 'Cost, Delay and Justice: The High Court of Australia Recognizes the Importance of Case Management in Civil Litigation - Aon Risk Services Australia $v$ Australian National University' (2010) 39 Common Law World Review 157, 165.

85 Ibid, citing as examples two cases in which a trial date was vacated: Nine Films \& Television Pty Ltd v Ninox Television Ltd [2005] FCA 357 and Business in Focus (Aust) Pty Ltd v Begun Property Pty Ltd [2006] FCA 264.

86 Hamilton, above n 59, 265. See also Boniface and Legg, above n 84, 158.

87 Grant T Riethmuller, 'District Court Practice and Procedure' (1997) 17 Queensland Lawyer 151, 153.

88 Justice DA Ipp, 'Opportunities and Limitations for Change in the Australian Adversary System' in Helen Stacy and Michael Lavarch (eds), Beyond the Adversarial System (Federation Press, 1999) 68, 75. 
Seen in this light, by ignoring the public perspective, JL Holdings brings about a situation conducive to injustice. ${ }^{89}$

$J L$ Holdings had a significant effect on the way in which courts managed litigation. ${ }^{90}$ Judges were reluctant to enforce time limits or orders strictly, lest the decision be overturned on appeal by applying $J L$ Holdings. ${ }^{91}$ Finkelstein J observed that $J L$ Holdings had had a 'chilling effect' on the courts' ability to control proceedings. ${ }^{92}$ His Honour described the relaxed attitude towards procedure that had developed as a result:

It is common for parties to do little more than pay lip service to timetables fixed to regulate when steps should be taken to get a case on for trial. ... The view that has taken hold in many quarters is that a party is only required to keep an eye on the timetable and, if it cannot be met, it will be extended. The assumption is that the wronged party will be fully compensated by an award of costs..$^{93}$

[JL Holdings] has, in my view, unfairly hamstrung courts. Almost every day a defaulting party seeks the court's indulgence to extend time, amend documents or obtain some other allowance (often not for the first, second or third time) and successfully relies on JL Holdings to obtain relief. ${ }^{94}$

JL Holdings had an effect, not only on the way in which the courts made decisions, but also, in turn, on the 'culture and mentality' of the legal profession. ${ }^{95}$ Lawyers became confident that late amendments would be allowed, adjournments would be granted, and time limits would be extended. Bryson J explained that litigants therefore had

diminished incentive to do their thinking in due time and to tell the court and their opponents their full and true positions. When forbearance and liberality are extended to a delinquent the burden of inconvenience and lost opportunities for preparation tends to fall heavily and without adequate repair on parties who have not been delinquent. A relative disadvantage is imposed on those who

See Chapter 2 at 15-16 for a discussion of how doing justice between the parties can lead to a denial of justice from the public point of view.

90 See Camille Cameron, 'New Directions for Case Management in Australia' (2010) 29 Civil Justice Quarterly 337, 338-9.

91 Hamilton, above n 59, 265.

92 Black \& Decker (Australasia) Pty Ltd v GMCA Pty Ltd [2007] FCA 1623 [3].

93 Ibid [1].

94 Ibid [3].

95 See Aon (2009) 239 CLR 175, 222-3 (Heydon J), quoting Maronis Holdings Ltd v Nippon Credit Australia Ltd [2000] NSWSC 753, [15] (Bryson J). 
proceed methodically and in due time; their interest in procedural justice should claim at least as much consideration as the interests of the applicant for a late amendment who does not have to look far for the creator of his difficulty. It is even conceivable that a litigant might deliberately pursue a course which will impose disadvantage on an opponent who has to reconsider his ground and change course in the midst of a contest. ${ }^{96}$

Others took a more moderate view of the effect of JL Holdings. Gyles J described it as 'the high water mark of anti case-management philosophy' and said that its effect on case management had been 'exaggerated'. ${ }^{97}$ The case was sometimes distinguished ${ }^{98}$ and efficiency considerations were sometimes used to justify restrictions on the right of parties to argue the case as they saw fit. ${ }^{99}$

Nevertheless, courts and legislatures thought the effects of JL Holdings serious enough to justify the enactment of rules and legislation making explicit the role of efficiency considerations. These provisions are the subject of the next section.

\section{Overarching PurPose Rules: Overturning JL Holdings}

In the last 10 years, almost every Australian jurisdiction has introduced a provision, in either legislation or court rules, setting out the 'overriding' or 'overarching' purpose of procedural rules. ${ }^{100}$ The 'overarching purpose' rules make it clear that doing justice between the parties is not the sole aim of procedure. Section 37M of the Federal Court of Australia Act 1976 (Cth) is an example of a typical 'overarching purpose' provision:

(1) The overarching purpose of the civil practice and procedure provisions is to facilitate the just resolution of disputes:

(a) according to law; and

(b) as quickly, inexpensively and efficiently as possible.

\footnotetext{
96 Maronis Holdings Ltd v Nippon Credit Australia Ltd [2000] NSWSC 753, [15] (Bryson J).

$97 \quad$ Inamed Development Company v Morton Surgical Pty Ltd (2007) 73 IPR 308, 310.

98 See, eg, Dennis v Australian Broadcasting Corporation [2008] NSWCA 37, [27].

99 See, eg, Micallef $v$ ICI Australia Operations Pty Ltd [2001] NSWCA 274 (dismissal of an action for want of prosecution following persistent failure by the plaintiff to comply with directions).

$100 \quad$ Federal Court of Australia Act 1976 (Cth) s 37M (commenced on 1 January 2010); Civil Procedure Act 2005 (NSW) ss 56-8; Supreme Court Civil Rules 2006 (SA) r 3; Court Procedures Rules 2006 (ACT) r 21; Uniform Civil Procedure Rules 1999 (Qld) r 5; Supreme Court (General Civil Procedure) Rules 2005 (Vic) r 1.14 and Civil Procedure Act 2010 (Vic) ss 7-9; Supreme Court Rules (NT) r 1.10. For a discussion of these rules, including some examples of their application, see Michael Legg, Case Management and Complex Civil Litigation (Federation Press, 2011) 23-43. The relevant provisions are described as either the 'overarching purpose', 'overriding objective', 'overriding obligation' or simply 'objects' of civil procedure rules. In this thesis, for convenience, I use the term 'overarching purpose' when speaking of these provisions generally.
} 
(2) Without limiting the generality of subsection (1), the overarching purpose includes the following objectives:

(a) the just determination of all proceedings before the Court;

(b) the efficient use of the judicial and administrative resources available for the purposes of the Court;

(c) the efficient disposal of the Court's overall caseload;

(d) the disposal of all proceedings in a timely manner;

(e) the resolution of disputes at a cost that is proportionate to the importance and complexity of the matters in dispute.

This provision invokes all four of the aims of civil procedure identified in Chapter 2 of this thesis: justice between the parties; ${ }^{101}$ public justice; ${ }^{102}$ efficiency for the parties; ${ }^{103}$ and efficiency for the public. ${ }^{104}$ Section $37 \mathrm{M}(3)$ provides that all procedural rules

must be interpreted and applied, and any power conferred or duty imposed by them ... must be exercised or carried out, in the way that best promotes the overarching purpose.

Section $37 \mathrm{~N}$ places a duty on parties and their legal representatives to conduct proceedings in a manner consistent with the overarching purpose.

One impetus for the introduction of overarching purpose provisions was a desire to 'overturn the reasoning' in JL Holdings that justice was paramount over efficiency. ${ }^{105}$ The explanatory memorandum to legislation introducing s 37M explained:

Particular concern has been expressed about the Court's powers to actively case manage following the High Court's decision in [JL Holdings]. ... This decision has led to a restrictive interpretation by the courts of what is in the interests of justice, and has made judges more cautious about considering the need to effectively and efficiently manage the court's overall workload. ${ }^{106}$

\footnotetext{
$101 \quad$ Section $37 \mathrm{M}(1)(\mathrm{a}),(2)(\mathrm{b})$.

102 Section $37 \mathrm{M}(2)(\mathrm{a})$ ('the just determination of all proceedings before the Court') and (d).

103 Section $37 \mathrm{M}(1)(\mathrm{b}),(2)(\mathrm{e})$.

$104 \quad$ Section $37 \mathrm{M}(1)(\mathrm{b})$ and $(\mathrm{c})$.

105 See Aon (2009) 239 CLR 175, 213; Cameron, above n 90, 343-7; Legg, above n 100, 43, citing Second Reading Speech to the Civil Procedure Bill 2005 and Uniform Civil Procedure Rules 2005 (NSW), New South Wales, Legislative Assembly, Parliamentary Debates (Hansard), 6 April 2005, 15115 and Explanatory Memorandum, Access to Justice (Civil Litigation Reforms) Amendment Bill 2009, 9. (Cth), 3.
} 
The inspiration for overarching purpose provisions in Australian court rules came from the US and UK. An early prototype of 'overarching purpose' rules was $\mathrm{r} 1$ of the Federal Rules of Civil Procedure 1937 (US), which provided that the rules were to be 'construed and administered to secure the just, speedy, and inexpensive determination of every action and proceeding.' A more modern blueprint for the Australian rules was r 1.1 of the Civil Procedure Rules 1998 (UK), a result of the landmark Woolf reforms of civil procedure. ${ }^{107}$ Rule 1.1 provided that the Civil Procedure Rules were 'a new procedural code with the overriding objective of enabling the court to deal with cases justly.' ${ }^{108}$ This did not mean, however, that justice between the parties, was the only goal. On the contrary, r 1.1 provides that 'Dealing with a case justly' includes a range of factors, including

(a) ensuring that the parties are on an equal footing;

(b) saving expense;

(c) dealing with the case in ways which are proportionate -

(i) to the amount of money involved;

(ii) to the importance of the case;

(iii) to the complexity of the issues; and

(iv) to the financial position of each party;

(d) ensuring that it is dealt with expeditiously and fairly; and

(e) allotting to it an appropriate share of the court's resources, while taking into account the need to allot resources to other cases. ${ }^{109}$

Once again, this rule incorporates considerations of efficiency, both for the parties and the public. It does so, however, in the name of dealing with cases 'justly'.

The overarching purpose rules make it clear that justice between the parties is not the only aim of civil procedure. They legitimise the application of case management principles. But having opened up the range of objectives to which procedure may be directed, overarching purpose provisions raise some of the very questions this thesis explores. What happens when the different objectives come into conflict with one another? The overarching purpose rules bear some resemblance to Zuckerman's

\footnotetext{
107 Lord Woolf, Access to Justice: Interim Report to the Lord Chancellor on the Civil Justice System in England and Wales (1995); Lord Woolf, Access to Justice: Final Report to the Lord Chancellor on the Civil Justice System in England and Wales (1996).

108 Civil Procedure Rules 1998 (UK) r 1.1(1) (emphasis added).

$109 \quad$ Ibid $r$ 1.1(2).
} 
theory, discussed in Chapter 5,110 that justice involves dimensions of cost, time and accuracy. Like Zuckerman's work, the overarching purpose provisions provide little guidance on how to prioritise these dimensions in cases of conflict.

Despite these conceptual difficulties, the overarching purpose provisions have played a significant part in the evolution of Australian civil procedure. Writing extrajudicially, Justice Ronald Sackville has said the overarching purpose rules symbolise '[ $t$ ] he triumph of case management in Australia'. ${ }^{111}$ In the next section of this chapter, I examine the way in which the combination of an overarching purpose provision and concern about the effect of JL Holdings, led to the High Court reconsidering its position on case management.

\section{AON: ${ }^{112}$ CASE MANAGEMENT RISES AgAIN}

Contested interlocutory matters rarely go as far as the High Court. It is not surprising, then, that it was 12 years before the High Court had the opportunity to reconsider JL Holdings. In the meantime, as we have seen, dissatisfaction about the effect of $J L$ Holdings had developed. Overarching purpose rules had been introduced in order to bring efficiency considerations to the fore. These rules had, perhaps, modified the principles in JL Holdings. ${ }^{113}$ In addition, there was doubt about whether judges in trial courts were interpreting JL Holdings correctly. ${ }^{114}$ In Aon, the pendulum swung back towards efficiency considerations.

Aon, like JL Holdings, involved an application to amend pleadings. The Australian National University ('ANU') sued three insurers in the ACT Supreme Court for indemnity for damage to ANU property caused by the 2003 Canberra bushfires. ANU also sued its insurance broker, Aon Risk Services Australia Ltd ('Aon'), for failing to renew insurance over some of the property. ${ }^{115}$ On the third day of a four week trial, the matter settled as between ANU and the insurers. ANU then applied to amend its statement of claim to add a new claim against Aon on the basis that, under a separate contract, Aon had been obliged to ascertain and declare the correct

\footnotetext{
$110 \quad$ At $65-8$.

111 Acting Justice Ronald Sackville, Foreword to Michael Legg, Case Management and Complex Civil Litigation (Federation Press, 2011), v.

$112 \quad$ (2009) 239 CLR 175.

113 See Dennis v Australian Broadcasting Corporation [2008] NSWCA 37, [28]-[29]; New South Wales v Mulcahy [2006] NSWCA 303, [25]-[29].

114 In argument on special leave, Gummow J said that 'If [JL Holdings] is being misread, perhaps something has to be done about it': Aon Risk Services Australia Ltd v Australian National University [2009] HCATrans 26, 2.

115 The case against the broker proceeded on the basis that, contrary to ANU's primary case, the insurers were not liable.
} 
value of the property to the insurers and to provide certain advice. ANU's explanation for the lateness of the amendment was that the significance, for the insurers, of the declared value of the property did not become apparent until mediation (on the first day of the trial).

The application to amend was heard on 27 November 2006 but it was almost 11 months until the trial judge handed down his decision in the matter. ${ }^{116}$ The trial judge granted permission to amend and ordered ANU to pay Aon's costs of the amendments. The most significant factor was that the amendment raised 'real triable issues' ${ }^{117}$ The ACT Court of Appeal dismissed Aon's appeal. ${ }^{118}$

The High Court unanimously overturned the Court of Appeal's decision and dismissed the application for leave to amend. Gummow, Hayne, Crennan, Kiefel and Bell JJ wrote a joint judgment, with French CJ and Heydon J delivering separate concurring judgments.

All of the judges accepted that the discretion to amend pleadings ${ }^{119}$ was guided by the overarching purpose provision in r 21 of the Civil Procedures Rules 2006 (ACT). Rule 21 provided that the purpose of the rules was 'to facilitate the just resolution of the real issues in civil proceedings with minimum delay and expense' ${ }^{120}$ Hence, the rules were to be applied 'with the objective of achieving' not merely 'the just resolution of the real issues' ${ }^{121}$ but also 'the timely disposal of the proceedings, and all other proceedings in the court, at a cost affordable by the respective parties.' ${ }^{122}$

The High Court considered that $\mathrm{r} 21$ formally recognised the role that case management now plays in procedural decision-making. The evolution of case management principles meant that justice between the parties was no longer the

116 Aon (2009) 239 CLR 175, 197. On the topic of the trial judge's delay, Heydon J commented: A party which has a duty to assist the court in achieving certain objectives fails to do so. A court which has a duty to achieve those objectives does not achieve them. The torpid languor of one hand washes the drowsy procrastination of the other. (2009) 239 CLR 175, 229.

117 Australian National University v Chubb Insurance Co of Australia Ltd [2007] ACTSC 82, [43].

118 Aon Risk Services Australia Ltd v Australian National University (2008) 227 FLR 388.

119 In Court Procedures Rules 2006 (ACT) r 502. One of the issues on appeal was whether ANU relied on $\mathrm{r} 502$ or on $\mathrm{r} 501$, which provided that amendments 'must' be made if necessary in order to decide 'the real issues in the proceeding'. The High Court held that $\mathrm{r} 501$ was inapplicable as the amendment raised a new issue. Therefore $\mathrm{r} 502$ was the only source of power to make the amendment. See Aon (2009) 239 CLR 175, 208-10, 219-21.

$120 \quad$ Rule 21(1).

$121 \quad$ Rule 21(2)(a).

122 Rule 21(2)(b) (emphasis added). 
only consideration in the exercise of procedural discretions. French CJ explained that:

the adversarial system has been qualified by changing practices in the courts directed to the reduction of costs and delay and the realisation that the courts are concerned not only with justice between the parties, which remains their priority, but also with the public interest in the proper and efficient use of public resources. ${ }^{123}$

Similarly, the authors of the joint judgment said case management was 'now an accepted aspect of the system of civil justice administered by courts in Australia.' ${ }^{124}$ Their Honours explained that the principles of case management, both under $\mathrm{r} 21$ and at common law, involved broadening the considerations judges must take into account:

Rule 21(1)(b) indicates that the rules concerning civil litigation no longer are to be considered as directed only to the resolution of the dispute between the parties to a proceeding. The achievement of a just but timely and cost-effective resolution of a dispute has an effect upon the court and upon other litigants. ${ }^{125}$

Applying these principles to the facts, the Court held the amendment ought to have been denied. The application came very late; if granted, it would delay the continuation of the trial and require Aon to do a substantial amount of preparation to defend the new claim; and there was no satisfactory explanation for the failure to make the claim earlier. ${ }^{126}$ Because the primary judge had placed too much weight on the fact that the amendment raised an arguable new issue, and too little on the other objectives of $\mathrm{r} 21$, the exercise of the discretion had miscarried. ${ }^{127}$

The Court's approach in Aon has two implications for the examination, in this thesis, of the relationship between justice and efficiency. First, Aon confirms a recurring theme of the thesis: justice between the parties is no longer the only aim of civil procedure. Gummow, Hayne, Crennan, Kiefel and Bell JJ took into account the aim of public justice. Their Honours referred with approval to comments by Toohey and Gaudron JJ in Sali, and by Waller LJ in the UK Court of Appeal, to the effect that courts must be concerned with doing justice to all litigants, not just the parties to the immediate case. ${ }^{128}$ This, their Honours said, was

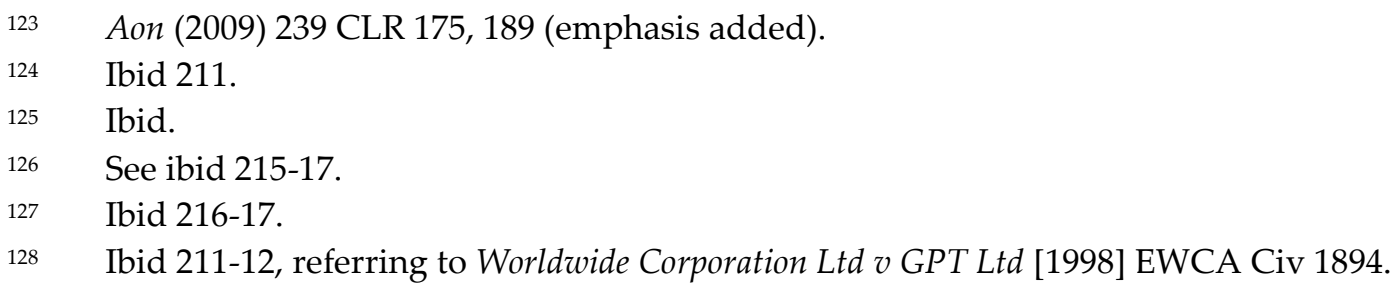


a fundamental principle of case management. What may be just, when amendment is sought, requires account to be taken of other litigants, not just the parties to the case. ${ }^{129}$

Public efficiency was also relevant in Aon, at least for French CJ. His Honour said:

the time of the court is a publicly funded resource. Inefficiencies in the use of that resource, arising from the vacation or adjournment of trials, are to be taken into account. ${ }^{130}$

This remark recognises the public interest in courts, like any other publicly funded institution, using taxpayer dollars responsibly. As I argued in Chapter 2,131 this aim is distinct from the aim of doing justice.

The second important point in Aon, for the purposes of this thesis, is that, as it had in Sali, the Court in Aon explained that case management involves an expanded understanding of justice, rather than a departure from the objective of doing justice. This is most clearly illustrated in the following passage from the judgment of Gummow, Hayne, Crennan, Kiefel and Bell JJ:

Of course, a just resolution of proceedings remains the paramount purpose of $r$ 21; but what is a 'just resolution' is to be understood in light of the purposes and objectives [of $\mathrm{r}$ 21]. Speed and efficiency, in the sense of minimum delay and expense, are seen as essential to a just resolution of proceedings. This should not detract from a proper opportunity being given to the parties to plead their case, but it suggests that limits may be placed upon re-pleading, when delay and cost are taken into account. ${ }^{132}$

As I have argued previously, ${ }^{133}$ this approach is problematic. Describing efficiency measures as reflecting a wider view of justice may be logical when discussing access to justice for other litigants. But they may also mask the fact that what is being described is a different set of objectives of civil procedure: the efficient use of public and party resources, rather than justice for the parties or the public.

French CJ was cautious to emphasise the role of justice in procedural decisionmaking. He thought it a 'truism' that "“case management principles" should not supplant the objective of doing justice between the parties according to law.' ${ }^{134}$ This

\footnotetext{
$129 \quad$ Ibid 212.

$130 \quad$ Ibid 182. French CJ made further remarks about the use of public resources at 189, 191 and 192.

$131 \quad$ At 19.

$132 \quad$ Aon (2009) 239 CLR 175, 213.

133 At 19 in Ch 2 and above at 112 in relation to Kirby J in JL Holdings.

$134 \quad$ Aon (2009) 239 CLR 175, 192.
} 
however did not mean that other considerations could be disregarded. In fact, in this case those other considerations proved to be determinative; arguably, they did supplant the objective of doing justice between the parties.

What did the High Court in Aon make of JL Holdings? The cases were factually distinguishable: in JL Holdings, the application was made six months prior to trial; there was a reasonable explanation for its lateness; and the issue was raised on documents which were already to be considered as part of the trial. ${ }^{135}$ Further, the decision in Aon relied in part on application of an overarching purpose provision, which (like the equivalent provisions in other jurisdictions) had been introduced as a reaction to JL Holdings. Heydon J said that

at least in jurisdictions having rules similar to $\mathrm{rr} 21$ and 502, [JL Holdings] has ceased to be of authority. It is necessary to apply the Rules without any preconceptions derived from what was said in that case. ${ }^{136}$

In other words, r 21 and its equivalents had effectively overridden JL Holdings. The other judges went further still, holding that the reasoning in JL Holdings was wrong, and inconsistent with the earlier authority of Sali. Gummow, Hayne, Crennan, Kiefel and Bell JJ said that Sali, in acknowledging the relevance of disruption to court lists and the interests of other litigants,

reflected a proper understanding of case management. The statements in JL Holdings do not reflect such an understanding and are not consistent with what was said in Sali $v$ SPC. To say that case management principles should only be applied 'in extreme circumstances' to refuse an amendment implies that considerations such as delay and costs can never be as important as the raising of an arguable case; and it denies the wider effects of delay upon others. ${ }^{137}$

Contrary to JL Holdings, then, other considerations could carry as much weight as justice between the parties. Their Honours concluded that JL Holdings should no longer be considered good authority:

Statements in JL Holdings which suggest only a limited application for case management do not rest upon a principle which has been carefully worked out in a significant succession of cases. On the contrary, the statements are not consonant with this Court's earlier recognition of the effects of delay, not only 
upon the parties to the proceedings in question, but upon the court and other litigants. Such statements should not be applied in the future. ${ }^{138}$

French CJ reached a similar conclusion:

[T]o the extent that statements about the exercise of the discretion to amend pleadings in [JL Holdings] suggest that case management considerations and questions of proper use of court resources are to be discounted or given little weight, it should not be regarded as authoritative. ${ }^{139}$

Not only did the Court effectively overrule JL Holdings, ${ }^{140}$ they also called into question several well accepted principles of civil procedure. One of these was the oft-cited judgment of Bowen LJ in Cropper $v$ Smith. ${ }^{141}$ This judgment had been interpreted as requiring a permissive approach to pleadings amendments and other interlocutory applications, on the basis that litigants have a right to raise arguable issues. In Aon, the Court suggested that, rather than being an authoritative statement of the general approach to procedural decisions, Bowen LJ's statement actually had quite a limited reach when understood in the context of the facts of Cropper $v$ Smith. ${ }^{142}$ Properly understood, that case did not stand for the proposition that litigants had a 'right' to late amendments. Rather, amendment was a matter for the judge's discretion in each case, taking into account all relevant matters including efficiency considerations. ${ }^{143}$

Also abandoned was Bowen LJ's faith in the power of costs orders to overcome prejudice. ${ }^{144}$ The non-financial strain that litigation places upon parties means that delay could cause prejudice not measurable in dollar terms. ${ }^{145}$ While natural persons might feel more strain, corporate litigants could suffer significant non-compensable prejudice because of the effect of ongoing litigation on their ability to plan their financial affairs. ${ }^{146}$

\footnotetext{
$138 \quad$ Ibid 217 (citations omitted).

139 Ibid 182. See also 191.

140 While the Court did not expressly state that JL Holdings was overruled, that appears to be the effect of the decision. See Cameron, above n 59, 348-9.

$141 \quad$ (1884) $26 \mathrm{Ch}$ D 700, discussed above at 85.

142 See Aon (2009) 239 CLR 175, 187-8, 212, 206-7. Cropper $v$ Smith involved an application by one defendant to raise a defence which had already been pleaded by the co-defendant. Therefore the amendment raised a matter which was already in issue in the proceedings. No additional work or delay would result.

143 Aon (2009) 239 CLR 175, 212-13.

144 See Ibid 187-8, 213-14.

145 Ibid 213-14

146 Ibid 214; see also 223-4 (Heydon J).
} 
Finally, the Court in Aon acknowledged that there has been a move away from the long-accepted principle of party control of proceedings. Gummow, Hayne, Crennan, Kiefel and Bell JJ said:

In the past it has been left largely to the parties to prepare for trial and to seek the court's assistance as required. Those times are long gone. The allocation of power, between litigants and the courts arises from tradition and from principle and policy. It is recognised by the courts that the resolution of disputes serves the public as a whole, not merely the parties to the proceedings. ${ }^{147}$

Once the Court had adopted a concept of justice that encompassed the interests of the public as well as the parties, there had to be a shift in power from the parties to the court.

Aon marked 'a profound departure' from the JL Holdings position on the role of case management. ${ }^{148}$ The High Court acknowledged case management has changed the landscape of procedural decision-making. This change is partly a consequence of the application of new 'overarching purpose' rules. But it also reflects wider changes to the adversarial system and the context in which litigation is contested today. So significant were these changes that the Court in Aon accepted that some of the most well established principles of procedural law - party control and a narrow focus on justice between the parties - were no longer tenable.

\section{EXPENSE REDUCTION: ${ }^{149}$ AON REAFFIRMED}

The High Court most recently considered the role of case management in its November 2013 decision in Expense Reduction. In a joint judgment, French CJ, Kiefel, Bell, Gageler and Keane JJ confirmed the approach adopted in Aon.

In the course of a large electronic discovery process, the defendants in an action in the Supreme Court of New South Wales inadvertently disclosed documents over which they had intended to claim legal professional privilege. When the plaintiffs refused to return the documents, the defendants applied for interlocutory orders requiring the return of the documents. This dispute spawned a three-day primary hearing, followed by appeals to the Court of Appeal and, ultimately, the High Court.

The High Court concluded that '[p]roceedings of this kind and length concerning a tangential issue should have been averted.' ${ }^{150}$ The primary judge should have, in the

\footnotetext{
$147 \quad$ Ibid 217. See also 188-9 (French CJ).

148 Ronald Sackville, 'Mega-Lit: Tangible Consequences Flow From Complex Case Management' (2010) Law Society Journal 47, 48.

149 (2013) 250 CLR 303.
} 
High Court's view, permitted the defendants to amend their list of documents and ordered the plaintiffs to return the documents as soon as the inadvertent disclosure came to light. The Court reached this conclusion by reference to the 'overriding purpose' provision in the Civil Procedure Act 2005 (NSW), ${ }^{151}$ and the reasoning in Aon.

Importantly, the Court endorsed Aon's focus on the objectives of civil procedure beyond the interests of the parties:

In $[A o n]$, it was pointed out that case management is an accepted aspect of the system of civil justice administered by the courts in Australia. It had been recognised some time ago by courts in the common law world that a different approach was required to tackle the problems of delay and cost in the litigation process. Speed and efficiency, in the sense of minimum delay and expense, are essential to a just resolution of proceedings. The achievement of a just but timely and cost-effective resolution of a dispute has effects not only upon the parties to the dispute but upon the court and other litigants. The decision in Aon ... confirmed as correct an approach to interlocutory proceedings which has regard to the wider objects of the administration of justice. ${ }^{152}$

Here, by considering the effect of this litigation on 'the court and other litigants' the High Court is invoking the objective of public justice and, perhaps, public efficiency.

The Court made another point emphasised throughout the past two chapters: the modern approach to case management shifts responsibility for control of proceedings from the parties to the court. Their Honours explained that '[p]arties continue to have the right to bring, pursue and defend proceedings in the court, but the conduct of those proceedings is firmly in the hands of the court.' 153

The Court reviewed the overriding purpose provisions of the Civil Procedure Act 2005 (NSW). Their Honours noted that, while ss 56 and 57 set up an overriding purpose, which incorporates efficiency objectives, s 58(1) requires the court, when making procedural decisions, to 'act in accordance with the dictates of justice'. Section 58(2) provides that, in deciding what the dictates of justice are, the court must have regard to ss 56 and 57 . This statutory scheme appears to place the efficiency objectives in the overriding purpose within the concept of 'the dictates of justice'. In Expense Reduction, the authors of the joint judgment concluded that the overriding purpose

\footnotetext{
$150 \quad$ Ibid 309 [7].

151 Section 56(1) of the Act provides that the purpose of the Act, and the Rules of Court, is 'to facilitate the just, quick and cheap resolution of the real issues in the dispute'.

152 Expense Reduction (2013) 250 CLR 303, 321 [51] (citations omitted).

153 Ibid 323 [56] (emphasis added).
} 
in the Civil Procedure Act (and, presumably, similar provisions in other jurisdictions) 'may require a more robust and proactive approach on the part of the courts. Unduly technical and costly disputes about non-essential issues are clearly to be avoided.' ${ }^{154}$ This endorsement of active - even aggressive - case management is qualified by what follows:

[T] he powers of the court are not at large and are not to be exercised according to a judge's individualistic idea of what is fair in a given circumstance. Rather, the dictates of justice referred to in s 58 require that in determining what directions or orders to make in the conduct of the proceedings, regard is to be had in the first place to how the overriding purpose of the [Civil Procedure Act] can be furthered ... The focus is upon facilitating a just, quick and cheap resolution of the real issues in the proceedings, although not at all costs. The terms of the [Civil Procedure Act] assume that its purpose, to a large extent, will coincide with the dictates of justice. ${ }^{155}$

This interpretation of the overriding purpose provisions begs the question of what happens when the multiple objectives within the overriding purpose do not coincide. What is a judge to do when 'quick and cheap' is not the same as 'just'? Can a judge rely on the rather circular reasoning that a quick and cheap decision furthers the overriding purpose and is, therefore, consistent with the dictates of justice? The decision in Expense Reduction, while confirming the place of 'robust' case management in contemporary civil procedure, sheds little light on these dilemmas.

\section{CONCLUSION}

The developments analysed in the last two chapters demonstrate a shift in the priorities of civil procedure in Australia over the last 30 years. The courts have moved away from an almost exclusive focus on doing justice between the parties in each case. Courts now recognise that litigation is not just a matter for the immediate parties; it affects other litigants and would-be litigants whose access to justice is at stake. To this end, courts have embraced a public perspective on justice. Furthermore, a number of statements in the cases indicate that public efficiency has also become relevant to procedural decision-making. As taxpayer-funded institutions providing a public good, courts should deploy their resources efficiently. Once these broader aims of procedure are accepted, the traditional adversarial approach, based on party control, is no longer acceptable. Case management is the practical manifestation of this shift in thinking about the aims of civil procedure. The principles of case management move control of procedure from the parties to

\footnotetext{
$154 \quad$ Ibid 323 [57].

155 Ibid (emphasis added).
} 
the court, and in doing so enable the court to take into account matters beyond the interests of the parties.

This shift in thinking about civil procedure has not been painless. The developments examined in this chapter demonstrate the tension between some of the ideals of the adversarial system - the 'inactive, passive and non-interventionist'156 judge determining the rights of the parties, no matter what the cost - and the reality of courts struggling to cope with growing caseloads and recalcitrant litigants. In Sali the High Court accepted that from a practical point of view, a narrow focus on doing justice between the parties was no longer appropriate; case management had a significant role to play. The Court's temporary retreat from this position in $J L$ Holdings reflected a desire to preserve the role of the court as an institution which exists to do justice in individual cases. Aon and Expense Reduction represent an attempt to conceptualise the role of the court, and the notion of justice, in a more nuanced way. In both cases the Court adopted a view of 'justice' that included considerations of public justice and public efficiency. The current state of Australian law, then, strikes a balance between the aims of civil procedure that I have identified. Justice between the parties remains an important aim - in many cases, the most important. But it is not unassailable by competing objectives.

Chapter 5 of this thesis surveyed some of the leading theories on civil procedure. To what extent does the reality of civil procedure in Australia today reflect these theoretical perspectives? The current Australian situation is perhaps closest to Adrian Zuckerman's 'three-dimensional' view of justice. ${ }^{157}$ Courts are left to find the optimal compromise between multiple objectives, but there is a substantial margin for choice about just how to find this compromise. In addition, the constitutional protection of due process quite strongly with Summers' 'process values' theory. Characteristics such as impartiality, fairness and open justice are constitutionally protected, not because they produce good outcomes in particular cases, but because they are of intrinsic value within our system of justice.

The economic analysis advocated by Posner appears incompatible with the constitutional constraints on court procedure. ${ }^{158}$ This is because a pure cost-benefit analysis would not take into account the presence of constitutionally protected elements of procedure which are required regardless of cost. The economic approach could, however, be useful in evaluating the benefits of procedures over

\footnotetext{
156 Sir Jack IH Jacob, The Fabric of English Civil Justice (Stevens \& Sons, 1987), 9.

157 Discussed in Chapter 5 at 65-8.

158 Discussed in Section II of this chapter.
} 
and above the constitutional minimum. The constitutional 'due process principle' bears some resemblance to Dworkin's theory that there is a minimum level of procedure which simply cannot be sacrificed in the name of efficiency. Unlike Dworkin's theory, however, the guaranteed minimum level of due process in Australia is not set by reference to the moral harm caused to individuals by the denial of legal rights. The due process principle is based on the maintenance of the institutional characteristics of courts, rather than on the protection of individuals' rights. ${ }^{159}$

The story of justice, efficiency and case management in Australian civil procedure is, of course, not at an end. The last few years have seen significant reforms of procedure in Victoria ${ }^{160}$ and in the federal jurisdiction. ${ }^{161}$ Increasing the efficiency of court processes and improving access to justice remains a priority of courts and governments throughout Australia. ${ }^{162}$

This chapter completes Part II of the thesis. This thesis examines the relationship between justice and efficiency in mega-litigation. Part II has explored ways in which scholars, judges and legislators have approached this relationship in civil procedure generally (as opposed to mega-litigation specifically). In this Part, we have encountered some of the 'deep and philosophical puzzles'163 surrounding the multiple, and sometimes contradictory, aims of civil procedure. Is it acceptable to sacrifice justice for the sake of efficiency? If so, when? How can justice be measured against efficiency? What happens when doing justice in one case means denying justice to other litigants? These puzzles will reappear in Part III of the thesis; this time in the specific, practical context of mega-litigation. Part II has provided the theoretical and doctrinal backdrop against which the drama of justice and efficiency in mega-litigation is played out.

159 For a discussion of the themes of institutional integrity and individual rights in Chapter III jurisprudence, see Rachael Gray, 'Legal "Truth", Judicial Method and Chapter III' (Paper presented to the Australian Association of Constitutional Law, Adelaide, 13 April 2011).

160 See Civil Procedure Amendment Act 2012 (Vic).

161 See Federal Court Rules 2011 (Cth).

162 See, eg, Productivity Commission, Access to Justice Arrangements: Draft Report (April 2014).

163 Ronald Dworkin, A Matter of Principle (Clarendon Press, 1986), 72. 


\section{PART III:}

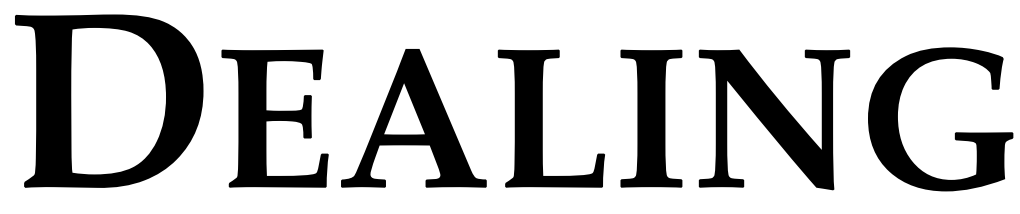

\section{WITH MEGA-}

LITIGATION 


\section{Chapter 8: The Mega-Litigation Judge}

\section{INTRODUCTION}

To dare; that is the price of progress. ${ }^{1}$

Part III of the thesis commences with this chapter. Part I explained why megalitigation is a problem for the contemporary Australian justice system. In brief, mega-litigation places a burden on court resources, and has adverse consequences for access to justice. There is, therefore, a powerful argument that the management of mega-litigation should not focus solely on justice between the parties: public justice and public efficiency cannot be ignored. Part II of this thesis explored some theoretical and practical approaches to the relationship between public and partybased concepts of justice and efficiency in civil procedure. Part III brings together the ideas developed in Parts I and II, by examining the way in which Australian judges reconcile the various aims of civil procedure when dealing with megalitigation. This part of the thesis draws heavily on the original qualitative interview data collected for this project.

Part III consists of three substantive chapters, followed by a concluding chapter. The present chapter discusses the general principles that inform judges' approach to mega-litigation. This, in itself, will provide insights into the way in which judges reconcile the demands of justice and efficiency. Chapter 9 identifies the way these principles are put into action, providing an overview of the procedural techniques that judges use in mega-litigation. Building on this material, and on the analysis in Parts I and II of the thesis, Chapter 10 squarely confronts the issue of how judges in mega-litigation reconcile the demands of justice and efficiency.

In this chapter I examine the approaches and attitudes that judges bring to megalitigation. The qualitative research method employed in this thesis allows for the development of a 'thick description' ${ }^{2}$ of the mega-litigation judge. A 'thick description'

does more than record what a person is doing. It goes beyond mere fact and surface appearances. It present detail, context, emotion, and the webs of social relationship that join persons to one another. ${ }^{3}$

Victor Hugo, Les Miserables (1862), Vol III, Book 1, Ch XI.

Clifford Geertz, 'Thick Description: Toward an Interpretive Theory of Culture' in Clifford Geertz (ed), The Interpretation of Cultures (Basic Books, 1973) 3.

Norman K Denzin, Interpretive Interactionism (Sage, 1989) 83. 
Developing a 'thick description' is helpful, in this thesis, because of the ontological assumption underlying my research: that judges' perceptions of their role are influenced by their individual experiences and personality. It is also helpful because of my belief that the task of managing mega-litigation is not captured fully in published orders and judgments. In this thesis, a 'thick description' goes beyond a superficial description of the actions that judges perform when presiding over megalitigation. ${ }^{4}$ The next three chapters explore the context and motivation that inform these actions.

This chapter is divided into two substantive sections. In section II I identify four characteristics that are consistently displayed in judges' approach to mega-litigation. The mega-litigation judge is a highly active participant in the preparation and presentation of the case; is creative in finding new ways of dealing with megalitigation; is flexible in their approach to procedure; and places a high priority on fairness. The identification of these characteristics raises a further question: to what extent does the management of mega-litigation depends on characteristics personal to each judge? In section III of the chapter I explore the way in which the personality and experience of judges affects their approach to mega-litigation. I conclude that these personal factors make a significant - and inescapable - contribution to the way in which judges deal with mega-litigation.

Throughout this chapter, I situate the characteristics of the mega-litigation judge within the broader trends in civil procedure explored in Chapters 6 and 7 . It will become apparent that mega-litigation judges tend to be daring and non-traditional. Their characteristics are consistent with the movement towards active case management, and away from party control, explored in Chapters 6 and 7. Megalitigation judges seem to be testing the boundaries of this shift. Examination of the role of mega-litigation judges reveals that these judges believe that civil procedure must serve the ends of public justice and public efficiency as well as justice and efficiency for the parties. It follows that mega-litigation judges consistently reject the premise of party control, and take upon themselves responsibility for the progress of litigation.

\section{CHARACTERISTICS OF THE MEGA-LITIGATION JUDGE}

The qualitative interview data reveals that interview participants, in their role as judges in mega-litigation, tend to share certain characteristics. From this data, it is

See Joseph G Ponterotto, 'Brief Note on the Origins, Evolution, and Meaning of the Qualitative Research Concept “Thick Description”' (2006) 11 The Qualitative Report 538. 
possible to create a portrait of what I will refer to, in the rest of this thesis, as 'the mega-litigation judge'. Interview participants were, to a degree, self-selecting: individuals willing to participate in this project were likely to be concerned about justice and efficiency in mega-litigation, and to believe that they were able to contribute useful insights on the issue. ${ }^{5}$ Therefore, the mega-litigation judge portrayed in this thesis may not represent every judge who has presided over megalitigation. It is, however, the most comprehensive account of the mega-litigation judge in Australia to date.

The mega-litigation judge tends to be active, creative, flexible and fair in their approach to procedure in mega-litigation. These characteristics are, as we will see, interrelated. The mega-litigation judge's active case management style enables them to tailor flexible and creative procedures. Fairness tempers the other characteristics: active involvement must not translate into a loss of impartiality; novel procedures must still allow the parties a fair hearing. In this section I discuss each of these characteristics in turn.

\section{A Active}

Chapters 6 and 7 of this thesis charted the evolution of the Anglo-Australian approach to civil procedure over the last century and a half. The rise of case management has been the dominant trend over the last 30 years. Case management is a staple of modern judicial practice and is particularly important in megalitigation. As early as 1951, the Judicial Conference of the United States' Prettyman Report (the first major report on the problem of complex litigation) recognized that:

the efficient conduct of [a complex case] depends in large part upon a skilful and complete pre-trial organization of the proposed evidence, the expected witnesses, and the trial personnel....

The person who must insure that a case of this nature is thoroughly prepared prior to the trial is the trial judge himself. ... The actual work must be done by counsel. But one of the tasks of the trial judge in a case of this sort is to make certain, prior to setting the case for trial, that counsel are completely prepared and have efficiently organized their material. This is a task of inquiry and negotiations on the part of the judge and may require considerable patience and persistence. $^{6}$

See the Appendix for an explanation of the methodology used to select, and invite, participants. Judicial Conference of the United States, Procedure in Anti-Trust and Other Protracted Cases (1951), reprinted in (1951) 13 Federal Rules Decisions 41, 65 (emphasis added). 
Contemporary US and UK publications reiterate the centrality of case management as a means of dealing with complex litigation. The US Federal Judicial Center's Manual for Complex Litigation takes the position that '[f]air and efficient resolution of complex litigation requires at least that ... the court exercise early and effective supervision (and, where necessary, control)'. ${ }^{7}$ The UK Commercial Court Long Trials Working Party recommended that a Commercial Court judge must remain 'in charge of all preparatory procedures' in a complex matter and, '[f]urthermore, the judge must be able to keep firm control over all the procedure before trial and during the trial. ${ }^{\prime}$ In Australia, Ronald Sackville has argued that

[v]igorous pre-trial judicial management of mega-litigation ... is likely to have a moderating effect on the excesses of the warring parties, if only because even the most resolute of parties or counsel usually cannot afford to ignore entirely the express wishes of the judge. ${ }^{9}$

The interview data supported the view that active case management is central to managing mega-litigation. Interview participants described their approach to management of mega-litigation in the following terms:

I think judges have to be reasonably interventionist in managing these cases rather than just allowing the litigation to be run entirely by what the parties want to do. ${ }^{10}$

I'm proactive ... I think I would be regarded as interventionist. ${ }^{11}$

I probably was [an interventionist judge], yes, I probably was. Not to excess, but within what I considered was the spirit under which the Federal Court had been formed, which was ... to confine procedural issues ... and have speed and efficiency as the hallmarks of the Court. ${ }^{12}$

I start from the proposition that cases in that category [mega-litigation] require pretty aggressive case management if they're not to get out of hand, if they're to stay within manageable proportions. ${ }^{13}$

I think the courts have got to take control again and to say to people 'well, this is how we're going to deal with this'. ${ }^{14}$

Federal Judicial Center, Manual for Complex Litigation, Fourth (2004), 7.

Judiciary of England and Wales, Report and Recommendations of the Commercial Court Long Trials Working Party (December 2007), [28] 15.

$9 \quad$ Acting Justice Ronald Sackville, 'Mega-Litigation: Towards a New Approach' (2008) 8 The Judicial Review 89, 101.

10 Interview with Justice David Bleby (Adelaide, 16 February 2012).

11 Interview with Participant D.

12 Interview with the Honourable Malcolm Lee QC (Fremantle, 6 March 2013).

13 Interview with Chief Justice Wayne Martin (Perth, 6 March 2013). 
I was doing what I think all judges should do. That requires more than sitting in court and listening to the parties. ${ }^{15}$

I am a great believer in active case management from the time the file hits my chambers ... The procedures and the steps that we put in place from the outset in handling what I'd call mega-litigation in these chambers is that we take control of it. The parties don't control it. And we keep an active eye on exactly what's happening. ${ }^{16}$

Note the rejection, here, of the principle of party control: the mega-litigation judge sees it as their role to take control away from the parties. Their task is not only to determine the legal and factual issues presented by the parties.

What exactly does this active, interventionist case management involve? For one thing, it requires, from an early stage in the life of the proceedings, regular directions hearings or management conferences at which the progress of the case is discussed in detail. ${ }^{17}$ As the matter progresses, the judge continues to keep 'an active eye on exactly what's happening'. ${ }^{18}$ One participant recalled seeing the parties to a megalitigation matter 'usually at least once a week, sometimes twice or even more times a week. Just to keep a very close hand on what was going on.' ${ }^{19}$ These hearings can cover every aspect of the management of the proceedings, from defining the issues to arranging the practical aspects of the trial. In order to make the most of these hearings, the judge must become familiar with all aspects of the case; in the words of one interview participant, 'at a judicial level you've got to know it better than they [the parties] do. ${ }^{20}$

The most significant and consistent theme emerging from interview participants' discussion of their case management practices was that an important part - perhaps the most important part - of the role of the managing judge is to help the parties

14 Interview with Participant F.

15 Interview with the Honourable Ray Finkelstein QC (Melbourne, 21 November 2012).

16 Interview with Participant E.

17 Interview with the Honourable Ray Finkelstein QC (Melbourne, 21 November 2012); Interview with Chief Justice Wayne Martin (Perth, 6 March 2013); Interview with the Honourable Neville Owen (King's Park, WA, 5 March 2013); Interview with Participant D.

18 Interview with Participant E.

19 Interview with Chief Justice Wayne Martin (Perth, 6 March 2013).

20 Interview with Participant E. Participant D emphasised the importance of preparation before the directions hearings got underway. Peter McClellan said the judge needed to keep up with the factual material as it came in: Interview with Justice Peter McClellan (Sydney, 5 June 2012). 
define the issues in mega-litigation. ${ }^{21}$ Participants adopted varying techniques in fulfilling this role. Some developed semi-formal processes for defining the issues:

You have to have a very clear view from the outset about what are the disputed factual and legal issues. And so you have to engage with the parties from the very outset. So I say to them at the first hearing 'what are the issues in this case?' And they get an email from my chambers [before the first hearing] which says 'You must be in a position to discuss substantively what are the disputed issues of fact and law' ... And we put in place from the very first step an absolute requirement that they identify them up front. And we say to them 'are they truly in dispute?' If they are then we'll prove them, if they're not then I want to know about it now. ${ }^{22}$

I think early identification of the issues is really the key to preventing the megalitigation getting out of hand. The judge has a real role in that exercise. And ... we do that through a process we call a strategic conference, which is fairly early in the life of the case, we'll get all the parties and the lawyers and their clients around a table and ask them for an oral presentation on what they see the real issues are and then working out the shortest, most effective path between where we are then and the resolution of those issues. ${ }^{23}$

One of my approaches in a case is always to require the parties to define the issues and produce an agreed statement in writing. I don't care if they disagree as to some but I want it there. I've always done that and I always will. And I tell them that I'm going to resolve the case according to those issues, so if they don't put it in that's their problem. ${ }^{24}$

The most common technique used to narrow the issues, however, was debate at case management hearings:

The idea is I think to have techniques to isolate what are the critical things and try and keep the parties to dealing only with the critical things that bear on the outcome of the case. ... I'm a highly active participant in argument. So vigorous debate is my technique of trying to isolate the issues and get parties to abandon what doesn't matter. ... You have to have the ability to take a morass of material and extract from it what it is really the parties are fighting about. Now often you have to take the lead in that by asking questions. Questioning counsel,

21 Interview with the Honourable Michael Black AC QC (Melbourne, 22 November 2012); Interview with Justice David Bleby (Adelaide, 16 February 2012); Interview with Justice David Harper (Melbourne, 19 November 2012); Interview with Justice Robert McDougall (Sydney, 6 June 2012); Interview with Chief Justice Wayne Martin (Perth, 6 March 2013); Interviews with Participants A, E, F, G and H.

22 Interview with Participant $\mathrm{E}$.

23 Interview with Chief Justice Wayne Martin (Perth, 6 March 2013).

24 Interview with Justice Robert McDougall (Sydney, 6 June 2012). 
questioning propositions, telling them what you don't understand, where you need assistance and so on and so forth. ${ }^{25}$

Rigorous, rigorous exploration of the real issues with the parties [is the key to managing mega-litigation]. ... There's just no place for [the parties] to hide ... if you want to say that, why do you say it? Drill down into the real case of the parties ... with serious determination to get to the bottom of it and to get rid of everything else. ${ }^{26}$

Without forcing people unfairly to limit the issues, you can debate the issues which will be determinative. People can be persuaded to give up useless parts of the case. ${ }^{27}$

It may be ... that when the matter first comes before the court we need to look and say 'you' ve got a 400 page statement of claim here. It goes on and on and says the same thing in 15 different ways. Why? I'm not going to accept it. Go away, identify the issues, and replead it.' That may nip some things in the bud.28

The issues that arise are those that are identified in pleading. But that will often require the judge to have an interaction with the representatives of the parties at an early stage: 'What do you mean by this? Do you really want to plead this as the ninth possible alternative ...? How are you going to cater for the possible combinations and permutations that might arise because of the alternative pleadings? Can't we proceed right to this as the crucial issue? Is there some particular factual question that can be identified as the key and perhaps dealt with before we deal with some of these other questions? Can we identify particular matters on which there'll be one expert on each side and defer getting any other expert evidence until we've resolved this?' ${ }^{29}$

The parties come to you for the first directions hearing. You start asking what the case is all about and what the defences are, what the issues are, how do we prepare it for trial, what are we going to need. ... You just say 'what's this all about? Is it all about this thing in the pleading?' And I've been doing this because you can actually force them, you can say 'well, I want to know whether this is being defended. What is the answer to this? Why are we taking time up on this?'30

The vigour with which this debate was pursued varied. Some participants said they would do no more than 'lean on' ${ }^{31}$ the parties to encourage them to narrow the

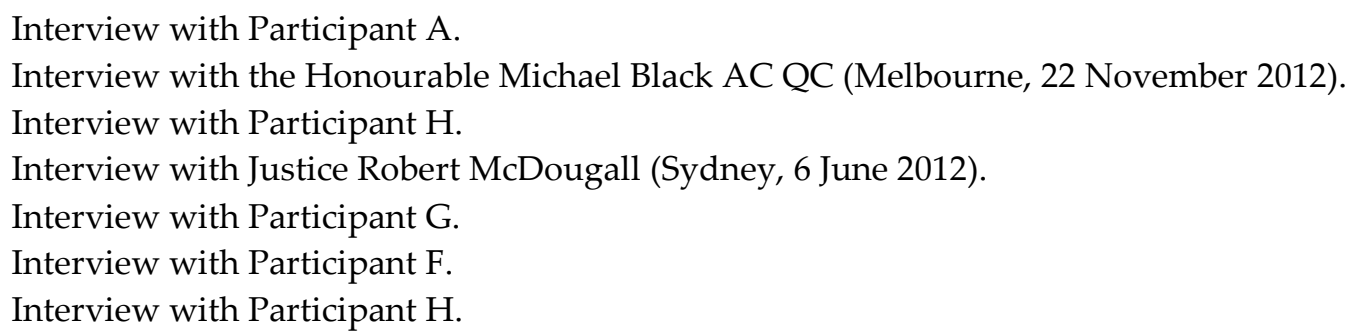


issues; or that they had an active role in 'helping the parties to define the issues' ${ }^{32}$ rather than defining those issues themselves. At the more forceful end of the scale was the Honourable Ray Finkelstein QC:

If I thought that issues were hopeless I simply would not allow the parties to run them. I would say 'I've looked at the point and it has no merit. You are going to lose it.' So I would shut down the hopeless issues. ${ }^{33}$

At this end of the scale, the judge takes on a role remote from the traditional aloof adjudicator of issues presented by the parties. ${ }^{34}$ It is worth recalling Denning LJ's warning that the judge in an adversarial system ought not to drop the mantle of a judge' and assume 'the robe of an advocate'. ${ }^{35}$ In earlier times, the role of the judge was likened to that of a cuckoo in a clock:

On the 'cuckoo clock' view, the judge comes out when required, performs his judicial functions, and goes back into his chambers. On this view, the court system has no responsibilities in respect of delay in bringing the claim before the court, in the progress of it through the court processes, or in respect of the delay which takes place during trial. All of these are to be left to the parties. ${ }^{36}$

The role of a modern case-managing judge is fundamentally different from that of the cuckoo clock judge. One interview participant said that 'for me the cuckoo judge is a thing of the past. They don't exist. This idea that you just walk into court and someone will tell you what the case is about went out with the Ark.' ${ }^{37}$ The role of the judge has evolved from passive adjudicator to active manager, and control has shifted from the parties to the judge. Chapters 6 and 7 explained these trends in civil procedure generally. Mega-litigation has not escaped these trends; in fact, megalitigation appears to call for an exceptionally robust approach to case management, and a high degree of involvement from the judge.

As well as helping the parties define the issues, the mega-litigation judge also supervises the procedural progress of the litigation. Case management hearings are an opportunity to plan all aspects of the case: discovery, interlocutory procedures, alternative dispute resolution, and the conduct of the trial. Chapter 9 will outline some of the specific instances in which mega-litigation judges become involved in the detailed management of the case: working out which documents need to be

\footnotetext{
32 Interview with Chief Justice Wayne Martin (Perth, 6 March 2013).

33 Interview with the Honourable Ray Finkelstein QC (Melbourne, 21 November 2012).

34 See the discussion in Chapter 6 at 94-5.

35 Jones $v$ National Coal Board [1957] 2 QB 55, 64. The full passage is set out in Chapter 6 at 88.

36 Justice DL Mahoney, 'Delay ... A Judge's Perspective' (1983) 57 Australian Law Journal 30, 35.

37 Interview with Participant E.
} 
discovered; asking whether any issues lend themselves to separate determination; setting timetables for the trial and for interlocutory steps; managing experts; working out how the evidence and argument is to be presented; and setting up technology systems. Case management is a mechanism for implementing these techniques.

By assuming this active role, the mega-litigation judge takes on a massive out-ofcourt workload. One general criticism of case management is that it requires a lot of work from the judge; a factor that sets off the efficiency gains achieved elsewhere. ${ }^{38}$ Interview participants acknowledged that active management of mega-litigation was a labour-intensive endeavour. ${ }^{39}$ One Supreme Court judge nominated the management burden on the judge as the major qualitative difference between megalitigation and other litigation:

The management of mega-litigation is extremely burdensome on a judge, and that's the most qualitative [difference from other litigation]. The thing about case management is that to do it properly involves a huge burden on the court. In the olden days when there was no case management it involved no burden on the court - and I suppose that was why it was inefficient. ${ }^{40}$

As this participant's comments indicate, participants generally accepted the burden of case management as the necessary price of efficiency:

It is labour-intensive, but the alternative is a disaster. It's a disaster for the parties for the cost consequences, it's a disaster for the parties because they end up addressing issues which may not be in dispute ... and it's a disaster for the judge ... because when you come to write the judgment, if you don't know it I don't know how you do it. ... I actually think that the intensity of the effort in preparation and immediately before trial is essential. Because otherwise I don't know how you can run it, I don't know how you can control it and I don't know how you can write a judgment - efficiently. ... So I don't think we've got a choice. ${ }^{41}$

38 See discussion in Chapter 6 at 93-4; IR Scott, 'Caseflow Management in the Trial Court' in AAS Zuckerman and Ross Cranston (eds), Reform of Civil Procedure: Essays on 'Access to Justice' (Clarendon Press, 1995) 1, 18; Sir Gerard Brennan, 'Key Issues in Judicial Administration' (1996) 6 Journal of Judicial Administration 138, 139.

39 Interview with Justice David Bleby (Adelaide, 16 February 2012); Interview with Justice Peter McClellan (Melbourne, 5 June 2012); Interviews with Participants A, D, E and H.

40 Interview with Participant A.

41 Interview with Participant E. 
As a matter of necessity, then, the mega-litigation judge engages with the legal, factual, evidential and procedural issues in depth from an early stage in the proceedings.

This active role is a far cry from the cuckoo clock judge of the past. ${ }^{42}$ As explained in Chapters 6 and 7, interventionist case management has become an accepted practice in most Australian jurisdictions. In a sense, mega-litigation is simply part of this trend. But in mega-litigation, we see case management at its most extreme. Judges are intensely involved at every stage of proceedings. Active case management is seen as indispensable - not optional - to the effective management of megalitigation. Judges in mega-litigation are willing to push case management to its limits in a quest to improve efficiency. This quest often leads to innovation. Mega-litigation judges do not just use existing case management techniques; they create new ones.

\section{B Creative}

The interview data showed that many participants approached procedure in a creative way. ${ }^{43}$ Participants described the mega-litigation judge as 'creative', ${ }^{44}$ 'innovative', ${ }^{45}$ 'lateral thinking' ${ }^{46}$ and 'imaginative' ${ }^{47}$ The Honourable Neville Owen said he was 'continually working on ideas to try and improve' procedure in megalitigation. ${ }^{48}$ The mega-litigation judge is not restricted to choosing from a range of established procedural options; they can in fact 'inven[t] procedures on the run'. ${ }^{49}$ Some manifestations of this judicial creativity will be discussed in Chapter 9. We will see that mega-litigation judges invent new ways of dealing with discovery and

42 This is not the first qualitative study of judges' behaviour to identify markedly active, nontraditional styles of judging; in their 1979 study of American trial judges Galanter, Palen and Thomas observed that judges brought a degree of 'activism' to various aspects of their role, which contrasted with the 'prototypical common law trial judge': Marc Galanter, Frank S Palen and John M Thomas, 'The Crusading Judge: Judicial Activism in Trial Courts' (1979) 52 Southern California Law Review 699.

43 Interview with the Honourable Michael Black AC QC (Melbourne, 22 November 2012); Interview with the Honourable Ray Finkelstein QC (Melbourne, 21 November 2012), Interview with the Honourable Malcolm Lee QC (Fremantle, 6 March 2013); Interview with Chief Justice Wayne Martin (Perth, 6 March 2013); Interview with Justice Robert McDougall (Sydney, 6 June 2012); Interview with the Honourable Neville Owen (King's Park, WA, 5 March 2013); Interviews with Participants A, E, G and H.

44 Interview with Participant $\mathrm{H}$.

45 Interview with Justice Robert McDougall (Sydney, 6 June 2012).

46 Interview with Chief Justice Wayne Martin (Perth, 6 March 2013).

47 Interview with the Honourable Michael Black AC QC (Melbourne, 22 November 2012).

48 Interview with the Honourable Neville Owen (King's Park, WA, 5 March 2013).

49 Ibid. Participant E said 'we set up our own rules' and Participant A said 'In the case management era, all the rules are man-made as you go along'. The flexibility of the megalitigation judge is explored in more detail below at 141-4. 
experts; make the most of modern technology; abandon traditional trial structures; and find new uses for old procedures such as splitting trials and taking evidence on commission.

Through the creative development of new techniques, mega-litigation has been a catalyst for some important changes in civil procedure generally. Ross Cranston credits complex cases as 'the driver for the modern theories of case management which developed in the United States.' ${ }^{50}$ In Australia, mega-litigation has been at the forefront of the use of technology in trials. ${ }^{51}$ As judges develop creative ways of dealing with the challenges of mega-litigation, the benefits may flow not only to the management of mega-litigation but to the justice system as a whole.

To some extent, this creativity is born of necessity. There are few 'reliable written record[s]' of the way in which mega-litigation has been handled in the past, leading mega-litigation judges sometimes to feel as though they are 'reinventing the wheel'. ${ }^{52}$ Participants did not report receiving any formal preparation for hearing megalitigation. They looked to a range of sources for guidance. Some participants picked up ideas at judges' conferences. ${ }^{53}$ Some found that informal discussions with other judges were helpful; one Federal Court judge reported that these discussions occurred

All the time. Just constantly about procedural issues that arise in cases, things to try to make cases more streamlined and run more smoothly. That would be a constant flow of information. ${ }^{54}$

Ray Finkelstein explained how he drew ideas from his own experience, from literature from other (mainly US) jurisdictions, and from discussions with research assistants recruited from the US. He then put these ideas into practice: 'It sort of becomes trial and error. You ... implement something; if it does not work adopt

50 Ross Cranston, 'Complex Litigation: The Commercial Court' (2007) 26 Civil Justice Quarterly 190, 201. Cranston refers, in particular, to 1951's Prettyman Report (Judicial Conference of the United States, Procedure in Anti-Trust and Other Protracted Cases (1951), reprinted in (1951) 13 Federal Rules Decisions 41). Cf Richard L Marcus, 'Reassessing the Magnetic Pull of Megacases on Procedure' (2001) 51 DePaul Law Review 457 (arguing that mega-litigation does not necessarily lead to procedural innovation); Judith Resnik, 'Changing Practices, Changing Rules: Judicial and Congressional Rulemaking on Civil Juries, Civil Justice, and Civil Judging' (1997) 49 Alabama Law Review 133, 188-95 (arguing that procedural innovations developed in complex cases should not necessarily be adopted in ordinary cases).

51 See Chapter 10 at 194-8.

52 Class Action and Electronic Trial Guide, Federal Court of Australia (2012) (Copy on file with author).

53 Interview with Justice David Bleby (Adelaide, 16 February 2012); Interview with Participant F.

$54 \quad$ Interview with Participant B. 
something else.'55 Neville Owen, when asked where his ideas for innovative procedures came from, replied '[j]ust from here, usually' and pointed to his head. ${ }^{56}$

Creativity involves risk. Reflecting on the unconventional methods he had used to deal with expert evidence in a large competition law case, ${ }^{57}$ Ray Finkelstein said he was not sure whether the process would have survived an appeal. He was not daunted by this prospect:

I thought that if somebody wanted to appeal, well and good. Because unless judges try something new and run the risk of successful appeal, (in fact I was not even sure what I would do if I was sitting on the appeal court) the system never changes. ${ }^{58}$

Evidently, the creativity of a mega-litigation judge is, to some extent, a personality trait. Not every judge would be willing to take calculated gambles in pursuit of efficiency. Some may not consider it appropriate for judges to be taking such gambles. Certainly, the creativity exhibited by interview participants is at odds with a conservative view of the judicial role.

Participants' willingness to assume an active, creative role suggests the existing rules and procedures - and indeed the traditionally passive judicial role - are not always adequate to meet the needs of mega-litigation. Judges have responded to the shortcomings of the existing framework by taking matters into their own hands.

\section{Flexible}

As well as creating new procedures, mega-litigation judges adapt existing procedures to fit the circumstances of each case. Participants described their approach to procedure in mega-litigation as 'flexible'59 and 'bespoke',60 they were able to 'meld'61 or 'tailor' 62 procedures as needed.

\footnotetext{
55 Interview with the Honourable Ray Finkelstein QC (Melbourne, 21 November 2012).

56 Interview with the Honourable Neville Owen (King's Park, WA, 5 March 2013).

57 The evidence of approximately 50 experts was taken in a series of round table conferences, in which the judge led the witnesses, with counsel permitted to ask questions only after the judge's questioning was complete. The parties were excluded from the conference room, but the hearing was broadcast via CCTV. The process is described in Chapter 9 at 188-9.

58 Interview with the Honourable Ray Finkelstein QC (Melbourne, 21 November 2012).

59 Interview with Chief Justice Wayne Martin (Perth, 6 March 2013); Interview with Participant H.

60 Interview with Chief Justice Wayne Martin (Perth, 6 March 2013).

61 Interview with Justice David Harper (Melbourne, 19 November 2012).

62 Interview with the Honourable Neville Owen (King's Park, WA, 5 March 2013).
} 
The active case management discussed earlier in this chapter ${ }^{63}$ facilitates this flexibility. Active case management involves, among other things, intense questioning, at an early stage, about what the real issues are and how the parties are going to run their case. ${ }^{64}$ Through this questioning, the judge can become familiar enough with the case to tailor procedures to suit the circumstances. Decisions about how to conduct discovery, about whether it is appropriate to refer questions to a referee or to split the trial, about how to receive evidence, how to manage experts and how to structure the trial can be made on a case-by-case basis, based on a deep understanding of the case and on searching discussions with counsel.

The flexible approach of mega-litigation judges, and the status of procedural rules as guidelines rather than rigid requirements, is a manifestation of a trend in civil procedure generally. Chapter 6 explained that procedure has moved away from the pre-Judicature Acts preoccupation with 'excessive technicality and absorption in mere forms', ${ }^{65}$ when courts 'saw it as their main task to secure strict adherence with process requirements.' 66 In the late 19th century, this formalistic approach was swept away in favour of the 'justice on the merits' approach, ${ }^{67}$ in which procedure is the 'handmaid' 68 of justice rather than vice versa. In mega-litigation we see this approach taken to its extreme: the task of a mega-litigation judge is too flexible, intuitive and collaborative to be captured in a series of rules.

The need for a flexible, tailored approach is reflected in court rules. The rules in most jurisdictions give judges broad powers to dispense with compliance with the rules, ${ }^{69}$ and to make any directions appropriate in each case. ${ }^{70}$ Western Australia's Chief Justice Wayne Martin explained how such rules, combined with the use of a docket system, affect the approach to case management:

\footnotetext{
63 At $132-9$.

$64 \quad$ See discussion above at 135-7.

65 Sir Jack IH Jacob, 'Civil Procedure Since 1800' in Sir Jack IH Jacob, The Reform of Civil Procedural Law (Sweet \& Maxwell, 1982) 193, 197.

66 Adrian Zuckerman, Zuckerman on Civil Procedure: Principles of Practice (Sweet \& Maxwell, $2^{\text {nd }}$ ed, 2006), 25.

67 See Chapter 6 at 85-9.

68 Re Coles and Ravenshear [1907] 1 KB 1, 4 (Collins MR).

69 See, eg, Federal Court Rules 2011 (Cth) r 1.34; Court Procedures Rules 2006 (ACT) r 6; Supreme Court (General Civil Procedure) Rules 2005 (Vic) r 2.04.

$70 \quad$ Federal Court Rules 2011 (Cth) r 1.32; Court Procedures Rules 2006 (ACT) r 1401; Uniform Civil Procedure Rules 2005 (NSW) r 2.1; Supreme Court Rules (NT) r 34.01; Uniform Civil Procedure Rules 1999 (Qld) r 367; Supreme Court Civil Rules 2006 (SA) r 117; Supreme Court (General Civil Procedure) Rules 2005 (Vic) r 34.01.
} 
Under our rules, once a case is in the docket-based judge-managed list ... we have a rule that says the judge case-manager can do whatever he or she thinks is appropriate in the interests of justice. And then we have a list saying 'these are some of the orders that a judge manager can make', and there's about 30 of them. ... So the old prescriptive 'one size fits all, first you plead then you've got 14 days for defence', we've gone away from that entirely. We have a much more flexible, bespoke approach, supervised by a docket case manager. ... We've got away from the formulaic, prescriptive [approach]. It's all case managed with a view to focusing on that case. ${ }^{71}$

The Honourable Malcolm Lee QC appreciated the flexibility afforded by the Federal Court Rules:

I think the rules work quite well in the Federal Court, with everyone understanding that they were never going to be used against you, that they were guidelines to getting the matter rolling but lawyers know they cannot use the rules as a vehicle to take points and wear out opponents. ... So in other words the rules don't run the show. ${ }^{72}$

Two participants expressed a similar view in even stronger terms. One Federal Court judge was 'a great supporter of the very flexible rules we have, that basically mean you can do what you want.' 73 In a recent mega-litigation matter, this judge had not found it necessary to rely on specific court rules: 'I didn't use them. I don't think we even opened them. We set up our own rules really.' ${ }^{74}$ Another participant - this time a Supreme Court Judge - reported similar experiences:

The fact is that in mega-litigation there are no rules. In the case management era, all the rules are man-made as you go along. ... There are no rules, really. It's just what I decide. ${ }^{75}$

These remarks suggest that the successful management of mega-litigation largely depends upon the choices made by the judge handling the case, rather than on system-wide rules and structures. Participants saw this as a good thing: they appreciated the free rein that the rules (or lack thereof) afforded. But there are two obvious concerns with this situation. The first is that system-wide improvement of the management of mega-litigation is unlikely if each judge is able to make their own rules in isolation. There may even be a danger that, if giving judges procedural freedom is seen as the answer to the problems of mega-litigation, the potential for

\footnotetext{
71 Interview with Chief Justice Wayne Martin (Perth, 6 March 2013).

72 Interview with the Honourable Malcolm Lee QC (Fremantle, 6 March 2013).

73 Interview with Participant E.

$74 \quad$ Ibid.

75 Interview with Participant A.
} 
broader reforms will be ignored. A partial answer may be that flexibility and creativity foster procedural innovation, which in turn can be disseminated across the court system. I return to the role of judicial education in the conclusion to this thesis. ${ }^{76}$

The second concern is that procedures will become idiosyncratic and unpredictable. Procedure will also become vulnerable to each individual judge's views about the priorities of civil procedure. A judge who is devoted to justice between the parties may pursue that objective to the exclusion of all else, resulting in gross inefficiency. A judge who places high priority upon public justice or public efficiency may pursue those objectives at the expense of justice between the parties. At the extreme end of the scale, errors may be corrected on appeal, with reference to overarching purpose provisions $^{77}$ and High Court authorities on procedure. ${ }^{78}$ However, appeals against procedural decisions occur relatively infrequently, and the role of the appeal court is restricted by the principle that appeal courts ought not to interfere with the exercise of a procedural discretion except in exceptional circumstances. ${ }^{79}$ Furthermore, the flexibility of the rules means that it is more difficult for an appeal court to find that an error has occurred.

Flexibility, then, as a characteristic of the mega-litigation judge, means that the way in which mega-litigation is managed depends to a large extent on the skill of the individual judge. I return to this point later in this chapter. ${ }^{80}$

\section{Fair}

The picture of the mega-litigation judge that has emerged from this chapter so far is of someone who actively, even aggressively, pursues efficiency, unbound by traditional ideas about how courts act. Are there limits to the mega-litigation judge's pursuit of efficiency? For a majority of interview participants, ${ }^{81}$ the limit could be

\section{$76 \quad$ At $246-7$.}

$77 \quad$ Discussed in Chapter 7 at $115-18$.

78 Discussed in Chapter 7.

$79 \quad$ Australian Coal and Shale Employees' Federation v Commonwealth (1953) 94 CLR 621, 627 (Kitto J); Squire v Rogers (1979) 39 FLR 106, 113-14 (Deane J); Sackville-West v Attorney-General (1910) 128 LT Journ 265; Bomanite Pty Ltd v Slatex Corp Aust Pty Ltd (1991) 32 FCR 379, 386-7 (Gummow J), 391 (French J); Queensland v JL Holdings Pty Ltd (1996) 189 CLR 146, 163 (Kirby J).

80 At $149-55$.

81 Interview with the Honourable Michael Black AC QC (Melbourne, 22 November 2012); Interview with Justice David Bleby (Adelaide, 16 February 2012); Interview with Justice David Harper (Melbourne, 19 November 2012); Interview with the Honourable Malcolm Lee QC (Fremantle, 6 March 2013); Interview with Justice Peter McClellan (Melbourne, 5 June 2012); Interview with Justice Robert McDougall (Sydney, 6 June 2012); Interview with the Honourable Neville Owen (King's Park, WA, 5 March 2013); Interviews with Participants A, B, D and F. 
found in the fundamental obligation of the mega-litigation judge - or indeed any judge - to act fairly. When asked to identify the limits on judicial intervention and efficiency measures, ${ }^{82}$ participants consistently nominated procedural fairness as the 'touchstone', 83 the 'minimum right of procedure' 84 and as a 'fundamental' 85 value of courts. For some participants the importance of procedural fairness rested on the institutional characteristics of courts: one participant said that procedural fairness was 'what distinguishes courts from other decision-making bodies.' 86 For Neville Owen, the concern for procedural fairness had an internal source: 'it's just ingrained, it's just part of my being'. ${ }^{87}$

One aspect of procedural fairness was at the forefront of many participants' minds when running mega-litigation: the obligation to afford parties a hearing, even though this might add to the time or cost of the litigation. The view of one Supreme Court judge was typical: 'you have to make sure that the case finishes within reasonable parameters but you also have to make sure the parties feel they're getting a proper hearing' ${ }^{88}$ Neville Owen acknowledged there could be a conflict between the demands of efficiency and fairness, but in those circumstances 'fairness won':

If it's necessary to be inefficient, to ensure the fairness of the process - not the result but the fairness of the process - then that's the way it has to be. There was one issue in [the Bell Group trial] which probably accounted for a month overall, where that fairness question arose. I had to 'stretch' the construction of the pleadings which allowed a party to bring in a whole raft of new evidence. And that was a fairness thing where I could have just said to them 'you're just not going to do it, that's the pleaded case, stick within that' ${ }^{89}$

This passages carries an echo of the 'process values' introduced in Chapter 5:90 it was necessary to provide a full hearing in order to ensure the fairness of the process, as distinct from the result.

82 This happened at various points of the interviews: when discussing the theories of Summers and Dworkin (see Chapter 5), when discussing the aims of civil procedure and the tension between justice and efficiency; and when discussing particular techniques used in megalitigation.

83 Interview with the Honourable Michael Black AC QC (Melbourne, 22 November 2012).

$84 \quad$ Interview with Participant D.

85 Interview with Justice Peter McClellan (Melbourne, 5 June 2012); Interviews with Participants B and F.

86 Interview with Participant G.

87 Interview with the Honourable Neville Owen (King's Park, WA, 5 March 2013).

88 Interview with Participant A.

89 Interview with the Honourable Neville Owen (King's Park, WA, 5 March 2013).

$90 \quad$ At $75-80$ 
Fairness in the sense of impartiality is another challenge for mega-litigation judges. Two participants spoke of the difficulty of combining intensive case management with traditional concepts of judicial impartiality. Justice David Harper explained that, through intensive case management, the judge will build up knowledge about the evidence that is likely to be led at trial. As a result,

the judge may very well have a sense of where the trial's going to go. But while having that sense you've also got to tell yourself that you must not prejudge. ... In the pre-trial process there is ... the need and the danger of coming to tentative conclusions. And you have to remind yourself all the time that they are tentative only. It may be that they will be very helpful in the end, but they also pose the danger that you will do the parties injustice by making rulings in the interlocutory process that inhibit one or other of the parties from presenting the case as it would like to do. ${ }^{91}$

Neville Owen experienced a similar dilemma in Bell Group, this time during the trial. He explained that he found it useful to express tentative views about the merits of the parties' cases on particular issues, in order to focus their attention on the most important issues. But he was constantly aware of creating the appearance of bias and was 'as circumspect as possible' in the expression of views:

There were a couple of issues ... where I was, I think, a little too clear in what I thought of aspects of the case. That can be dangerous. But I learned from that, I tempered it after that. Sometimes I'd raise my eyebrows and say 'oh, really?' But I tried to be as circumspect as I could because the worst thing that could have happened was for a party to say 'you're biased' ${ }^{92}$

Procedural fairness, then, appears to be the line even the most active, interventionist mega-litigation judge will not cross. But procedural fairness is not a rigid standard. Procedural fairness 'does not require the inflexible application of a fixed body of rules; it requires fairness in all the circumstances'. ${ }^{93}$ The rules of procedural fairness have never meant that the parties must be given an unlimited opportunity to present their case; ${ }^{94}$ on the contrary, the rules 'in a particular case must always be moulded

91 Interview with Justice David Harper (Melbourne, 19 November 2012).

92 Interview with the Honourable Neville Owen (King's Park, WA, 5 March 2013).

93 National Companies and Securities Commission v News Corporation Ltd (1984) 156 CLR 296, 312

(Gibbs CJ); see also $R v$ Commonwealth Conciliation and Arbitration Commission; Ex parte The Angliss Group (1969) 122 CLR 546, 552-3 (Barwick CJ, McTiernan, Kitto, Taylor, Menzies, Windeyer and Owen JJ); Mobil Oil Australia Pty Ltd v Federal Commissioner of Taxation (1963) 113 CLR 475, 504 (Kitto J); Kioa v West (1985) 159 CLR 550, 585 (Mason J).

94 In the courts of ancient Rome, the time allowed for advocates to address the court was determined by the use of a water clock or 'clepsydra': an earthenware vessel with a hole in the bottom. The clepsydra would be filled with water at the start of the advocate's submissions 
to the particular circumstances of that case. ${ }^{95}$ In accordance with these principles, several participants acknowledged that procedural fairness has its limits: ${ }^{96}$

I don't believe in an absolute right to call every witness and turn over every stone without some reasonable prospect of it being relevant to the determination of the real issues in the case. The real - and not the imagined or possible - issues. ${ }^{97}$

There has to be a minimum level of procedure to ensure there's a fair trial. That extends to pleadings, expert witness statements, discovery, but within limits. It's reaching the balance between cost and a minimum requirement of fairness. ... One thing we have learnt in the last ten years is you just can't have open-ended justice, in other words that everything goes ahead without regard to the cost and the expense and the efficiency of the litigation. And so we have to limit the parties' theoretical rights to call as many experts as they want for example, to discover every possible document that's ever been published in the world about a particular topic, to thrash out issues that aren't real issues at the trial. ${ }^{98}$

I think that you have to [limit the right to be heard in mega-litigation]. I have no doubt that limitations on cross-examination, limitations even on examination-inchief, are necessary in order to contain the area of dispute and in the end to do justice not only to the parties to the litigation in reducing the cost and the time that litigation takes, but also to the court system and the other litigants who are caught up in the court system. ${ }^{99}$

It's not a free for all ... [A fair hearing is fundamental but] that's by no means to say that your perception of what might be just is the same as the parties'. Now that could manifest itself in the number of witnesses you allow them to call in total, the number you allow to be called on a particular topic, the number of experts you allow to be called, ... the length of time of cross-examination, length

and when the last of the water had drained away, the advocate's time was up. The clepsydra would be refilled for the submissions of the other party's advocate. Larger vessels were used for more serious cases. Advocates would sometimes request additional clepsydrae. This very early efficiency measure demonstrates a recognition that a hearing could be strictly limited yet still be fair. See Jerome Carcopino, Daily Life in Ancient Rome (EO Lorimer trans, George Routledge \& Sons, 1941), 186; Rebecca R French, 'Time in the Law' (2001) 72 University of Colorado Law Review 663, 679; Robert Levine, A Geography of Time (Basic Books 1997), 55. Applicant VEAL of $2002 v$ Minister for Immigration and Multicultural and Indigenous Affairs (2005) 225 CLR 88, 99 (Gleeson CJ, Gummow, Kirby, Hayne and Heydon JJ).

96 Interview with the Honourable Michael Black AC QC (Melbourne, 22 November 2012); Interview with the Honourable Ray Finkelstein QC (Melbourne, 21 November 2012); Interview with Justice David Harper (Melbourne, 19 November 2012); Interview with Justice Peter McClellan (Melbourne, 5 June 2012); Interviews with Participants B, D and G.

97 Interview with the Honourable Michael Black AC QC (Melbourne, 22 November 2012).

98 Interview with Participant D.

99 Interview with Justice David Harper (Melbourne, 19 November 2012). 
of time for oral submissions. All of those matters, well they're all listed [in the rules] as things you can make directions about. ${ }^{100}$

Procedural fairness being afforded doesn't mean that you can't manage large scale litigation, press the parties to define issues, limit the amount of evidence they can give and so forth. Because procedural fairness itself depends upon the circumstances, the context ... Before we had the case management revolution [the position was] that every litigant is entitled to run his or her own case, to the lengths that that litigant considers appropriate in order to ensure that the litigant has every opportunity to put every argument of fact or law that may be available. But we can't afford that, and so there have to be limits imposed. ... Of course we recognise that procedural fairness is essential to the operation of the judicial system. But that doesn't mean that a party has to have unlimited opportunities to pursue the case. ${ }^{101}$

It's the opportunity to provide evidence and ask questions which is fundamental to our system. [But that is] absolutely not [unlimited]. It's confined ... under our current system by the fact that the State is paying the cost and providing the structure, which is a very significant cost and one the State will increasingly find burdensome. ${ }^{102}$

These quotes reflect the view that, as I have argued throughout this thesis, civil procedure serves multiple aims. The participants quoted above did not see their role as limited to doing justice between the parties. They were mindful of public efficiency (in taking into account the cost to the State) and public justice (in considering the effect of mega-litigation on other litigants). The latter two considerations could justify placing limits on the way parties to mega-litigation run their case.

Some of these quotes also emphasise the importance of focusing on the real issues in the case. Participants saw focus on the issues as a way of limiting the scope of the hearing without compromising the parties' ability to present their case on the heart of the dispute, and therefore without departing from the principles of procedural fairness. Once again, this position rests on the rejection of party control as a premise of civil procedure. Limiting the issues will generally involve excising portions of the parties' case that do not bear upon the real issues. One participant referred to 'the real - and not the imagined or possible - issues'. ${ }^{103}$ Yet the 'imagined or possible' issues are issues that the parties and their lawyers believed, at some stage, were

\footnotetext{
$100 \quad$ Interview with Participant B.

101 Interview with Participant G.

102 Interview with Justice Peter McClellan (Melbourne, 5 June 2012).

103 Interview with the Honourable Michael Black AC QC (Melbourne, 22 November 2012).
} 
worth litigating. In that sense, focusing on the real issues may mean giving the parties something less than the hearing they would have chosen for themselves. This is not necessarily a problem. As explained in Chapter 2,104 doing justice between the parties need not mean giving the parties whatever they want.

\section{PERSONALITY AND EXPERIENCE}

The characteristics of a mega-litigation judge identified in this chapter - active, flexible, creative, and fair - are not necessarily characteristics that all judges possess. The first three of these four attributes may run counter to the traditional role of the judge as a passive adjudicator. The legal profession, with its inherent conservatism, is not necessarily conducive to producing proactive, lateral thinking candidates for judicial office. I do not want to exaggerate the effect of this conservatism; case management has been part of the litigation landscape for over two decades now, and some judges have come to the bench with the attributes of the mega-litigation judge described in this chapter. But it is important, for the purposes of this thesis, to consider the extent to which the management of mega-litigation depends upon the personal characteristics of the individual judge.

The interview data supports an argument that the way in which a judge manages mega-litigation is heavily influenced by that person's experience and personality. One participant, a former head of jurisdiction, said of the management of megalitigation:

Some judges are very good at this. Some aren't good at it at all. Some can be trained, which is better than no training. But others just don't like it, aren't instinctively good at it. I'm not speaking of any of my former colleagues; judges generally. ... I think you need the right judges to look at these things. ${ }^{105}$

Part of being 'the right' judge to handle mega-litigation is the judge's inherent personality. Speaking of procedural innovation and active case management, Ray Finkelstein said:

Some changes are personality driven. ... When commentators talk about the managerial judge, I think that judges who managed cases extensively - before it became the thing to do - did so by force of their personality. I think it was the human temperament. In other words, some judges said 'this is not working, and I am going to try better ways of doing it.' ... In whatever life they (the judge)

At 15 .

Interview with the Honourable Michael Black AC QC (Melbourne, 22 November 2012). 
would be in, they would try to bring about change. I think it's very much personality driven. ${ }^{106}$

One Supreme Court judge identified two personality traits as factors that made him a good manager of large cases: 'I've devoted a life to brevity. And ... I'm tough - or so perceived to be'. ${ }^{107}$ Other participants spoke of the need for 'confidence'108 and 'courage' 109 when managing mega-litigation.

As noted earlier, ${ }^{110}$ the importance of personality presents law reformers with a dilemma. If so much depends on the individual judge, how can systemic change be achieved? I return to this question in the conclusion to the thesis.

Experience, as well as personality, affects the way judges manage mega-litigation. Interview participants who had worked on complex litigation as solicitors or counsel consistently said this experience had been helpful when it came to managing megalitigation as judges. ${ }^{111}$ Several participants explained how their experience in complex litigation as a barrister of solicitor had helped them to understand the dynamics of mega-litigation. This experience helped them to appreciate 'the logistical problems that are involved from the side of the profession'112 and 'the difficulties about getting the case to court'. ${ }^{113}$ One Federal Court judge reflected on the way this understanding affected the management of mega-litigation as a judge:

[I] know that the demands that I make on counsel and solicitors are real demands. When you ask for something to be prepared it doesn't just happen, you know that it takes a lot. ${ }^{114}$

Some participants' experience as lawyers helped them understand the motivations of the parties. ${ }^{115}$ One participant said his experience as a lawyer contributed to his 'commercial understanding of significant and complex disputes'.116 Another

\footnotetext{
106 Interview with the Honourable Ray Finkelstein QC (Melbourne, 21 November 2012).

107 Interview with Participant A.

108 Interview with Participant G.

109 Interview with the Honourable Michael Black AC QC (Melbourne, 22 November 2012).

110 At 143-4.

111 Interview with the Honourable Ray Finkelstein QC (Melbourne, 21 November 2012); Interview with the Honourable Malcolm Lee QC (Fremantle, 6 March 2013); Interview with Chief Justice Wayne Martin (Perth, 6 March 2013); Interview with Justice Robert McDougall (Sydney, 6 June 2012); Interviews with Participants A, D, E, F and G.

112 Interview with Participant A.

113 Interview with Participant D.

114 Interview with Participant E.

115 Interviews with Participants A, D and E.

116 Interview with Participant A.
} 
explained how his work as a lawyer in class actions led him to take an approach to case-management which pushed parties towards an early trial:

If you're acting for defendants, generally in class actions they're insurers or large companies [that] want finality. That's the thing they're after. ... They want to have the case resolved. If you're acting for plaintiffs or a large group of people they ... also ... want a result. That's why so many [class actions] settle, and why trying to push the cases on towards trial as quickly as you can often produces a settlement. ${ }^{117}$

Another participant recalled attending board meetings of corporate clients involved in complex litigation:

The only questions, delivered in a variety of ways, [were] 'what are our risks? Who's the judge? Is he or she any good? When does the trial start? How long's it going to run? What are our prospects and, if we run it, how long's judgment away?' Why? Because they wanted to make a decision about whether to run [the case] or not run it, how much money is it going to cost to run it. ${ }^{118}$

As a result of this experience, the participant formed the view that it was important for the judge in mega-litigation to involve the clients at an early stage and, crucially, to make the issues in the case intelligible to the clients:

We've actually got to get them involved early and get them to understand it. And that means exposing them to not just their own little world but the other side's arguments as early as possible. ${ }^{119}$

Not only does this allow the clients to assess their risks and option; it can also help on a practical level. For example, this participant said clients who understood the issues at an early stage were likely to co-operate with reasonable requests for disclosure, because they understood which documents were likely to be relevant. Once again, this illustrates the importance of defining the issues as early as possible.

Participants also said their experience as lawyers made them aware of the tactical games lawyers play in mega-litigation:

Part of managing a case is understanding what they're up to. What are the lawyers trying to do? Is there some point to all of this? Are they just trying to pressure the other side? ${ }^{120}$

Interview with Participant D.

Interview with Participant E.

Interview with Participant G.

Ibid. 
Tactically, what counsel are trying to do, you can normally understand what they're up to [because of experience as a lawyer]. ${ }^{121}$

You know the jockeying that goes on. ... You understand the dynamics I think, better than if you had never been exposed to it. ${ }^{122}$

As counsel I experienced the pitfalls of mega-litigation, and as a judge managing those sort of cases I am cognisant of what people will do if you let them, and of ways of trying to head off the pitfalls into which cases of that kind can fall. ${ }^{123}$

Here we see that the task of the mega-litigation judge involves understanding and managing human behaviour; not just applying the law. Experience as lawyers gave participants insights into these matters which informed their management of megalitigation as judges.

Furthermore, participants found their experience as lawyers useful at a practical level. Several participants used their experience as a source of inspiration for creative ways of dealing with mega-litigation. ${ }^{124}$ Malcolm Lee drew lessons from his experience in major corporate criminal trials, recalling some of the techniques that were used to make complex expert evidence more accessible, to 'compress' voluminous evidence, to encourage parties to agree on non-contested points, and to make innovative use of technology. ${ }^{125}$ Wayne Martin found, while in practice, that face-to-face discussions between lawyers were more productive and less combative than written communication; he applied this principle in mega-litigation (and in case management generally) by insisting that some negotiations take place in person rather than in writing. ${ }^{126}$ Another participant had found, in mega-litigation as a lawyer, that written witness statements were generally unhelpful. This translated into a strong resistance to relying on written statements as a judge. ${ }^{127}$ Other participants said that their experience as lawyers meant that they knew the

\footnotetext{
121 Interview with Participant D.

122 Interview with Participant E.

123 Interview with Chief Justice Wayne Martin (Perth, 6 March 2013).

124 Interview with the Honourable Ray Finkelstein QC (Melbourne, 21 November 2012); Interview with the Honourable Malcolm Lee QC (Fremantle, 6 March 2013); Interview with Chief Justice Wayne Martin (Perth, 6 March 2013); Interviews with Participants A, E and F.

125 Interview with the Honourable Malcolm Lee QC (Fremantle, 6 March 2013).

126 Interview with Chief Justice Wayne Martin (Perth, 6 March 2013). The Chief Justice's view on this point is reflected in the Rules and Practice Directions, which require practitioners to confer face to face or by telephone prior to making an interlocutory application: Rules of the Supreme Court 1971 (WA) O 59 r 9; Supreme Court of Western Australia, Consolidated Practice Directions (2009) 4.3.2. 
procedural 'tricks of the trade'128 or the 'tricks about what works and what helps to narrow issues'. ${ }^{129}$

Participants' experience as lawyers gave them skills and abilities which made their task as mega-litigation judges easier. One Supreme Court judge said his time as counsel in mega-litigation had 'assisted me to learn the ability to assimilate huge amounts of information in a quick period of time.' ${ }^{\prime 30}$ Ray Finkelstein explained that his extensive experience as a trial lawyer meant that he 'knew how to run cases' and found it easier to make ex tempore procedural and evidentiary rulings:

If there's an objection to evidence I would rule on it on the spot. So those sort of things which come instinctively to trial lawyers translate quite well into practice as a trial judge. Looking at pleadings and working out whether or not they should be allowed. As a barrister you dealt with pleadings a thousand times it may take you a few minutes to deal with pleading summonses as a judge. So pleading summonses did not take me any time to deal with. I never agonised over them. With arguments about discovery, I would just look at the document and say 'discoverable or not discoverable'. ${ }^{131}$

Justice David Harper said that experience, as a practitioner and a judge, was crucial to his ability to manage complex litigation effectively:

One of the skills of the judge management process I think is for the judge to sense, through experience and through ability, to see where the case might be heading and where the issues might lie, and then assist the parties to direct their attention towards what the judge sees as being those elements of the litigation which will turn out to be crucial in the end. ... Experience counts for a huge amount. ${ }^{132}$

Other participants said that their experience as trial counsel enabled them to take a very active role in trials as a judge. Ray Finkelstein explained:

My experience as a trial barrister meant that if I was not happy with the way the questioning of witnesses went I would, at least up to a point, take it over. I would ask all the questions that I thought were relevant [if] I felt that the barristers were not getting out the issues that I wanted to know about. ${ }^{133}$

\footnotetext{
Interview with Participant A. Interview with Participant E. Interview with Participant A. Interview with the Honourable Ray Finkelstein QC (Melbourne, 21 November 2012). Interview with Justice David Harper (Melbourne, 19 November 2012). Interview with the Honourable Ray Finkelstein QC (Melbourne, 21 November 2012).
} 
Another participant, a Supreme Court judge, said that as a result of his experience as a barrister he 'rarely give[s] the barristers time to argue a point without intervening ${ }^{\prime}{ }^{134}$

Justice Robert McDougall reported that his experience as counsel and as a judge in major construction cases affected the way he related to counsel when managing cases: 'People know that I know the area. I know the counsel involved. ... They know, ultimately, that I am going to get my way.' ${ }^{135}$ This, combined with a preparedness to 'discuss', 'listen and change and adapt a procedural solution into which everyone's had input' enabled McDougall to achieve agreement between parties to mega-litigation, rather than imposing procedures on unwilling parties. ${ }^{136}$

This section has provided examples of the ways in which participants' experience of complex litigation as lawyers improved their ability to deal with mega-litigation as judges. There may be further examples to which participants did not allude. The important point is that a significant proportion of participants found that the experience they brought to the bench gave them tools for dealing with megalitigation which they would not otherwise have possessed.

There is a potential downside to judges bringing litigation experience to the bench. While extensive experience in complex litigation may equip judges with skills and understanding to help them manage mega-litigation, it may also equip them with bad habits. At several points in this thesis, I have identified a number of ways in which the culture of the legal profession contributes to the problem of megalitigation. In Chapter 4 I identified the adversarial culture of the legal profession as a cause of mega-litigation. ${ }^{137}$ In Chapter 9 I comment on the tendency of lawyers to swamp the court with marginally relevant documents ${ }^{138}$ and to resist innovations such as new uses of technology. ${ }^{139}$ Judges appointed from the ranks of commercial barristers and solicitors are steeped in the culture of the profession. Some judges (and the majority of interview participants appeared to fall into this category) will reflect critically upon their experience in the profession and use this experience to improve the way litigation is run. Others, we can expect, might continue to do

\footnotetext{
$134 \quad$ Interview with Participant D.

135 Interview with Justice Robert McDougall (Sydney, 6 June 2012).

136 Ibid.

137 At 54-6.

138 At 175-8. See also Justice Kenneth Hayne, 'The Vanishing Trial' (Paper delivered at Supreme and Federal Courts Judges Conference, Sydney, 23 January 2008), 19-20 (quoted in Chapter 4 at 50-1). 
things as they have always done them. This highlights the influence of personality, as well as experience, in shaping the way that judges deal with mega-litigation. A judge who comes to the bench with experience in complex litigation, but without the creative, active, flexible outlook explored in this chapter is not likely to manage mega-litigation in an efficient manner.

\section{CONCLUSION}

This chapter has identified four characteristics of the mega-litigation judge that permeate virtually every aspect of their role. The mega-litigation judge is not the old-fashioned cuckoo clock judge. Mega-litigation judges are highly engaged participants in litigation from its earliest stages; they mould procedures to suit the needs of each case; they make up rules as they go along. Involvement and imagination, rather than the passive application of rules, are the hallmarks of the mega-litigation judge.

In Chapter 2, I introduced the notion that civil procedure has multiple aims: justice for the parties and the public; and efficiency for the parties and the public. The characteristics of the mega-litigation judge explored in this chapter reflect the pursuit of these multiple aims. The mega-litigation judge is not concerned solely with doing justice between the parties. They are keenly aware of the effect of megalitigation on the court system as a whole, and are willing to pursue efficiency through aggressive, innovative case management. On the other hand, participants displayed a strong concern for procedural fairness - an aspect of justice between the parties.

This thesis asks how judges, in mega-litigation, reconcile the aims of efficiency and justice. This chapter has taken us some way towards answering this question. The judicial response to the challenges of mega-litigation has not been to prioritise efficiency over justice (or vice versa) but instead to seek better ways of handling these cases. By embracing novel solutions to the challenges of mega-litigation, judges look for ways of improving efficiency without compromising justice between the parties. As explained in Chapter 2, ${ }^{140}$ the various aims of civil procedure are not necessarily antagonistic to one another. The active, creative and flexible approach put forward in this chapter appears to reflect a conviction that courts need not accept enormous inefficiency as the price of doing justice between the parties to megalitigation.

$140 \quad$ At $23-4$. 
Reconciling the various aims of civil procedure in this way is possible only if we reject the idea that party control is an aspect of justice between the parties: that is, if we conceive of 'justice between the parties' as resolving the real issues between the parties, rather than allowing the parties to run the case as they see fit. ${ }^{141}$ The characteristics of the mega-litigation judge discussed in this chapter are consistent with the broader trends, in civil procedure, towards case management and court (rather than party) control of litigation. ${ }^{142}$

In the following chapter, we continue our exploration of the task of the megalitigation judge at a lower level of abstraction. The chapter will provide an overview of the range of procedural techniques that judges use in mega-litigation. This will demonstrate the way in which the attitudes and approaches introduced in this chapter manifest themselves in practical situations, providing concrete examples of the ways in which mega-litigation judges seek to reconcile justice and efficiency. These examples will demonstrate that the multiple aims of civil procedure efficiency and justice for the public as well as for the parties - are constantly at play as judges make choices about how to manage mega-litigation. We will see the creative, flexible techniques that judges use in an effort to improve efficiency without compromising justice.

\footnotetext{
141 This conception of justice was introduced in Chapter 2 of this thesis at 15.

$142 \quad$ See generally Chapters 6 and 7.
} 


\section{Chapter 9: Procedural TechniQues in Mega-Litigation}

\section{INTRODUCTION}

Courts face a choice. Either they can remain supine in the face of the challenges presented by mega-litigation or they can respond creatively to those challenges. ${ }^{1}$

The previous chapter explored judges' general approach to mega-litigation. I identified four attributes that characterise this approach: the mega-litigation judge is active, creative, flexible and fair. It followed that their response to the dilemma of how to reconcile the aims of justice and efficiency was likely to involve looking for new, better ways of handling mega-litigation efficiently while still affording the parties a fair hearing. The current chapter focuses on the ways in which these ideas are put into practice.

This chapter examines some of the procedural techniques that Australian courts and judges use to deal with mega-litigation. Qualitative interview data is supplemented by published decisions, speeches, articles, books and practice guides. ${ }^{2}$ This chapter outlines the procedural techniques used in mega-litigation that emerged most strongly from the interviews and other sources. In particular, I consider case management by a single judge; management of discovery; judicial control over the structure of the trial; separate determination of issues; sharing the judicial task with other officers; methods of dealing with evidence, and control of the way in which legal argument is delivered. I also examine the use of technology in mega-litigation, and the dynamics of the relationship between the judge, the lawyers, and the parties.

The primary aim of this chapter is to record the techniques that judges use in megalitigation, rather than arguing that particular techniques are preferable. Nor is this chapter a manual for procedure in mega-litigation. ${ }^{3}$ By inquiring into how mega-

$1 \quad$ Acting Justice Ronald Sackville, 'Mega-Litigation: Towards a New Approach' (2008) 8 The Judicial Review 89, 89.

2 The method of combining empirical data with other sources is known as 'triangulation' and is commonly used in qualitative research: see Jane Lewis and Jane Ritchie, 'Generalising from Qualitative Research' in Jane Ritchie and Jane Lewis (eds), Qualitative Research Practice (Sage Publications, 2003) 263, 276-6; Michael Quinn Patton, Qualitative Research and Evaluation Methods (Sage Publications, $3^{\text {rd }}$ ed, 2002) 247-8.

3 Publications along these lines already exist, although they are necessarily in the nature of guidelines rather than prescriptive rules: Judiciary of England and Wales, Report and Recommendations of the Commercial Court Long Trials Working Party (December 2007); Class Action and Electronic Trial Guide, Federal Court of Australia (2012) (Copy on file with author); Federal Judicial Center, Manual for Complex Litigation, Fourth (2004); Michael Legg, Case Management and Complex Civil Litigation (Federation Press, 2011). 
litigation judges go about their task, this chapter will add content to some concepts which have, until this point, been discussed at a higher level of abstraction. In Chapter $8 \mathrm{I}$ introduced the active, creative, flexible and fair approach of the megalitigation judge. In the current chapter I show how this approach translates into the day-to-day work of handling mega-litigation.

While the aim of this chapter is positive rather than normative, the analysis does reveal strong support for some techniques. For instance, there was a strong view that management of a mega-litigation case by a single judge is crucial, and many participants had used similar techniques in controlling discovery and structuring trials. While the limits of the qualitative method employed in this study must be kept in mind, ${ }^{4}$ the analysis in this chapter does suggest that some practices are desirable, at least from the point of view of the court.

\section{DOCKET SYSTEMS}

As explained in Chapter $8,^{5}$ active case management is one of the keys to dealing with mega-litigation. For many interview participants, ${ }^{6}$ the efficacy of intensive case management depended on the existence of a docket system: that is, a system under which each case is managed by a single judge from commencement through to judgment. The docket system is standard practice in the Federal Court, ${ }^{7}$ and modified docket systems are used in other jurisdictions. ${ }^{8}$ There are several clear benefits in a single judge managing a mega-litigation case throughout the life of the matter. The judge is able to become familiar with the facts, issues, documents and personnel in the case. This saves court time, as the judge does not have to become familiar with a gigantic file for the first time at every hearing; they simply need to keep 'up to speed' with new developments. ${ }^{9}$ In addition, a judge who is familiar

These limits are discussed in Appendix A.

At 132-9.

Interview with the Honourable Ray Finkelstein QC (Melbourne, 21 November 2012); Interview with the Honourable Malcolm Lee QC (Fremantle, 6 March 2013); Interview with Chief Justice Wayne Martin (Perth, 6 March 2013); Interviews with Participants D, E, F and G.

$7 \quad$ Federal Court of Australia, Practice Note CM1 - Case Management and the Individual Docket System, 1 August 2011.

$8 \quad$ See, eg, Supreme Court (Miscellaneous Civil Proceedings Rules) 2008 (Vic) O 2; Supreme Court of Victoria, Practice Note No 10 of 2011 - Commercial Court; Court Procedures Rules 2006 (ACT) r 1402; Supreme Court of Queensland, Practice Direction No 11 of 2012 - Supervised Case List; Supreme Court of Queensland, Practice Direction No 3 of 2002 - Commercial List; Supreme Court Civil Rules 2006 (SA) r 115; Supreme Court of South Australia, Supreme Court Practice Directions 2006, Direction 5.1; Rules of the Supreme Court 1971 (WA) O 4A Div 3; Supreme Court of Western Australia, Consolidated Practice Directions 2009, Direction 4.1.2.

9 Interview with Participant D. Chief Justice Wayne Martin made a similar point: Interview with Chief Justice Wayne Martin (Perth, 6 March 2013). 
with a matter is able to play a more 'constructive role'10 in guiding the direction of the matter. Writing extrajudicially, Justice Steven Rares of the Federal Court explained that the docket system

enables the judge to become familiar with the issues, to help the parties refine them, to ensure that the case is properly managed so that it will be presented at trial in the way that it is most likely to achieve an efficient presentation of the real issues in dispute and their speedy determination. ${ }^{11}$

In practice, the pre-trial management of a mega-litigation is almost always allocated to a single judge. Under some modified docket systems, however, a different judge may hear the trial. ${ }^{12}$ This may also happen if the case managing judge is disqualified from hearing the trial because of apprehended bias or a conflict of interest ${ }^{13}$ or when a case is transferred from another court after being on foot for some time. ${ }^{14}$

Several interview participants said it was desirable for the case managing judge to hear the trial. The prospect of trial before the same judge could affect the parties' behaviour, as Chief Justice Wayne Martin explained:

The big advantage I think of the case manager who is also the trial judge is that it keeps the parties honest. Because they don't want to antagonise you and they don't want you to form an impression that they're playing strategic games because they know that will influence your attitude towards their case at trial. So I think being the trial judge is a big advantage as case manager. It's a disadvantage if you're not. ${ }^{15}$

Another participant made a similar point:

You're the one that's going to hear it and you know it and they know it. And that's why ... waffling with false issues doesn't work with a docket judge,

10 Interview with the Honourable Malcolm Lee QC (Fremantle, 6 March 2013).

11 Justice Steven Rares, 'What is a Quality Judiciary?' (2011) 20 Journal of Judicial Administration 133, 142. For further discussion of the benefits of docket systems, see Caroline Sage and Ted Wright with Carolyn Morris, Case Management Reform: A Study of the Federal Court's Individual Docket System (Law and Justice Foundation, June 2002) 48-51.

12 See, eg, Supreme Court of South Australia, Supreme Court Practice Directions 2006, Direction 5.1.1.

13 The $C 7$ and Centro mega-litigation trials were both allocated to their ultimate trial judges partway through their history, as conflicts arose for the judges originally allocated.

14 For example, the Bell Group proceedings had been on foot for more than four years, managed by Carr J in the Federal Court, before being transferred to the Supreme Court of Western Australia. See Bell Group Ltd v Westpac Banking Corporation (2000) 104 FCR 305. Interview with Chief Justice Wayne Martin (Perth, 6 March 2013). 
because the parties know they'll get the judge offside if they put up things that are a waste of time. ${ }^{16}$

One participant said it was important to keep in mind that the docket system has advantages for the parties as well as for the court system:

The average cost of an appearance at a directions hearing ... is ... per party ... between $\$ 20,000$ and $\$ 30,000$. That is huge. ... From my perspective that means each party has invested $\$ 20,000$ or $\$ 30,000$ in me. In the Court. That is, imparting to the Court some knowledge that they think is important. Either because they want a dispute resolved in order to progress the litigation or ... sometimes it's just to educate me. Sometimes it's just, you know, 'we need to get together and work out where we're at, what's happening, and get everyone in the room at one time.' I think it has to be one person from the beginning all the way through. Because otherwise the investment's lost. ${ }^{17}$

Support for the docket system was not unanimous. One participant, a Supreme Court judge, said that while the docket system worked well in the Federal Court the system would not be practicable in a jurisdiction with a heavier and more varied caseload. ${ }^{18}$ The same participant said a docket system could undermine the uniformity of case management across the court, with the quality of the management of each case depending on the judge to whom it is randomly allocated. ${ }^{19}$ These are concerns about the working of a random-allocation docket system across the court as a whole, rather than objections to the continuous management of a case by one judge. However, the observation that the efficacy of the docket system varies according to the judge handling each case highlights the weakness of a system that relies on the competence and engagement of individual judges. ${ }^{20}$ The system will work well insofar as its constituents are highly active, hard-working and committed to achieving efficiency. If, however, some judges within the system are less committed to the pursuit of efficiency - either because of laziness or because of a fundamentally different view on the aims of civil procedure - the system offers little incentive for those judges to change their ways.

No participant said management of a mega-litigation matter by one judge was undesirable. It seems that, in order for mega-litigation to be managed efficiently, it is

\footnotetext{
16 Interview with Participant F.

17 Interview with Participant E.

18 Interview with Participant A.

19 Similar concerns have been expressed elsewhere: Australian Law Reform Commission, Review of the Federal Civil Justice System, Discussion Paper No 62 (1999) 295 [10.61]; Sage, Wright and Morris, above n 11, 23, 107-11. 
not enough for the matter to be allocated to a single judge; it must be allocated to the right judge: one with the active, creative, flexible and fair approach described in the previous chapter.

\section{DISCOVERY}

The amount of time and money consumed by discovery is often cited as one of the biggest problems with modern litigation. ${ }^{21}$ Courts are constantly attempting to reduce the cost and time associated with discovery. For example, the Federal Court reformed its discovery processes in 2011. Discovery is no longer automatically given; a party who wants discovery must apply to the Court, and the Court has extensive powers to limit, control and supervise the process. ${ }^{22}$ In 2012, the Equity Division of the Supreme Court of New South Wales introduced a Practice Note stipulating that there would be no order for discovery until the parties had served their evidence. ${ }^{23}$

The problems of discovery are magnified in mega-litigation because of the breadth of the factual issues involved, the resources that the parties are prepared to expend, and the 'battlefield mentality' ${ }^{24}$ with which mega-litigation is often conducted. The management of discovery in mega-litigation has been an area in which judges have been willing to be particularly active and creative. There are many ways in which discovery can be controlled. ${ }^{25}$ Two interview participants described their techniques for handling discovery in mega-litigation. The Honourable Ray Finkelstein QC, while not a proponent of setting formal categories of discoverable documents, 'would work out with the parties' the categories of documents that were likely to be most useful. Based on the issues in the case and relying on his experience as a

21 See, eg, Australian Law Reform Commission, Managing Discovery: Discovery of Documents in Federal Courts, Report No 115 (2011); Australian Law Reform Commission, Managing Justice: A Review of the Federal Civil Justice System, Report No 89 (2000), [7.178]; Federal Court of Australia, Case Management Handbook (13 October 2011), 32 [7.4]; Justice Peter Vickery, 'Managing the Paper: Taming the Leviathan' (2012) 22 Journal of Judicial Administration 51.

$22 \quad$ See Federal Court Rules 2011 (Cth) pt 20 div 2; Federal Court of Australia, Practice Note No CM 5 - Discovery, 1 August 2011.

23 Supreme Court of New South Wales, Practice Note SC Eq 11 - Disclosure in the Equity Division, 22 March 2012.

24 Interview with Justice Robert McDougall (Sydney, 6 June 2012). See further in Chapter 3 at 546.

25 The US Federal Judicial Center's Manual for Complex Litigation, Fourth (2004) identifies time limits, limits on quantity, phased, sequenced or targeted discovery, subject-matter priorities, and sequencing by parties as ways in which discovery could be limited in a given case: at [11.422] 53-5. 
commercial lawyer, as well as the input of the parties, Finkelstein would determine where the most important documents were likely to be found:

I would look at the issues and say 'look, the first thing you can do is get a particular category of all the Board papers and nothing else. When you have looked at those and you need more come back in a few weeks' time'. ${ }^{26}$

If the parties reported that the first category of documents did not furnish them with sufficient information, Finkelstein would redirect the search, again focusing on the area which was most likely to yield documents bearing on the crucial issues:

I would ask the parties for example, 'did the Board have a subcommittee or was a specific officer designated to deal with this issue in dispute?' And if the answer was 'yes' I would then know where to look.' So, those documents would be produced ... And then the parties could come back and have another go and see what they need next. ${ }^{27}$

Wayne Martin spoke about the challenges of discovery in an age when technology makes it possible to retrieve electronic documents 'indiscriminately':

There is a real danger of ... discovery by avalanche of material, which then means that if there is a smoking gun ... you can hide it in three million documents that you discover. ${ }^{28}$

Martin said he would not contemplate an order for general discovery in megalitigation. Instead, in a recent mega-litigation matter, he had convened a series of round-table discovery conferences. The parties were able to bring to the conference their consultants responsible for managing their electronic document databases. At these conferences, the parties and the judge reached agreement on 'the basic parameters of the process'. Discovery of electronic documents was to be based on agreed search terms entered into the databases. Like Finkelstein, Martin would wait to see what this process produced before, if necessary, ordering further discovery based on additional search terms.

Another participant spoke of ordering the parties to exchange 'critical documents' and then determining whether further discovery was necessary. ${ }^{29}$

There are some common threads in these techniques. They require substantial input from the judge; input based on an understanding of the critical issues in the case,

\footnotetext{
26 Interview with the Honourable Ray Finkelstein QC (Melbourne, 21 November 2012).

$27 \quad$ Ibid.

28 Interview with Chief Justice Wayne Martin (Perth, 6 March 2013).

29 Interview with Participant F.
} 
and of the sort of documents which might be relevant to those issues. They involve detailed attention to the circumstances of each case, rather than the application of general rules. As such, these techniques are illustrations of the active, flexible, creative approach introduced in the previous chapter. They also tell us something about the respective roles of the parties and the judge. It is not up to the parties to decide what documents they wish to include; it is the responsibility of the judge to work out, in collaboration with the parties, what documents are needed in order to do justice in the case. This need not involve the judge dictating what the parties do; the processes that participants described were collaborative rather than dictatorial.

These techniques are all aimed at reducing the scale of discovery while ensuring that the key documents are exchanged, so that the utility of the discovery process to the resolution of the real issues is not compromised. This reflects another point made in Chapter 8: judges are dealing with mega-litigation not by compromising justice for efficiency but by taking control of litigation from the parties, and by employing innovative methods.

\section{SEPARATE ISSUES}

A huge case can be easier to manage if broken down into smaller parts. Dealing with discrete issues separately may enable mega-litigation to be disposed of relatively efficiently without any compromise of justice between the parties. If there is a discrete issue which, if decided a particular way, will be determinative of the whole action, or will increase the chances of settlement, it may be appropriate to determine that issue before proceeding with the rest of the case. ${ }^{30}$ For example, it sometimes makes sense to have a trial and judgment on the issue of liability before a trial on the issue of quantum of damages. In C7, Sackville J noted that such a course might, with hindsight, have been appropriate: as the plaintiffs were wholly unsuccessful on the question of liability, the time spent on the question of damages had been wasted. ${ }^{31}$

30 The court rules in most jurisdictions expressly allow for the determination of separate issues: Court Procedures Rules 2006 (ACT) Div 2.15.3; Federal Court Rules 2011 (Cth) Div 30.1; Uniform Civil Procedure Rules 2005 (NSW) pt 28; Supreme Court Rules (NT) r 47.04; Uniform Civil Procedure Rules 1999 (Qld) Ch 13 Pt 5; Supreme Court Civil Rules 2006 (SA) r 211; Supreme Court Rules 2000 (Tas) r 559; Supreme Court (General Civil Procedure) Rules 2005 (Vic) rr 47.04, 47.05; Rules of the Supreme Court 1971 (WA) O 32 r 5. For an example of the criteria that can be applied to determine whether severance of issues is appropriate, see Federal Court of Australia, Case Management Handbook, above n 21, 28 [5.78]-[5.82]. 
The High Court has, from time to time, warned of the dangers of trying separate issues. In Tepko Pty Ltd $v$ Water Board, ${ }^{32}$ Kirby and Callinan JJ cautioned:

The attractions of trials of issues rather than of cases in their totality, are often more chimerical than real. Common experience demonstrates that savings in time and expense are often illusory, particularly when the parties have ... had the necessity of making full preparation and the factual matters relevant to one issue are relevant to others, and they all overlap. ${ }^{33}$

Those interview participants who were enthusiastic about the trial of separate issues were aware of the High Court's position, ${ }^{34}$ and acknowledged the pitfalls associated with trying separate issues. For one thing, separate questions sometimes 'take on a life of their own'; 35 the determination of the question by the trial judge can be appealed, thus delaying the action for months or years and, if the appeal succeeds, rendering the original determination nugatory. ${ }^{36}$ For another, in complex litigation the issues may be so intertwined that it is impossible to isolate a truly discrete issue. ${ }^{37}$ Further, High Court authority makes it clear that, at least in Federal courts, determinations of separate issues must be based on an established or agreed set of facts. ${ }^{38}$ Once again, interview participants were aware of this requirement. ${ }^{39}$ In hard-fought, factually dense mega-litigation, it may be very difficult to reach agreement about the facts that will form the basis of the separate determination. ${ }^{40}$ Having to engage in an extensive process of finding contested facts may negate the benefits of the separate issue procedure. Finally, there was the possibility that trying a preliminary issue separately may not yield the desired benefits. One Federal Court

32 (2001) 206 CLR 1.

33 Ibid 55 [168]. Gaudron J agreed with these remarks: at 18 [52]. See comments to similar effect in Perre v Apand Pty Ltd (1999) 198 CLR 180332 [436] (Callinan J); New South Wales v Lepore (2003) 212 CLR 511, 578 [187] (Gummow and Hayne JJ); Waterways Authority v Fitzgibbon (2005) 79 ALJR 1816, 1822 [37] (Kirby and Heydon JJ).

34 Robert McDougall said there was an 'enormous bias' in Australia against dealing with separate issues: Interview with Justice Robert McDougall (Sydney, 6 June 2012).

35 Interview with Participant A. Participant G expressed similar concerns.

36 See, eg, IOOF Australia Trustees Ltd v Seas Sapfor Forests Pty Ltd (1999) 78 SASR 151; Tepko Pty Ltd $v$ Water Board (2001) 206 CLR 1, 55 [170] (Kirby and Callinan JJ).

$37 \quad$ See, eg, Idoport Pty Ltd v National Bank Ltd [2000] NSWSC 1215; Legg, above n 3, 82.

38 Bass v Permanent Trustee Co Ltd (1999) 198 CLR 334. In Bass, a procedure adopted by the Federal Court was held to be in breach of Chapter III of the Constitution. The procedure involved the determination of a question reserved, on the basis of a bundle of documents which provided general background information, but in the absence of any agreed or established facts.

39 Interviews with Participants A and G.

40 Particularly since, as one participant pointed out, determination of a separate issue is of little use unless the parties are prepared to agree the underlying facts for all purposes in the trial: Interview with Participant A. 
judge presiding over a major, multi-issue case decided to hear one issue before the balance of the trial:

I was told by counsel that that was a really good idea because they thought that if the ... question was resolved the rest would go away. And it just didn't. And I don't know what happened and of course I can't ask. But I think in retrospect it would have been much easier if I'd just done the whole thing. ${ }^{41}$

All these concerns relate to the design and operation of the separate issue procedure in particular cases, rather than being fundamental problems with the procedure itself. Most of the concerns can be overcome by very careful attention to the appropriateness of an issue for separate determination, the form of the question to be separately determined, and the factual basis on which it is to be determined. All of this requires a high level of judicial engagement with the issues, the facts, and the manner by which the facts are to be proved. It also calls for co-operation from the parties. Robert McDougall described the circumstances in which he had decided to determine a preliminary question (on the right to terminate a contract) in a megalitigation matter: ${ }^{42}$

I was encouraged ... in this particular case to take an innovative approach to separation of questions, and to try and break loose of the traditional shackles. ... The parties were not unwilling to do that. It wasn't a question of my forcing a regime on them, so the prospects of appellate interference are not all that high. ${ }^{43}$

Despite its difficulties, there is some judicial enthusiasm for the separate issue procedure. In 1995, Smith J in the Victorian Court of Appeal observed that the procedure was capable of yielding 'spectacular' benefits that 'far outweigh the disadvantages that arise when occasionally such an attempt is not successful.' ${ }^{44}$ Several interview participants reported using this technique successfully. ${ }^{45}$ Two participants identified the separation of issues as a key area of development in the management of mega-litigation. ${ }^{46}$ Robert McDougall explained how the process could both alleviate the burden on the judge, and facilitate settlement:

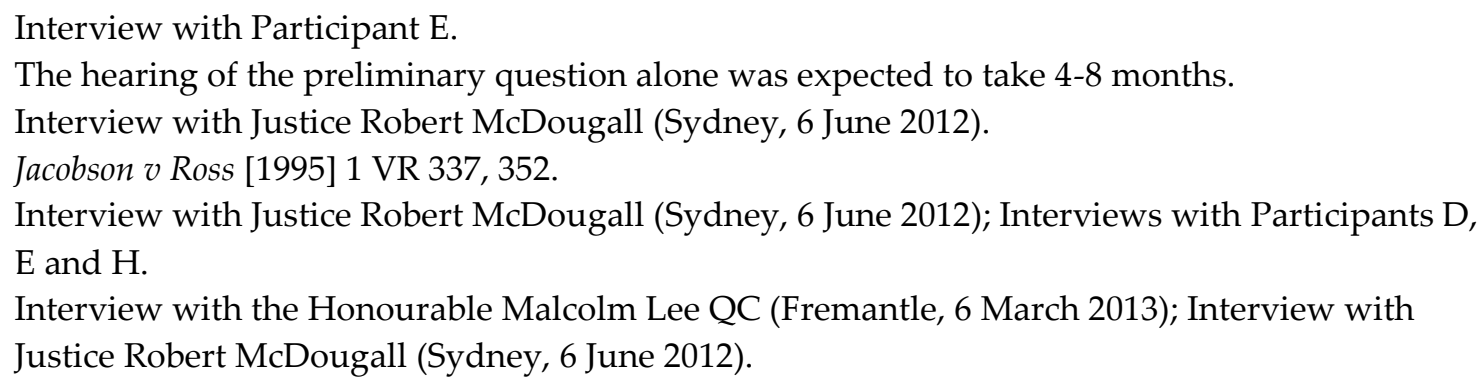


I think we do need to re-evaluate our whole approach to the separation of questions, because I don't think mega-litigation is going to go away. And I don't think it's going to get any easier to handle. And I do think ... that it can get to a stage where ... it's just too much to take in. So if you can find a way of staging the hearing, you lessen the burden. And you also make it easier for the parties then to see what their real prospects are - they've had a judicial determination on [an issue]. They might or might not agree. ... But the losing party knows that at least one independent mind has a different view. ${ }^{47}$

The Honourable Malcolm Lee QC also thought a 'more relaxed' attitude ought to be taken to the determination of separate issues in mega-litigation. He explained that the value of this process did not lie only in the possibility that a single issue could be dispositive of the entire matter:

It [can] also help counsel to chart how to prepare thereafter, even if they intend to challenge that finding later, it might be that they would, having had it go against them on a preliminary issue, [prepare differently]. ... It might have quite a bearing on how they prepare the case, and present it....

In big trials there's always going to be something that may be sitting in there, there will always be a kernel that would be worthwhile dealing with because of the ramifications that it can have for other things. Not because it determines the matter ... but because it has the ability to change the complexion of the litigation. ${ }^{48}$

The trial of separate issues, then, is one way of making mega-litigation more efficient while still determining the key issues between the parties. While the High Court's warnings about the dangers of this process have been heeded, there is potential for this process to be used more extensively in the future. In order to be effective, it requires a high level of commitment and attention from both the parties and the judge. This calls for many of the skills and attributes of the mega-litigation judge identified in the previous chapter: active case management, creativity and flexibility as well as experience and understanding of complex litigation.

\section{SHARING THE JUDICIAL TASK}

There are other ways in which judges can break a mega-litigation matter into smaller sections. One possibility is to pass tasks on to other people. Some procedural applications can be heard by an officer of the court such as a Master, Associate Judge or Registrar, thus reducing the workload on the case managing judge. This need not undermine the docket system. Officers of the court are generally used to deal with

$47 \quad$ Interview with Justice Robert McDougall (Sydney, 6 June 2012).

48 Interview with the Honourable Malcolm Lee QC (Fremantle, 6 March 2013). 
routine procedural applications, with the docket judge retaining responsibility for the ongoing management of the matter. Two interview participants ${ }^{49}$ said that they had used such officers effectively in mega-litigation. The Honourable Neville Owen has, on several occasions, paid tribute to the contribution made by a Registrar assigned to assist with managing the logistics of the Bell Group litigation. ${ }^{50} \mathrm{He}$ explained that the Registrar would frequently meet with the parties' legal representatives 'to iron out disputes'. ${ }^{51}$ This, he said,

reduced significantly the amount of court time devoted to procedural and programming disputes that should have been routine and uncontentious but which I am aware generated some heat between the parties.

The Registrar operated effectively as a mediator. The mediations involved bringing the parties together to assist them to resolve the issues. The Registrar guided the parties in negotiating protocols and agreeing time periods in which steps were to be taken, bearing in mind general directions that I had given. This often involved negotiating extensions and truncations and the logistics of compliance. The objective of the mediations was to break down the ancillary disputes into small parts and resolve them without ever having to take them to the Judge for argument. At the end of the negotiations the Registrar was often able to make directions by consent and with the delegated authority of the Judge. 52

In addition to this case management role, the same Registrar 'helped enormously when I was writing the judgment' by 'marshalling ... documents and doing calculations and that sort of thing. ${ }^{53}$ Using other officers in this way reduces the burden on the primary judge without any compromise to justice between the parties.

Quite apart from these practical benefits, there is another reason why the case managing judge in a mega-litigation matter may decide to refer a procedural dispute to another judicial officer. This is the risk that deciding a particular interlocutory dispute may create an apprehension of bias which disqualifies the judge from continuing to hear the matter. For instance, in the ASIC $v$ Rich proceedings, a claim

49 Interview with the Honourable Neville Owen (King's Park, WA, 5 March 2013); Interview with Participant D.

50 Justice Neville Owen, 'Surpassing Sisyphus - Idle Musings on Surviving Long Trials' (Paper presented at Supreme Court of Victoria Judges' Conference, Mornington Peninsula, 5 November 2009); Owen J, 'Farewell to the Honourable Justice Neville Owen' (Retirement speech delivered at special sitting of the Supreme Court of Western Australia, 2 July 2010); Interview with the Honourable Neville Owen (King's Park, WA, 5 March 2013).

51 Owen, 'Surpassing Sisyphus', above n 50.

$52 \quad$ Ibid.

53 Interview with the Honourable Neville Owen (King's Park, WA, 5 March 2013). 
of privilege was determined by a different judge so that the trial judge, Austin J, would not have to inspect the documents over which privilege was claimed. ${ }^{54}$ To take another example, when the Centro proceedings settled mid-trial, a judge other than the trial judge heard and determined the settlement approval, because of the possibility that settlement would fail and the trial would have to proceed. ${ }^{55}$

The referee procedure offers yet another way of sharing the work of mega-litigation. In most jurisdictions, the court Rules permit the reference of a question of fact or law to a referee. ${ }^{56}$ The referee process is sometimes used in mega-litigation as a way of reducing the task of the judge without adding to the cost for the court system. Referees can be used to deal with complex technical questions involving specialised knowledge. ${ }^{57}$ The referee can be somebody outside of the court, and need not have any legal qualifications. In some jurisdictions, the referee is able to conduct a hearing in the way they see fit, and is not bound by the rules of evidence. ${ }^{58}$ In a case in which the entirety of a dispute between a builder and a sub-contractor had been referred to an architect, Gleeson CJ in the NSW Court of Appeal explained that the relative informality of the process is one of the advantages of the referee system:

Although evidence may be given orally or in writing in the same manner as evidence is given before a court, that is by no means necessarily the way in which referees conduct proceedings before them. The circumstance that referees are not bound by the rules of evidence, and may inform themselves in such a manner as they see fit, is in turn related to what is often a major part of the objective in appointing a referee. ...[T] he present case provides an illustration. No doubt part of the object in appointing an architect as referee in relation to a building dispute is often that the architect may, if appropriate, bring personal knowledge and

Australian Securities and Investments Commission v Rich [2004] NSWSC 1017.

Kirby v Centro Properties Ltd (No 6) [2012] FCA 650.

Federal Court of Australia Act 1976 (Cth) s 54A; Federal Court Rules 2011 (Cth) div 28.6; Court Procedures Rules 2006 (ACT) Div 2.15.4; Uniform Civil Procedure Rules 2005 (NSW) pt 20 div 3; Supreme Court Act (NT) ss 26-7; Supreme Court Rules (NT) O 50; Uniform Civil Procedure Rules 1999 (Qld) ch 13 pt 7; Supreme Court Act 1935 (SA) s 67; Supreme Court Rules 2000 (Tas) pt 22 div 5; Supreme Court (General Civil Procedure) Rules 2005 (Vic) O 50; Rules of the Supreme Court 1971 (WA) O 4A r 9, O 35.

$57 \quad$ See Finsbury Print Pty Ltd v CPI Graphics Ltd [2007] SASC 131, [17]-[18]; Park Rail Developments Pty Ltd v R J Pearce Associates Pty Ltd (1987) 8 NSWLR 123, 126.

$58 \quad$ See Baulderstone Pty Ltd v QIC Pty Ltd [2012] NSWSC 235, [27]-[29]; Federal Court Rules 2011 (Cth) r 28.65; Court Procedures Rules 2006 (ACT) r 1534 (referring to the Commercial Arbitration Act 1986 (ACT), especially ss 14 and 19); Uniform Civil Procedure Rules 2005 (NSW) r 20.20; cf Uniform Civil Procedure Rules 1999 (Qld) r 502(3); Supreme Court Rules 2000 (Tas) r 577, Rules of the Supreme Court 1971 (WA) O 35 r 3. Referees are generally bound by the rules of procedural fairness: Najjer v Haines (1991) 25 NSWLR 224, 228 (Kirby P), 261-2 (Rogers AJA); Xuereb v Viola (1989) 18 NSWLR 453. 
experience to bear. Referees do not operate under the same constraints as judges in relation to the limitations upon the use they make of personal knowledge. ${ }^{59}$

Once the hearing is complete, the referee produces a report recording their conclusions on questions of fact and law. ${ }^{60}$ The Court may choose to adopt or reject all or part of the report. ${ }^{61}$ Importantly, the parties - rather than the court system are generally responsible for the remuneration of the referee, and associated costs. ${ }^{62}$

Three interview participants spoke favourably of the use of the reference process in mega-litigation. ${ }^{63}$ Robert McDougall had referred a question of building defects to a referee, expecting that, although the referee might take many months to complete the task, this would be much more efficient than having a judge decide the issues:

Classic question for referee: not bound by the rules of evidence, can invent their own procedures, can sit in the room with experts and reach a view et cetera et cetera et cetera. Much more efficient than having a judge do it. ${ }^{64}$

Justice Peter McClellan saw the expansion of the reference procedure as a key area of growth in the management of mega-litigation:

I think that we will increasingly develop [the reference] process and require more and more cases to be dealt with ... in that way. Which means the parties fund the venue, fund the decision-maker, and fund the litigation themselves. Now if that was to happen, that will in part impose its own discipline on the cases, because it will become more expensive. If you've got to fund the court structure, the shorthand writer, and the decision-maker, that's a much bigger bill. It's a costshifting move, but it seems to me to be an entirely legitimate cost-shifting move. ${ }^{65}$

Super Pty Ltd v SJP Formwork (Aus) Pty Ltd (1992) 29 NSWLR 549, 557.

$60 \quad$ Federal Court Rules 2011 (Cth) r 28.66; Court Procedures Rules 2006 (ACT) r 1536; Uniform Civil Procedure Rules 2005 (NSW) r 20.23; Supreme Court Rules (NT) r 50.03; Uniform Civil Procedure Rules 1999 (Qld) r 504; Supreme Court Rules 2000 (Tas) r 575; Supreme Court (General Civil Procedure) Rules 2005 (Vic) r 50.03.

$61 \quad$ Federal Court of Australia Act 1976 (Cth) s 54A(3); Federal Court Rules 2011 (Cth) r 28.67; Court Procedures Rules 2006 (ACT) r 1537; Uniform Civil Procedure Rules 2005 (NSW) r 20.24; Uniform Civil Procedure Rules 1999 (Qld) r 505; Supreme Court Act 1935 (SA) s 67(3); Supreme Court (General Civil Procedure) Rules 2005 (Vic) r 50.04; Rules of the Supreme Court 1971 (WA) O 35 rr 89.

62 See Court Procedures Rules 2006 (ACT) r 1538; Uniform Civil Procedure Rules 2005 (NSW) r 20.18; Supreme Court Rules (NT) r 50.06; Uniform Civil Procedure Rules 1999 (Qld) r 506; Supreme Court Act 1935 (SA) s 67(4); Supreme Court (General Civil Procedure) Rules 2005 (Vic) r 50.06.

63 Interview with Justice Peter McClellan (Sydney, 5 June 2012); Interview with Justice Robert McDougall (Sydney, 6 June 2012); Interview with Participant A.

64 Interview with Justice Robert McDougall (Sydney, 6 June 2012).

65 Interview with Justice Peter McClellan (Melbourne, 5 June 2012). 
Taking evidence on commission offers another, less drastic, method of reducing the judge's task in mega-litigation. This process, which has its roots in 18th-century Chancery practice, ${ }^{66}$ traditionally involved a court-appointed examiner taking the evidence of a witness outside the jurisdiction. Evidence taken in this manner could be adopted by the Court as evidence in the case. The process was later expanded to allow an examiner to take evidence of a witness who was within the jurisdiction but unable to attend the hearing. ${ }^{67}$ In mega-litigation the process has been taken further. In the ultimately abortive Idoport proceedings $s^{68}$ - a clear case of mega-litigation Einstein J took the 'very unusual step' of ordering that the cross-examination of some of the expert witnesses be taken by an examiner. ${ }^{69}$ In taking this step, Einstein J was motivated by efficiency concerns:

There is simply such a huge saving of time capable of being achieved by the proposal for cross-examination even of some ... witnesses before an examiner, that to my mind the adoption of this course represents a practicable and efficient case management procedure for the taking of a particular category of evidence. The proposal serves the dual purposes of ensuring that the trial judge be freed to hear other cases and to carry out chamber work in relation to the ongoing proceedings, as and when practicable during what, save for an examiner presiding over the taking of certain cross-examination evidence, would arguably have taken up ... a considerable section of the trial judge's time sitting in court. ${ }^{70}$

In reaching this decision, Einstein J referred to the 'overriding purpose' in the Court Rules of facilitating the 'just, quick and cheap resolution of the real issues' in proceedings. ${ }^{71}$ His Honour also invoked the aims of public justice and public efficiency, referring to the 'public interest' in avoiding a situation in which 'certain litigants [consume] hugely disproportionate amounts of scarce judicial resources, the principle being an effort to allocate court time evenly amongst litigants. ${ }^{72}$ In the unusual circumstances of a very long and complex case, he emphasised that judges

66 See Gummow J's discussion of the history of the process in Elna Australia Pty Ltd v International Computers (Aust) Pty Ltd (1987) 14 FCR 461, 466, referring to Moodalay v Morton (1785) 1 Br C C 469; 28 ER 1245; Lord Belmore v Anderson (1792) 2 Cox 288; 30 ER 134; Thorpe v Macauley (1820) 5 Madd 218; 56 ER 877; Devis v Turnbull (1822) 6 Madd 232; 56 ER 1080.

$67 \quad$ See Warner $v$ Mosses (1880) 16 Ch D 100; Bidder v Bridges (1884) 26 Ch D 1.

68 The proceedings were dismissed, after more than 200 days of trial, when the plaintiff failed to provide security for costs: Idoport Pty Ltd v National Australia Bank Ltd [2002] NSWSC 18.

$69 \quad$ Idoport Pty Ltd v National Australia Bank Ltd [2001] NSWSC 838, [12].

70 Ibid [101].

71 Ibid [15]-[17], [19], referring to Supreme Court Rules 1970 (NSW) pt 1 r 3 . See the discussion of overriding purpose provisions in Chapter 7.

72 Idoport Pty Ltd $v$ National Australia Bank Ltd [2001] NSWSC 838, [89]. See also [83]-[88], in relation to the 'public interest' aspect of case management. 
should be prepared to exercise their discretion to adopt unconventional procedures in order to reduce the burden on the court system. ${ }^{73}$

Sharing the judicial task with masters, referees or commissioners is not a new idea; these procedures have a long history. But it seems that mega-litigation judges are open to using these procedures more often than they have been used in the past, in order to reduce the burden on a single judge, and to improve efficiency. This is another area in which judges have responded creatively to the challenges of megalitigation.

Some judges have taken the idea of sharing the judicial task even further, suggesting that an entire mega-litigation matter (including the trial) could be heard by a panel of two or more judges. ${ }^{74}$ Neville Owen has been one of the most vocal proponents of this idea. In the Bell Group judgment he recommended that

a panel of judges should be allocated to hear and decide cases of unusual length and complexity. I have no doubt that had two judges been hearing this action it would have occupied much less than half the time. ${ }^{75}$

In an interview for the purpose of this project, Owen explained two ways in which a panel of judges would have saved time:

One is that if you've got a problem and you're nutting it out by yourself it might take you a day to come up with the answer. If you've got to talk about it to someone else, the mere ... discipline of having to put your thoughts in order so that you can tell someone about them and get their feedback, [will mean that] what would otherwise have been a day will only be half an hour. But the other thing is that these sorts of cases lend themselves to be split up. ... In Bell, I saw how you could have split it up. Judge A deals with that, Judge B deals with this, Judge $C$ deals with this, you video it so that if an issue comes up the other judges ... can have a look at the video. You then of course take joint responsibility for the judgment. ${ }^{76}$

In the $C 7$ judgment, Sackville J championed the idea of employing either a panel of judges, or a 'reserve judge' in mega-litigation. ${ }^{77}$ The benefits would be similar to those identified by Owen J: there would be 'a division of labour and an opportunity

73 Ibid [4]-[11], [103]-[108].

$74 \quad$ Bell Group Ltd (in liq) v Westpac Banking Corporation (No 9) (2008) 39 WAR 1, 903 [9736] (Owen J);

Rares, 'What is a Quality Judiciary?', above n 11, 143; Judiciary of England and Wales, above $n$

3, 60 [168].

75 Bell Group Ltd (in liq) v Westpac Banking Corporation (No 9) (2008) 39 WAR 1, 903 [9736].

76 Interview with the Honourable Neville Owen (King's Park, WA, 5 March 2013).

77 Seven Network Ltd v News Ltd [2007] FCA 1062, [66]. 
for discussion between peers on the complex issues thrown up by mega-litigation. ${ }^{78}$ In addition, Sackville J pointed out that it would alleviate the risk that, were one judge unable to complete the trial, the trial would have to start afresh before a new judge. ${ }^{79}$

Several interview participants thought a panel of judges had the potential to make mega-litigation progress more quickly, and to lessen the burden on any one judge..$^{80}$ This would not be appropriate in every case; in ASIC $v$ Rich, Austin J dismissed any suggestion that it would have been helpful to have more than one judge involved in the hearing, because 'the factual ... issues were integrated and needed to be mastered by a single mind.' ${ }^{81}$ One interview participant foresaw 'logistical and administrative issues' but nonetheless thought that 'a panel of judges is an initiative worth seriously considering in future. ${ }^{\prime 82}$ The biggest obstacle to any proposals to have megalitigation heard by multiple judges, however, is resources. Most of those participants who saw benefits in the panel-of-judges proposal acknowledged that allocating more than one judge to be devoted to a single matter may increase, rather than alleviate, the strain on court resources..$^{83}$

\section{STRUCTURING THE TRIAL}

Traditionally, an adversarial trial follows a conventional pattern. ${ }^{84}$ The plaintiff begins with their opening address and then presents their evidence by tendering documents and calling witnesses, each of whom is examined by the plaintiff's counsel and cross-examined by the defendant's counsel. At the end of the plaintiff's case the defendant presents their case following the same pattern: opening address followed by evidence. Each party then makes their closing submissions. Decisions about the order in which witnesses are called, the amount of time spent on each part of the trial, and the structure and emphasis of the closing submissions are made by the parties and their legal representatives, rather than by the court.

\footnotetext{
$78 \quad$ Ibid.

79 Ibid [63]-[66].

80 Interview with Chief Justice Wayne Martin (Perth, 6 March 2013); Interview with Justice Robert McDougall (Sydney, 6 June 2012); Interview with Justice Peter McClellan (Melbourne, 5 June 2012); Interview with the Honourable Neville Owen (King's Park, WA, 5 March 2013); Interviews with Participants B and G.

81 Australian Securities and Investments Commission v Rich (2009) 236 FLR 1, 31 [60].

82 Interview with Participant D.

83 Interview with Justice Robert McDougall (Sydney, 6 June 2012); Interview with Justice Peter McClellan (Melbourne, 5 June 2012); Interview with Participant B. 
In keeping with contemporary case management principles, the structure of trials has become more flexible. The courts have assumed more control over the way in which trials are run..$^{85}$ It should come as no surprise that judges in mega-litigation have been particularly active, flexible and creative in this area. A number of interview participants reported taking a proactive role in creating a timetable setting out the way the trial was to run. ${ }^{86}$ Ray Finkelstein adopted the practice of sending to the parties, some weeks prior to trial, a timetable for trial that he had developed based on his assessment of the time each step in the trial was likely to take. The timetable would, for example, set a time for the plaintiff's opening and a time by which the plaintiff would finish calling their witnesses. If the parties took issue with any aspect of the timetable, this would be the first matter dealt with at trial. ${ }^{87}$ Other participants required the parties themselves to prepare similar timetables. ${ }^{88}$ During the Bell Group trial, Owen J developed a series of timetables, each named after a different Pope, ${ }^{89}$ which allocated a certain number of days or hours to various steps in the trial..$^{90}$ Another interview participant reported devoting two pre-trial directions hearings to deciding how the trial was to run: 'We have this amount of time, how are we going to fit into it? ${ }^{\prime 11}$

Participants who used trial timetables of this kind reported that parties usually stuck to the timetable, although there were occasional breaches and there was some flexibility in the timelines. ${ }^{92}$ The value of the timetable seemed to lie in setting targets for parties to work towards, rather than in the potential for strict enforcement. Ray Finkelstein observed that 'if [lawyers] are given times within which to complete various tasks, then lawyers do it. ${ }^{93}$ Peter McClellan made a

\footnotetext{
$85 \quad$ See Chapters 6 and 7.
}

86 Interview with the Honourable Ray Finkelstein QC (Melbourne, 21 November 2012); Interview with Justice Peter McClellan (Melbourne, 5 June 2012); Interview with the Honourable Neville Owen (King's Park, WA, 5 March 2013); Interviews with Participants A and B. Interview with the Honourable Ray Finkelstein QC (Melbourne, 21 November 2012). Interview with Justice Peter McClellan (Melbourne, 5 June 2012); Interview with Participant A. For instance, the final plan, which set out exactly how the trial was going to finish, was named 'Plan Benedict' after the newly elected Pope: Interview with the Honourable Neville Owen (King's Park, WA, 5 March 2013).

90 Interview with the Honourable Neville Owen (King's Park, WA, 5 March 2013).

91 Interview with Participant B.

92 Interview with the Honourable Ray Finkelstein QC (Melbourne, 21 November 2012); Interview with the Honourable Neville Owen (King's Park, WA, 5 March 2013); Interview with Justice Peter McClellan (Melbourne, 5 June 2012); Interview with Participant B. Interview with the Honourable Ray Finkelstein QC (Melbourne, 21 November 2012). 
similar observation: 'people tend to meet the target'.$^{94}$ If, on the other hand, no target is set, 'it just tends to be open-ended and keep going. ${ }^{95}$

Some judges were prepared to intervene further than setting a timetable for the trial. Peter McClellan explained a process of 'phasing' trials, employed in the Commercial List of the Supreme Court of New South Wales. ${ }^{96}$ In this process, the judge can direct the parties when to call their witnesses. Instead of hearing all the plaintiff's witnesses, followed by all the defendant's witnesses, the judge might direct that all witnesses on a particular issue give evidence consecutively. This can ensure that the judge receives the evidence in a logical order. For instance, in the Alstom Power trial, the judge directed that the evidence of two key witnesses to disputed events (one witness for either side) be given consecutively. ${ }^{97}$ The judge can use this technique to make sure that all of the relevant lay evidence is taken before an expert gives evidence, so that there is a solid factual basis for the expert evidence. ${ }^{98}$ This avoids the wasteful situation in which an expert's evidence is worthless because it is not consistent with the facts established at trial, or is given on the basis of a series of alternative factual situations, only one of which turns out to be established.

As with other techniques outlined in this chapter, structuring trials in this way does not necessarily involve pursuing efficiency at the expense of justice between the parties. Rather, it employs judicial involvement and ingenuity in order to make the best possible use of the trial time, avoiding waste and ensuring that the material is delivered in a way that is useful to the trial judge. All that is compromised is the ability of the parties to decide how the case will be run, and how much court time will be occupied.

As noted above, one of the benefits of phasing trials is the presentation of the material to the judge in a logical order. This brings us to the next major group of techniques for managing mega-litigation: controlling the presentation of evidence.

\section{PRESENTING EVIDENCE}

As well as exercising control over the order of events at trial, judges in megalitigation have been willing to influence the way in which evidence is presented. Mega-litigation, of course, involves massive volumes of oral and documentary evidence. Judges employ a range of techniques to control the way in which evidence

\footnotetext{
94 Interview with Justice Peter McClellan (Melbourne, 5 June 2012).

95 Ibid.

$96 \quad$ Ibid

97 See Alstom Power Ltd v Yokogawa Australia Pty Ltd (No 4) [2012] SASC 109, [4].

98 Interview with Justice Peter McClellan (Melbourne, 5 June 2012).
} 
is put before the court. As discussed in the previous section, judges can determine the order in which evidence is presented. In this section I outline some additional techniques used to deal with evidence in mega-litigation: handling documentary evidence; the use of written witness statements; resolving objections; limiting crossexamination; and, finally, a feature of almost any mega-litigation matter: expert evidence.

\section{A Documentary Evidence}

Mega-litigation typically involves vast quantities of documents. ${ }^{99}$ This chapter has already considered the techniques judges use to make the morass of documents more manageable during discovery. ${ }^{100}$ But even a tightly controlled discovery process might turn up thousands of relevant documents. It is common, in complex litigation, for parties to tender 'bundles' of documents rather than establishing the relevance and admissibility of each document separately. This process can save time by obviating the need to deal with each document separately. However, several interview participants found that these bundles usually included a large proportion of documents of, at best, marginal relevance. ${ }^{101}$ One participant had presided over a mega-litigation matter in which almost every document in a bundle of around 60 volumes proved to be relevant; but that participant said this situation was unusual, and that in other large cases only $10-20 \%$ of documents in a bundle were relevant. ${ }^{102}$ Another participant made a similar observation:

Most of the stuff you see in a big case is never read, never referred to, it's wheeled into court by gloomy looking paralegals and gloomy looking first or second year solicitors who are wondering why they ever took up law. ... And you sit there and you see these masses of paper being wheeled in and it's not looked at. It's all done on some sort of precautionary principle that it might be necessary. ${ }^{103}$

This excessively cautious approach to tender bundles increases costs for the parties: every document included in the bundle must be handled and photocopied multiple

\footnotetext{
$99 \quad$ See Chapter 3 at $30-1$

100 At 161-3.

101 Interview with the Honourable Michael Black AC QC (Melbourne, 22 November 2012);

Interview with the Honourable Ray Finkelstein QC (Melbourne, 21 November 2012); Interview with the Honourable Malcolm Lee QC (Fremantle, 6 March 2013); Interviews with Participants $\mathrm{B}, \mathrm{E}$ and $\mathrm{F}$.

102 Interview with Participant B.

103 Interview with the Honourable Michael Black AC QC (Melbourne, 22 November 2012). Ray Finkelstein also observed that in a typical complex case, $90 \%$ of the documents included in a tender bundle were not referred to at trial: Interview with the Honourable Ray Finkelstein QC (Melbourne, 21 November 2012).
} 
times. It also makes the judge's task more difficult: the judge has to absorb large amounts of material, often with little guidance about its relevance to the issues. One interview participant lamented:

People just hand you up a disk or a memory stick and say 'well, that's the evidence' ... and it's a whole mass of material. Now ... a judge has got to read it, synthesise it, deal with it if it's relevant (and most of it isn't) in a judgment. ${ }^{104}$

Participants had developed techniques for dealing with over-inclusive tender bundles. For one Federal Court judge, the solution lay in proactive case management. This participant would engage with the parties, from an early stage of the proceedings, to identify the real issues in the case. Decisions about the management of evidence would flow from this:

It's the issue identification which is absolutely critical. And the next question is 'how do I go about resolving that disputed issue of fact or law in the most efficient manner possible? Who are you calling to give evidence about that? What are they going to prove? Where's proof of this aspect?' And so when I said to [the parties in a mega-litigation matter] 'How are you going to prove the debts?' [they said] 'Oh, we've got 25 files'. 'Uh-uh. I don't want them. I do not want them. Imagine the cost of photocopying them. No.' ${ }^{\prime 105}$

By engaging in this sort of dialogue with the parties, this participant aimed to put in place, at an early stage, a strategy for putting only the most relevant evidence before the court. Once again, the aim of this strategy is to avoid waste by focusing on the real issues. Once again, it requires the judge to be active, creative and flexible.

Ray Finkelstein developed a practice to ensure that he was left with only the key documents:

I would not read any document, or treat it as part of the evidence unless I was taken to it [during trial]. So that [counsel] would always point out that particular document was relevant for a stated reason. And if it was not referred to I always made it clear I would not treat it as part of the evidence in the case. So that if a party tendered five volumes of documents I did not those five volumes as part of the evidence. I treated it as a provisional tender, and it was made good if I looked at the documents. And then at the end of the case I would ask the

\footnotetext{
104 Interview with Participant F. See also Justice Kenneth Hayne, 'The Vanishing Trial' (Paper delivered at Supreme and Federal Courts Judges Conference, Sydney, 23 January 2008), 19-20 (quoted in Chapter 4 of this thesis at 50-1) on the ease with which technology allows lawyers to tender massive amounts of material with little attention to its relevance. Interview with Participant E.
} 
solicitors to take out all the documents not referred to. Often $90 \%$ or more were removed. 106

In the Lehman Brothers litigation, Justice Steven Rares has been reported as taking an even harder line on tender bundles, refusing to accept any document unless its relevance was explained: ${ }^{107}$

Why should I be made to go away and sit in my chambers, maybe understand it or not understand it properly as it's intended to be understood? The only purpose of the documents is to persuade me that something happened or didn't happen; giving me 20 volumes of stuff to read is not going to help me. ${ }^{108}$

In the Bell Group litigation, Neville Owen employed a similar technique:

There were these tens and tens of thousands of documents. And I said to [counsel] 'you're not just going to open by saying "well, there are the documents and all will be revealed unto you in the fullness of time." In your opening you've got to take me to the documents that you say are critical to your case and tell me why.' ${ }^{109}$

Owen found this technique was not an unqualified success in terms of efficiency gains. Counsel went through a large number of financial records at a level of detail 'that, in retrospect, was unnecessary. All I needed was the end result.'110 Owen reflected that more intense judicial intervention could have overcome this problem: 'I didn't tread hard enough on this'. ${ }^{111}$ The result was that the plaintiff's opening ran for around 120 days. ${ }^{112}$

It is clear that, if documentary evidence in mega-litigation is to be kept within reasonably manageable bounds, the lawyers for each party must make a serious effort, before trial, to identify the relevance of each document to the issues. As with other techniques discussed in this chapter, this relies on early identification of the real issues in dispute. Another important point, for the purposes of this thesis, is that judges do not appear to take the view that more documents necessarily lead to a more accurate decision. On the contrary, an overwhelming number of documents can draw attention away from the most important documents and thus hinder the

\footnotetext{
106 Interview with the Honourable Ray Finkelstein QC (Melbourne, 21 November 2012).

107 Elizabeth Sexton, 'Judges Turn to Oral Evidence to Cut Paperwork', Sydney Morning Herald, 28 March 2011.

108 Quoted in ibid.

109 Interview with the Honourable Neville Owen (King's Park, WA, 5 March 2013).

110 Ibid

111 Ibid

112 Ibid.
} 
judge's ability to decide the case on its merits. Therefore, while restricting the scope of documentary evidence may mean that the parties cannot put in every document that they otherwise would have, it need not diminish the quality of justice between the parties.

\section{B Written Witness Statements}

While witnesses traditionally give their evidence verbally, judges may order that witnesses give evidence in written form. ${ }^{113}$ There are efficiency benefits to providing evidence in writing: the plaintiff's evidence can be put before the court instantaneously, without the judge, court staff and counsel for all parties having to sit through hours of examination-in-chief. But there are some well-known problems associated with witness statements. The preparation of witness statements, which may take many hours of lawyers' time, is a large cost for the parties to incur before trial. ${ }^{114}$ The finished product tends to be in the language of the lawyer, rather than the witness. ${ }^{115}$ Providing witness statements before trial gives the opposing party the opportunity to make swathes of technical objections to the evidence. ${ }^{116}$ And while witness statements may mean less time is spent in court, the judge still needs to read the statements. This exercise may be almost as time-consuming as - and sometimes less illuminating than - hearing the evidence viva voce. ${ }^{117}$

Interview participants' views on witness statements ranged from cautious acceptance to outright rejection. No participant embraced witness statements without reservation. Two participants who simply refused to use witness

113 See, eg, Uniform Civil Procedure Rules 2005 (NSW) r 31.1(3); Supreme Court Civil Supplementary Rules 2014 (SA) rr 169-172; Rules of the Supreme Court 1971 (WA) O 36 r 2. For an account of the move towards written evidence in Australian courts, see Justice Arthur R Emmett, 'Towards the Civil Law? The Loss of 'Orality' in Civil Litigation in Australia' (2003) 26 University of New South Wales Law Journal 447, 458-61. For a succinct explanation of how witness statements are compiled and used, see Justice Clifford Einstein, 'Reflections on the Commercial Litigation Landscape - Lessons From the Past - Moving Forward' (2005) 26 Australian Bar Review 145, 1479.

114 See Lord Woolf, Access to Justice: Interim Report (June 1995), Ch 22 [6]-[8]; Australian Law Reform Commission, Managing Justice, above n 21, [7.195]; Judiciary of England and Wales, above $n$ 3, 29 [69].

115 See, eg, Concrete Pty Ltd v Parramatta Design \& Developments Pty Ltd (2006) 229 CLR 577, 634 (Callinan J); Judiciary of England and Wales, above n 3, 29 [69]; Woolf, above n 114, ch 3; GT Pagone, 'Litigation and ADR' (Speech delivered at Construction Law Conference, Melbourne, 22 May 2008). See the section on dealing with objections, below at 179-81.

116 See, eg, Pagone, above n 115; Emmett, above n 113, 460.

117 See, eg, Concrete Pty Ltd v Parramatta Design \& Developments Pty Ltd (2006) 229 CLR 577, 634 (Callinan J). 
statements, for the reasons noted in the previous paragraph. ${ }^{118}$ Other participants had used witness statements in mega-litigation and, while acknowledging their drawbacks, had found them useful. ${ }^{119}$ Justice David Bleby considered that the use of witness statements for all of the evidence in chief in the Alstom Power litigation made the trial 'a lot shorter than it would have been'; some statements were hundreds of pages long and included hundreds of attachments. ${ }^{120}$

Witness statements are an example of a procedural innovation that has come full circle. Introduced as an efficiency measure, they have become (at least for some judges) the opposite. Even those who continue to use witness statements were aware of their downside.

\section{Objections to Evidence}

As noted above, if witness statements are exchanged before trial, there are likely to be some objections to the content of those statements. Equally, where large numbers of documents are involved there may be objections to the tender of some. Arguments about the admissibility of evidence can consume large amounts of court time. A number of interview participants had developed methods for dealing efficiently with large numbers of objections. While the detail of these methods varied, the central concept was similar: objections are divided into categories; the judge hears argument and makes a ruling on one objection in each category; that ruling is applicable to all objections in that category. ${ }^{121}$ This saved large amounts of time that would otherwise have been spent arguing about each objection. Other participants took the approach of encouraging parties to focus only on those objections that really mattered. ${ }^{122}$ David Bleby recalled that 'sheets and sheets' of objections in the Alstom Power trial 'fell away' over the course of the trial:

A lot of the objections were the sort of objections you'd take in a criminal trial before a jury - perhaps hearsay evidence. There was hearsay evidence, but I said 'I'm not going to act on hearsay evidence, I know what hearsay is, let's get on with it, let's not argue about it.' There were objections at that sort of level, and in

\footnotetext{
118 Interviews with Participants D and F.

119 Interview with Justice David Bleby (Adelaide, 16 February 2012); Interviews with Participants $B$ and $E$.

120 Interview with Justice David Bleby (Adelaide, 16 February 2012).

121 Interview with Justice Robert McDougall (Sydney, 6 June 2012); Interview with the Honourable Neville Owen (King's Park, WA, 5 March 2013); Interview with Participant B. See also Australian Securities and Investments Commission v Rich (2009) 236 FLR 1, [41] 25; Idoport Pty Ltd v National Bank Ltd [2000] NSWSC 1250. 
the end I think they either agreed that certain evidence would be admissible on certain conditions, or [couldn't] be bothered [objecting]..$^{123}$

Robert McDougall expressed similar frustration:

I can't stand wasting time on objections to evidence because they achieve absolutely nothing. I'm not a jury, I'm perfectly capable of seeing that evidence is inadmissible or irrelevant and ignoring it. So why do you spend half an hour arguing on it? ${ }^{124}$

Another participant, a Supreme Court judge, listed 'not entertaining facile objections to evidence' among the steps he took to improve efficiency without compromising justice in mega-litigation. ${ }^{125}$ Neville Owen took a 'pragmatic approach' to rulings on the admissibility of evidence in the Bell Group trial. ${ }^{126}$ On technical objections to expert evidence, for example, he took the following approach:

In the end these are questions of weight. That's what I do for a living. Trust me. And just as an example, ... the plaintiff was the liquidator of the Bell companies. ... One of the issues in the case was: were the companies insolvent on a particular day? [The defendants said] 'He can't give an opinion on that'. I said 'yes he can'. 'No, he's too close to the case.' 'That's a matter of weight. Technically you might be right.' They were putting to me reams and reams of authority on that issue, the other side were putting up reams and reams of authorities on the counterissue. [I said] 'It's a question of weight. I'll see him in the witness box, if I think he's not being objective and dispassionate in expressing that particular opinion ... then it's going to count in weight. But I'm going to let it in. ${ }^{127}$

This pragmatic approach to the rules of evidence was aimed at improving efficiency by cutting short legal argument on issues that had marginal bearing on the real issues. It illustrates the flexibility with which the mega-litigation judge approaches procedure: the rules of evidence need not be applied in a strict or technical manner.

Pragmatic approaches to the admission of evidence are a manifestation of the broader shift of control of litigation from the parties to the court. ${ }^{128}$ These methods of dealing with objections are an instance of prioritising public justice, public efficiency and party efficiency ahead of justice between the parties. They involve the judge refusing to hear argument on issues that the parties wish to agitate and that

\footnotetext{
Interview with Justice David Bleby (Adelaide, 16 February 2012).

Interview with Justice Robert McDougall (Sydney, 6 June 2012).

Interview with Participant A.

Owen, 'Surpassing Sisyphus', above n 50, 8-9; Owen interview, above n 49.

Interview with the Honourable Neville Owen (King's Park, WA, 5 March 2013).

This trend is discussed in Chapters 6 and 7. .
} 
may be relevant to the real issues in dispute, albeit peripheral. The intrusion on justice between the parties is minimal: parties are prevented from taking every possible procedural point, but participants seemed confident that this did not hinder the presentation of the substance of the case. Even so, these methods are significant for this thesis because they illustrate the point at which the objective of doing justice between the parties gives way to the other objectives of civil procedure.

\section{Limits on Cross-Examination}

The reception of oral evidence is one of the most time-consuming aspects of a typical mega-litigation trial. There may be many witnesses, ${ }^{129}$ and the evidence of some of those witnesses may be extremely wide-ranging. As discussed above, the time spent in court can be reduced by receiving evidence-in-chief in writing. ${ }^{130}$ Witness statements, however, do not obviate the need for cross-examination. In megalitigation, cross-examination of a single witness can continue for days, weeks or even months. ${ }^{131}$ Driven by a desire to improve efficiency, judges in mega-litigation may impose time limits on cross-examination. ${ }^{132}$

Part way through the trial in the Idoport litigation, Einstein J announced his intention to place strict limits on cross-examination for the remainder of the trial. While he appreciated that the limitation of cross-examination was 'a highly sensitive area', 133 the scale of the litigation justified the imposition of limits: his Honour had calculated that cross-examination of the 160 witnesses would consume 3.8 years of court time. ${ }^{134}$ Einstein J explained how the new regime would work:

$[P]$ rior to commencing cross-examination of any particular witness ... the Court will require a detailed statement of the topics ... proposed to be covered and a detailed estimate of the time anticipated ... for cross-examination on those topics.

129 For example, 156 witnesses gave oral evidence in the Bell Group trial: Westpac Banking Corporation v Bell Group Ltd (in liq) [2009] WASCA 223, [2]. There were 37 witnesses in ASIC v Rich (Australian Securities and Investments Commission v Rich (2009) 236 FLR 120 [23]), and 160 in Idoport (Idoport Pty Ltd v National Australia Bank Ltd [2001] NSWSC 868, [75]).

$130 \quad$ See above at $178-9$.

131 For example, one witness in the Alstom Power litigation was cross-examined for 17 days (Interview with Justice David Bleby (Adelaide, 16 February 2012)). In Pacific Acceptance Corporation Ltd $v$ Forsyth the principal witnesses for the plaintiff and defendant were in the witness box for four months and three months respectively: Pacific Acceptance Corporation Ltd $v$ Forsyth (1970) 92 WN (NSW) 29, 39, 44.

132 The UK Commercial Court's Long Trials Working Party recommended that this technique be used in long trials: Judiciary of England and Wales, above n 3, 51 [149]-[151]. See also Federal Judicial Center, above n 3, 127 [11.644], 147-8 [12.35]; Seven Network Ltd v News Ltd [2007] FCA 1062, [24]. Idoport Pty Ltd v National Australia Bank Ltd [2001] NSWSC 868, [75]. Ibid [76]. 
Having heard such statements and estimates, the Court will then identify a period of time which it sees as appropriate for that cross-examination. In the absence of a special case made on an appropriate occasion by formal application, no cross-examination in excess of the Court-imposed period of time will be permitted in respect of any witness. ${ }^{135}$

Einstein J further explained that this technique would require counsel to take pains to focus on the real issues:

A very strict discipline to be generally applied across the board is calculated to ensure that very great care indeed is taken to identification of particularly important areas for cross-examination and to avoid meticulous cross-examination [on] every piece of paper ever written or seen by a witness. ${ }^{136}$

Einstein J's judgment in this matter displays some tension between, on the one hand, the pressing need for efficiency in mega-litigation; and, on the other hand, the seriousness of limiting cross-examination. The rules of natural justice, he said, were 'the lodestar for the administration of justice in the case'; ${ }^{137}$ but natural justice did not equate to giving the parties an unlimited opportunity to present their case. ${ }^{138}$

Interview participants who commented on the issue were similarly ambivalent about placing limits on cross-examination. On the one hand, several acknowledged that it was sometimes necessary to impose time limits. Justice David Harper of the Supreme Court of Victoria had no doubt

that limitations on cross-examination, limitations even on examination in chief, are necessary in order to contain the area of dispute and in the end to do justice not only to the parties to the litigation in reducing the cost and the time that litigation takes, but also to the court system and the other litigants who are caught up in the court system. ${ }^{139}$

As discussed above, ${ }^{140}$ some participants established timetables for trial, which had the effect of limiting the time available for cross-examination. In the $C 7$ judgment, Sackville J noted that:

While (perhaps wrongly) I did not impose rigid time limits on cross-examination, I attempted to insist, to the maximum extent practicable, on adherence to the

Ibid [75].

Ibid [78].

Ibid [79].

See ibid [77].

Interview with Justice David Harper (Melbourne, 19 November 2012).

At 173-4. 
cross-examiner's estimate of the time required to complete the questioning of each witness. ${ }^{141}$

On the other hand, participants were generally cautious about limiting crossexamination. One Supreme Court judge ${ }^{142}$ said he had never felt the need to place a limit on cross-examination, and doubted whether he would ever do so; counsel 'would want to be pretty long winded' in order for him to even consider this option. Peter McClellan, who had found timetables for trial a useful technique, said that these timetables could be enforced 'if you are fair about it, but you will get into trouble if you're not fair. In other words if someone doesn't get a proper opportunity [to present their case].' ${ }^{143}$ McClellan did report that in some cases he would strongly encourage counsel to truncate their cross-examination:

I not infrequently intervene in someone's cross-examination and tell counsel bluntly 'what you're doing now is not helping me. Let's move on to something else...' But that's a matter of the management skill of the judge and the particular circumstances of the case. ${ }^{144}$

Ray Finkelstein said that he would generally enforce a trial timetable simply by looking at the clock and saying 'time is up'. ${ }^{145}$ There was, however, 'a degree of flexibility'; 'I kept parties pretty closely to the timetable, without being too irrational about it.' ${ }^{\prime 46}$ Finkelstein did not think that imposing time limits fundamentally changed the way in which counsel presented their clients' case; 'it just means that they had to be efficient. ... They stick to the issues much more closely than if they had been unsupervised.' ${ }^{\prime 47}$

In the Bell Group trial, Neville Owen found the mere threat of shutting down crossexamination was effective:

I always held the threat over them that unless they behaved themselves I would put a time limit on cross-examination, but it never got to that. ... I think they were always aware of that, they knew I was serious, that I would do it. ${ }^{148}$

Remarkably, not one of the 156 witnesses was cross-examined for more than four days, and Owen never had to make good his threat to close down cross-examination.

\footnotetext{
$141 \quad$ Seven Network Ltd v News Ltd [2007] FCA 1062, [24].

142 Interview with Participant D.

143 Interview with Justice Peter McClellan (Melbourne, 5 June 2012).

144 Ibid.

145 Interview with the Honourable Ray Finkelstein QC (Melbourne, 21 November 2012)6.

146 Ibid.

147 Ibid

148 Interview with the Honourable Neville Owen (King's Park, WA, 5 March 2013).
} 
In multi-party mega-litigation, eliminating duplication of cross-examination can save time. In $C 7$, Sackville J made a ruling that 'the main burden of cross-examining each of Seven's witnesses ordinarily would be carried by one of the Respondents'. ${ }^{149}$ Counsel for any of the other respondents 'could cross-examine only if there was an issue, peculiar to its case, requiring additional questions to be put to the witness.'150 The result was that cross-examination, 'although usually very thorough, did not involve significant duplication.' ${ }^{151}$

All of these methods of limiting cross-examination save time. Yet all are tempered by the need to do justice between the parties. In particular, participants were sensitive to the requirements of procedural fairness. Limits were not enforced rigidly; they were flexible enough to be altered to ensure that all issues were covered and that the parties received a fair hearing. The variety of views about the appropriateness of limiting cross-examination at all, and the vigour with which limits could be enforced, reflect another recurring theme of the last two chapters: the management of mega-litigation depends, to a significant extent, on the attitude and personality of the individual judge.

\section{E Expert Evidence}

Mega-litigation almost inevitably involves extensive expert evidence. ${ }^{152}$ This is one source of 'excessive expense, delay and ... complexity' in mega-litigation. ${ }^{153}$ In the last 20 years there have been significant developments in the management of expert evidence and there is now extensive literature on this topic. ${ }^{154}$ The aim of this section is not to repeat or summarise that literature - the role of experts in mega-litigation could itself be the topic of a thesis - but rather to identify some trends in the way that courts handle expert evidence in mega-litigation. These trends share similarities

\footnotetext{
$149 \quad$ Seven Network Ltd v News Ltd [2007] FCA 1062, [10].

$150 \quad$ Ibid. One interview participant (Participant B) reported using similar techniques.

$151 \quad$ Seven Network Ltd $v$ News Ltd [2007] FCA 1062, [10].

152 See discussion in Chapter 3 at 48-9.

153 Legg, above n 3, 95. See also Seven Network Ltd v News Ltd [2007] FCA 1062, [22]. ASIC v Rich is an example of a mega-litigation matter in which the disputes over expert evidence were extensive, hard fought and ultimately significant for the outcome of the trial. See ASIC $v$ Rich (2005) 190 FLR 242; ASIC v Rich [2005] NSWSC 650; ASIC v Rich [2005] NSWSC 939; ASIC v Rich [2005] NSWSC 999. For a summary of these disputes, see ASIC $v$ Rich (2009) 236 FLR 1, 24.

154 See, eg, Ian Freckelton and Hugh Selby, Expert Evidence (Thomsons looseleaf); New South Wales Law Reform Commission, Expert Witnesses, Report 109 (June 2005); Federal Court of Australia, Case Management Handbook (13 October 2011), Ch 12; Gary Edmond, 'Secrets of the Hot Tub: Expert Witnesses, Concurrent Evidence and Judge-Led Reform in Australia' (2008) 27 Civil Justice Quarterly 51; Stephan Millett, 'Ethics of Expert Evidence' (2013) 87 Australian Law Journal 628; JA Devereux, 'Providing Expert Evidence in an Australian Court: A Lawyer's View' in Roy G Beran, Legal and Forensic Medicine (Springer, 2013) 1007.
} 
with many of the other procedural techniques discussed in this chapter: intensive, creative judicial case management is used to ensure evidence is presented in a way that is useful to the court, but not always in accordance with the parties' wishes.

The 'traditional approach to experts' 155 involves each party selecting their own expert, who prepares a written report which is tendered as the expert's evidence-inchief. The expert is then cross-examined by counsel for the opposing party. This traditional method is rarely used in mega-litigation without significant modification. Techniques have been developed to narrow the divisions between experts for opposing parties and to make expert evidence more accessible for the judge. Wayne Martin explained that

There's a real danger, from my experience, ... that the expert ... witnesses are like ships passing in the night because they're not engaging on the same questions, they're not making the same factual assumptions, they're not even in the same field of expertise. ${ }^{156}$

To avoid these dangers, experts in complex litigation are often required to engage in a conference before trial. In an expert conference, the experts for all parties meet prior to trial and prepare a joint report recording the issues on which they agree and disagree. ${ }^{157}$ The process 'is intended to save time and money by identifying before the trial the real issues of disagreement, and the common ground relating to the relevant matters.' ${ }^{158}$ Several interview participants spoke about the usefulness of the expert conference: ${ }^{159}$ 'Cuts down money. We end up with joinder of issues and not ships passing in the night, and it's better for us.' ${ }^{160}$ The judge may have an active role to play in setting the procedure and agenda for the expert conference, including setting the precise questions that the experts are to address. ${ }^{161}$

\footnotetext{
155 Legg, above n 3, 97-8.

156 Interview with Chief Justice Wayne Martin (Perth, 6 March 2013).

157 See, eg, Federal Court of Australia, Case Management Handbook, above n 21, 71 [12.29]; Federal Court Rules 2011 (Cth) r 23.15; Court Procedures Rules 2006 (ACT) r 1211; Uniform Civil Procedure Rules 2005 (NSW) r 31.24-26; Supreme Court Rules (NT) r 44.05; Uniform Civil Procedure Rules 1999 (Qld) r 429B; Supreme Court Civil Rules 2006 (SA) r 213(2); Supreme Court Rules 2000 (Tas) r 516(6); Supreme Court (General Civil Procedure) Rules 2005 (Vic) r 44.06.

$158 \quad$ New South Wales Law Reform Commission, above n 154, 92 [6.34].

159 Interview with Justice Peter McClellan (Melbourne, 5 June 2012); Interview with Justice Robert McDougall (Sydney, 6 June 2012); Interviews with Participants D and E. Interview with Participant E. See New South Wales Law Reform Commission, above n 154, 94-5 [6.43].
} 
In fact, the judge's role in the preparation of the expert evidence may begin at a very early stage in proceedings. ${ }^{162}$ The Federal Court's Class Action and Electronic Trial Guide recommends that the court should direct parties to exchange the following information before experts are even retained:

(1) expertise of the proposed experts - a copy of the resume to be provided;

(2) proposed questions for the expert; and

(3) list of materials proposed to be provided to the expert. ${ }^{163}$

The exchange of this material forestalls argument about the admissibility of expert reports, 'thereby reducing expense and time.'164 Wayne Martin reported using a similar technique, in a mega-litigation matter, of taking control of the expert evidence at an early stage by convening a case management conference:

What I said was ... 'we're going to have a conference, we're going to identify the fields of expertise in which we think expertise is required, then the questions that need to be answered within those fields of expertise, and then the factual assumptions that can be made by the experts on the basis they're not contentious, and then the various permutations of the factual possibilities that are contentious.' So that then you've got the [expert] opinion covering as many of the possible factual outcomes as might emerge from the case, because of course the expert opinion is only as good as the facts on which it's based; if the expert assumes facts that don't match those found by the judge the opinion is useless. So that way you hopefully produce the result of the experts confronting each other head on... ${ }^{165}$

Judicial intervention in the management of expert evidence is not confined to the pre-trial processes. Concurrent evidence, colloquially known as 'hot-tubbing', is now a well-established technique for presenting complex expert evidence to a court. ${ }^{166}$ In this procedure, two or more experts whose evidence relates to the same issue are sworn in and give evidence at the same time, with questioning generally

\footnotetext{
162 See Judiciary of England and Wales, above n 3, 31 [78].

163 Class Action and Electronic Trial Guide, Federal Court of Australia (2012) (Copy on file with author), 22 [10.1].

164 Ibid.

165 Interview with Chief Justice Wayne Martin (Perth, 6 March 2013).

166 See Justice Steven Rares, 'Using the "Hot Tub" - How Concurrent Expert Evidence Aids Understanding Issues' (paper presented at the New South Wales Bar Association Continuing Professional Development seminar: Views of the "Hot Tub" from the Bar and the Bench, Bar Association Common Room, 23 August 2010); Justice Peter McClellan, 'New Method With Experts - Concurrent Evidence' (2011) 3 Journal of Court Innovation 259; New South Wales Law Reform Commission, above n 154, 95-100; Federal Court of Australia, Case Management Handbook, above n 3, 74-6 [12.44]-[12.59].
} 
led by the judge rather than by counsel. Peter McClellan has described concurrent evidence as

essentially a discussion chaired by the judge in which the various experts, the parties, the advocates and the judge engage in a cooperative endeavour to identify the issues and arrive where possible at a common resolution of them. ${ }^{167}$

McClellan describes the general process of taking concurrent evidence:

The experts are sworn together and, using the summary of matters upon which they disagree [drawn from the conference of experts], the judge settles an agenda with counsel for a 'directed' discussion, chaired by the judge, of the issues in disagreement. The process provides an opportunity for each expert to place his or her view on a particular issue or sub-issue before the court. The experts are encouraged to ask and answer questions of each other. The advocates also may ask questions during the course of the discussion to ensure that an expert's opinion is fully articulated and tested against a contrary opinion. At the end of the discussion, the judge will ask a general question to ensure that all of the experts have had the opportunity to fully explain their positions. ${ }^{168}$

It is obvious from this description that, like many of the other techniques discussed in this chapter, concurrent evidence requires intense preparation and involvement on the part of the judge.

Several interview participants reported using a concurrent evidence procedure for expert witnesses, ${ }^{169}$ while another had proposed using concurrent evidence in a mega-litigation matter but, facing opposition from all parties, had decided not to do so. ${ }^{170}$ Those participants who had used concurrent evidence were very positive about the process, observing that this method of giving evidence was more useful than sequential evidence:

In virtually every case ... concurrent evidence has been far more useful at disclosing the issues than sequential evidence. It takes more work from the judge because you have to get on top of the issues before - you can't let the evidence unfold as you would ordinarily do. So there's more upfront work. But it is incredibly useful to be able to hear one expert's opinion and then literally go [to

\footnotetext{
167 McClellan, 'New Method With Experts', above n 166, 264.

168 Ibid.

169 Interview with Chief Justice Wayne Martin (Perth, 6 March 2013); Interview with Justice Peter McClellan (Melbourne, 5 June 2012); Interview with Justice Robert McDougall (Sydney, 6 June 2012); Interviews with Participants A, B, E and F. 
the other expert] and say 'what do you say about that?' ... Just brings the issues into focus far more efficiently I think. ${ }^{171}$

I had mining engineering experts - half a dozen perched in the jury box in a trial court, and they all went along swimmingly, pointing to things and drawing on the whiteboard and so on. And it was great. I understood the evidence, they narrowed their disputes, they cross-examined each other courteously and efficiently, and I had a very clear understanding of where that part was going. ${ }^{172}$

Another advantage of concurrent evidence was a shift in control of the process: ${ }^{173}$

It takes the expert witness away from the control of the lawyers, and the lawyers hate it because they lose control. And they complain about it, to which of course the response is 'well, that's why we're doing it'. Because we want the expert, not you [the lawyer] controlling the expert. ${ }^{174}$

Two participants, however, reported that concurrent evidence was not always successful. One Federal Court judge said 'Sometimes it's brilliant, sometimes it's not so brilliant. It's hard to work it out until you're in the middle of it, that's the sad thing.' ${ }^{175}$ Robert McDougall made a similar observation: 'There have been cases where it's worked brilliantly. And there have been cases where it has been a disaster.' 176 McDougall recalled one case in which the experts 'just hated each other and they were appalling, so I terminated that concurrent session.'

Ray Finkelstein recalled using a process similar to that of taking concurrent evidence, but with even less of a role for lawyers. In a complex, multi-party case involving more than 30 experts on several different topics, Finkelstein divided the experts into several groups, according to the issue on which they were giving evidence. He then sat around a table with each group and took the evidence of the experts:

I had the lawyers sitting on the other side of the room, and I said I would lead the evidence in chief and the lawyers were not allowed to interrupt. ... Previously I had gone through all the reports and started off by dealing with the topics I wanted specifically addressed, being those which I either did not understand or not all the experts dealt with. I had worked out a list of questions for each expert.

\footnotetext{
171 Interview with Participant B.

172 Interview with Justice Robert McDougall (Sydney, 6 June 2012).

173 Interview with Justice Peter McClellan (Melbourne, 5 June 2012); Interview with Participant F.

Ray Finkelstein reported a similar benefit from his modified version of concurrent evidence, discussed below at $188-9$.

174 Interview with Justice Peter McClellan (Melbourne, 5 June 2012).

175 Interview with Participant E.

176 Interview with Justice Robert McDougall (Sydney, 6 June 2012).
} 
... And then I had ascertained where the experts differed on issues ... I then ... asked them to explain those areas ... why there were different opinions. I did all of that and at the end of that process I allowed counsel [to] examine [the experts] for only one hour. Some took the opportunity, some did not. That was because at the end of that process most of the evidence was out, all the explanations were made. ${ }^{177}$

The keys to the success of this process were that it was 'as informal a process as could be done' and that it meant 'excluding the role of counsel'. Finkelstein found the process extremely efficient: 'I dealt with 30 experts in about five days. In ordinary court time it would have taken five weeks.'

Expert evidence has been a lively area of development in complex litigation over the last decade. But one Supreme Court judge thought that, while innovations such as expert conferences and concurrent evidence were helpful developments, they did not go far enough: 'Because there are too many experts. ... We can end up with seven or eight or nine experts on one topic.' ${ }^{178}$

The problem of 'too many experts' might be solved by using a court-appointed expert. This technique is rarely used in Australia, ${ }^{179}$ for several reasons. ${ }^{180}$ Because parties would undoubtedly retain their own experts at least to advise, if not give evidence, during the litigation, there would be minimal cost savings for the parties. ${ }^{181}$ The selection of an expert is not a task for which a court is necessarily well-equipped, and the court's choice of expert may be controversial - especially if the court repeatedly uses the same expert. ${ }^{182}$ An alternative to the court-appointed expert is to have the parties agree on (or agree on a process to appoint) a single joint expert. ${ }^{183}$ This in itself is not always ideal; where there is a genuine difference of views within the expert community on the relevant issue - which may often be the case in mega-litigation, given its complex and novel fact situations - hearing from only one expert may 'obscur[e] the lack of consensus.' 184 It may be that the most effective way of reducing the number of experts is the solution suggested by Sackville J in C7:

\footnotetext{
177 Interview with the Honourable Ray Finkelstein QC (Melbourne, 21 November 2012).

178 Interview with Participant D.

179 Federal Court of Australia, Case Management Handbook, above n 21, 70 [12.15]; Legg, above n 3, 106.

180 Federal Court of Australia, Case Management Handbook, above n 21, 70 [12.20].

181 Ibid; Judiciary of England and Wales, above n 3, 31-2 [81].

182 Federal Court of Australia, Case Management Handbook, above n 21, 70 [12.20].

183 See New South Wales Law Reform Commission, above n 154, ch 7; Legg, above n 3, 100-6.

$184 \quad$ Legg, above n 3, 104.
} 
In an age where mega-litigation is characterised by heavy, often unthinking reliance on expert evidence, the court may deem it appropriate to limit the number of reports or to restrict the volume of expert evidence. ${ }^{185}$

This suggestion was echoed by two interview participants. ${ }^{186}$ Importantly for the purposes of this thesis, the suggestion involves placing the objectives of efficiency and public justice ahead of the objective of justice between the parties. The proposal seems to rest on the view that additional experts will add very little to the resolution of the real issues - hence Sackville J's reference to the 'unthinking reliance' on experts. ${ }^{187}$ Nonetheless, limiting the number of experts does mean that the court misses out on hearing some expert views relevant to the issues in dispute, and thus results in some reduction (admittedly small) in the quality of justice dispensed to the parties.

One interview participant spoke of another, quite different, technique for dealing with expert evidence in mega-litigation. Rule 31.54 of the Uniform Civil Procedure Rules 2005 (NSW) provides:

In any proceedings, the court may obtain the assistance of any person specially qualified to advise on any matter in the proceedings and may act on the adviser's opinion.

Robert McDougall was, at the time of interview, proposing to make use of $\mathrm{r} 31.54$ to appoint an expert in construction programming to assist in a forthcoming megalitigation. He explained the role of this person in the litigation:

It's just someone who listens to the evidence and says [to the judge, out of court] 'look, that's all rubbish and this is correct and this is the problem' and you then go into court. And you use what you've been told to sound out with the parties and the expert witnesses, where things go. [Construction] programming is just such a difficult art ... [the independent expert] is a way of ensuring that I have an understanding of what I'm doing on the technical side of the case. ${ }^{188}$

The management of expert evidence has been a particularly fertile area of innovation in Australian litigation generally, and mega-litigation in particular. Voluminous and complex expert evidence, it seems, is an inevitable part of mega-litigation. The techniques outlined in this section are ways of reducing the cost and time consumed by expert evidence, while making the evidence easier for the judge to absorb. Once

\footnotetext{
185 Seven Network Ltd v News Ltd [2007] FCA 1062, [23].

186 Interview with Justice David Bleby (Adelaide, 16 February 2012); Interview with Participant D.

187 Seven Network Ltd v News Ltd [2007] FCA 1062, [23] (emphasis added).

188

Interview with Justice Robert McDougall (Sydney, 6 June 2012).
} 
again, the response to these challenges of mega-litigation has been to find better ways of handling the evidence. And once again, these responses have been characterised by a high degree of active involvement on the part of the judge. Judicial passivity, in this context, does not appear to be an option.

\section{CONTROLLING SUBMISSIONS}

The involvement of the mega-litigation judge in the management of a case is not limited to the pre-trial processes and the presentation of evidence. The judge can also influence the way in which legal argument, particularly in opening and closing submissions, is presented. Because it involves a multitude of contested issues, mountains of evidence, and lawyers with a 'battlefield mentality'189 prepared to leave no stone unturned, mega-litigation lends itself to extremely lengthy opening and closing submissions. ${ }^{190}$ This leaves the judge with the large task of reading and synthesising the material. One interview participant said a challenge of megalitigation was to 'avoid the parties snowing you with a huge amount of material,',191 while another said the mega-litigation judge may have to read '1000 pages of written submissions, many of which are not the least bit helpful.' ${ }^{192}$ Judges have responded to these challenges by assuming some control over the presentation of submissions.

One technique is to impose page limits on written submissions, ${ }^{193}$ or time limits on oral submissions. ${ }^{194}$ Some interview participants reported that they had placed such limits on submissions in mega-litigation. ${ }^{195}$ However, in general, participants thought that caution was needed when imposing limits. ${ }^{196}$ The concerns in this area

\footnotetext{
189 Ibid.

190 There were close to 5,000 pages of closing submissions in C7: Seven Network Ltd v News Ltd [2007] FCA 1062, [11]; almost 37,000 pages of closing submissions in Bell Group: Bell Group Ltd (in liq) v Westpac Banking Corporation (No 9) [2008] WASC 239, [960]; and over 4,000 pages of closing submissions in ASIC $v$ Rich: Australian Securities and Investments Commission $v$ Rich (2009) 236 FLR 1, [23] 21. Interview participant B reported hearing a case with over 1000 pages of written submissions.

191 Interview with Participant A.

192 Interview with Participant $\mathrm{H}$.

193 See, eg, Sackville, above n 1, 96-7; Westpac Banking Corporation v Bell Group Ltd (No 2) [2009] WASCA 223, [47]; Judiciary of England and Wales, above n 3, 49 [142].

194 See, eg, Australian Securities and Investments Commission v Rich (2009) 236 FLR 1, 28 [51]; Evan Bell, 'Judicial Case Management' (2009) Judicial Studies Institute Journal 76, 91; Judiciary of England and Wales, Report and Recommendations of the Commercial Court Long Trials Working Party (December 2007), 50 [145].

195 Interviews with Participants D and G.

196 This caution finds some support in the case law: see In the Marriage of Collins (1990) 14 Fam LR $162,174-5$.
} 
were similar to those relating to limiting cross-examination: ${ }^{197}$ procedural fairness must be maintained, and the limits must not jeopardise the judge's ability to decide the case on its merits. Peter McClellan said that it was 'a case by case exercise, and you've got to be very careful that you don't thereby deprive someone of proper process. ${ }^{\prime 198}$ In ASIC $v$ Rich, Austin J made a similar point:

The ever-present risk in that approach [placing limits on evidence or submissions] is that too strict a timetable will interfere with the fundamental right of a party to present his or her case to the court. ${ }^{199}$

One interview participant said that, while there were 'great virtues' in limiting submissions,

you've got to be careful not to, as it were, bite off your nose to spite your face. That you don't impose such arbitrary page limits that you are denying yourself as a judge the assistance that well-constructed written submissions ... can provide. ${ }^{200}$

Another participant took the approach of encouraging, rather than directing, shorter submissions:

The judge has to hammer home that long submissions will not help. I will try to discuss this with the parties. I will usually say, for example, that submissions should be about 20 pages. [I will tell them that] I don't want a novel - just an outline to direct me to the critical issues of law and fact and where I can find the relevant evidence. ${ }^{201}$

While limiting submissions may be something of a blunt instrument, several interview participants reported using more nuanced techniques to make submissions more efficient. In the Bell Group trial, Neville Owen used a 'judgment structure' to define the issues throughout the trial and, eventually, to form the basis for closing submissions:

From a very early stage I'd given the parties a document that had the headings that I was going to use for the judgment. And that was a work in progress. Each time a new draft would come out from me they had the opportunity to comment, and they did. But that also, I think, helped them to crystallise their thinking on issues. And that had another advantage: I said to them, 'when you do your closing submissions I want you to do your closing submissions, as far as you can,

\footnotetext{
197 See discussion above, 183-4.

198 Interview with Justice Peter McClellan (Melbourne, 5 June 2012).

199 Australian Securities and Investments Commission v Rich (2009) 236 FLR 1, 34 [63].

200 Interview with Participant G.

201 Interview with Participant $\mathrm{H}$.
} 
under those headings'. And that helped a lot, because it was so much easier then to follow the written closing submissions. ${ }^{202}$

Another participant reported using a similar technique. A list of the major issues in the proceedings was agreed before the trial. The parties then structured their closing submissions around the 'template' of those issues, and the judgment followed the same structure. This participant was pleased with the success of this technique: it 'got the litigation in a really good crisp clear shape, so we could all deal with it quite quickly'.203

Robert McDougall routinely uses a list of issues to run a long case, and as a basis for closing submissions. ${ }^{204}$ He requires the parties to produce an agreed list of issues at an early stage in the case, and then runs the case according to the list of issues. In a mega-litigation case, he found it an 'enormous help' to have an assistant keep a database of the evidence, catalogued under each issue. Finally, he gives a written direction 'that written submissions should address individually the issues in the agreed statement of issues:'

I force the parties to structure their submissions on the issues, so with any luck I've got from each party a note of all the evidence that it relies on in support of its case on each issue. And that helps you keep track of it.

For McDougall, the list of issues becomes 'the road map to the decision.' ${ }^{205}$

The Federal Court's Class Actions and Electronic Trials Guide also recommends the use of an 'agreed submissions template' for complex trials:

Raise agreed submissions template at early directions hearing. Parties should agree on a form of submissions template for opening submissions. During the trial, raise with the parties whether they want to use the same template for closing submissions, or whether it should be amended in light of what has transpired at trial.

Given [a] multiplicity of proceedings, parties and issues, the submissions template [can be] lengthy. In a case of such complexity, [practitioners have suggested] that the Court consider:

(1) a short list of 'issues for determination' (literally a couple of words each);

(2) early in the trial (any time up to about week 3 or 4) the Court's own list of topics it wished to see addressed in written submissions with two caveats:

\footnotetext{
202 Interview with the Honourable Neville Owen (King's Park, WA, 5 March 2013).

203 Interview with Participant F.

204 Interview with Justice Robert McDougall (Sydney, 6 June 2012).

205 Ibid.
} 
(a) each issue ought to be addressed;

(b) parties would not be restricted if they wished to address other additional topics. ${ }^{206}$

It is apparent that a submissions template, list of issues or judgment structure can help judges to keep track of the evidence and arguments in mega-litigation. These techniques relate to some of the other points discussed in this chapter: it is an example of intensive judicial case management in order to narrow and define the issues; and a template of issues can be used to structure the trial and determine how evidence is to be received. To be effective, this technique must be adopted from an early stage in proceedings, so the whole case can proceed on the basis of the template; it is not something that can be raised for the first time as counsel start to prepare their closing submissions. It calls for persistent judicial involvement and cooperation from the parties. Used sensitively, these techniques can reduce the volume of submissions without unfairly truncating argument on relevant matters. This is yet another example of active, creative case management being used to improve efficiency without compromising justice.

\section{USING TECHNOLOGY}

No discussion of techniques for managing mega-litigation would be complete without acknowledging the role played by modern technology. Mega-litigation has been at the forefront of the innovative use of technology in the court system. One of the first major electronic trials in Australia was the Estate Mortgage trial in the Supreme Court of Victoria, which ran for 80 sitting days in 1997.207 A special courtroom, containing over 50 computer monitors, was set up for the trial. ${ }^{208}$ The first electronic trial in South Australia was Southern Equities, beginning in 2001.209 Today, it is almost a given that mega-litigation trials will be conducted with the assistance of technology. ${ }^{210}$

\footnotetext{
206 Class Action and Electronic Trial Guide, Federal Court of Australia (2012) (Copy on file with author), 5 (emphasis in original).

207 Parliament of Victoria Law Reform Committee, Technology and the Law (May 1999), 174 [10.11].

208 Ibid.

209 The trial was expected to run for two years but settled in May 2002: Justice David Bleby, 'The First Electronic Trial, South Australian Supreme Court', paper prepared at the request of the Historical Collections Librarian of the Supreme Court library for the purpose of recording some of the judge's reactions as trial Judge to the electronic aspects of the trial, October 2002, 1. Examples include the trials in the Ingot Capital, Bell Group, Idoport, C7 and Centro litigation.
} 
While the term can be applied to various, slightly different, arrangements, ${ }^{211}$ an 'electronic trial' typically involves all of the important documents in the case (such as filed documents, exhibits and submissions) being stored in a database which is accessible to all parties, and the judge, both inside and outside the courtroom. Computer screens within the courtroom can display a document to all parties at the same time. Such a system offers practical benefits in savings of time and space. One lawyer involved in the Estate Mortgage case suggested that, had the 1.5 million documents in the electronic court book been required in hard copy, approximately 400 metres of 4-level shelving would have been required; he suggested the MCG would have been an appropriate venue for the trial. ${ }^{212}$ Justice David Bleby, who presided over an electronic trial in Southern Equities, ${ }^{213}$ found the process so successful that he ordered that there be an electronic trial in the Harris Scarfe litigation, another piece of mega-litigation. ${ }^{214}$ When he took control of the Alstom Power proceedings, which resulted in a 140-day trial, the matter had already been on foot for some years and it was too late to order an electronic trial. However, he was still able to make use of technology to save time during trial:

When I could see the volume of paper that was going to be prepared [in Alstom Power] I said 'this is ridiculous'... The movement of paper around the courtroom, in my experience in the earlier cases, takes up a huge amount of time, because everyone's got to reach the same page in the same lever-arch folder before you can proceed, and that's the witness, counsel and judge. And just the movement of that stuff around the court takes a huge amount of time. And I could see that was going to happen here because it hadn't been ordered to be an electronic trial. It should have been. ... I insisted eventually that the attachments to all the witness statements should be tendered electronically rather than in paper form. That saved a huge amount of paper. We got paper copies of the statements themselves I think. But they eventually were provided in electronic form as well, which has made the judgment writing a lot easier - I haven't even gone to the paper copies. So as the case went on we improved the technology, or made better use of technology, although it could have been run a lot better if it had been done properly from the beginning. ${ }^{215}$

\footnotetext{
211 For some descriptions of the features of electronic trials, see Allison Stanfield, Computer Forensics, Electronic Discovery and Electronic Evidence (LexisNexis, 2009), ch 6.

212 'Estate Mortgage Post Mortem', provided by the Honourable Tim Smith (copy on file with author), 8-9.

213 For an account of the use of technology in Southern Equities, see Bleby, 'The First Electronic Trial', above n 209. 
This experience highlights the advantages of having the trial judge manage the case from an early stage: a judge who knew they were going to hear the trial may have been more alert to the possibilities of using technology from an early stage. Other mega-litigation judges have echoed Bleby's observation that technology can reduce the time spent shuffling documents in court. ${ }^{216}$ In the C7 judgment, Sackville J reported that

Much hearing time was saved by avoiding the need for counsel and the Court to locate and retrieve hard copy documents either to put to witnesses or to refer to in submissions. It would have been virtually impossible to conduct the trial without the use of modern technology. ${ }^{217}$

It was estimated that the use of technology in this way reduced the hearing time by $25 \%$ in Southern Equities ${ }^{218}$ and by 50\% in Estate Mortgage. ${ }^{219}$ Even allowing for the impressionistic nature of these estimates, it is clear that technology can substantially reduce time spent in court (and, therefore, legal costs and consumption of court resources) without any reduction in the rigour or fairness of the hearing.

Other interview participants explained that having the documents available electronically was also useful when writing the judgment:

I love running electronic trials. It's just blissful to be able to go home with my computer and not have to take home boxes of books. Being able to word search, you know, 'didn't X say something in a document somewhere' and not having to sit there and flick through trying to find it. ${ }^{220}$

Neville Owen, who used an electronic court in Bell Group, has pointed out that access to electronic versions can help the judge make sense of a huge number of interrelated documents:

The real benefit of the electronic court book is its capacity to facilitate the tracking, linking and searching of the court record in all its forms. The ability to take an individual document and to identify within a matter of seconds every

\footnotetext{
216 Interview with Justice David Harper (Melbourne, 19 November 2012).

217 Seven Network Ltd v News Ltd [2007] FCA 1062, [10].

218 Bleby, 'The First Electronic Trial', above n 209, 5.

219 Parliament of Victoria Law Reform Committee, above n 207, 176 [10.15].

220 Interview with Participant E. David Bleby also commented on the assistance of technology at the judgment writing stage: Interview with Justice David Bleby (Adelaide, 16 February 2012). However, another participant, David Harper, who had used an electronic court room in a mega-litigation trial that settled, doubted whether the technology would have assisted with writing the judgment.
} 
reference to it in a pleading, a witness statement, a submission or a transcript ought not to be underestimated. ${ }^{221}$

There are other ways, apart from the electronic trial, in which technology has been employed in mega-litigation. Video links can be used to take the evidence of remote witnesses. This can achieve savings for the parties; the cost of having an expert or senior executive give evidence by video link for several hours is likely to be much less than the cost of bringing that witness to the city where the trial is being held, which may take up several days of the witness' time. ${ }^{222}$ Electronic filing enables all parties to have access to documents as soon as they are filed. ${ }^{223}$ Real-time transcript allows teams of lawyers to follow the progress of a trial from remote locations. ${ }^{224}$ The potential for technology to enhance the mega-litigation process is limited only by the ingenuity of the participants. Ray Finkelstein, for instance, set up a closed circuit television system to stream the taking of evidence from expert witnesses in a round-table setting to a public area. ${ }^{225}$ He explained that he did not want the process interrupted by people entering and leaving the room while the witnesses were being questioned, but was conscious of the open court principle and the parties' express wishes to observe the process. ${ }^{226}$ In an interlocutory judgment in the Bell Group proceedings, ${ }^{227}$ Neville Owen explained that limited resources are forcing courts to find new ways of using technology:

Every year it becomes more difficult for courts to extract from governments a level of resources that bears a reasonable relationship to the cost of providing a system of justice that the courts believe is in the public interest. This necessitates, among other things, resort to technology to provide new and different

$221 \quad$ Owen, 'Surpassing Sisyphus', above n 50, 17.

222 The benefits of video link evidence may not be as great as they first appear. For one thing, differences in time zones may mean there is a limited window of time each day in which the evidence of a witness in the Northern Hemisphere may be taken: see Australian Securities and Investments Commission v Rich (2004) 49 ACSR 578, 581-9. For a discussion of the challenges and advantages of video link evidence, see Justice Robert D Nicholson, 'The Paperless Court? Technology and Courts in the Region' (2002) 12 Journal of Judicial Administration 63, 72-4.

223 Participant D reported that this was a benefit of electronic filing.

224 Although note the comments in Class Action and Electronic Trial Guide, Federal Court of Australia (2012) (Copy on file with author), 12, that the 'cost of real time transcript far outweighed its use'.

225 Interview with the Honourable Ray Finkelstein QC (Melbourne, 21 November 2012). See the description of this process above at 188-9.

226 Interview with the Honourable Ray Finkelstein QC (Melbourne, 21 November 2012).

227 Owen J decided that the evidence was to be taken partly by videolink, and partly by relocating the Court to London. 
mechanisms for trying cases where to do so will enable scarce resources to be spread but without imperilling the integrity of the system generally. ${ }^{228}$

The majority of interview participants said technology was important or even essential in mega-litigation, and were open to adopting new ways of using technology. ${ }^{229}$ However, some acknowledged a degree of resistance, within the legal profession and amongst judges, to the use of technology. ${ }^{230}$ This resistance may break down as new generations of technologically literate lawyers progress through the system. Introducing new technology can be expensive, and courts may struggle to secure funding to implement up-to-date technology. Finally, it is inevitable that technology will not always work perfectly, and technological problems during trial may cause inconvenience and delay. ${ }^{231}$ Improvements in technology should minimise the occurrence of these problems. In any event, they can be seen as a cost to be weighed against the benefits of using technology in the courtroom.

\section{MANAGING RELATIONSHIPS}

The techniques discussed in this chapter so far have been practical ways of making the presentation of evidence and argument in mega-litigation more manageable. But one major challenge of mega-litigation has nothing to do with the legal of factual issues. That is the interaction, at a personal level, between the people involved in the case.

As discussed in Chapter 4, ${ }^{232}$ mega-litigation tends to heighten lawyers' adversarial instincts. Opposing counsel in a mega-litigation trial spend the better part of each working week for months or years in the same court room, and many more hours out of court in correspondence or negotiation with one another. Engagement on opposing sides of an adversarial exercise over such a period of time must place strain on any relationship. In addition, as we have seen throughout this chapter, the mega-litigation judge is typically an active participant in discussions about the

\footnotetext{
228 Bell Group Ltd (in liq) v Westpac Banking Corporation (2004) 208 ALR 491, 500 [35].

229 Interview with Chief Justice Wayne Martin (Perth, 6 March 2013); Interview with Justice David Bleby (Adelaide, 16 February 2012); Interview with Justice David Harper (Melbourne, 19 November 2012); Interview with Justice Robert McDougall (Sydney, 6 June 2012); Interview with the Honourable Neville Owen (King's Park, WA, 5 March 2013); Interviews with Participants D, E and G.

230 Interview with Justice David Bleby (Adelaide, 16 February 2012); Interview with Participant E.

231 Owen J remarked that the technology used in the Bell Group trial 'tends to develop a mind of its own and its response time resembles that of a teenager called to emerge from his or her bed on a school morning': Bell Group Ltd (in liq) v Westpac Banking Corporation (2004) 208 ALR 491, 525 [172]. At 54-6.
} 
direction of the case from an early stage. There is, therefore, a long-running relationship between judge and lawyers throughout the life of a mega-litigation matter. As Neville Owen's reflections illustrate, this relationship is as vulnerable to tensions as any other:

[In Bell Group] there were probably 25 or 30 different counsel who addressed at some stage during the trial or took some witnesses. It's inevitable that there will be conflict between bench and bar from time to time. An individual counsel may feel very strongly about a particular area or a particular issue or a particular approach, and you rule against them, and you rule against them again, and you rule against them again, and they get touchy. That's hard enough in any trial. But in this mega-litigation it becomes a real issue. You've got to be so careful to try and keep everyone on side. ${ }^{233}$

Tension between judge and counsel can not only hamper the ability of the judge to manage the case efficiently; it can also lead to allegations of bias ${ }^{234}$ and threats by lawyers to cease acting. ${ }^{235}$ One interview participant nominated 'the management of

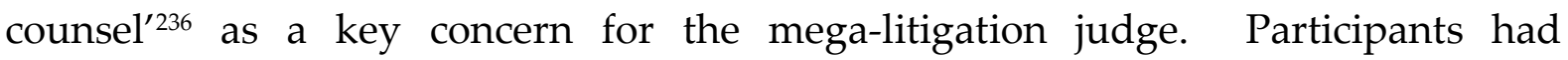
developed some imaginative techniques for dealing with these interpersonal issues. During the Bell Group trial, Neville Owen hosted an annual end of year function to which all legal representatives for all parties were invited:

Whether they came or not was up to them, but from the articled clerks and the paralegals through to the silks, the only stipulation was that I'm not going to do it unless there are representatives of all sides. And that was successful because you'd see they' $d$ be in their own groups for the first 15 minutes but then a couple of wines or a couple of beers under their belts and they'd start to mingle. And I think that was very beneficial. ${ }^{237}$

Owen also prided himself on managing relationships within the court room:

I think I got the best out of counsel. You only do that by not putting them offside. You've still got to be firm of course, because that is one of the big

\footnotetext{
233 Interview with the Honourable Neville Owen (King's Park, WA, 5 March 2013).

234 See IOOF Australia Trustees Ltd $v$ Seas Sapfor Forests Pty Ltd (1999) 78 SASR 151, in which it was argued that the attitude of an interventionist case managing judge manifested hostility towards one of the parties. The argument that this amounted to an appearance of bias was unsuccessful.

235 In the Centro litigation, lawyers for one party considered withdrawing from the case after the trial judge said she may make costs orders against solicitors if a particular line of argument were pursued: Nick Lenaghan, 'Threats to Lawyers in Centro Case', Australian Financial Review, 18 April 2012, 49.

236 Interview with Participant A.

237 Interview with the Honourable Neville Owen (King's Park, WA, 5 March 2013).
} 
differences between mega-litigation and ordinary litigation, that the chances of you falling out with counsel are greater. It makes life very tough if that happens. And the same as between counsel. ... If they started to bicker across the bar table I would stamp on it immediately by saying 'look, my job's hard enough as it is. It's made even harder with you people bickering and sniping at one another across the bar table. Stop it.' It was happening early in Bell, ... but it stopped ... because counsel knew that I was serious, I just didn't like it. It was better for them just to mutter under their breath and take it outside if they wanted to. ${ }^{238}$

Other participants also emphasised the role of the judge in creating a 'culture of cooperation rather than a culture of confrontation' ${ }^{239}$ between the parties. Robert McDougall described his task in one mega-litigation matter as 'getting parties who don't really like each other a great deal to co-operate in producing a dispute resolution process that will get them to the end of the track' ${ }^{240}$

Obviously I can give directions and they're stuck with it ... But getting them to come to agreement is a much better way of doing it. ... I discuss it with them, I don't just say 'this is what I'm going to do' - and I am prepared to listen and change and adapt a procedural solution into which everyone's had input. I've got what I want, which is that efficient breaking up of the issues. They've got what they want, which is a way towards finding who wins and who loses. ${ }^{241}$

A number of interview participants had changed the physical setting of hearings in order to defuse the tension between parties. Ray Finkelstein explained that, when taking expert evidence in the way explained earlier, ${ }^{242}$ he made sure it happened around a table in a meeting room rather than in a courtroom, 'because I wanted to change the atmosphere. ${ }^{243}$ Several participants routinely held case management conferences in mega-litigation outside the courtroom: 'an informal setting with [the judge] sitting down, cup of coffee, talking to everyone around the table'. ${ }^{244}$ Malcolm Lee explained the advantages of the 'round table' management conference:

It allows the judge to perhaps offer more than he'd be able to offer in an open court situation. It's a much more informal relationship with counsel. I suppose it has some similarity to a mediation process, without it being mediation. It is a vehicle in which the attention of the parties can be drawn to the areas of the

\footnotetext{
238 Interview with the Honourable Neville Owen (King's Park, WA, 5 March 2013).

239 Interview with the Honourable Michael Black AC QC (Melbourne, 22 November 2012).

240 Interview with Justice Robert McDougall (Sydney, 6 June 2012).

241 Interview with Justice Robert McDougall (Sydney, 6 June 2012). McDougall also referred, in this context, to the usefulness of the 'overriding objective' in s 56 of the Civil Procedure Act 2005 (NSW) - as to which, see Chapter 7 at 115-18.

$242 \quad$ At $188-9$.

243 Interview with the Honourable Ray Finkelstein QC (Melbourne, 21 November 2012).

244 Interview with Participant D.
} 
pleadings that should be regarded as peripheral, and seeing that the cardinal points are those to which the directions are being given to get that ready for trial. That's much more difficult to do in an open court directions hearing, and particularly if it's one of a number of matters that are listed in that directions day or before court starting on another day. ... You can exercise much more discipline in relation to counsel's approach than would be the case if it was in open court directions. ${ }^{245}$

Wayne Martin frequently uses round table 'strategic conferences' to create a more 'collegiate' atmosphere:

I think as soon as you hold it in a courtroom, people adopt an adversarial position. They assume that somebody will get up and make all their argument, and advance their position, as forcefully as they can. And then somebody will get up and respond to that, denying what's been said and then putting their own position. And so you just immediately get into this adversarial environment. If you're sitting around a table, and you raise issues, people can speak after each other, ... go back and forward, back and forward, back and forward. The main advantage, I think, is that when you're around a table, the culture I try and engender is that because it's a more collegiate environment, it's a more collegiate atmosphere. ... What I say at the strategic conference is that we're all here because we all have a common problem. The common problem is - how are we going to resolve this dispute as quickly and effectively as we can, consistent with the interests of justice. And that is the common task in which we are all engaged. We all have that common objective. We might see different ways of achieving that objective, but we have that common objective, and then use that as a basis for moving forward as collegiately as we can and as [non]-adversarial as we can. ... And it actually does work. I use conference rooms as often as I can in lieu of court rooms. ${ }^{246}$

The use of such non-traditional techniques reflects the fact that the task of the megalitigation judge is not confined to finding facts and applying the law. There is a human dimension to the role that calls for non-legal skills and techniques.

\section{CONCLUSION}

This chapter has presented an overview of the procedural techniques judges use in mega-litigation. It has demonstrated how the characteristics of the mega-litigation judge identified in Chapter 8 translate into practice. Active case management is crucial. This management is not confined to supervising procedural matters; the judge is involved in defining the substantive issues at the heart of the dispute. From the definition of these issues, subsequent management decisions flow. The judge

\footnotetext{
245 Interview with the Honourable Malcolm Lee QC (Fremantle, 6 March 2013). 
plays an active part in deciding exactly how and when the issues are to be determined. In addition, judges in mega-litigation are flexible in moulding traditional procedures to the needs of each case, and creative in inventing new ones. These characteristics all reflect an acceptance that civil procedure is not solely about doing justice between the parties: public justice, public efficiency and party efficiency are also legitimate goals. The mega-litigation employs active, flexible and creative means in order to pursue these goals. At the same time, mega-litigation judges are acutely conscious of the need to be fair. At times - for example, when considering whether to limit cross-examination or submissions - this has curtailed the pursuit of efficiency.

The techniques covered in this chapter are not unique to mega-litigation. They are consistent with broader developments outlined in Chapters 6 and 7: the rise of case management and the migration of control over process from the parties to the judge. While mega-litigation may not call for a completely different approach to procedure, it does require judges to make use of the full range of procedural tools at their disposal, to push the boundaries of active case management, and to experiment with new procedures. In mega-litigation, the procedural trends present in civil litigation generally are seen at their greatest intensity.

The central question in this thesis is how judges reconcile the aims of justice and efficiency in mega-litigation. How does the overview of procedural techniques in this chapter help to answer this question? Many of the techniques are directed towards improving efficiency by reducing the time spent on matters not central to the dispute. Many of them involve using creative and flexible means to design better ways of dealing with mega-litigation. Chapter 2 introduced the proposition that efficiency need not be antithetical to justice. ${ }^{247}$ The creative, active, flexible approach of mega-litigation judges may be non-traditional and may mean that the parties no longer have control over the process. But this approach, as manifested in the techniques outlined in this chapter, offers a way of improving efficiency without compromising justice.

Some of the techniques outlined in this chapter - for example, curtailing objections to evidence and controlling the reception of expert evidence - do restrict the parties' ability to put their case before the court in the way they choose. At times, this may reflect a choice by the judge to place efficiency, and public justice, objectives ahead of justice between the parties, given that the cost to justice between the parties is 
minimal. More often, though, these techniques are evidence of realignment in the roles of the parties and the court. Judges have taken control of expert evidence because they have found the parties do not present the evidence in a way that the court finds useful in determining the issues. The parties lose the freedom to conduct litigation in the way they choose, but they do not lose the right to have the disputed issues determined by a court. ${ }^{248}$

In Chapter 10, the final substantive chapter of this thesis, I explore in greater depth the ways in which judges in mega-litigation reconcile the aims of justice and efficiency. This final chapter draws on the development, in Chapters 8 and 9, of a 'thick description' of the work of the mega-litigation judges. 


\section{CHAPTER 10: JUSTICE AND EFFICIENCY IN MEgA-Litigation}

\section{INTRODUCTION}

Intuition is like reading a word without having to spell it out. ${ }^{1}$

This is the final substantive chapter of this thesis. Using the foundations laid and findings made in previous chapters, this chapter offers three answers to the central question of the thesis: how do judges reconcile the demands of justice and efficiency in mega-litigation? The three answers are, first, that judges use innovative means to achieve both efficiency and justice; secondly, that a 'laser sharp' ${ }^{2}$ focus on the issues promotes efficiency without diminishing the quality of justice; and, third, that any conflict between efficiency and justice is likely to be resolved by recourse to the judges' expert intuition.

Importantly, all three answers involve taking efficiency seriously. This study does not support a conclusion that justice between the parties is the only aim of civil procedure. On the contrary, the aims of public justice, public efficiency and party efficiency constantly influence the way judges manage mega-litigation. In addition, my answers indicate that judges take upon themselves responsibility for the efficiency of mega-litigation. It would have been possible for interview participants to describe themselves as powerless to push back against resolutely adversarial lawyers. They did not. Participants could have taken the view that it was for Parliament or law reformers to bring about procedural reform, while courts got on with the job of doing justice according to law. They did not. The interview data, together with other sources relied upon, indicate that judges in mega-litigation can, and do, use procedural techniques to pursue goals beyond that of doing justice between the parties.

As foreshadowed in Chapter 2, the aims of justice and efficiency can be complementary. Sections II and III of this chapter identify two ways in which judges in mega-litigation improve efficiency without compromising justice at all: by innovation and by using active case management to focus on the real issues in each case. While these are important ways of giving effect to the multiple aims of civil procedure, they do not eliminate all instances of tension between those aims. Therefore, section IV of this chapter revisits some of the possible ways of reconciling justice and efficiency which were introduced in Part II of the thesis. I consider whether the court rules and High Court authorities discussed in Chapter 7, or the

Agatha Christie, Murder at the Vicarage (1930) ch 11.

Interview with the Honourable Michael Black AC QC (Melbourne, 22 November 2012). 
theories outlined in Chapter 5, can help mega-litigation judges resolve the tension between justice and efficiency. Each of these possibilities leaves substantial scope for the application of the judge's own intuitive judgment. I argue that judges' expert intuition is one of the most important tools used to reconcile the tension between justice and efficiency in mega-litigation.

\section{INNOVATION}

One of the answers to the question of how judges reconcile the aims of justice and efficiency in mega-litigation has already become apparent in the last two chapters. Chapter 8 highlighted the creativity that is characteristic of the mega-litigation judge. Mega-litigation judges are constantly looking for new ways of improving procedure. In Chapter 9 we saw multiple examples of procedural innovation. Judges had experimented with new, more targeted approaches to discovery; ${ }^{3}$ division of cases into separate issues; ${ }^{4}$ the use of referees; ${ }^{5}$ streamlined expert evidence; ${ }^{6}$ and the use of technology. ${ }^{7}$ These innovations appear to be driven by the conviction that there are ways of making procedure both more efficient and more conducive to doing justice between the parties. The developments in expert evidence, ${ }^{8}$ for instance, make the evidence more useful to the court and also take up less court time.

Procedural innovation has enabled judges to improve both efficiency and justice in mega-litigation. Is anything lost as a result of innovation? The compromise, in the innovations considered in this thesis, seems to be that the parties lose the right to control the litigation. No longer are the parties entitled to present their case in any way they choose; the court has much more control over the process. As discussed in Chapters 6 and 7, this is not unique to mega-litigation. The shift in responsibility for the progress of litigation from the parties to the court has been a characteristic of the case management era, and is seen to an even greater degree in mega-litigation. Arguably, this is not a loss but rather a progression in the way we think about the purpose of civil procedure. If, as argued throughout this thesis, procedure serves the aims of efficiency (for both the parties and the public) and public justice, as well as justice between the parties, then it is appropriate for the court to assume greater control over procedure.

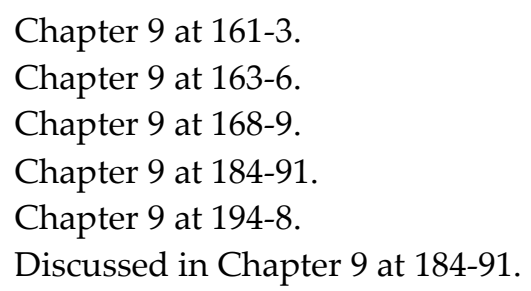


The adventurous innovations of mega-litigation judges may raise issues of compatibility with Chapter III of the Constitution. As explained in Chapter $7,{ }^{9}$ the 'due process' principle places some restrictions on court procedure. An innovation involving a radical departure from the methods that have characterised the judicial process in the past may run the risk of compromising the court's constitutional character. The extent of the 'due process' principle remains unclear. However, it appears flexible enough to allow the rules of procedures and evidence to evolve. ${ }^{10}$ The 'due process' principle is most likely to be infringed when a procedure involves a denial of procedural fairness, ${ }^{11}$ or an unacceptably close relationship between the judiciary and the executive. ${ }^{12}$ As emphasised in Chapter $8,{ }^{13}$ participants were careful to uphold their obligations to provide procedural fairness to the parties. Procedural innovations of the kind discussed in Chapter 9 do not, generally speaking, compromise the independence of the judiciary because they are innovations introduced by courts themselves, rather than being forced on courts by Parliament or the Executive. While the constitutionality of any given procedure will turn on the facts of the situation, it seems that the sort of innovations adopted by judges in mega-litigation are unlikely to offend Chapter III of the Constitution.

\section{FOCUS ON THE REAL ISSUES}

As well as creating new procedures and pushing existing procedures to their limits, judges can seek to achieve both justice and efficiency in mega-litigation by ensuring that the real issues in dispute are identified early and focussed upon throughout the litigation. As explained in Chapter 8, ${ }^{14}$ assisting parties to identify and narrow the issues is one of the most important tasks of the case managing judge in megalitigation. Focusing on the real issues in dispute prevents waste. Participants saw it

At 98-106.

10 See Commonwealth $v$ Melbourne Harbour Trust Commissioners (1922) 31 CLR 1, 12 (Knox CJ, Gavan Duffy and Starke JJ), 17 (Isaacs J); Williamson v Ah On (1926) 39 CLR 95; Nicholas $v$ The Queen (1998) 193 CLR 173, 188-9 (Brennan CJ), 202-3 (Toohey J), 225 (Hayne J), 232 (Gummow J), 260 (Kirby J), 273 (Hayne J). See also Sarah Murray, The Remaking of the Courts: LessAdversarial Practice and the Constitutional Role of the Judiciary in Australia (Federation Press, 2014). Murray concludes that a range of procedural innovations, including case management, drug courts and judicial mediation, are likely to be constitutionally permissible, while arguing that greater clarity in the applicable constitutional standards is required.

11 See the discussion of the centrality of procedural fairness to the due process principle in Chapter 7 at 102-3 and 104-6.

12 See, eg, Kable $v$ Director of Public Prosecutions (NSW) (1996) 189 CLR 51, 116-9 (McHugh J); Fardon v Attorney-General (Queensland) (2004) 223 CLR 575, [219] 655-6; International Finance Trust Company Ltd $v$ New South Wales Crime Commission (2009) 240 CLR 319, 354; cf Gypsy Jokers Motorcycle Club Inc v Commissioner of Police (2008) 234 CLR 532. 
as part of their role to avoid the parties spending their time and the court's time on irrelevant issues or unhelpful procedures:

It's the role of the judge, in my view, to try and make courts repositories of accessible justice according to law. That's what we should do. And that means, to put it bluntly, getting rid of all the bulldust and getting sharp focus on issues. ${ }^{15}$

'Now that I've seen your 200 page statement of claim and your 90 page defence, what are the real issues? ... Cut to the chase, what are the real issues?'16

[In mega-litigation], even though issues are huge to begin with, as time goes by the thinking becomes more and more refined, and huge slabs of those cases are often consigned to the dustbin. ... Murray Gleeson described the role of the modern judge as $90 \%$ garbage disposal, which is true. ${ }^{17}$

[Judges in a docket system] will all have had experience in pointing out at an early stage of litigation, in one way or another to a party, 'this is rubbish'. ${ }^{18}$

There are lots of ways in which a judge can...manage cases by reducing their length. They cannot reduce their legal complexity...but they can get rid of unnecessary evidence and get rid of hopeless legal argument. ${ }^{19}$

People can be persuaded to give up useless parts of the case..$^{20}$

It's the issue identification which is absolutely critical. ${ }^{21}$

This 'laser sharp identification of the real issues' 22 provides a crucial insight into the way in which mega-litigation judges reconcile the demands of justice and efficiency. Focus on the real issues facilitates efficiency measures of the kind outlined in Chapter 9. Discovery becomes more targeted; the range of questions for experts is limited and refined; issues suitable for separate determination can be isolated; the structure of the trial can be built around the real issues; the admission of documentary evidence can be limited to that which is truly relevant. Decisions about whether to place limits on evidence or argument can more readily be made when the judge fully understands the importance of the relevant evidence or argument. Parties can be encouraged to dispose of the parts of their case that the judge identifies as 'rubbish'.

\footnotetext{
15 Interview with the Honourable Michael Black AC QC (Melbourne, 22 November 2012).

16 Interview with Chief Justice Wayne Martin (Perth, 6 March 2013).

17 Interview with Participant A.

18 Interview with Participant G.

19 Interview with the Honourable Ray Finkelstein QC (Melbourne, 21 November 2012).

20 Interview with Participant $\mathrm{H}$.

21 Interview with Participant E.

22 Interview with the Honourable Michael Black AC QC (Melbourne, 22 November 2012).
} 
Focus on the issues means that these efficiencies are achieved without compromising justice. The mega-litigation judge who holds parties strictly to the real issues does not believe that they are refusing to consider relevant evidence, or preventing the parties from putting forward arguable issues. Instead, they are jettisoning unnecessary material which would not assist the judge to decide the case on its merits. In his judgment in the $C 7$ case, Sackville J criticised the parties for insisting on bringing in material that was not directly related to the issues in the case:

The parties in effect invited me to undertake a kind of royal commission into the comparative attributes and deficiencies of Fox Sports and C7. I said during the hearing that I failed to see the point of this exercise. My scepticism did not deter the parties from referring me to a vast amount of material relating to the merits or demerits of each service, the bulk of which I regard as largely irrelevant to the issues in this case or simply unhelpful. ${ }^{23}$

If anything, eliminating the 'rubbish' enhances the judge's ability to do justice in the case. The case is presented in a more focused way, and the truly important issues are agitated in full. As explained earlier in this thesis, the intellectual effort required to absorb and synthesise an overwhelming amount of material is a major challenge for the mega-litigation judge. ${ }^{24}$ Justice Robert McDougall spoke about his concern that he might 'lose sight of' an issue in complex litigation:

There comes a point at which I think there are just so many complexities that you can't [keep track of all the issues]. ... In a fairly small case you can miss something. In a big case the prospects of missing something are greater. And for all that the computerised transcripts and documents help you recover things, they can't always help you find the missing piece. And in a smaller case, too, ... if you're reserving your judgment [you can] read or re-read the relevant parts of the evidence. In a six month hearing, it's not really possible to do that, you just can't spend the time reading six months of transcript, not to mention the underlying statements and documents and things. ${ }^{25}$

In his judgment in Bell Group, Owen J also reflected on the difficulty of dealing with every issue in a dispute of these proportions:

I am reminded of the tag line to the 1948 film The Naked City: 'There are eight million stories in the Naked City ... this has been one of them'. There are literally hundreds of 'stories' (individual issues and disputes) raised within 10,000 or so pages of written closing submissions on the subordination issue. I have tried to cover as many of the material issues ... as I could identify. Hidden away

\footnotetext{
$23 \quad$ Seven Network Ltd v News Ltd [2007] FCA 1062, [2607].

$24 \quad$ See Chapter 3 at 34-5 and Chapter 4 at 42.

25 Interview with Justice Robert McDougall (Sydney, 6 June 2012).
} 
somewhere in the submissions there might be one or two (or eight million) 'stories' that I have missed. I have done my best. ${ }^{26}$

Clearing away unnecessary material makes the judge's mental task much more confined, thus reducing the possibility of error. One interview participant put it succinctly: 'less issues, less risk of error' ${ }^{27}$

The role of the mega-litigation judge in helping the parties to define the issues is open to criticism. Reasonable minds may differ on what the real issues in a given legal dispute are. Lawyers may not always agree with judges about what the real issues in the case are. ${ }^{28}$ The judge may seize upon an issue which the parties' lawyers did not consider crucial; an issue that the lawyers think central might, in the judge's opinion, be peripheral. If this is so, the lawyers can be forgiven for framing the case in terms that are, with hindsight, too wide.

A more fundamental criticism of the highly active managerial judging style in which judges assist the parties to narrow the issues is that it is inappropriate for a judge in an adversarial system to act in this way. In Chapter 6 I touched on some criticisms of case management, including the point that close judicial involvement in the pretrial stages of a case strips judges of the distance and impartiality that are the hallmarks of adversarial justice. ${ }^{29}$ This is not solely an academic question; some aspects of civil procedure are, as explained in Chapter $7,{ }^{30}$ constitutionally protected. If mega-litigation judges step outside their constitutional boundaries, they run the risk that procedural steps will be set aside on appeal on constitutional grounds. ${ }^{31}$

A response to this criticism is that the process of judicial issue identification described in this thesis is not one on which the judge imposes their assessment of the case on the parties. On the contrary, as explained in Chapter $8,{ }^{32}$ the process of issue identification is one of dialogue with the parties. While participants varied in the degree of force with which they expressed their views about the issues, ${ }^{33}$ most said

26 Bell Group Ltd (in liq) v Westpac Banking Corporation (No 9) (2008) 39 WAR 1, 508 [4242].

27 Interview with Participant E.

28 It is also possible that the same case may strike different judicial minds in different ways: see ED Elliott, 'Managerial Judging and the Evolution of Procedure' (1986) 53 University of Chicago Law Review 306, 316-17.

29 At 94-5, referring in particular to Judith Resnik, 'Managerial Judges' (1982) 96 Harvard Law Review 374.

$30 \quad$ At 98-106. See also the discussion in this chapter at 206.

31 For an example of a decision being set aside because of an unconstitutional procedure, see Bass v Permanent Trustee Co Ltd (1999) 198 CLR 334.

$32 \quad$ At $135-7$.

33 See 136-7. 
they would not prevent a party from arguing an issue, even if the judge thought the argument hopeless. In this respect, the tendency of mega-litigation judges towards robust case management was tempered by their acute concern for fairness. ${ }^{34}$

Another response to these criticisms is that there has never been a single ideal model for the role of the judge in civil procedure. At some periods in the past, the judicial role has been characterised by the hands-off, 'cuckoo clock judge' approach ${ }^{35}$ which leaves almost every aspect of the progress of litigation in the hands of the parties. But this has not always been the case. On the contrary, as Chapter 6 illustrates, the role has been notably malleable, with a series of reinventions occurring over the past 140 years. The judge's role in civil procedure evolves to meet the exigencies of the times. The shift in control from parties to judge can be seen as a natural part of this evolution.

This does not mean there is no fixed content to the role of the judge. The constitutional 'due process' principle introduced in Chapter 7 places limits on the extent to which the judicial role in civil procedure can be changed. As suggested in that chapter, the most significant effect of the due process principle is to entrench the rules of procedural fairness. This, in itself, is a flexible standard; the rules of procedural fairness vary according to the circumstances of each case. ${ }^{36}$ Further, constitutional protection of the institutional characteristics of courts tends to focus on substantive values - such as independence, impartiality and fairness - rather than on preserving particular approaches to procedure. In North Australian Aboriginal Legal Aid Service v Bradley, ${ }^{37}$ Gleeson CJ said of the constitutional requirement of judicial independence:

Within the Australian judiciary, there are substantial differences in arrangements concerning the appointment and tenure of judges and magistrates, terms and conditions of service, procedures for dealing with complaints against judicial officers, and court administration. All those arrangements are relevant to

$34 \quad$ See Chapter 8 at $144-9$.

$35 \quad$ See Chapter 8 at 137.

$36 \quad$ Russell $v$ Duke of Norfolk [1949] 1 All ER 109, 118; $R v$ Commonwealth Conciliation and Arbitration Commission; Ex parte The Angliss Group (1969) 122 CLR 546, 552 (Barwick CJ, McTiernan, Kitto, Taylor, Menzies, Windeyer and Owen JJ); Mobil Oil Australia Pty Ltd v Federal Commissioner of Taxation (1963) 113 CLR 475, 504 (Kitto J); National Companies and Securities Commission v News Corporation Ltd (1984) 156 CLR 296, 311-12 (Gibbs CJ), 320 (Mason, Wilson and Dawson JJ); Kioa $v$ West (1985) 159 CLR 550, 613 (Brennan J); Mark Aronson and Matthew Groves, Judicial Review of Administrative Action (Lawbook Co, $5^{\text {th }}$ ed, 2013), 493-4 [8.20]; Harry Woolf, Jeffrey Jowell and Andrew Le Sueur, De Smith's Judicial Review (Sweet \& Maxwell, 6 ${ }^{\text {th }}$ ed, 2007), 351 [6-056]; Paul Craig, Administrative Law (Sweet \& Maxwell, $7^{\text {th }}$ ed, 2012), 364-5 [12-023]. 
independence. The differences exist because there is no single ideal model of judicial independence, personal or institutional. There is room for legislative choice in this area... ${ }^{38}$

Similar observations might be made about the constitutional requirement of procedural fairness. There are many ways for a judge to provide a fair hearing and to remain impartial. The 'cuckoo clock' method is one way of doing so; but it is not the only way. As we saw in Chapter 8, mega-litigation judges are acutely aware of their procedural fairness obligations; but they did not see these obligations as incompatible with adopting inventive procedures, or playing an active role in refining the issues. While this is not the place for a full analysis of exactly what the constitutional 'due process' principle requires, my view is that the principle is flexible enough to accommodate the active, flexible, creative, issue-refining megalitigation judge. ${ }^{39}$

By adopting a highly active managerial approach, judges in mega-litigation can assist the parties to narrow the issues and thereby achieve maximum efficiency while ensuring that justice between the parties is done. This role for the judge is not uncontroversial. Nor is it a role to which every judge is suited. Yet the role is defensible and even, when considered in the context of the evolution of civil procedure, necessary.

\section{RESOLVING THE TENSION}

Until this point of the chapter, I have been discussing ways of giving effect to both efficiency and justice in mega-litigation. In many (probably most) instances, an apparent conflict between justice and efficiency can be resolved by one of the means identified in sections II and III of this chapter: procedural innovation, or sharp focus on the issues. In some instances, however, there will be real tension between the aim of doing justice between the parties, and the other aims of civil procedure - public justice, and efficiency for the parties and the public. In this section of the chapter, I examine the ways in which this tension is resolved.

Part II of this thesis canvassed some options for reconciling justice and efficiency in civil procedure. Chapter 5 considered theoretical approaches to the problem. Chapters 6 and 7 explained how successive generations had approached the challenges of civil procedure in practice. Now, armed with a rich understanding of

Ibid 152 [3].

See Murray, above n 10, ch 4 (explaining that, while case management regimes are likely to be constitutional, there is uncertainty about the extent to which individual discretionary decisions will infringe Chapter III). 
the role of the mega-litigation judge (developed in Chapters 8 and 9), I will consider the extent to which these principles and theories help mega-litigation judges to reconcile the aims of justice and efficiency. I begin by analysing the part played by court rules and legislation (particularly the 'overarching purpose' provisions) and by High Court authorities on procedure. Next, I consider whether theories about procedure - specifically, the four theories introduced in Chapter 5 - can help to make these decisions. I argue that these sources, while potentially helpful, provide only general guidance and leave a wide margin for the exercise of judicial discretion. In the final part of this section I argue that the decisive factor in reconciling the tension between justice and efficiency in many procedural decisions in megalitigation is the expert intuition of the individual judge.

\section{A Rules and Procedural Legislation}

I touched on the role of court rules and procedural legislation in Chapter 8, when discussing flexibility as a characteristic of the mega-litigation judge. ${ }^{40}$ As explained there, several participants reported that they effectively made their own rules in mega-litigation. Chief Justice Wayne Martin, when asked whether the traditional rules of civil procedure fulfilled their purpose, replied 'No. We have effectively abandoned them, in this Court, in favour of a docket-based case management system.' $^{41}$ This view was not unanimous. Justice David Bleby found that the rules proved to be well-adapted to application in the mega-litigation situation, and were certainly not a hindrance. ${ }^{42}$

For others, the strength of the rules lay in their flexibility. ${ }^{43}$ Court rules commonly contain a provision allowing the court to dispense with compliance with the rules, ${ }^{44}$ and to make any directions appropriate in the interests of justice. ${ }^{45}$ This means that conflicts between efficiency and justice cannot always be resolved by reference to the specific rules that apply to the dispute. In a difficult case, it is up to the judge to decide where the interests of justice lie. The rules may suggest, but rarely dictate, a particular outcome.

\footnotetext{
$40 \quad$ At $142-3$.

41 Interview with Chief Justice Wayne Martin (Perth, 6 March 2013).

42 Interview with Justice David Bleby (Adelaide, 16 February 2012).

43 See the discussion in Chapter 8 at 142-3.

$44 \quad$ See, eg, Federal Court Rules 2011 (Cth) r 1.34; Court Procedures Rules 2006 (ACT) r 6; Supreme Court (General Civil Procedure) Rules 2005 (Vic) r 2.04.

$45 \quad$ Federal Court Rules 2011 (Cth) r 1.32; Court Procedures Rules 2006 (ACT) r 1401; Uniform Civil Procedure Rules 2005 (NSW) r 2.1; Supreme Court Rules (NT) r 34.01; Uniform Civil Procedure Rules 1999 (Qld) r 367; Supreme Court Civil Rules 2006 (SA) r 117; Supreme Court (General Civil Procedure) Rules 2005 (Vic) r 34.01.
} 
Many participants spoke of the importance of 'overarching purpose' provisions in court rules. As explained in Chapter 7,46 these provisions typically exhort the judge, parties and legal representatives to resolve the dispute in a way which is just, quick and cheap. Participants spoke favourably about these provisions. ${ }^{47}$ For one Federal Court judge the overriding objective set out the 'playing field' on which the litigation was to take place:

We've got 37M. Our playing field is set. We know that there's an obligation on the Court, on the practitioners, and on the parties to conduct litigation in a particular way. And we all know that at the end of the day there has to be a just result, we've just got to get there in the most efficient and economic way possible. And so that means under our rules we can do just about anything we like in order to achieve that. And everyone says, 'well, isn't that a bit open-ended?' Well, no, it's not, because the playing field is set. And if we do something outside the playing field we get into trouble. ${ }^{48}$

On this view, the overarching purpose provisions help to ensure fairness. It is not unfair to take action on efficiency grounds if that action is consistent with the overriding objective and all parties understand, from the outset, their obligations under the Rules.

One participant said that the overarching purpose had made him 'more confident in engaging in procedural limitations which may affect the parties', ${ }^{49}$ while another said that, had the overarching purpose been in the legislation at the time he presided over a mega-litigation matter, it 'would have given more encouragement to me ... [to take] a rather bolder approach.' 50 Participants noted the effect of the overarching purpose provisions on breaking down party control of proceedings:

Previously we would have taken the view that if a party comes along and says to us 'we've got to have a fair trial' we'd invariably grant adjournments, allow amendments, let them have more time in terms of interlocutory work. The [overarching purpose] gives us a weapon to limit the parties' utilisation of the fair trial argument. I think we've just got to be satisfied that there is going to be a fair trial, and not always bend to a party's assertion. ${ }^{51}$

$46 \quad$ At $115-16$.

47 Interview with the Honourable Michael Black AC QC (Melbourne, 22 November 2012);

Interview with the Honourable Ray Finkelstein QC (Melbourne, 21 November 2012); Interview with Justice Robert McDougall (Sydney, 6 June 2012); Interviews with Participants A, B, D E, F, G and $H$.

48 Interview with Participant E.

49 Interview with Participant D.

50 Interview with Participant G.

51 Interview with Participant D. Participant B also noted that the provisions were useful because they made it clear 'that it's not just a matter of "because one party wants it, it should happen"'. 
Some participants said the overarching purpose provisions were important because they placed obligations on practitioners:

[The overarching purpose] has been important in that it casts direct obligations on the practitioners. And of course they are motivated by fear in relation to that, as they should be..$^{52}$

Now that you've got legislative endorsement of case management, the overriding purpose stated, obligations on the parties to assist, and you can not merely draw [the overriding purpose] to their attention but make orders requiring them to do a whole range of things, not least imposing costs sanctions upon them. ${ }^{53}$

Most people are conscious that under s 56 of the Civil Procedure Act, they have obligations to the court to assist in the just, quick and cheap resolution of the real issues in dispute. And if you keep on saying that long enough they'll come around. 54

Section 37N [of the Federal Court of Australia Act 1976 (Cth)] says the parties and the lawyers each have duties to cooperate, to assist the Court to achieve the overarching purpose. So you can look at them and say 'you've both got duties. It's no good just ... saying "oh, it's up to them to do something". You've both got to cooperate in working out these issues.' 55

One participant emphasised the origins of the overarching purpose provision in the Federal Court: it first appeared as a practice note, was then incorporated into the Court Rules, and finally, at the request of judges of the Court ('we asked for that legislation to go in'), was inserted into the Federal Court of Australia Act 1976 (Cth):

The common law, in any event, was probably moving that way...because that's the way judges were seeing things. ... The overarching purpose confirms quite explicitly an approach that was already being adopted. 56

Ray Finkelstein, who was involved in drafting the legislation, said that the overarching purpose expressed, in legislation, the approach he was already taking, describing the enactment of some of the statutory provisions as 'trying to get Parliament to legislate what I was doing. ${ }^{57}$ The overarching purpose, then, was not revolutionary: it reflected existing - and emerging - practices and attitudes to case management. Participants referred to the overarching purpose as 'useful', 58 as a

\footnotetext{
Interview with Participant A.

Interview with Participant G.

Interview with Justice Robert McDougall (Sydney, 6 June 2012).

Interview with Participant F.

Interview with the Honourable Michael Black AC QC (Melbourne, 22 November 2012).

Interview with the Honourable Ray Finkelstein QC (Melbourne, 21 November 2012).

Interview with Participant B.
} 
'weapon', ${ }^{59}$ a 'convenient tool', ${ }^{60}$ a 'helpful tool' ${ }^{61}$ and even a 'statutory baseball bat' ${ }^{62}$ In other words, participants seemed to view the overarching purpose less as a source of principle than as an instrument which could be used to enforce the judge's preexisting proactive, interventionist approach to procedure.

The overarching purpose provisions, then, do not provide an answer to the question of how to reconcile the aims of efficiency and justice; they merely set out the various aims of civil procedure. ${ }^{63}$ This, in itself, is important because - as one Federal Court judges pointed out - the aims are explicitly expanded beyond that of doing justice between the parties:

I think it's a useful thing to have in all civil procedure rules or provisions because it emphasises that there are values outside the immediate resolution of the case that are important to civil procedure ... Although [the overarching purpose] may sound like empty advertising, it may sound like puffery - 'this is what we'd like civil procedure to be' - it actually does embody the principle that it's not just the immediate matter and the immediate parties that dictate what might be appropriate civil procedure. And I think that is important. ${ }^{64}$

But how should a judge seek to achieve the sometimes disparate aims of the overarching purpose? Does one of the aims take priority over the others? Austin J considered this question in ASIC $v$ Rich:

The statutory duty imposed by s 56 [of the Civil Procedure Act 2005 (NSW)] is to pursue an overriding purpose containing three elements, relating to justice, speed, and cheapness or minimal expense. It seems to me, however, that two of these elements are relative concepts, while the third is an absolute. The hearing may be more or less speedy, and the case may be managed in a way that reduces costs to a greater or lesser degree, while still satisfying the statutory criteria. But the obligation to do justice is absolute; it is not to be apportioned on a sliding scale. It is unjust, not more or less unjust but simply unjust, to manage a case in a way that denies procedural or substantive fairness; say, by shutting a defendant out of presenting his or her case in answer to the plaintiff's allegations or by preventing the plaintiff from adequately cross-examining the defendants and their witnesses.

When, therefore, the statute instructs the court to administer cases in a manner that is just, quick, and cheap, in my view it is not the legislative intention that if a matter of case management will promote cheap and quick resolution, it can (or

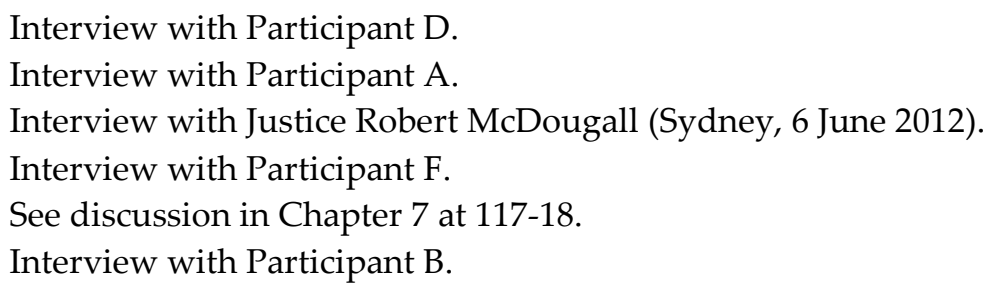


even must) be adopted although plainly unjust. Section 56, properly construed, must be taken to mean that the court is required to administer cases in a manner that promotes speedy and cheap resolution of the real dispute, provided always that what is done is just. The alternative interpretation, that justice, speed and cheapness are discretionary factors of more or less equal weight, to be juggled in case management, would amount to a statutory licence to judges to behave unjustly and inconsistently with their judicial oath, which is not an oath to do right to all manner of people so long as it is quick and cheap to do so. ${ }^{65}$

Austin J, then, construed the overriding purpose so as not to permit any diminution in the quality of justice. This approach was not strongly reflected in the interview data. As explained earlier in this thesis, ${ }^{66}$ some participants said that efficiency pressures, as well as 'public justice' considerations, meant that there must be some compromise in the standard of procedure delivered to individual litigants.

In addition, the overriding purpose provisions do not negate the need for each judge to use their intuition and experience in making procedural decisions. A Supreme Court judge summarised the position as follows:

We use [the overriding purpose] all the time, but that also is just an expression of motherhood. And so you use it as a convenient tool to enable you to manage the case efficiently. ... But ... you can have the best practice notes in the world. If you've got a poor judge it's not going to help. And you can have no practice note at all and if you've got a good judge you'll be all right. ${ }^{67}$

This raises a critical point: overarching purpose provisions do not necessarily rule out the possibility of an inefficient approach to case management. The provisions are so open to interpretation that a judge who is inclined to passivity might be able to rely on an overarching purpose provision to say that a 'just' result required the minute exploration of every marginal issue.

In sum, the overarching purpose provisions can embolden judges to be active, creative case managers. Further, they confirm that the aims of civil procedure include public justice, and efficiency for both the parties and the public, as well as justice for the parties. They have normative value in requiring judges and parties to pursue these other aims. Overarching purpose provisions are an important element of the case management system. But these provisions do not provide an answer to the question of how to reconcile the various objectives of procedure. Participants value these provisions because they are facultative rather than prescriptive: the rules

\footnotetext{
65 Australian Securities and Investments Commission v Rich (2009) 236 FLR 1, 35 [75]-[76] (emphasis in original).

66 At 57-8.

67 Interview with Participant A.
} 
help mega-litigation judges not by telling them what to do in a given situation, but by freeing them up to do whatever they believe is appropriate. Furthermore, because overarching purpose provisions leave much of the work of reconciling the various objectives of procedure up to individual judges, they leave open the possibility that a judge will choose an inefficient method of proceeding. This possibility is mitigated to some extent by the possibility that a decision that does not give effect to the overarching purpose may be overturned on appeal. We will now consider what effect the High Court's decisions on procedure have had on the reconciliation of the aims of justice and efficiency in mega-litigation.

\section{B High Court Authority}

As explained in Chapter 7, there are High Court authorities addressing the relationship between justice and efficiency in civil procedure. Between 1997 and 2009, the leading authority, JL Holdings, made it clear that justice between the parties was the 'paramount' aim of civil procedure and was not to be outweighed by case management considerations. ${ }^{68}$ In Aon, in 2009, the High Court overruled JL Holdings and endorsed an understanding of 'justice' which takes into account considerations of public justice and public efficiency. ${ }^{69}$ Expense Reduction Analysts, ${ }^{70}$ handed down in 2013, reaffirmed the Aon view that justice, in the context of civil procedure, requires those broader considerations to be taken into account. Do these High Court authorities provide clear guidance for judges faced with a conflict between efficiency and justice in mega-litigation?

The trial in ASIC $v$ Rich took place when JL Holdings was the relevant High Court authority. Aon was handed down after judgment was reserved but before Austin J handed down his judgment. In the judgment, Austin J considered whether Aon qualified the principles by which the case had been run:

[T] he changes in attitude that can be seen in Aon Risk ... to the significance of principles of case management, do not qualify the proposition that the trial judge's fundamental responsibility is to do justice in the case he or she is hearing. ${ }^{71} \ldots$

68 JL Holdings $v$ Queensland (1997) 189 CLR 146, 155. See the discussion of JL Holdings in Chapter 7 at 108-15.

69 Aon Risk Services Australia Ltd v Australian National University (2009) 239 CLR 175. See the discussion of Aon in Chapter 7 at 118-24.

$70 \quad$ Expense Reduction Analysts Group Pty Ltd v Armstrong Strategic Management and Marketing Pty Ltd (2013) 250 CLR 303, discussed in Chapter 7 at 124-6.

$71 \quad$ Australian Securities and Investments Commission v Rich (2009) 236 FLR 1, 37 [82]. 
The decisions I have taken during the hearing in this case are consistent with the principles stated by the High Court in Aon Risk, bearing in mind the court's paramount duty, acknowledged in that case, to achieve a just resolution of the proceedings. In my view any further shaving of the hearing time, for example by imposing artificial limits on cross-examination and written submissions, or by limiting the amount of preparation times for cross-examination and submissions, would have created a substantial risk that justice would not be done, given the complex and extensive nature of the evidence and the extent of the matters in issue between the parties. It has to be recognised, in my view, that however hard the judge might try, consistently with his or her fundamental duty to do justice in the resolution of the proceedings, to bring about quick and cheap resolution of the matters in dispute, some cases are just very long and costly, the length and cost being contributed to by both sides, and they have to be seen through to their conclusion. ${ }^{72}$

Austin J, then, did not appear to believe that the change in the High Court's approach to case management would have had any effect on the running of the case. His Honour did not accept that Aon would have justified any measure that placed the other aims of procedure ahead of that of doing justice between the parties.

The interviews conducted for this thesis revealed some different perspectives on the effect of JL Holdings and Aon. Participants were asked how these High Court decisions affected their management of mega-litigation. Most participants had been appointed to the bench before Aon and were thus able to comment on the effect of both decisions. Some had retired, or been elevated to an appeal court, before or shortly after Aon was decided and therefore had little experience of its effect on trial judges. There was no opportunity to ask participants about their views on the High Court's decision in Expense Reduction Analysts, ${ }^{73}$ as this decision was handed down after the interviews were completed.

The interview data reveals two distinct narratives about the effect of the High Court authorities. The first is that these cases have a significant practical effect on day to day decision-making. During the time in which it remained authoritative, JL Holdings was an impediment to active case management and efficiency measures:

Someone would quote JL Holdings ... and you'd be just about duty bound to grant an adjournment or permit an amendment. ${ }^{74}$

[JL Holdings had an effect on day to day work of trial judges] because we weren't

$72 \quad$ Ibid 37-8 [84].

73 Expense Reduction Analysts Group Pty Ltd v Armstrong Strategic Management and Marketing Pty Ltd (2013) 250 CLR 303, discussed in Chapter 7. 
able to put the same emphasis on case management as otherwise we would have done. ${ }^{75}$

JL Holdings meant that judges were not prepared to step in. Case management was relegated to what was thought to be issues of cost, and delay was a subsidiary issue. ${ }^{76}$

[JL Holdings influenced day to day decision-making] because it told us that we couldn't put case management considerations at the forefront of our dealing with procedural applications. ${ }^{77}$

[JL Holdings] was a factor, there's no question. ... There was always, at the back of my mind, there was certainly a factor that weighed with me, that ... if you took too hard a line ... if one of the parties could plausibly say that what the judge has done is too stringent, since it's denied the party the opportunity for a full and fair hearing on the issues they wish to raise, there was always a possibility that the whole thing could run off the rails. ${ }^{78}$

For participants who had this experience of JL Holdings, Aon came as a significant and welcome change, allowing judges to take control of cases and to put case management considerations ahead of the wishes of the parties. ${ }^{79}$

Other participants told a different story, suggesting that judges continued to follow their own approaches to case management regardless of the High Court authorities. One participant said JL Holdings

was used conservatively by people who didn't want things to happen in their litigation. But I think the progressive judges just went on doing it [active case management] anyway. ${ }^{80}$

Indeed, several participants observed that the 2009 decision in Aon merely aligned High Court authority with existing judicial practice:

[Aon] had no effect on the reforms in our court. We just kept on doing it. ... When Aon came in, [it] confirmed the views that we already held. ${ }^{81}$

\footnotetext{
75 Interview with Justice David Harper (Melbourne, 19 November 2012).

76 Interview with Participant $\mathrm{H}$.

77 Interview with Justice Robert McDougall (Sydney, 6 June 2012).

78 Interview with Participant G.

79 Interview with Justice David Harper (Melbourne, 19 November 2012); Interview with Justice Robert McDougall (Sydney, 6 June 2012); Interviews with Participants F, G and H.

80 Interview with the Honourable Michael Black AC QC (Melbourne, 22 November 2012).

81 Interview with the Honourable Michael Black AC QC (Melbourne, 22 November 2012).
} 
I think at the time that Aon was decided, enough judges were taking active roles in managing cases that the kind of problems that arose in [JL Holdings and factually similar cases] were no longer serious problems. ${ }^{82}$

I think we approached it, in any event, the way Aon says, in [this jurisdiction] it's basically always been like that. ${ }^{83}$

The introduction of overarching purpose provisions - which, as argued above, ${ }^{84}$ themselves reflected existing judicial practice - was seen by some as at least as important as, and certainly complementary to, the decision in Aon: 85

The change in the High Court's approach with Aon I think has just reflected what the [overarching purpose] says. So I think both put together means now we can say with some authority that enough is enough. ${ }^{86}$

The change in the law [in Aon] was of assistance but in a sense we'd gazumped it by then. The [overarching purpose] was part of the landscape ... So I don't think [Aon] affects us much. ... I think the changes to the Act were the more important thing for us. ${ }^{87}$

On the one hand, then, we see judges who felt fettered by JL Holdings and freed up by Aon. On the other we see judges who simply kept up their robust case management practices until the High Court came round to their point of view. What both groups have in common is strong disagreement with the JL Holdings principles, which made justice between the parties the 'paramount' consideration, and deprecated the role of case management. One participant said:

Everyone knew [JL Holdings] was wrong. Everyone knew it was going to be changed, and it had to be. It was old fashioned. ${ }^{88}$

Accordingly, participants felt that the multi-dimensional approach to justice adopted in Aon accorded with their own views about justice and efficiency:

I think [the view of justice set out in Aon] is undoubtedly, in the modern world, a much more appropriate approach. The fact is that the courts are battling, and I'm sure always will battle, with the need to get through the case lists. Litigants need to be heard in a timely way and I think that any small diminution in the justice dispensed in the individual case has been more than compensated by the much

\footnotetext{
82 Interview with the Honourable Ray Finkelstein QC (Melbourne, 21 November 2012).

83 Interview with Participant A.

$84 \quad$ At 214.

85 Interview with the Honourable Michael Black AC QC (Melbourne, 22 November 2012); Interviews with Participants D, E and G.

86 Interview with Participant D.

87 Interview with Participant E.

$88 \quad$ Ibid.
} 
more ready access to justice which the new procedures have allowed other litigants. ${ }^{89}$

I thought the important thing about [Aon] was to say that there is no tension between justice and, if you like, efficient case management; that they are two sides of the same coin. Whereas previously, you get the sense from JL Holdings that justice was counterposed to efficient case management. The important thing from [Aon] was 'no no, they're the same', and to me that was very important recognition that I think underpins a lot of what we've been doing anyway. So I think that was a very welcome change. ${ }^{90}$

The current state of authority permits, and even requires, case managing judges to take into account considerations of efficiency and of public justice - not just justice between the parties - when making procedural decisions. But, as with the overarching purpose, the case law may simply leave judges with the task of reconciling these multifarious considerations. For some participants, the effect of both JL Holdings and Aon was quite minimal, simply because every procedural decision turns on its facts. ${ }^{91}$ The High Court authorities provide general principles, but these are not necessarily of much help when making individual decisions:

Aon just tells you certain basic principles. Every case is so intensely different. ... So Aon plays very little role in my list. ${ }^{92}$

We get quoted the same decisions, all the time. And they are important in terms of the statements of principle therein. The actual results, of course, of individual cases are not as important because the spectrum of relevant matters to a discretionary decision is so potentially broad ... Aon, on any discretionary decision ... is endlessly quoted. So there's that as a principle, yes, [but] in Aon the result in the particular case turned on its own factual circumstances.... And the facts are always different. ... Discretionary decisions are hard I think. Inherently hard. Because they're discretionary. ${ }^{93}$

Once again, we see that even though High Court decisions can provide some very general guidance, the task of determining each procedural decision falls back on the discretion of each individual judge.

There is, perhaps, a broader lesson to be taken from the reaction of trial courts to the High Courts' decisions in JL Holdings and Aon. The High Court may be inherently

\footnotetext{
89 Interview with Justice David Harper (Melbourne, 19 November 2012).

$90 \quad$ Interview with Chief Justice Wayne Martin (Perth, 6 March 2013).

91 Interview with the Honourable Ray Finkelstein QC (Melbourne, 21 November 2012);

Interviews with Participants B and C.

Interview with Participant A.

Interview with Participant B.
} 
unsuited to making broad pronouncements about the exercise of procedural discretions. The decision in JL Holdings was out of step with the practical reality of trial courts. The decision in Aon, while welcome, reflected developments in practice and court rules already initiated by trial courts themselves. The High Court's guidance seems to have the capacity to hold back, but not advance, the evolution of civil procedure. Developments in civil procedure have been led by the day to day work of judges, not by statements of principle emanating from appeal courts. At best, the High Court's decisions (such as Aon) can facilitate this evolution. At worst (as in JL Holdings) they can stultify it. The High Court's decisions have not provided a definitive answer to the question of how to reconcile justice and efficiency in civil procedure.

\section{Theories}

So far this chapter has considered the role played by sources of law - namely, High Court authorities and court rules - in helping judges to make procedural decisions in mega-litigation. Chapter 5 of this thesis examined some of the leading theories on civil procedure: Posner's economic cost-benefit analysis; Zuckerman's balancing of cost, time and accuracy; Dworkin's right to a minimum level of procedure, based on the risk of moral harm; and Summers' plea for 'process values'. Might one of these theories provide the key to procedural decision-making in mega-litigation?

In order to investigate this question, I asked interview participants their views about each of the theories. Approximately one week before the interview, participants were provided with a one-paragraph summary of each of the theories. ${ }^{94}$ During the interview, participants were asked to respond to the theories, and specifically to comment on whether the theories had relevance in practice for a judge presiding over mega-litigation. The difficulties in compressing the theories into short summaries proved to be a limitation of this method. ${ }^{95}$ These difficulties included the generalisation of subtle distinctions and an emphasis on broad concepts. That said, overall the method was reasonably successful. Without exception, participants had read and reflected on the theories prior to the interview, with some making notes or

$94 \quad$ See Appendix.

95 The method was chosen because of the circumstances in which the interviews were conducted. It was important to provide written summaries of the theories in advance, so that participants had time to understand and reflect on the theories. Interview participants were, in general, extremely busy individuals who had agreed to take part in interviews while receiving no tangible benefits in return. Very short summaries were used because of a desire to minimise the burden of preparation on interview participants, and to maximise the chance that participants would have time to read the theories before the interview. Therefore, the brevity of the summaries was appropriate for this project. 
preparing written responses. When participants required clarification, they were able to request this during the interview, which led to a more nuanced discussion of the theories in question.

This section of the chapter presents participants' reactions to each of the four theories introduced in Chapter 5, followed by some of their more general reflections on the role of theory in procedural decision-making.

\section{Zuckerman: Three Dimensions of Justice}

As explained in Chapter 5, ${ }^{96}$ Zuckerman accepts that the aim of a procedural system is to achieve justice, but describes justice as having three dimensions: accuracy, cost and time. The aim of procedure is to achieve the 'optimal compromise' between these three dimensions. ${ }^{97}$

A number of participants said Zuckerman's theory aligned quite closely to their view of the role of a judge in mega-litigation. ${ }^{98}$ Some said they 'really like[d]' ${ }^{99}$ Zuckerman's work, with Ray Finkelstein praising his 'practical approach'. ${ }^{100}$ Two participants pointed out that Zuckerman's theory was silent on exactly how to strike the balance between the three dimensions:

I can relate to [Zuckerman's theory]. I don't have any quarrel with that. The big question is how? ${ }^{101}$

I don't know how far that gets you, to say that there are these various dimensions. Of course there are. The trick is to determine how you apply them in a particular case. ${ }^{102}$

One Federal Court judge agreed that Zuckerman's three dimensions were present in procedural law, but did not think the three dimensions were of equal significance:

What he calls rectitude or accuracy has to be the aim for me ... It would be difficult to accept a compromise on accuracy of decision in the interests of time and cost. It seems to me that accuracy would be fundamental, and time and cost

\footnotetext{
96 At $65-8$.

97 AAS Zuckerman, 'A Reform of Civil Procedure - Rationing Procedure Rather than Access to Justice' (1995) 22 Journal of Law and Society 155, 161.

98 Interview with the Honourable Michael Black AC QC (Melbourne, 22 November 2012); Interview with Justice David Bleby (Adelaide, 16 February 2012); Interview with the Honourable Ray Finkelstein QC (Melbourne, 21 November 2012); Interview with Chief Justice Wayne Martin (Perth, 6 March 2013); Interviews with Participants E, F and G.

99 Interview with Chief Justice Wayne Martin (Perth, 6 March 2013); Interview with Participant E.

100 Interview with the Honourable Ray Finkelstein QC (Melbourne, 21 November 2012).

101 Interview with Justice David Bleby (Adelaide, 16 February 2012).

102 Interview with Participant G.
} 
at a different level, or a different order of significance. I mean if you have a justice system which does not have, as its fundamental aim, to give sound decisions, I find that an odd concept. I wouldn't make them equal, for myself. ${ }^{103}$

Other participants thought that Zuckerman had omitted some important goals of procedure. Two participants cited fairness - both procedural and substantive - as a further dimension of justice:

Accuracy, time and cost. I would have also said fairness. I would have added to that. The end result is we have to produce a fair result. ${ }^{104}$

[Zuckerman's theory is] right as far as it goes. But justice is more than that ... I'm still wedded to the Rawls position that justice in the end must be fairness, and it's a question of not applying principles at the expense of fairness, there have to be principles that deliver fairness for it to be a just system. ${ }^{105}$

Another participant nominated 'acceptability' as an additional dimension of justice:

I agree that three tremendously important aspects of the court's work are accuracy, time and cost. ... Another dimension which I think may be involved, though, is acceptability: the public's acceptance of the system as producing just outcomes. And that will obviously involve the extent to which the decision is seen as being accurate - even though someone mightn't like it - and it will also involve the time taken to resolve disputes, and the cost involved. But if you don't have the public confidence in the system, then it's not doing its job. ${ }^{106}$

This concept of 'acceptability' is similar to the concept of 'public justice' used throughout this thesis. Both concepts are based on the idea that the general public, as well as the parties, have an interest in individual judicial decisions and in the maintenance of the integrity of the justice system.

Overall, Zuckerman's theory had relevance for most participants. The limitations that participants identified have been acknowledged by Zuckerman himself: ${ }^{107}$ that is, different results may be reached by placing different weighting on the three dimensions of justice. Further, as explained above, some participants thought the theory overlooked important aspects of justice.

\footnotetext{
103 Interview with Participant B.

104 Interview with Participant D.

105 Interview with the Honourable Malcolm Lee QC (Fremantle, 6 March 2013).

106 Interview with Justice Robert McDougall (Sydney, 6 June 2012).

107 See the discussion in Chapter 5 at 67-8, citing Adrian AS Zuckerman, 'Justice in Crisis:

Comparative Dimensions of Civil Procedure' in Adrian AS Zuckerman (ed), Civil Justice in

Crisis (Oxford University Press, 1999) 3, 3.
} 
Zuckerman's theory cannot provide a complete answer for judges making procedural decisions. It can, perhaps, be used to justify decisions. For example, a judge could explain a decision to limit discovery in mega-litigation by saying the 'cost' dimension of justice played an important role in the decision. But the theory does not necessarily help the judge to make the decision; that is, to dictate that the cost dimension should assume more importance than the accuracy dimension in a particular case. Ultimately, the 'three dimensions of justice' work in a similar way to the overarching purpose provisions: ${ }^{108}$ they set aspirational goals for the system, but leave ample room for judicial assessment of where justice lies in each case.

\section{Posner: Economic Analysis of Civil Procedure}

As explained in Chapter 5, ${ }^{109}$ Posner applied economic theory to procedure, arguing that procedural law ought to minimise the sum of 'error costs' - the cost of erroneous judicial decisions - and 'direct costs' - the cost of procedure for the parties and the State.

Most participants had reservations about the value of this economic analysis. Some said the exercise of ascertaining the error costs and direct costs was impractical: it was complex, time consuming, specialised work that could not feasibly be incorporated into judicial decision-making. ${ }^{110}$ Another reaction was that economic theory might offer some helpful insights, but was 'not the sole answer'111 to procedural questions. ${ }^{112}$ Some participants rejected Posner's analysis because they rejected some of the tenets of economic theory. ${ }^{113}$ Common to the latter two groups of participants was the observation that the economic analysis did not capture all the important values of a legal system:

Litigation is ... not just economics, it also involves people. And there are personal concerns which come into the balance as well. There's no simple

\footnotetext{
$108 \quad$ Discussed in Chapter 7 at 115-18 and Chapter 10 at 212-17.

109 At 68-71.

110 Interview with Justice David Bleby (Adelaide, 16 February 2012); Interview with Justice David Harper (Melbourne, 19 November 2012); Interview with the Honourable Malcolm Lee QC (Fremantle, 6 March 2013); Interview with Chief Justice Wayne Martin (Perth, 6 March 2013); Interview with the Honourable Neville Owen (King's Park, WA, 5 March 2013); Interview with Participant B.

111 Interview with Participant D.

112 Interview with Justice David Bleby (Adelaide, 16 February 2012); Interviews with Participants $D$ and $G$.

113 Interview with the Honourable Ray Finkelstein QC (Melbourne, 21 November 2012); Interview with Chief Justice Wayne Martin (Perth, 6 March 2013); Interview with Justice Robert McDougall (Sydney, 6 June 2012); Interview with Participant G.
} 
answer which you can reduce to a balancing of costs, I don't think. ${ }^{114}$

There are other values which inform legal principles, other than [economic values]. ${ }^{115}$

Expediency, reduction in cost are all admirable aims but at the end of the day we have to produce a just result for the parties. And so you don't want to lose sight of that in the context of concerns about other aspects of mega-litigation, all of which are justifiable. ${ }^{116}$

[Missing from Posner's analysis is] the fact that at the end of the day, the system of justice has to work for the people whose affairs it controls, and its outcomes have to be acceptable to the community as a whole.... The ultimate outcome of what he's saying is that the losing party has to accept that he is doing good for the community by minimising the overall expenditure on the legal system. And I don't think that's what we need to do. We need to decide cases justly. ${ }^{117}$

A justice system doesn't exist just to balance [economic factors], it vindicates rights and provides people with the protection of the law and the protection of their rights and their interests, which can't be measured in purely monetary terms. ${ }^{118}$

You have to take into account that there are values that can't readily be incorporated within an economic model ... There are many values that cannot be quantified. You simply cannot quantify in mathematical terms ... with any degree of precision so as for example to say 'well, I am prepared to forego $\$ 39.27$ worth of procedural fairness in order to get a benefit of $\$ 64$ of court time that will be saved'. There are imponderables, you can make a kind of informed, or semiinformed, assessment of the trade-offs, but in the end they involve value judgments. ... In the end you cannot avoid value judgments, you cannot avoid balancing certain matters that cannot be reduced to quantifiable terms. That I think is the caution that you've got to exercise in adopting Posner's approach. ${ }^{119}$

These remarks reveal a conviction that the judge must be concerned with justice and with the effect of their decisions on human beings. This is, of course, not surprising. But it serves to emphasise that, while interview participants generally took efficiency seriously when dealing with mega-litigation, they were equally aware of other aims of the justice system. In particular, participants recognised the benefits to both the parties and the public of a fair process and result. The responses set out above, particularly the last quote, also reflect a view that procedure involves 'imponderables' which cannot be reduced to a mathematical equation; once again,

\footnotetext{
114 Interview with Justice David Bleby (Adelaide, 16 February 2012).

115 Interview with the Honourable Ray Finkelstein QC (Melbourne, 21 November 2012).

116 Interview with Participant D.

117 Interview with Justice Robert McDougall (Sydney, 6 June 2012).

118 Interview with Chief Justice Wayne Martin (Perth, 6 March 2013).

119 Interview with Participant G.
} 
we see an acknowledgment of the role of immeasurable value judgments in judicial decision-making. Posner's own, more recent, work acknowledges the importance of such judgments. ${ }^{120}$

Some participants did report that the economic approach had some resonance with their own experience. One Federal Court judge agreed with Posner's basic premise of balancing costs. ${ }^{121}$ Neville Owen said that Posner's theory 'does strike a chord with me' but, like other participants, questioned 'how you go about making those calculations' and also doubted whether the economic analysis was capable of taking into account all of the values with which the justice system is concerned:

Sometimes the resolution of those tensions is not going to be in accordance with a strict cost-benefit analysis, because the benefit is a fair trial. And that's hard to quantify. ${ }^{122}$

In sum, then, participants found that the economic analysis of civil procedure was of, at most, limited value. Most viewed its foundations as inadequate and its application as impractical.

\section{Dworkin: Moral Harm and Procedural Rights}

In contrast to the economic cost-benefit analysis advocated by Posner, Dworkin - as explained in Chapter 5 - argues that litigants have a right to a minimum level of procedure, determined by reference to the risk of 'moral harm' involved in an erroneous judicial decision. ${ }^{123}$ Many participants agreed that there is a minimum level of procedure which courts must provide. ${ }^{124}$ In fact, this idea tapped into some participants' deepest beliefs about the legal system:

I think subconsciously that idea [of a minimum level of procedure] does exist. I think there is, amongst practicing lawyers and judges, ... an innate sense of a certain minimum standard which needs to be observed. ${ }^{125}$

There has to be a minimum: the fundamental aim of the process has to be a result that is sound.... If the processes aren't geared towards achieving a sound result

\footnotetext{
120 Judge Richard A Posner, How Judges Think (Harvard University Press 2008).

121 Interview with Participant $\mathrm{H}$.

122 Interview with the Honourable Neville Owen (King's Park, WA, 5 March 2013).

123 See Chapter 5, 71-5.

124 Interview with Justice David Bleby (Adelaide, 16 February 2012); Interview with Justice David Harper (Melbourne, 19 November 2012); Interview with the Honourable Malcolm Lee QC (Fremantle, 6 March 2013); Interview with Chief Justice Wayne Martin (Perth, 6 March 2013); Interview with Justice Peter McClellan (Melbourne, 5 June 2012); Interview with Justice Robert McDougall (Sydney, 6 June 2012); Interview with the Honourable Neville Owen (King's Park, WA, 5 March 2013); Interviews with Participants B, D, F and G. Interview with Justice David Bleby (Adelaide, 16 February 2012).
} 
then there's something wrong. Irrespective of the time and cost, that at least has to be the aim, and then time and cost considerations can operate on that aim. But if you don't have that as your aim I'd have a real issue. ${ }^{126}$

In earlier times anyway (I don't know how things are taught these days) it would have been in every lawyer's knapsack: a creed that ... your client had an entitlement to have an impartial determination by someone who applied themselves to it and did so without conflict. ${ }^{127}$

You appoint judges ... to guard rights. And people have a right to take what they regard as an infringement of their rights [to court] ... This is a fundamental part of our constitutional system. ... So I think ... of these four, that's the theory that's closest to my way of thinking. ${ }^{128}$

Absolutely [litigants are entitled to a certain level of procedure]. I think that's what distinguishes courts from other decision-making bodies. ${ }^{129}$

While not referable to Dworkin's work, the judgment of Austin J in ASIC $v$ Rich ${ }^{130}$ stands as an example of a judge in mega-litigation refusing to relax the standards of justice below a certain level, even in light of efficiency pressures, the overriding objective, and the High Court's judgment in Aon. Austin J said:

It seems to me that general issues about the allocation of judicial resources are not matters to be addressed by the trial judge, whose judicial duty is to hear and determine a case that has properly come before him or her, in accordance with established procedures. Manufacturing special procedures simply to deal with the length of the trial seems to me to raise a real risk of injustice, and so I have not done so. The fundamental principle to be observed by a judge who is required to manage and hear a long case, indeed any case, is to strive to do justice, procedural and substantive, between the parties according to law. It is a principle reflected in the judicial oath, to do right to all manner of people after the laws and usages of the State of New South Wales without fear or favour, affection or ill-will. It is a principle that extends to matters of case management. ${ }^{131}$

Both Austin J's remarks, and those of interview participants, show us that Dworkin's theory accords with some fundamental conceptions about the role of lawyers, of courts, of procedure and of the justice system itself. In Chapter 8 I made similar

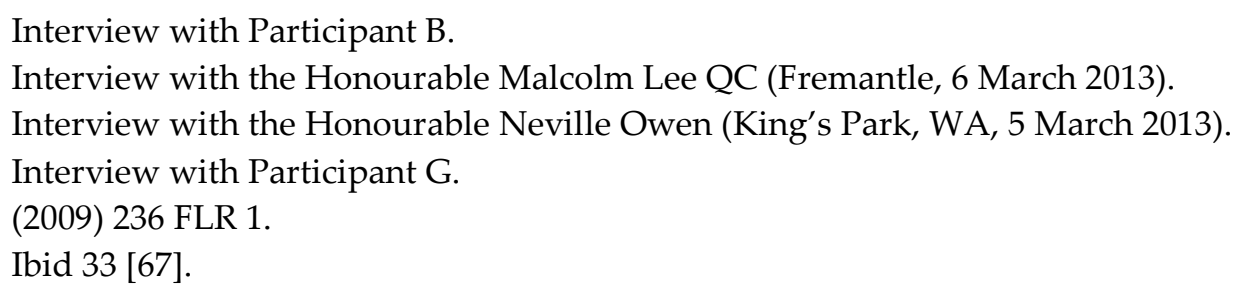


observations about procedural fairness ${ }^{132}$ and, indeed, several participants equated Dworkin's minimum level of procedure with the rules of procedural fairness. ${ }^{133}$ For Austin J in ASIC $v$ Rich, it was those rules that fixed the minimum level of procedure to which the litigants were entitled:

One part of the irreducible core of doing procedural justice according to law is (subject to some limitations, of course) to facilitate the plaintiff's presentation of the case it has chosen to bring to court, and to facilitate the defendant's answering of that case in court. It is not the judge's function to stand in the way of the plaintiff or the defendant in presenting their respective cases. A judge who restricts the presentation of a case on the ground that the case is too long, or too detailed, or too complex, runs the risk that his or her ruling will be tantamount to shutting down that party's case. The same considerations apply to restricting cross-examination to such a degree that significant components of the evidence cannot be addressed by the cross-examiner. ${ }^{134}$

But Dworkin's procedural rights do not entitle litigants to do whatever they want. After all, Dworkin does not claim that there is a right to anything more than a minimum level of procedure. Above the minimum, there is room for compromise. Accordingly, several participants pointed out that it was possible, consistently with the existence of Dworkin-style procedural rights, to limit the procedures available to litigants in order to improve efficiency. ${ }^{135}$ One participant agreed that litigants were entitled to a certain level of procedure, but explained that this did not provide many answers:

The problem is, to do the balancing exercise. In theory, where [Dworkin's theory] might lead you is the position that more or less obtained before we had the case management revolution: that every litigant is entitled to run his or her own case, to the lengths that the litigant considers appropriate ... But we can't afford that, and so there have to be limits imposed. But there must be ... a core protection of fundamental values of procedural fairness. Of course we recognise that procedural fairness is essential to the operation of the judicial system. But that doesn't mean that a party has to have unlimited opportunities to pursue the

\footnotetext{
$132 \quad$ At 145.

133 Interview with Justice David Harper (Melbourne, 19 November 2012); Interview with the Honourable Malcolm Lee QC (Fremantle, 6 March 2013); Interviews with Participants D, F and G.

134 Australian Securities and Investments Commission v Rich (2009) 236 FLR 1, 33 [68].

135 Interview with Justice Peter McClellan (Melbourne, 5 June 2012) (suggesting that the level of procedure required in civil cases might be lower than that required in criminal cases), Interview with Justice Robert McDougall (Sydney, 6 June 2012) ('you can't expect every piece of litigation to get the Rolls Royce treatment').
} 
case. So in a sense it just postpones the hard question that has to be asked in a particular case: how much procedural fairness? ${ }^{136}$

On a similar note, David Bleby observed:

I'm not sure where you would draw the line of the minimum level. ... It's difficult to know where to fix the level, and how to fix the level. ${ }^{137}$

Another note of caution was that Dworkin's theory may not operate well in the 'real world', ${ }^{138}$ in which judges are under pressure to limit the amount spent on what one participant described as 'elaborate decision-making'. ${ }^{139}$ A response to these concerns may be that Dworkin advocates a minimum level of procedure and does not deny that efficiency considerations have a legitimate place in procedural decisionmaking. ${ }^{140}$

In summary, Dworkin's theory resonated with most participants, although there were reservations about its practicality. But the theory only partially answers the question of how a judge should approach a particular procedural decision. A decision to strictly enforce a time limit on filing witness statements, for example, might not fall below the minimum standard Dworkin envisaged. But does that mean that the judge should make the decision? Once again, the judge will have to turn to other sources - rules, principle, or intuition - in order to decide what is appropriate in each case.

\section{Summers: Process Values}

The final theory introduced in Chapter 5 was Summers' idea that procedure, as well as being a means to an end (such as efficiency or an accurate result) could be an end in itself by embodying 'process values'. Many participants found this theory consistent with their own views. ${ }^{141}$ One participant, when asked whether process values were important, replied:

\footnotetext{
136 Interview with Participant G.

137 Interview with Justice David Bleby (Adelaide, 16 February 2012).

138 Interview with the Honourable Ray Finkelstein QC (Melbourne, 21 November 2012).

139 Interview with Participant G.

140 See Ronald Dworkin, A Matter of Principle (Clarendon Press, 1986), 84, and the discussion in Chapter 5 at 73-4.

141 Interview with Justice David Harper (Melbourne, 19 November 2012); Interview with the Honourable Malcolm Lee QC (Fremantle, 6 March 2013); Interview with Chief Justice Wayne Martin (Perth, 6 March 2013); Interview with Justice Peter McClellan (Melbourne, 5 June 2012); Interview with Justice Robert McDougall (Sydney, 6 June 2012); Interviews with Participants B, $\mathrm{F}$ and $\mathrm{G}$.
} 
Oh, absolutely. Of course. I mean, putting it in colloquial terms, people want to get a fair go and they must be seen to get a fair go. And there are certainly many litigants, even though they lose, who say 'I got a fair go, and I got a hearing, and I lost, and I am really disappointed that I lost but I understand.' But also because they've had their day in court. I mean, there are notions in simple terms, colloquial terms, that express these ideas, and that's what courts are meant to do. ${ }^{142}$

Consistently with the emphasis most participants placed on fairness, ${ }^{143}$ fairness was one 'process value' that participants identified. ${ }^{144}$ Other participants said process was capable of embodying the values of dignity, ${ }^{145}$ participation, ${ }^{146}$ humanity, ${ }^{147}$ autonomy, ${ }^{148}$ transparency, ${ }^{149}$ reason $^{150}$ and intelligibility. ${ }^{151}$ Robert McDougall explained how his philosophy of reaching procedural decisions by consent (rather than coercion) wherever possible in mega-litigation could be seen as giving effect to process values:

One of the aims of procedural justice ... is to try and get the parties to come on board and agree that this is the appropriate way, procedurally, to move their dispute forward and to decide it. So you have participation, you have involvement in governance, and you have, I hope, the procedural mechanisms serving the ultimate outcome of a fair trial. ${ }^{152}$

One Federal Court judge reflected on the way in which active case management of complex cases could help the parties (as distinct from their lawyers) become involved in, and understand, the process:

A general counsel of a very very large corporation ... said to me 'I turned up at the first directions hearing in a case in front of you and it was the first time it had ever been explained to me, because I was sitting there hearing someone independent saying "I don't understand that issue ... can you explain how it fits?" "It fits this way your Honour, look at this agreement."'

\footnotetext{
142 Interview with Participant G.

143 Discussed in Chapter 8 at 144-9.

144 Interview with the Honourable Malcolm Lee QC (Fremantle, 6 March 2013); Interview with Chief Justice Wayne Martin (Perth, 6 March 2013); Interview with Participant G.

145 Interview with Justice David Harper (Melbourne, 19 November 2012); Interview with Participant G.

146 Interview with Justice Robert McDougall (Sydney, 6 June 2012).

147 Interview with Participant F.

148 Interview with Participant G.

149 Interview with Chief Justice Wayne Martin (Perth, 6 March 2013).

150 Interview with Participant G.

151 Interviews with Participants B, F and G.

152 Interview with Justice Robert McDougall (Sydney, 6 June 2012).
} 
And then a question arose about discovery ... and there was great debate about the scope. We came down to two or three documents that needed producing. And counsel said to me when the case had finished '...first of all I understood the issues for the first time. Second of all, I was able to go back to my office and say to the people on the ground, 'the judge has worked out that the issue is X, I understand that issue, and we have to produce the following four bits of paper because they will go to show A, B and C relevant to that issue.' And not only did she own it, but the people on the ground within the company owned it because they had someone inside saying 'no, this is actually right, and we understand why it's being done'. The old process was some lawyer within some law firm ... ringing up [the client] and saying 'I want the following documents'. 'We're not giving them to you, why should I produce them?' So [Summers] is right, they have to own the process. ${ }^{153}$

Responses such as these demonstrate, once again, that managing mega-litigation effectively involves understanding human relationships as well as legal principles.

One participant considered the way in which process values might affect attempts to improve the efficiency of court processes:

[Process values explain] why there is a limit to what courts can legitimately do in order to achieve productivity, as distinct from fairness. ... I think there will be a move towards providing opportunities for decisions in a quicker time frame and thus necessarily involving more limited opportunities to put cases, but there's a limit to how far you can take that. It may be that you can offer that opportunity, but you want to be cautious about imposing it. And that's because there is a certain core function that courts have, that involves procedural fairness, it involves values of reasoning, it involves respecting the autonomy and dignity of people, it involves giving them an opportunity to put their case, and courts will not be doing their job if they don't serve those values. ${ }^{154}$

This participant then pointed out that recognising the importance of process values does not obviate the need to reconcile competing objectives; if anything, it only adds another objective into the mix:

Again, it comes back to, perhaps, questions of proportionality, where you've got to measure those values, important as they are, against others, and try and achieve a fair balance ... ${ }^{155}$

\footnotetext{
Interview with Participant E.

Interview with Participant G.

Ibid.
} 
Process values, then, provoked a similar response to Zuckerman's concept of the three dimensions of justice discussed above. While the theory did resonate with many participants, it did not promise to help make particular decisions.

\section{The Role of Theory in Procedural Decision-Making}

In general, participants felt the theories of Zuckerman, Dworkin and Summers embodied some important truths about procedure. In the end, however, participants recognised that the theories left the task of balancing different objectives in the hands of each judge. The theories do not take us much further, then, in our search for a way of reconciling justice and efficiency in mega-litigation.

A further caveat to this discussion is that theory may have only a limited role in judicial decision-making in general. John Gava argues that

to expect a judge to be theoretically pure and consistent when facing real-world problems, with litigants who want an answer to their problem (and not an abstract scholarly treatise) in real-world time, is to totally misunderstand the judicial function and the constraints operating on judges. Judges are not and cannot be theorists. They do not have the time or expertise to be genuine theorists. Indeed, a judge trying to decide cases in strict accord with a particular economic or social theory, or indeed a particular jurisprudential theory, would quickly find out how impractical such a tactic would be. No judge has the time to master theories, as well as the common law, and to apply a theory comprehensively within the time frame allowed by a busy docket. Not only would a judge who attempted to decide cases according to a theoretical position not be a legalist judge, he or she would be attempting the impossible. ${ }^{156}$

The comments of some interview participants reflected this position. One participant said, half-joking, 'Judges don't talk about theory. Maybe we should.'157 Another said:

The trouble is that there is not a great deal of scope for the luxury of philosophical or jurisprudential consideration when you've got a thousand cases in your list. ... So Richard Posner's economic analysis, and Dworkin ... these kind of things are fascinating to discuss but they have very little role to play if you have a thousand cases on the list. ... So you have to operate on instinct. ${ }^{158}$

In the following section I take up this point: the role of 'instinct' - or, as I call it, 'expert intuition' - in reconciling justice and efficiency in mega-litigation.

\footnotetext{
156 John Gava, Sir Owen Dixon: A Strict and Complete Legalist? His Contract Decisions Examined (PhD thesis, University of Adelaide, 2010), 8-9, referring to Posner, above n 120.

157 Interview with the Honourable Michael Black AC QC (Melbourne, 22 November 2012).

158 Interview with Participant A.
} 
In short, theory appears to play a limited role in the making of procedural decisions. ${ }^{159}$ The rapid-fire pace at which procedural decisions must be made makes theoretical reflection something of a luxury. By their nature, theories operate at a fairly high level of generality. Individual procedural decisions, in contrast, are extremely fact-sensitive. I concluded the discussion of procedural theories in Chapter 5 by observing that each of the theories appeared to leave a wide margin for the exercise of discretion for judges making individual decisions. The analysis in this chapter bears out that conclusion. Theories were seen as useful and interesting but ultimately did not provide solutions to the dilemmas thrown up by individual procedural disputes in mega-litigation.

\section{Expert Intuition}

We have seen in this chapter that court rules, appellate authorities, and theoretical approaches can inform procedural decision-making. But I have argued that none of these rules, authorities, or theories can answer individual procedural questions. At most, they can identify the relevant factors, help to provide reasons for decisions, and perhaps narrow the options from which a judge may legitimately choose. But in many procedural disputes, there remains a gap between the guidance that law and theory can provide, and the decision that must be made. ${ }^{160}$ The interview data suggests that, in practice, the gap is filled by each judge's expert intuition.

I have borrowed the term 'expert intuition' from the work of the psychologist Daniel Kahneman. ${ }^{161}$ Kahneman's uses the term to describe the way in which an expert can make a rapid, accurate, apparently miraculous assessment of a complex situation. Expert intuition is at play when an experienced fire-fighter moves away from part of a burning building that collapses seconds later, or when a chess grand master makes a choice that leads to check mate seven moves later. ${ }^{162}$ Kahneman argues that there is nothing miraculous about these decisions. A person who has extensive experience and training in a particular field - an expert - is able to draw on their knowledge of similar situations in order to make an extremely rapid assessment of a new situation. These assessments are intuitive in the sense that they are not based on a conscious

159 For an argument that theory ought to play a greater role in court procedure, see Robert G Bone, 'Making Effective Rules: The Need for Procedure Theory' (2008) 61 Oklahoma Law Review 319.

160 The principle that appellate courts should not usually interfere with a discretionary judgment made on a question of procedure reflects an acknowledgement of this 'gap': see Squire v Rogers (1979) 39 FLR 106, 113-4 (Deane J); Sackville-West v Attorney-General (1910) 128 LT Journ 265.

161 See Daniel Kahneman, Thinking, Fast and Slow (Penguin 2011) Ch 22; Daniel Kahneman and Gary Klein, Conditions for Intuitive Expertise: A Failure to Disagree (2009) 64 American Psychologist 515. 
reasoning process, but on closer examination they are based on a rational, informed analysis. If asked why they moved away from part of a building immediately before it collapsed, the fire-fighter might be able to explain that they perceived visual, aural and temperature cues that their training and experience had taught them to recognise. But at the time of making the decision, the fire-fighter may not consciously have gone through this reasoning process, or even identified the relevant cues as the prompts to move. At the time, the fire-fighter just knew they had to move.

This is not, of course, a psychology thesis and the sense in which I use the term 'expert intuition' is slightly different from that in which Kahneman uses it. Kahneman's concept of expert intuition operates in situations in which there is an external standard by which to measure the correctness of an outcome. We know the fire-fighter made the right decision because part of the building collapsed immediately after the fire-fighter left. We know the grand master made the right decision because she won the game. I am using the term 'expert intuition' in the context of discretionary procedural decision-making. There is no objective standard for determining whether such a decision was correct. Some decisions will be overturned on appeal, but an appeal court will only interfere with a discretionary procedural ruling in exceptional circumstances. ${ }^{163}$ There is a wide margin for the exercise of discretion. Within that margin, there may be several different decisions that are equally correct, or that different persons would consider correct.

Despite this, I suggest that the process by which a judge arrives at a procedural decision resembles that by which the fire-fighter reaches a decision to move from a dangerous part of a fire. When a judge makes a decision based on expert intuition, they are not simply doing what they feel like; they are bringing to bear a lifetime of experience and education in legal practice. Such a decision is not uninformed or arbitrary. So, for example, if a judge in mega-litigation has to decide whether to allow discovery of a certain category of documents, the judge is likely to take into account their experience of discovery as a solicitor and counsel; their understanding of the usual cost and time associated with discovery; the relevance of the documents to the case, based on a nuanced understanding of the issues; and the likelihood, as evidenced by that judge's experience of discovery in hundreds of cases, that this

163 Australian Coal and Shale Employees' Federation v Commonwealth (1953) 94 CLR 621, 627 (Kitto J); Squire v Rogers (1979) 39 FLR 106, 113-4 (Deane J); Sackville-West v Attorney-General (1910) 128 LT Journ 265; Bomanite Pty Ltd v Slatex Corp Aust Pty Ltd (1991) 32 FCR 379, 386-7 (Gummow J), 391 (French J); Queensland v JL Holdings Pty Ltd (1996) 189 CLR 146, 163 (Kirby J), and see the discussion below at 239 . 
category of documents will contain a 'smoking gun'. The judge may not go through a conscious process of working through each of these factors; instead, the judge will be able to make a rapid assessment drawing on decades of expertise. By 'expert intuition' I mean to convey something more than gut feeling.

Several interview participants spoke about the role of expert intuition in procedural decision-making in mega-litigation. Peter McClellan, when asked how he determined whether parties were getting a proper hearing, replied: 'Gotta get a sense. You've got to get a sense of it.' ${ }^{164}$ Justice David Harper spoke about the role of intuition in making procedural decisions when the interests of justice and efficiency came into conflict:

Because of the nature of the job you have to make a decision. And you just do the best you can, and cross your fingers and hope that the best turns out to be, in the end, the correct decision. But you know that you won't always get it right. ... You can't really draw on principles because there's no way that you can weigh two quite different sets of considerations. ... You have to try and compare that which can't be compared. And since that's impossible by definition and impossible in fact, the best you can do is take an educated guess. ${ }^{165}$

One participant said a judge managing complex litigation needs to reach a 'balance between cost and a minimum requirement of fairness'. When asked how this balance could be struck, the participant replied 'Well, one would hope that experience teaches you to do it intuitively. ${ }^{\prime 66}$ Another participant made a very similar observation:

You have to make sure that the case finishes within reasonable parameters but you also have to make sure the parties feel they're getting a proper hearing. So there's a balance... And that comes with effort and experience. ${ }^{167}$

This participant explicitly acknowledged the role of intuition in making procedural decisions:

A huge amount of this is instinct. The idea of doing justice between the parties, of taking into account interests of people who are not parties, of balancing expeditious hearing with facilitating that parties get an appropriate right to be heard, and feel that they've had a right to be heard, balancing bringing a case to court in a quick space of time with the time that is required to give a proper judgment, balancing the proportionality of the amount involved and the subject

\footnotetext{
164 Interview with Justice Peter McClellan (Melbourne, 5 June 2012).

165 Interview with Justice David Harper (Melbourne, 19 November 2012).

166 Interview with Participant D.

167 Interview with Participant A.
} 
matter of the argument, the size of that with the time the court is able to give properly to the determination of that issue, due regard for the cost of doing things proportionally to the benefit that will be obtained - all of those things, which are procedural in nature, largely turn on instinct. One knows when something is right and when it is wrong. ... I was taught that in general terms from an ethical standpoint, if something is not right, you will know just by the fact that your instinct will tell you 'this can't be right'. ${ }^{168}$

For these participants, the resolution of complex procedural disputes involving competing interests and objectives is driven, not by rules or theories, but by expert intuition. The position is captured in the words of one participant, who sketched out a diagram to explain that he saw justice as involving

A sort of dynamic between cost up here, delay down there, access to courts there, money, and ... we look at that point of equilibrium where you get access to justice, affordable justice, not perfect justice. But what is clearly recognised as substantial, accessible justice according to law. ... Somewhere we've got this big sheet of paper with lots of pull points on it. Somewhere in the middle there's an equilibrium. And if it's in the circle which you can recognise as being substantial justice according to law, then that's where you should be. ${ }^{169}$

According to this interview participant, the task of a judge, when making a procedural decision, is to ensure that their decision falls, figuratively, in the circle at the middle of the paper. Exactly where the decision falls, within that circle, is a matter for the judge's expert intuition.

Relying on expert intuition to solve procedural dilemmas does leave judges free to take a leisurely approach to the management of mega-litigation. A judge's expert intuition might tell them to leave no stone unturned; to give the parties every opportunity to present their case as they see fit. As a solution to the problem of inefficiency in mega-litigation, then, expert intuition - like the other solutions offered in this chapter - depends for its efficacy upon the commitment and personality of individual judges.

Another obvious criticism of the use of expert intuition is that it creates the risk of arbitrary, idiosyncratic decision-making. ${ }^{170}$ The American procedural scholar, Robert G Bone, has criticised the approach to procedural decision-making in US courts: 'a pragmatic style of reasoning that relies on an ad hoc and largely intuitive balancing

\footnotetext{
168 Interview with Participant A.

169 Interview with the Honourable Michael Black AC QC (Melbourne, 22 November 2012).

$170 \quad$ See Elliott, above n 28, 316-18.
} 
of "process values"'. ${ }^{171}$ Much the same observation could be made about procedural decision-making in Australian courts. ${ }^{172}$ Bone argues that this reflects the lack of a clear normative direction for procedural law. He contends that under the ad hoc, intuitive balancing approach, 'idiosyncratic personal responses, rather than principles of judicial conduct consistently applied, will govern the outcome of [procedural] disputes'. ${ }^{173}$

One response to this criticism is that, while discretion in procedural decision-making may be wide, it is not unbounded. Judges in mega-litigation do not simply do what they feel; they are guided by rules, authorities, principles and, ultimately, constitutional limitations. ${ }^{174}$ For instance, fairness is a powerful restriction on judicial discretion. ${ }^{175}$ Court rules and case law are available to provide guidance to judges when making procedural decisions. Furthermore, to the extent that procedural decisions are based on intuition, as emphasised above, what is in question is expert intuition. This intuition is informed by a lifetime of experience and scholarship; not by the length of the judge's foot. ${ }^{176}$

In addition, there is arguably no realistic alternative to the ad hoc balancing approach and the ultimate reliance on intuition. ${ }^{177}$ The examination, in this thesis, of the various theoretical, legislative and doctrinal responses to the problem of justice and efficiency in civil procedure revealed that virtually all of these responses leave the individual judge with a wide discretionary margin. Chapters 6 and 7 demonstrated that movements towards providing a normative direction to guide the exercise of that discretion have triggered reactions in different directions. The preJudicature Acts emphasis on rules-for-the-sake-of-rules gave way to the generosity of the justice-on-the-merits era, which in turn led to the rise of efficiency-driven case management. The fact that procedural decision-making is not governed by a consistent normative principle may indicate that judges, scholars and lawmakers have not yet hit upon a satisfactory normative basis for procedural law. I suggest,

\footnotetext{
171 Bone, above n 159, 326. 'Process values' are discussed in Chapter 5.

172 See, eg, Byron $v$ Southern Star Group Pty Ltd (1995) 123 FLR 352, 354 (Kirby P); Chief Justice John Doyle, 'The Machine of Justice - Who is Driving It?' (2007) 28 Adelaide Law Review 7, 19; Michael Legg, Case Management and Complex Civil Litigation (Federation Press 2011), 241-2.

173 Queensland v JL Holdings Pty Ltd (1995) 189 CLR 146, 164 (Kirby J), referring to Judge William W Schwarzer, 'Case Management in the Federal Courts' (1996) 15 Civil Justice Quarterly 141, 142.

174 See Chapter 7 at 98-106 for a discussion of the constitutional influences on procedure.

175 See discussion in Chapter 8 at 144-9.

176 Cf John Selden, Table Talk (1689), 18.

177 For a classic description and defence of the role of intuition in judicial decision-making, see Joseph C Hutcheson, Jr, 'The Judgment Intuitive: The Function of the "Hunch", in Judicial Decision' (1929) 14 Cornell Law Quarterly 274.
} 
though, that the reason lies in the nature of procedural decision-making. Civil procedure is pragmatic. As demonstrated throughout this thesis, it has multiple, sometimes competing, objectives. It involves taking account of not only legal rules, but also resource pressures; practical considerations about the ongoing conduct of the case; and, in the case of mega-litigation, the need to maintain harmonious relationships between judge, lawyers and parties over a period of years. Perhaps there is no normative principle capable of capturing this intensely practical and human task.

The case law on appeals from procedural decisions acknowledges the role played by the personality and intuition of trial court judges. It is well established that an appeal court will not interfere with a discretionary procedural decision except in exceptional circumstances. ${ }^{178}$ While a member of the New South Wales Court of Appeal, Kirby P explained that appellate courts

will show restraint and respect for the primacy of a judicial officer conducting a trial. This is done out of recognition of the extremely large variety of circumstances which have to be taken into account in the conduct of a trial in ensuring that it proceeds to its result fairly and produces orders which dispose of the controversy justly and in accordance with law. Appellate courts also recognise the variety of the personalities and dispositions of those who constitute the judiciary. Some judicial officers are, by personality and disposition, more inclined to intervene in proceedings than others. The appearance of justice and fair procedures does not impose a monochrome uniformity upon judicial conduct such that only one style of conducting proceedings is permitted. ${ }^{179}$

Passages such as this are consistent with the reality this thesis has revealed: there is no such thing as one-size-fits-all civil procedure, particularly in mega-litigation. It may be that the relationship between justice and efficiency in mega-litigation can only be managed by the expert intuition of individual judges, guided - but not bound - by rules, case law and principles.

\section{CONCLUSION}

This chapter has answered the question at the heart of this thesis: how do judges in mega-litigation reconcile the demands of justice and efficiency?

\footnotetext{
$178 \quad$ Australian Coal and Shale Employees' Federation v Commonwealth (1953) 94 CLR 621, 627 (Kitto J); Squire v Rogers (1979) 39 FLR 106, 113-14 (Deane J); Sackville-West v Attorney-General (1910) 128 LT Journ 265; Bomanite Pty Ltd v Slatex Corp Aust Pty Ltd (1991) 32 FCR 379, 386-7 (Gummow J), 391 (French J); Queensland v JL Holdings Pty Ltd (1996) 189 CLR 146, 163 (Kirby J). 
My first two answers to this question involve the mega-litigation judge seeking to give effect to both justice and efficiency by seeking innovative ways of proceeding and by using active case management to ensure a sharp focus on the issues. This provides insights into the role of the mega-litigation judge. In this thesis, the megalitigation judge has emerged as something of a maverick: imaginative, innovative, proactive, seeking to change the system from within. Many of the formal trappings of procedure have been cast off; these judges make their own rules. ${ }^{180}$ Two pillars of the adversarial system - party control, and its counterpart the passive judge - have no place in the management of mega-litigation. But perhaps the role of the megalitigation judge is not as radical as it may seem. The analysis in this chapter shows that, while mega-litigation judges accept that efficiency is imperative, at heart their approach is directed to something that has always been the role of the judge: doing justice in each case. In order to fulfil this role, mega-litigation judges have found it necessary to change the way they run cases, and to reject some long-held principles of civil procedure. But as we saw in Chapters 6 and 7, civil procedure has been in a constant state of change since at least the 1870s. There is nothing novel in courts adapting civil procedure to changing circumstances. In one sense, despite all their creativity and innovation, mega-litigation judges may be doing something deeply traditional: seeking to do justice according to law, following a fair procedure.

What has changed is that in mega-litigation - as in the civil justice system generally judges are now seeking to achieve additional aims, including efficiency for the parties and the public, and justice from the public point of view. Sometimes, these aims will be in harmony: innovation and focus on the issues will serve the various ends of civil procedure. At other times, however, a conflict between these aims will arise. In this chapter I considered several possible ways of resolving this conflict: rules, precedent and theory. I concluded that each of these, while relevant and useful, ultimately throw the question back to the expert intuition of the individual judge.

Having provided some answers to the question posed by this thesis, in the conclusion to the thesis I consider the implications of these findings. 


\section{CHAPTER 11: CONCLUSION}

\section{INTRODUCTION}

In September 2013, almost 18 years after its commencement, following a 404-day trial in the Supreme Court of Western Australia; ${ }^{1}$ a 44-day hearing in the Court of Appeal; ${ }^{2}$ and two and a half hours of procedural hearings in the High Court, ${ }^{3}$ the Bell Group litigation settled. ${ }^{4}$ A spokesman for the appellant banks described the decision to settle as 'a pragmatic decision which will save further time and costs for all the parties involved'; ${ }^{5}$ a statement which would have rung equally true if made 18 years earlier. One media commentator expressed outrage at the scandalous waste of public funds on a dispute that should have been settled at the outset.' 6 These responses to the settlement highlight, once again, the inescapable significance of efficiency considerations - for both the parties and the public - in mega-litigation.

I began this thesis by explaining, in Part I, the problem to which the thesis is addressed. In the introductory chapter, I outlined the key proposition that civil procedure has multiple aims: not only justice between the parties, but justice for the public, and efficiency for both the parties and the public. Chapter 2 expanded on the concepts of justice and efficiency, from the point of view of both the parties and the public. Each of these concepts has been recognised as a goal of civil procedure, and there is the potential for conflict between different aims. Throughout the thesis, we constantly saw judges, commentators and lawmakers reiterating that civil procedure has multiple aims, and that it is no longer sufficient for judges to focus solely on doing justice between the parties.

Chapter 3 developed a definition of the class of litigation which was to be the focus of the remainder of the thesis: mega-litigation. I defined mega-litigation as civil litigation between well-resourced parties involving many complex factual (and, sometimes, legal) issues, with the stakes usually exceeding \$100 million (or very significant non-monetary consequences), the trial often (but not necessarily) taking upwards of 50 days, and often involving multiple parties.

See Bell Group Ltd (in liq) v Westpac Banking Corporation (No 9) (2008) 39 WAR 1.

Westpac Banking Corporation v Bell Group Ltd (in liq) (No 3) (2012) 44 WAR 1.

This consisted of a special leave hearing on 15 March 2013 (Westpac Banking Corporation v Bell

Group Ltd [2013] HCATrans 49), and a directions hearing before French CJ on 24 April 2013

(Westpac Banking Corporation v Bell Group Ltd [2013] HCATrans 85).

4 See John Vaughan and Tony Woodings, 'Bell Case Settlement' (Joint Media Statement, 17 September 2013),

$<$ https://www.icwa.wa.gov.au/icwa/news/icwa_bell_settlement_joint_media_statement.pdf $>$. Ibid.

Richard Gluyas, 'Bell Farce Shows Need For Reform', The Australian, 14 September 2013, 33. 
The interview data established that mega-litigation is an identifiable class of litigation which poses distinct challenges for the justice system. This finding is the result of the most in-depth empirical study of the phenomenon of mega-litigation in Australia to date. There is no single feature of mega-litigation that sets it apart from other litigation; instead, a combination of factors creates mega-litigation. The most significant factor is factual complexity, but this on its own is unlikely to lead to mega-litigation unless augmented by other factors: most likely high stakes and multiple parties. I conceptualised mega-litigation as sitting at one end of a continuum, with very simple cases at the opposite end: there is no dichotomy between mega-litigation and other kinds of litigation. While this means my definition of 'mega-litigation' is necessarily blurry at the edges, it also means the lessons drawn from mega-litigation may be generalisable to other kinds of litigation.

In Chapter 4, which brought Part I of the thesis to a close, I explained that megalitigation places enormous burdens on individual judges and on the court system as a whole. Perhaps most importantly, the burden placed on the court system means that mega-litigation is a problem for the whole community. The court resources monopolised by the parties to mega-litigation are diverted from other litigants within the system and, further, from other objects of government expenditure. I argued that these burdens are so great that the objectives of public justice and public efficiency cannot be ignored in any discussion of mega-litigation.

Part II of the thesis provided an overview of some approaches to the reconciliation of justice and efficiency in civil procedure generally. Chapter 5 examined some exemplar theoretical perspectives on civil procedure: Posner's economic analysis; Zuckerman's balancing of the different dimensions of justice; Dworkin's irreducible minimum standard, and Summers' process values. Chapter 6 traced the history of civil procedure through a series of distinct phases. While justice between the parties was almost the sole purpose of post-Judicature Acts procedure, objectives of efficiency and public justice gained prominence in the second half of the twentieth century. Chapter 7 reviewed the major recent developments in Australian civil procedure. The High Court's change in position over the four cases discussed in that chapter provides yet another illustration of the conundrums presented by the multiple objectives of civil procedure. Overall, Part II reinforced my initial proposition that civil procedure has multiple aims. Different choices can be, and have been, made about the emphasis to place on each of these aims. But all of these potential solutions suffer from the same flaw: they either restate, or leave unanswered, the question of how to reconcile the objectives of justice and efficiency. 
In Chapter 5 I concluded that while these theories provided some useful and contrasting ways of thinking about the problem of justice and efficiency in procedure, none of them offered a complete workable solution. I argued in Chapter 7 that overarching purpose provisions simply list the various objectives of procedure while providing little guidance on their respective priorities, or on the resolution of any conflict between the objectives. ${ }^{7}$ Much the same can be said of the approach currently taken by the High Court. That approach, as expounded in Aon and Expense Reduction, ${ }^{8}$ recognises that civil procedure has multiple objectives and is not just about the interests of the parties. Again, this approach leaves it to courts to work out how to give effect to these objectives.

In Part III of the thesis, I used interview data to focus sharply on the question at the heart of this thesis: how do Australian judges reconcile the demands of justice and efficiency in mega-litigation? Chapter 8 examined the general attitudes that judges bring to mega-litigation. Chief among these was a commitment to highly active involvement in the case. In addition, mega-litigation judges were flexible and innovative in their approach to procedure. Despite these non-traditional tendencies, mega-litigation judges were also characterised by a staunch dedication to timehonoured principles of fairness. Chapter 9 provided a catalogue of the techniques that judges use to manage mega-litigation. These techniques reflected the approaches and attitudes discussed in Chapter 8.

The final substantive chapter, Chapter 10, brought together the key ideas explored in other parts of the thesis. Two of my three major conclusions rest on the idea, foreshadowed in Chapter 2, that justice and efficiency are not mutually exclusive. The first conclusion is that mega-litigation judges use innovation to further the ends of both efficiency and justice. The second is that, by using active case management to focus on the real issues in dispute, mega-litigation judges seek to improve efficiency without compromising justice between the parties. To understand both of these conclusions, it is important to keep in mind a point made in Chapter $2:^{9} \mathrm{I}$ have conceptualised justice between the parties as meaning giving effect to the substantive law and providing a fair hearing. This is not the same as giving the parties exactly what they want. The principle of party control of proceedings has

See page 117-18.

Aon Risk Services Australia Ltd v Australian National University (2009) 239 CLR 175; Expense

Reduction Analysts Group Pty Ltd v Armstrong Strategic Management and Marketing Pty Ltd (2013)

250 CLR 303, discussed in Chapter 7.

At 13-15. 
consistently been rejected since the rise of case management. ${ }^{10}$ By focusing on the real issues and seeking new ways of proceeding, judges may be denying parties the opportunity to present their case as they see fit, but are not necessarily compromising justice between the parties.

Chapter 10 then considered, in light of the 'thick description'11 of the mega-litigation judge in Chapters 8 and 9, how the solutions outlined in Part II can be brought to bear on the problem set up in Part I. This chapter examined the usefulness of theory, rules and High Court authorities in helping judges to reconcile justice and efficiency in mega-litigation. Each of these sources offered some guidance to judges. In particular, many participants thought that the overarching objective provisions of procedural rules and legislation gave judges licence to take an active, interventionist role in case management. The High Court's decision in Aon gave judges the confidence that appellate courts would support such an approach. As discussed in Chapter 7, the dominant trend in Australian civil procedure over the last 20 years has been towards active judicial case management. But Chapter 10 revealed that developments such as overarching purpose rules and the High Court's decision in Aon supported and reflected, rather than precipitated, evolution in case management which had already occurred. This appears to be an area in which the practice of judges in trial courts influences the course of legislation and appellate authority, rather than vice versa.

Ultimately, I argued in Chapter 10 that all of the theories, rules and High Court authorities do no more than point judges in a general direction. They are often useful - particularly when, like the overarching purpose provisions, they give judges freedom to pursue a particular approach. But theory, rules and precedent only go so far. They all leave a substantial gap for the exercise of judicial discretion. It is in this gap that the most difficult questions about the relationship between justice and efficiency arise. In Chapter 10 I explained my finding that this gap is filled by each judge's expert intuition. This is my third major conclusion.

The purpose of this thesis was to discover how judges, in mega-litigation, reconcile the objectives of justice and efficiency. My three major conclusions achieve this aim; an aim that, as stated at the outset, is positive rather than normative. However, it is appropriate to acknowledge, in this final chapter, some practical implications of these conclusions. The next section of this chapter discusses the practical

See discussion in Chapters 6 and 7.

Clifford Geertz, 'Thick Description: Toward an Interpretive Theory of Culture' in Clifford Geertz (ed), The Interpretation of Cultures (Basic Books, 1973) 3. 
consequences for court administration, judicial education, judicial appointment, and law reform that flow from my conclusions. I conclude the chapter - and the thesis itself - by suggesting areas for further study and offering some final reflections.

\section{PRACTICAL CONSEQUENCES OF FINDINGS}

A single theme unites my conclusions: the management of mega-litigation is heavily dependent on the skill, experience, personality and commitment of the individual judge. A corollary of this point is that some judges may not be suited to managing mega-litigation. ${ }^{12}$ Some judges may not be willing or able to engage in highly active case management, to help the parties isolate the key issues, or to craft creative, flexible solutions to procedural challenges. There are judges who do not have extensive experience in complex commercial litigation to inform their expert intuition. There is a risk that, if a mega-litigation matter falls into the hands of such a judge, the matter may become bogged down in inefficiency.

This risk was considered in Chapter 9 of this thesis, in the context of random allocation of cases under a docket system. ${ }^{13}$ A docket system, which involves one judge managing a case from start to finish, emerged as a key to the effective management of mega-litigation. A criticism of the docket system was the possibility that a case could be allocated to a judge who was not proactive in managing the case. One systemic solution to this problem is to ensure that mega-litigation matters are allocated to judges who have been assessed (by the head of jurisdiction, in consultation with the judges themselves) to have the characteristics necessary to manage mega-litigation effectively. Several jurisdictions have a pool of judges who are allocated to manage complex cases. ${ }^{14}$ It is often possible to identify a matter as mega-litigation at an early stage. Allocating such cases to a suitable judge as early as

See, eg, Chief Justice James Allsop, 'Judicial Case Management and the Problem of Costs' (Speech at the Lord Dyson lecture on 'The Jackson Reforms to Civil Justice in the UK', Sydney, 9 September 2014), 15-16 (explaining that case management can be counterproductive in the hands of judges who do not embrace its philosophy).

13 At $160-1$.

14 Examples include the Federal Court's corporations list (see Federal Court of Australia, Administrative Notice NSW 2 - Corporations Matters, 15 May 2014; Federal Court of Australia, Administrative Notices QLD 1 - Corporations Matters, 1 August 2011; Federal Court of Australia, Administrative Notice WA 1 - Corporations Matters, 25 September 2009), the Supreme Court of New South Wales' commercial list (see Supreme Court of New South Wales, Practice Note No SC Eq 3 - Supreme Court Equity Division - Commercial List and Technology and Construction List, 12 October 2008), the Supreme Court of South Australia's special classification list (see Supreme Court Civil Supplementary Rules 2014 (SA) ch 6) and the Supreme Court of Victoria's Commercial Court (see Supreme Court of Victoria, Practice Note No 10 of 2011 - Commercial Court). 
possible can ensure that each case is managed as effectively as possible. In this area, heads of jurisdiction may need to take responsibility for identifying and allocating mega-litigation matters appropriately.

Judicial education may be helpful for judges who are not naturally suited to managing mega-litigation. Several interview participants said education could improve judges' ability to manage mega-litigation. ${ }^{15}$ One participant identified education of judges - and lawyers - as the key to managing mega-litigation more effectively in the future. ${ }^{16}$ As noted in Chapter $8,{ }^{17}$ some participants reported receiving very little or no formal preparation for mega-litigation. Until recently, there has certainly been a shortage, in Australia, of written guidance on managing mega-litigation. ${ }^{18}$ In recent times there have been some efforts, on the part of judges ${ }^{19}$ and commentators, ${ }^{20}$ to remedy this situation.

Some participants had reservations about the efficacy of judicial education. Ray Finkelstein said case management could be taught, 'up to a point' but was ultimately 'very much personality driven' and that generally speaking, judges tended to resist efforts to educate them. ${ }^{21}$ Another participant said that, while guidelines or education could 'state at a general level what is required' in case management, this would not necessarily prepare a judge for

what you actually do in the circumstances of a particular case, what precise rules you make and how you deal with the shenanigans that parties and lawyers get up to..$^{22}$

In any event, education cannot act as a substitute for the attributes of the megalitigation judge identified in Chapter 8 . The mega-litigation judge recognises that

15 Interview with Chief Justice Wayne Martin (Perth, 6 March 2013); Interviews with Participants

$\mathrm{E}$ and $\mathrm{F}$.

16 Interview with Participant E.

17 At 140.

18 Such guides do exist in other jurisdictions: see, eg, Judiciary of England and Wales, Report and Recommendations of the Commercial Court Long Trials Working Party (December 2007); Federal Judicial Center, Manual for Complex Litigation, Fourth (2004).

19 See, eg, Justice Neville Owen, 'Surpassing Sisyphus - Idle Musings on Surviving Long Trials' (Paper presented at Supreme Court of Victoria Judges' Conference, Mornington Peninsula, 5 November 2009); Acting Justice of Appeal Ronald Sackville, ‘Mega-Lit: Tangible Consequences Flow From Complex Case Management' (2010) Law Society Journal 47.

20 See Michael Legg, Case Management and Complex Civil Litigation (Federation Press, 2011).

21 'None of them want to be told what to do. So even going to judges' school or having some teacher teach them, I think there's a great deal of resentment. They don't like it': Interview with the Honourable Ray Finkelstein QC (Melbourne, 21 November 2012). Interview with Participant G. 
each case is different, that court rules do not set out rigid procedures that must be used in every case, and that the judge must mould procedure to the needs of the case. The interaction between education, flexibility and creativity in mega-litigation is explained in the introduction to the US Federal Judicial Center's Manual for Complex Litigation, Fourth:

In offering an array of litigation management techniques and procedures, the Manual does not recommend that every complex litigation necessarily employ any such procedures or follow a standard pattern. Choices will depend on the needs of the litigation and many other considerations. ...

Much complex litigation ... will take the judge and counsel into sparsely charted terrain with little guidance on how to respond to pressing needs for effective management. Practices and principles that served in the past may not be adequate, their adaptation may be difficult and controversial, and novel and innovative ways may have to be found. While this Manual for Complex Litigation, Fourth should be helpful within the limits of its mission, it should be viewed as open-ended, and judges are encouraged to be innovative and creative to meet the needs of their cases ...23

The value of judicial education, then, lies in making judges aware of the range of techniques at their disposal, and the promulgation of a general approach to managing mega-litigation; not in the prescription of 'one size fits all' templates for procedure in mega-litigation. Further, education cannot replace the innate characteristics described in Chapter 8; nor can it supply the expert intuition identified in Chapter 10 as so important to the resolution of conflicts between efficiency and justice.

A further practical implication of my findings is that judicial recruitment has a large bearing on the efficient management of mega-litigation. In Chapter 8 I explained the ways in which judges' experience as lawyers affected their approach to managing mega-litigation. ${ }^{24}$ Interview participants reported that their experience helped them to understand the motivations of the lawyers and parties in mega-litigation; and armed them with the skills needed to absorb large amounts of material and make complicated procedural decisions rapidly. This suggests that, in those jurisdictions in which mega-litigation is prevalent, priority should be given to appointing judges with extensive experience in complex litigation. Recruiting top commercial lawyers to the bench is easier said than done; such a lawyer may be reluctant to exchange their practice for the comparatively austere life of a judge. But it is by no means

\footnotetext{
23 Federal Judicial Center, above n 18, 2-3.

24 At $150-5$.
} 
impossible to attract such lawyers to the bench; the participants in this project alone provide ample examples of individuals who left commercial practice to become judges. A further objection to the suggestion that priority should be given to those with experience in complex litigation - likely to be leading commercial barristers may be that this tends to reduce both the size and the diversity of the pool of judges available for judicial appointment. ${ }^{25}$ However, this need not be the case. Some of the people who are best suited to manage mega-litigation may be found among an often overlooked source of judicial candidates: commercial solicitors. Some solicitors in commercial litigation firms have enormous experience in complex commercial litigation. Participants in the interviews for this thesis spoke of the value of their experience as solicitors as well as barristers in equipping them with understanding of the motivations of the parties to mega-litigation.

My conclusions may have implications for law reform in the area of procedure. As reported in Chapter $8,{ }^{26}$ several participants said they had abandoned court rules in mega-litigation. Others reported that the existing rules were perfectly adequate to meet the needs of mega-litigation. One participant said:

We have all the weapons we need in the existing rules. There is no need for further reform. Dealing with mega-litigation depends on how judges are able to use their case management powers. ${ }^{27}$

The reaction of a law reformer to my conclusions might be that, if so much depends on the skills, personality and intuition of the individual judge, there is little point wasting time on devising improvements to procedural rules and legislation that will make mega-litigation more efficient. This is not so. On the contrary, it is in megalitigation that procedural innovations are most likely to be welcomed. This is reflected in participants' responses to 'overarching purpose' rules, which were overwhelmingly seen as an important and useful tool for judges. ${ }^{28}$ As explained in Chapter $8,^{29}$ mega-litigation judges embrace innovation and are likely to be early adopters of any developments in procedural rules. Chapter 9 contains many

25 Evans and Williams, for example, argue that traditional approaches to judicial selection focus on advocates while ignoring excellent candidates from other backgrounds, such as solicitors, academics and government lawyers: Simon Evans and John Williams, 'Appointing Australian Judges: A New Model' (Paper presented at the Judicial Conference of Australia Colloquium, Canberra, 7-9 October 2006). See also Baroness Usha Prashar, 'Speech at the Annual ILEX Luncheon' (Clothworkers' Hall, London, 17 May 2006).

$26 \quad$ At 143.

27 Interview with Participant $\mathrm{H}$.

28 See Chapter 10 at 213-15.

29 At $139-41$. 
examples of mega-litigation judges pushing the boundaries of existing procedural techniques in areas such as the use of technology, the management of discovery and expert evidence, the use of referees and the trial of separate issues. My conclusions do not mean that there is no point in continual improvement of court procedure. They do mean, however, that rules can only go so far towards achieving efficiency in mega-litigation. There comes a point at which there is simply no substitute for the skill and expert intuition of the individual judge.

\section{CONCLUSION}

This thesis set out to discover how judges, in mega-litigation, reconcile the aims of justice and efficiency. Having achieved this aim, several areas for further study present themselves. This thesis examines mega-litigation from a judicial perspective. As foreshadowed in the introduction to this thesis, ${ }^{30}$ a similar study from the perspective of lawyers would enrich - and perhaps challenge - the understanding of mega-litigation presented in this thesis. Would lawyers agree that mega-litigation is best managed by transferring control from the parties to the judge? Would they be troubled by the role played by the judge's expert intuition?

This thesis can also provide the basis for normative theoretical and doctrinal analysis of the role of the judge in mega-litigation. Now that we know how judges in fact accommodate the objectives of justice and efficiency in mega-litigation, we can go further and evaluate the merits of the answers offered in this thesis. Chapter 10 introduced some of the critiques that may be made of the role of the judge in megalitigation. These included the departure from the traditionally passive role of the judge, and the risk that reliance on the individual characteristics of the judge will lead to arbitrary, idiosyncratic decision-making. While I offered some preliminary responses to these critiques, there is much potential to explore these arguments in greater depth.

This thesis has touched on the limits placed on judicial innovation by Chapter III of the Constitution. I have suggestedthat the majority of measures taken by judges in mega-litigation are likely to be constitutional. ${ }^{31}$ Even in the midst of their quest for efficiency, mega-litigation judges tend to be preoccupied with fairness. ${ }^{32}$ The preservation of procedural fairness lies at the heart of the constitutional 'due process' principle. $^{33}$ The approach taken by mega-litigation judges - involving active

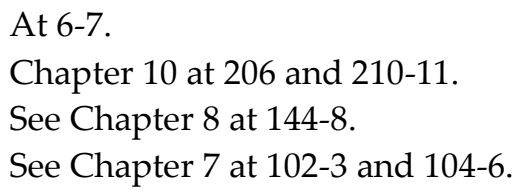


case management, innovative procedures and flexible application of rules - does not, in itself, infringe Chapter III. However, constitutional questions may arise around some particular creative, non-traditional processes used in mega-litigation. Further studies could consider, in detail, the constitutionality of individual procedures.

As I have pointed out in this chapter, my conclusions have practical implications. If those responsible for the administration of justice - such as Attorneys-General, government departments and Chief Justices - believe that courts ought to deal with mega-litigation in the way described in Part III of this thesis, then close attention needs to be paid to judicial appointments and education. But ultimately, there is no guarantee that every case of mega-litigation will be handled by an active, flexible, creative and fair judge of the kind described in Chapter 9. There remains the risk that, in the wrong hands, mega-litigation will become a massive burden on an individual judge, on the resources of the parties, on other users of the justice system, and on taxpayers. Like any task entrusted to human hands, the management of mega-litigation is vulnerable to human frailty, but is also capable of being fortified by human creativity and good sense. 


\section{APPENdix A: Qualitative Research Methodology}

\section{INTRODUCTION}

This thesis relies, in part, on qualitative interviews with 16 judges who have been involved in mega-litigation. The decision to incorporate qualitative research in this project was driven by a belief that available documents - such as judgments and speeches - did not fully capture the complexity of the task of reconciling justice and efficiency in mega-litigation. This is, in part, because this task tends to be one which judges deal with in the course of deciding substantive issues of law or particular procedural disputes. While engaged in such tasks, it is understandably relatively rare for judges to pause and reflect, explicitly, on the precise relationship between the different aims of civil procedure. I wanted to ask judges about the deeper philosophies underlying their approach to managing mega-litigation. My methodology is based on an ontological assumption that the role of a mega-litigation judge depends heavily on the subjective understanding of the people who hold that role. ${ }^{1}$

This appendix sets out the methodology used to conduct the interviews and analyse the data.

\section{SELECTION OF INTERVIEW PARTICIPANTS}

Potential interview participants were selected from among three groups. The first was those judges who had presided over trials of mega-litigation. The second was those who had managed mega-litigation in its pre-trial stages. This group included judges who had presided over mega-litigation that settled prior to, or during trial; and judges who regularly managed commercial litigation lists. The third group was heads of jurisdictions in which mega-litigation had taken place. I believed that members of this group would be able to provide insights into the effect of megalitigation on the work of the court as a whole.

These groupings proved to be a useful basis for selecting participants. Once participants were selected, however, it became unhelpful to maintain divisions between the groups, because most participants fitted into more than one group. For instance, only one participant was a head of jurisdiction who had not presided over mega-litigation, and only one participant fell within the second, but not the first,

This ontological assumption is similar to that adopted by Gabrielle Appleby in her study of the role of the Solicitor-General in Australia: The Constitutional Role of the Solicitor-General: An Historical, Legal and Lived Portrait (PhD thesis, University of Adelaide, 2012), 19. 
group (that is, the participant had case-managed mega-litigation prior to trial but had not presided over a mega-litigation trial). Therefore, the distinction between the groups was largely abandoned at the stage of interview design and was not carried through into the analysis of the data. There is one exception to this position: heads of jurisdiction were asked about the effect of mega-litigation on the overall work of the court.

Two strategies were used to identify potential participants. The first was to peruse published judgments and media reports on mega-litigation. The second was to approach judges and lawyers in various Australian jurisdictions to ask them to suggest potential participants who might meet the criteria; a variation on 'snowball sampling'.2

The aim of my study was not to obtain a statistically representative data set from which generalizations could be drawn with confidence; instead it was to develop deep insights into the world of the mega-litigation judge. Typically, qualitative research results in findings which are

representative in the sense of capturing the range or variation in a phenomenon, but not in the sense of allowing the estimation of the distribution of the phenomenon in the population as a whole. ${ }^{3}$

Accordingly, I used 'purposeful's or 'criterion-based' ${ }^{5}$ sampling in order to facilitate 'detailed exploration and understanding of the central themes and puzzles' ${ }^{6}$ which I wished to study. Michael Patton explains that:

The logic and power of purposeful sampling lie in selecting information-rich cases for study in depth. Information-rich cases are those from which one can learn a great deal about issues of central importance to the purpose of the inquiry ...

2 See Jane Ritchie, Jane Lewis and Gillian Elam, 'Designing and Selecting Samples' in Jane Ritchie and Jane Lewis (eds), Qualitative Research Practice (Sage Publications, 2003) 77, 94. In conventional snowball sampling, suggestions are requested after a participant has been interviewed. In my study, suggestions were requested before the interview and, sometimes, from people who did not fall within the groups of potential participants.

3 Lisa Webley, 'Qualitative Approaches to Empirical Legal Research' in Peter Cane and Herbert M Kritzer (eds), The Oxford Handbook of Empirical Legal Research (Oxford University Press, 2010) 926, 934.

$4 \quad$ Michael Quinn Patton, Qualitative Research and Evaluation Methods (Sage Publications, 3rd ed, 2002), 230.

$5 \quad$ Ibid 238; Ritchie, Lewis and Elam, above n 2, 78.

$6 \quad$ Ritchie, Lewis and Elam, above n 2, 78. 
Studying information-rich cases yields insights and in-depth understanding rather than empirical generalizations. ${ }^{7}$

By selecting participants based on their experiences with mega-litigation, I ensured that I was working with information-rich cases which would yield the data of central importance to my inquiry.

I am confident that the sample size $(n=16)$ was appropriate for this project. As explained above, the rigour of the study did not depend on a sample size which would facilitate statistically representative results; it depended on the richness of the cases selected. Towards the end of the interviews, I found that I had reached a level of 'saturation'; that is, new interviews were no longer yielding significant new insights. Finally, the pool of potential participants was small. I believe I interviewed the majority of living Australian judges within the first two of the three groups targeted (that is, judges who have presided over mega-litigation).

In many respects, the participants were not a diverse group. The selection criteria dictated that all participants were current, or retired, Australian judges. This meant that the education, background and socio-economic status of participants were fairly heterogeneous. Only two participants were women; a reflection of the low number of women in the pool of potential participants. Participants included seven Federal Court and nine Supreme Court judges. The Supreme Court judges were drawn from the Supreme Courts of South Australia, New South Wales, Victoria and Western Australia.

\section{RECRUITMENT OF INTERVIEW PARTICIPANTS}

Participants' contact details were obtained using publicly available sources. Those participants who were current judges were contacted through their chambers. Retired judges generally maintained a public presence, as practising lawyers or through Universities.

Participants were contacted either by email or letter. They were provided with an Information Sheet containing information on the research project and the interviews; a consent form; and contact details to use if they wished to make a complaint about the project. 19 potential participants were approached. Of these, 17 agreed to participate. It was not possible to arrange a mutually convenient time to interview one of the potential participants, leaving a total of 16 participants.

Patton, above n 4, 230 (emphasis in original). 


\section{DEVELOPMENT OF INTERVIEW TOPICS}

The interviews were semi-structured. A number of predetermined topics were covered in each interview, and certain key questions were put to most participants, but there was no standardized order of questions, nor was the wording of particular questions determined in advance. The aim was to create a conversational, openended yet focussed interview; one which combined 'structure with flexibility'. ${ }^{8}$ The semi-structured format allowed for individual topics to be explored in depth, either because the participant had particular experiences or perspectives relevant to that topic, or because it arose in the course of the interview. It also allowed for links between different topics to be explored freely, without adhering to a rigid template of questions.

Developing the interview topics was an iterative process. Initially, I prepared a list of topics and possible questions arising from a literature review on theories of civil procedure, ${ }^{9}$ and a reading of some judgments and literature on mega-litigation. I discussed this list with my supervisors, and with two of my colleagues who had conducted qualitative legal research, and revised the list in light of those conversations. As I began to conduct interviews, I gained a greater understanding of the kind of insights that these interviews could provide. At the same time, I began to analyse the interview data and continued to draft the early chapters of my thesis. This shifted my ideas of how the qualitative research could contribute to the project. Accordingly, I revised the list of topics continually. This practice of constant revision has the disadvantage of creating some inconsistency between the earlier and later interviews. This disadvantage is outweighed by the improved focus and depth that I was able to achieve in later interviews. Further, most of the changes to the interview topics consisted of abandoning less relevant topics and refining the central topics; therefore, the core of the interviews remained the same throughout.

\section{INTERVIEW PROCEDURE}

All interviews took place face-to-face, either at the participant's workplace or at a public venue such as a quiet café. Interviews took between 40 minutes and one and a half hours.

Prior to the interview, participants were provided with some written information on the interview process. As noted above, at the point of being invited to take part, participants were provided with an Information Sheet outlining the objectives of my

Robin Legard, Jill Keegan and Kit Ward, 'In-depth Interviews' in Jane Ritchie and Jane Lewis (eds), Qualitative Research Practice (Sage Publications, 2003) 138, 141.

$9 \quad$ An early draft of Chapter 5 of this thesis. 
research and the format of the interviews. In the week prior to the interview, participants were given an indicative dot-point list of the general topics to be covered. An example of this document (the content varied slightly between participants) is provided as Appendix B to this thesis. In developing this list, I endeavoured to provide enough detail to give the participant a clear idea of what would be discussed. On the other hand, the list was worded in terms of general topics rather than specific questions, in an effort to maintain the spontaneity of answers given during the interview. Providing the outline of topics in advance proved to be an effective technique. By the time of the interview, many participants had made the effort to think of specific examples of mega-litigation they had been involved in, to reflect on my broader research questions, and even to discuss these matters with their colleagues and collect relevant documents.

The document containing the indicative list of interview topics also contained short summaries of the four theoretical perspectives on procedural law explored in Chapter 5 of this thesis. These summaries were intended to give participants time to become familiar with the basic theories, so that they could be asked to respond on the theories during the interviews. The results of this exercise, together with some reflections on the technique used, appear in Chapter 10 of this thesis.

I conducted background research on each participant prior to the interview. I ensured that I was familiar with the participant's professional biography, particularly their areas of practice prior to judicial appointment, and the date of their appointment. I familiarised myself with specific cases of mega-litigation with which the participant had been involved, as well as with any of the participant's publications or speeches on topics such as complex litigation or civil procedure. This preparation enabled me to prioritise certain topics, and formulate specific questions based on the participant's experiences or publicly expressed views.

Before the interview began, participants were asked to sign a consent form. The consent form offered participants the choice of partial, complete or no anonymity. The form also asked participants whether they consented to the interview being recorded electronically. With one exception, participants did consent to recording.

It is in the nature of semi-structured interviews that every interview is different. Further, like the development of topics discussed above, the conduct of the interviews was an iterative process. As I gained experience as an interviewer, and clarified my ideas about the place of the interviews in the overall project, the 
structure of the interviews changed. Subject to those caveats, it is possible to provide an outline of the structure of a typical interview.

Each interview began with a key question: what is 'mega-litigation'? This question was important, not only because it orientated the discussion that followed, but because it was one of the research questions I was investigating. I read out Sackville J's description of mega-litigation in the $C 7$ case, ${ }^{10}$ and asked participants to respond to that description. Did they think it was accurate? Useful? Did they have anything to add? This stage of the interview was often a convenient place to ask another key question: is mega-litigation qualitatively different from other types of litigation?

Participants would then be asked to identify mega-litigation cases in which they had been involved, both before and after being appointed to the bench. Having done background research, I would already have a view about the main cases of megalitigation in which the participant had been involved, but it was important to see if the participant would, themselves, identify a matter as mega-litigation. In addition, many participants had experience in mega-litigation beyond that of which I was aware. At this stage, participants sometimes talked about their experiences in detail, raising many of the issues I wished to cover in the interviews. The semi-structured nature of the interviews allowed me to pursue these issues as they were raised. At this stage of the interview, participants were generally asked about the causes of mega-litigation, both generally and in the specific cases they had been involved in.

Next, participants would be asked some open-ended questions about their experience of procedure in mega-litigation - for example, 'what procedural techniques did you use?' or 'what were the challenges of this litigation?' In this section of the interview, participants might also be asked about specific cases they had been involved in, or views they had publicly expressed. The aim was to draw out both specific techniques and general approaches, with examples and reflection. Many of the most significant and unexpected insights in the project emerged from these discussions. In some of the early interviews, participants were explicitly asked about their attitude to justice and efficiency in mega-litigation in a separate section of the interview. However, as the interview process was refined, it became more natural to discuss issues of justice and efficiency in the course of this general discussion about participants' experience of mega-litigation. This helped to make the link between participants' experiences and techniques, and their underlying attitudes and philosophies. 
A key topic to be covered in each interview was the influence of court rules and High Court authorities on case management. Often, the participant raised these topics spontaneously in the course of discussing their experience of procedure in mega-litigation. If this did not happen, participants were asked how overarching purpose provisions and High Court authorities affected their approach. ${ }^{11}$

The part of the interview dealing with participants' experiences of mega-litigation was concluded by asking if the participants had any suggestions for reforms to the way in which mega-litigation was dealt with.

In the final part of the interview, participants were asked to respond to the short summaries of theoretical perspectives on procedural law which had been provided in advance. They were asked whether these theories had any resonance with their own experience of procedure in mega-litigation.

\section{DATA ANALYSIS}

As noted above, all but one of the interviews was electronically recorded. Extensive contemporaneous notes of the remaining interview were taken. As soon as possible after each interview, I typed a verbatim transcript from the recording. While I considered using an external transcription service, the confidentiality of the interviews, as well as resourcing issues, made this an inappropriate option. Further, I found that the process of typing the notes made me very familiar with the data and gave me the opportunity to self-critique my interview technique.

I then coded the interviews using NVivo software. 'Codes' are 'tags or labels for assigning units of meaning to the descriptive or inferential information compiled during a study. ${ }^{\prime 2}$ Coding is used to dissect and organise raw data and to identify emerging patterns and themes. Before the interviews began, I had developed an index of codes based on my literature review and planned interview questions. When I began to code the interview transcripts, I found many of the codes in this index redundant, and that much of the interview data called for new codes which I had not considered before. Accordingly, I constantly revised the codes throughout the project, and regularly re-coded earlier transcripts to ensure that the data was

11 See the discussion of overarching purpose provisions and High Court authorities in Chapter 7, and participants' responses in Chapter 10.

12 Matthew B Miles and A Michael Huberman, Qualitative Data Analysis (Sage Publications, $2^{\text {nd }}$ ed, 1994), 56. 
placed within the current coding framework. Miles and Huberman emphasise that revising codes is an inevitable part of qualitative research. ${ }^{13}$ They explain that

the field site emits a continuous stream of leads, mysteries, themes, and contradictions that need to be pursued and that will never fit perfectly into a precoded conceptual frame... ${ }^{14}$

I found this to be an accurate description of my experience of coding interviews. Equally resonant is Miles and Huberman's observation that

coding is a way of forcing you to understand what is still unclear, by putting names on incidents and events, trying to cluster them, communicating with others around some commonly held ideas, and trying out enveloping concepts against another wave of observations and conversations. ${ }^{15}$

In other words, coding is not merely a means of organising data for easy retrieval; it is a crucial part of the analysis of the data, and can drive the direction of the project.

The coding process enabled me to see the themes that emerged from the data. I used these themes to structure the chapters of my thesis that relied on the interview data. ${ }^{16}$ When writing these chapters, I used a large number of direct quotes from the interviews because it was important, given my ontological assumption that the role of the mega-litigation judge is influenced by each person's perspective on the role, to retain the participants' voice.

\section{PARTICIPANT REVIEW AND ANONYMITY}

Before the thesis was finalised, each participant was provided with a copy of all quotes, opinions and information which were to be attributed to them in the thesis. In accordance with my ethics approval, participants were given the option of withdrawing this material or requesting that it be made anonymous. Very few participants withdrew any substantive material. Some requested that the grammar or syntax of quotes be changed, and I have accommodated those requests.

Where participants requested anonymity, every effort has been made to honour that request. Such participants have been allocated a random identifying letter (eg 'Participant $C^{\prime}$ ). Where necessary in order to provide context for their opinions, they are described as, for example, 'a Federal Court judge' or 'a judge who case-managed several mega-litigation matters'. I have attempted to omit any details from which

Ibid 61-2.

Ibid 62 .

Ibid.

Chapters 3, 8, 9 and 10. 
the identity of the participant could be ascertained. However, due to the small number of potential participants and the nature of the selection criteria, in some cases the identity of the participant may nonetheless be apparent. This danger was acknowledged in the consent form.

\section{LIMITATIONS OF STUDY}

Some limitations on the study must be acknowledged. Participants were, to a degree, self-selecting. People who agreed to be part of a study on justice and efficiency in mega-litigation might tend to be those who already held strong views on these issues. It is possible that the highly active case management style, and the concern for efficiency demonstrated by the overwhelming majority of participants may not be universal. Different views may be held by those judges who declined to be interviewed.

Limits on time and resources restricted the number of interviews that could be conducted interstate. Despite this, as explained earlier the sample size is appropriate for this study, and participants include representatives of five different jurisdictions (Commonwealth, New South Wales, South Australia, Victoria and Western Australia).

The reliability of the study depends, of course, on the degree to which participants were willing to share their experiences and opinions frankly and openly. In general, participants appeared very frank, often disclosing quite sensitive material including reflections on the difficulties of their role and doubts about some of their decisions. This frankness did have its limits. On occasion, participants were reluctant to speak about specific individuals (such as lawyers and other judges) and kept their remarks at a general level.

While it is important to bear these limitations in mind, the qualitative research design was sufficiently rigorous to ensure that the outcomes are generally reliable. The interviews became a central component of the thesis, not only providing data that helped to answer the research questions, but also shaping the way in which I conceptualised those questions. 


\section{APPENDIX B: EXAMPLE LIST OF TOPICS}

Note: this is a typical example of the outline of interview topics that was provided to participants several days before the interview.

\section{Indicative List of Interview Topics for 'Justice and Efficiency in Civil Procedure: A Judicial Perspective'}

The interview will be semi-structured: there will not be a rigid list of questions, but the general topics set out in this document will be covered, time permitting.

\section{Experience of mega-litigation}

This topic will cover the participant's views on, and experiences of, mega-litigation, including:

- The meaning of 'mega-litigation', and how it differs (if at all) from other litigation.

- The participant's involvement (if any) in mega-litigation as a lawyer.

- The participant's involvement in mega-litigation as a judge, including:

○ The factors that made this matter 'mega-litigation';

○ The challenges the litigation presented for the judge;

○ The techniques used to manage the litigation;

- The way the rules and principles of civil procedure operated in this context;

$\circ$ Whether the aim of doing justice in the individual case ever conflicted with other aims, such as efficiency.

\section{Reform of procedural law in mega-litigation}

Participants will be asked to comment on ways in which procedural law might become better adapted to the mega-litigation context.

\section{Theoretical perspectives on procedural law}

In this section of the interview, participants will be asked to respond to four leading academic theories on the aims of procedural law. Brief summaries of these four theories are provided on pages 2-3 of this document. 


\section{Theoretical perspectives on procedural law}

On the following two pages are brief summaries of four leading theories on the aims of procedural law. As part of my research, I wish to investigate the extent to which these theories are relevant to civil procedure in Australia. Interview participants will be asked to respond to these four theories.

\section{Three dimensions of justice}

Adrian AS Zuckerman:

'All systems of procedure exist to do justice. ... [J] ustice has three dimensions by which it is measured.' ${ }^{1}$ These are rectitude (or accuracy) of decision; time; and cost (for both the parties and the system). These three dimensions 'are not entirely complementary' and 'at times they pull in different directions and call for compromises. Compromise, therefore, is an inescapable feature of any system of justice. ${ }^{2}$ Procedural law should aim to achieve the optimal mix of these three dimensions of justice.

\section{Economic analysis}

Richard A Posner:

'The objective of a procedural system, viewed economically, is to minimize the sum of two types of cost. The first is the costs of erroneous judicial decisions. Suppose the expected cost of a particular type of accident is $\$ 100$ and the cost to the potential injurer of avoiding it is $\$ 90$ (the cost of avoidance by the victim, we will assume, is greater than $\$ 100$ ). If the potential injurer is subject to either a negligence or a strict liability standard, he will avoid the accident - assuming the standard is administered accurately. But suppose that in 15 percent of the cases in which an accident occurs, the injurer can expect to avoid liability because of erroneous factual determinations by the procedural system. Then the expected cost of the accident to him will fall to $\$ 85$, and since this is less than the cost of avoidance to him (\$90), the accident will not be prevented. The result will be a net social loss of $\$ 10-$ or will it?

We must not ignore the cost of operating the procedural system. Suppose that to reduce the rate of erroneous failures to impose liability from 15 percent to below 10 percent would require an additional investment in procedure of $\$ 20$ per accident. Then we should tolerate the 15 percent probability of error, because the cost of error $(\$ 10)$ is less than the cost necessary to eliminate it $(\$ 20) .^{3}$

\footnotetext{
${ }^{1}$ Adrian AS Zuckerman, 'Justice in Crisis: Comparative Dimensions of Civil Procedure' in Adrian AS Zuckerman (ed), Civil Justice in Crisis (Oxford University Press 1999) 3, 3.

${ }^{2}$ Ibid.

${ }^{3}$ Richard A Posner, Economic Analysis of Law (Wolters Kluwer, $7^{\text {th }}$ ed, 2007) 593 (emphasis added, citations omitted).
} 


\section{Moral harm}

Ronald Dworkin:

The violation of a legal right 'constitutes a special kind of harm', which can be described as 'moral harm' suffered by the person whose rights are violated. ${ }^{4}$ The general law of a community 'provides a record of its assessment of the relative importance of moral harm' ${ }^{5}$ Litigants have two procedural rights. First, there is a 'right that the legislature fix civil procedures that correctly assess the risk and importance of moral harm'. ${ }^{6}$ Secondly, the parties to a particular case are entitled to 'a consistent evaluation of [moral] harm as compared with the procedures afforded others in different cases." ${ }^{\prime 7}$ This means that judges making individual procedural decisions must ensure that the decisions are 'consistent with the community's own evaluation of moral harm embedded in the law as a whole'. ${ }^{8}$

\section{Process values}

Robert S Summers:

'It is possible to evaluate not only the results of a process, but the process, too. ${ }^{\prime}$ 'I use the phrase "process values" to refer to standards of value by which we may judge a legal process to be good as a process, apart from any 'good result efficacy' it may have. ${ }^{10}$ '[A] legal process can be good, as a process, in two possible ways, not just one: It can be good not only as a means to good results, but also as a means of implementing or serving process values such as participatory governance, procedural rationality, and humaneness. ${ }^{, 11}$

\footnotetext{
${ }^{4}$ Ronald Dworkin, A Matter of Principle (Clarendon Press, 1986), 80.

5 Ibid 89.

${ }^{6}$ Ibid 93.

7 Ibid 92-3.

8 Ibid 89.

9 Robert S Summers, 'Evaluating and Improving Legal Processes - A Plea for “Process Values"' (1974) 60 Cornell Law Review 1, 1 (emphasis in original).

${ }^{10}$ Ibid 3 (emphasis in original).

${ }^{11}$ Ibid 4 (emphasis in original).
} 


\section{BIBLIOGRAPHY \\ I ARTICLES/BOOKS/BOOK CHAPTERS/THESES}

Aldisert, Ruggero J, 'A Metropolitan Court Conquers Its Backlog' (1968) 51 Judicature 202

Alexander, Larry, 'Are Procedural Rights Derivative Substantive Rights?' (1998) Law and Philosophy 19

Andrews, Neil, 'The Adversarial Principle: Fairness and Efficiency: Reflections on the Recommendations of the Woolf Report' in AAS Zuckerman and Ross Cranston, Reform of Civil Procedure: Essays on 'Access to Justice' (Clarendon Press, 1995)

Appleby, Gabrielle, The Constitutional Role of the Solicitor-General: An Historical, Legal and Lived Portrait (PhD thesis, University of Adelaide, 2012)

Armstrong, Nick, 'Making Tracks' in AAS Zuckerman and Ross Cranston (eds), Reform of Civil Procedure: Essays on 'Access to Justice' (Clarendon Press, 1995) 97 Aronson, Mark, Bruce Dyer and Matthew Groves, Judicial Review of Administrative Action (Lawbook Co, $4^{\text {th }}$ ed, 2009)

Aronson, Mark and Matthew Groves, Judicial Review of Administrative Action (Lawbook Co, $5^{\text {th }}$ ed, 2013)

Attrill, Wayne J, 'The Future of Litigation Funding in Australia' in Michael Legg (ed), The Future of Dispute Resolution (LexisNexis Butterworths, 2013) 167

Barker, Andrew, 'Ideas on the Purpose of Civil Procedure' (2002) New Zealand Law Review 437

Bateman, Will, 'Procedural Due Process Under the Australian Constitution' (2009) 31 Sydney Law Review 411

Bayles, Michael, ‘Principles For Legal Procedure' (1986) 5 Law and Philosophy 33

Bayles, Michael D, Procedural Justice (Kluwers Academic Publishers, 1990)

Bell, Evan, 'Judicial Case Management' (2009) Judicial Studies Institute Journal 76

Bentham, Jeremy, Principles of Judicial Procedure in John Bowring (ed), The Works of Jeremy Bentham Vol II (William Tait, 1843) 5 
Bone, Robert G, 'Rethinking the "Day in Court" Ideal and Nonparty Preclusion' (1992) 67 New York University Law Review 255

Bone, Robert, 'Making Effective Rules: The Need for Procedure Theory' (2008) 61 Oklahoma Law Review 319

Boniface, Dorne and Michael Legg, 'Cost, Delay and Justice: The High Court of Australia Recognizes the Importance of Case Management in Civil Litigation - Aon Risk Services Australia v Australian National University' (2010) 39 Common Law World Review 157

Lord Bowen, 'Law Courts Under the Judicature Acts' (1886) 2 Law Quarterly Review 1 Lord Bowen, 'Progress in the Administration of Justice During the Victorian Period', in Select Essays in Anglo-American Legal History Volume 1 (Little, Brown and Company, 1908)

Brennan, Gerard, 'Key Issues in Judicial Administration' (1996) 6 Journal of Judicial Administration 138

Cairns, Bernard, Australian Civil Procedure (Thomson Reuters, $9^{\text {th }}$ ed, 2011)

Cameron, Camille, 'New Directions for Case Management in Australia' (2010) 29 Civil Justice Quarterly 337

Campbell, Enid, 'Rules of Evidence and the Constitution' (2000) 26 Monash University Law Review 313

Cane, Peter and Herbert M Kritzer (eds), The Oxford Handbook of Empirical Legal Research (Oxford University Press, 2010)

Carcopino, Jerome, Daily Life in Ancient Rome (EO Lorimer trans, George Routledge \& Sons, 1941)

Craig, Paul, Administrative Law (Sweet \& Maxwell, $7^{\text {th }}$ ed, 2012)

Cranston, Ross, 'Complex Litigation: The Commercial Court' (2007) 26 Civil Justice Quarterly 190

Creyke, Robin and John McMillan, Control of Government Action (LexisNexis Butterworths, $3^{\text {rd }}$ ed, 2012)

Davies, Justice GL, 'Fairness in a Predominantly Adversarial System' in Helen Stacy and Michael Lavarch (eds) Beyond the Adversarial System (Federation Press, 1999) 102 
Davies, Justice GL, 'Civil Justice Reform in Australia' in Adrian AS Zuckerman (Ed), Civil Justice in Crisis (Oxford University Press, 1999) 166

Davies, Justice GL, 'The Reality of Civil Justice Reform: Why We Must Abandon the Essential Elements of Our System' (2003) 12 Journal of Judicial Administration 155

Dehn, Conrad, 'The Woolf Report: Against the Public Interest' in AAS Zuckerman and Ross Cranston (eds), Reform of Civil Procedure: Essays on 'Access to Justice' (Clarendon Press, 1995) 149

Denzin, Norman K, Interpretive Interactionism (Sage, 1989)

Devereux, JA, 'Providing Expert Evidence in an Australian Court: A Lawyer's View' in Roy G Beran, Legal and Forensic Medicine (Springer, 2013) 1007

Down, Craig, 'Crying Woolf? Reform of the Adversarial System in Australia' (1998) 7 Journal of Judicial Administration 213

Doyle, Chief Justice John, 'The Machine of Justice - Who is Driving It?' (2007) 28 Adelaide Law Review 7

Drummond, Justice Douglas, 'Towards a More Compliant Judiciary? - Part 1' (2001) 75 Australian Law Journal 304

Dworkin, Ronald, Taking Rights Seriously (Gerald Duckworth, 1978)

Dworkin, Ronald, A Matter of Principle (Clarendon Press, 1986)

Edmond, Gary, 'Judging Surveys: Experts, Empirical Evidence and Law Reform' (2005) 33 Federal Law Review 95

Edmond, Gary, 'Secrets of the Hot Tub: Expert Witnesses, Concurrent Evidence and Judge-Led Reform in Australia' (2008) 27 Civil Justice Quarterly 51

Einstein, Justice Clifford, 'Reflections on the Commercial Litigation Landscape Lessons From the Past - Moving Forward' (2005) 26 Australian Bar Review 145

Elliott, ED, 'Managerial Judging and the Evolution of Procedure' (1986) 53 University of Chicago Law Review 306

Emmett, Justice Arthur R, 'Towards the Civil Law? The Loss of "Orality” in Civil Litigation in Australia' (2003) 26 University of New South Wales Law Journal 447 Freckelton, Ian and Hugh Selby, Expert Evidence (Thomsons looseleaf) 
French, Rebecca R, 'Time in the Law' (2001) 72 University of Colorado Law Review 663

Galanter, Marc, Frank S Palen and John M Thomas, 'The Crusading Judge: Judicial Activism in Trial Courts' (1979) 52 Southern California Law Review 699

Gava, John, Sir Owen Dixon: A Strict and Complete Legalist? His Contract Decisions Examined (PhD thesis, University of Adelaide, 2010)

Geertz, Clifford, 'Thick Description: Toward an Interpretive Theory of Culture' in Clifford Geertz (ed), The Interpretation of Cultures (Basic Books, 1973) 3

Gleeson, Chief Justice AM, 'Individualised Justice - The Holy Grail' (1995) 69 Australian Law Journal 421

Gleeson, Chief Justice Murray, 'Some Legal Scenery' (2008) 8 The Judicial Review 415

Gleeson, Chief Justice Murray, 'The Judicial Method: Essentials and Inessentials' (2010) 9 The Judicial Review 377

Grave, Damian, Ken Adams and Jason Betts, Class Actions in Australia (Lawbook, $2^{\text {nd }}$ ed, 2012)

Gravelle, Hugh, 'Regulating the Market for Civil Justice' in AAS Zuckerman and Ross Cranston (eds), Reform of Civil Procedure: Essays on 'Access to Justice' (Clarendon Press, 1995) 279

Gross, Samuel R, 'The American Advantage: The Value of Inefficient Litigation' (1986) 85 Michigan Law Review 734

Hamilton, John P, 'Thirty Years of Civil Procedure Reform in Australia: A Personal Reminiscence' (2005) 26 Australian Bar Review 258

Hanycz, Colleen M, 'More Access to Less Justice: Efficiency, Proportionality and Costs in Canadian Civil Justice Reform' (2008) 27 Civil Justice Quarterly 98

Hazard, Geoffrey, 'Rationing Justice' (1965) 8 Journal of Law and Economics 1

Higgins, Andrew, 'The Costs of Case Management: What Should be Done PostJackson?' (2010) 29 Civil Justice Quarterly 317

Hutchinson, Allan C, 'The Formal and Informal Schemes of the Civil Justice System: A Legal Symbiosis Explored' (1981) 19 Osgoode Hall Law Journal 473 
Ipp, Justice DA, 'Opportunities and Limitations for Change in the Australian Adversary System' in Helen Stacy and Michael Lavarch (eds), Beyond the Adversarial System (Federation Press, 1999) 68

Ipp, Justice DA, 'Reforms to the Adversarial Process in Civil Litigation - Part 1' (1995) 69 Australian Law Journal 705

Ipp, Justice DA, 'Judicial Intervention in the Trial Process' (1995) 69 Australian Law Journal 365.

Jacob, Sir Jack IH, 'The Reform of Civil Procedural Law' in Sir Jack IH Jacob, The Reform of Civil Procedural Law (Sweet \& Maxwell, 1982) 1

Jacob, Sir Jack IH, 'Accelerating the Process of Law' in Sir Jack IH Jacob, The Reform of Civil Procedural Law (Sweet \& Maxwell, 1982) 91

Jacob, Jack IH, 'Civil Procedure Since 1800' in Sir Jack IH Jacob, The Reform of Civil Procedural Law (Sweet \& Maxwell, 1982) 193

Jacob, Sir Jack, The Fabric of English Civil Justice (1987)

JA Jolowicz, On Civil Procedure (Cambridge University Press, 2000)

Kahneman, Daniel, Thinking, Fast and Slow (Penguin, 2011)

Kahneman, Daniel and Gary Klein, Conditions for Intuitive Expertise: A Failure to Disagree (2009) 64 American Psychologist 515

Kaplow, Louis, 'The Value of Accuracy in Adjudication: An Economic Analysis' (1994) 23 Journal of Legal Studies 307

Kaufman, Irving R, 'Courts in Crisis' (1966) 52 American Bar Association Journal 1026

King, Michael et al, Non-Adversarial Justice (Federation Press, $2^{\text {nd }}$ ed, 2014)

Lacey, Wendy, 'Inherent Jurisdiction, Judicial Power and Implied Guarantees Under Chapter III of the Constitution' (2003) 31 Federal Law Review 57

Lavarch, Michael, 'Fighting the Fiends From Finance' in Helen Stacy and Michael Lavarch (eds), Beyond the Adversarial System (Federation Press 1999) 10

Legard, Robin, Jill Keegan and Kit Ward, 'In-depth Interviews' in Jane Ritchie and Jane Lewis (eds), Qualitative Research Practice (Sage Publications, 2003) 138

Legg, Michael, Case Management and Complex Civil Litigation (Federation Press, 2011) 
Legg, Michael, 'Electronically Stored Information and Social Media: Implications for Discovery and Evidence' in Michael Legg (ed), The Future of Dispute Resolution (LexisNexis, 2013) 61

Levine, Robert, A Geography of Time (Basic Books 1997)

Lewis, Jane and Ritchie, Jane, 'Generalising from Qualitative Research' in Jane Ritchie and Jane Lewis (eds), Qualitative Research Practice (Sage Publications, 2003) 263

Lind, E Allan et al, 'In the Eye of the Beholder: Tort Litigants' Evaluations of Their Experiences in the Civil Justice System' (1990) 24 Law and Society Review 953

Mackenzie, Mackenzie, How Judges Sentence (Federation Press, 2005)

Mahoney, Justice DL, 'Delay...A Judge's Perspective' (1983) 57 Australian Law Journal 30

Marcus, Richard L, 'Reassessing the Magnetic Pull of Mega cases on Procedure' (2001) 51 DePaul Law Review 457

Mason, Sir Anthony, 'The Courts as Community Institutions' (1998) 9 Public Law Review 83

McClellan, Justice Peter, 'New Method With Experts - Concurrent Evidence' (2011) 3 Journal of Court Innovation 259

McGregor, Damian, 'Outsourcing Justice? Court-appointed Examiners and the Management of Complex Litigation in the New South Wales Supreme Court' (2002) 11 Journal of Judicial Administration 116

McHugh, Justice Michael, 'Does Chapter III of the Constitution Protect Substantive as Well as Procedural Rights?' (2001) 21 Australian Bar Review 235

Meredith, Martin, 'Mega-Litigation Tales From Bell, C7 and BCCI - Lessons Still to be Learnt (Part 1)' (2013) (March) Law Society Bulletin 10

Meredith, Martin, 'Mega-Litigation Tales From Bell, C7 and BCCI - Lessons Still to be Learnt (Part 2)' (2013) (April) Law Society Bulletin 26

Menkel-Meadow, Carrie J and Bryant G Garth, 'Civil Procedure and Courts' in Peter Cane and Herbert M Kritzer (eds), The Oxford Handbook of Empirical Legal Research (Oxford University Press, 2010) 679 
Meredith, Martin, 'Mega-Litigation Tales From Bell, C7 and BCCI - Lessons Still to be Learnt (Part 2)' (2013) (April) Law Society Bulletin 26

Miles, Matthew B and A Michael Huberman, Qualitative Data Analysis (Sage Publications, $2^{\text {nd }}$ ed, 1994)

Miller, Geoffrey P, ‘Introduction: Economic Analysis of Civil Procedure’ (1994) 23 Journal of Legal Studies 304

Millett, Stephan, 'Ethics of Expert Evidence' (2013) 87 Australian Law Journal 628

Murray, Sarah, The Remaking of the Courts: Less-Adversarial Practice and the Constitutional Role of the Judiciary in Australia (Federation Press, 2014)

Nicholson, Justice Robert D, 'The Paperless Court? Technology and Courts in the Region' (2002) 12 Journal of Judicial Administration 63

Odgers, WB, 'Changes in Procedure and in the Law of Evidence' in A Century of Law Reform (Macmillan \& Co, 1901) 203

Parker, Christine, 'Protection of Judicial Process as an Implied Constitutional Principle' (1994) 16 Adelaide Law Review 341

Parker, Stephen, 'Islands of Civic Virtue? Lawyers and Civil Justice Reform' (1997) 6 Griffith Law Review 1

Patton, Michael Quinn, Qualitative Research and Evaluation Methods (Sage Publications, $3^{\text {rd }}$ ed, 2002)

Peckham, Robert F, 'The Federal Judge as a Case Manager: The New Role in Guiding a Case from Filing to Disposition' (1981) 69 California Law Review 770

Pincus, CW, 'Court Involvement in Pre-Trial Procedures' (1987) 61 Australian Law Journal 471

Polden, Patrick, 'The Judicature Acts' in The Oxford History of the Laws of England (Oxford University Press, 2010) vol XI, 757

Ponterotto, Joseph G, 'Brief Note on the Origins, Evolution, and Meaning of the Qualitative Research Concept “Thick Description”' (2006) 11 The Qualitative Report 538

Posner, Richard A, Economic Analysis of Law (Little, Brown and Company, $2^{\text {nd }}$ ed, 1972) 
Posner, Richard A, 'An Economic Approach to Legal Procedure and Judicial Administration' (1973) 2 Journal of Legal Studies 399

Posner, Judge Richard A, Economic Analysis of Law (Wolters Kluwer, 7th ed, 2007)

Posner, Judge Richard A, How Judges Think (Harvard University Press 2008)

Pound, Roscoe, 'The Causes of Popular Dissatisfaction With the Administration of Justice' (1906) 40 American Law Review 729

Rares, Steven, 'What Is a Quality Judiciary?' (2011) 20 Journal of Judicial Administration 133

Rawls, John, A Theory of Justice (Bellknap Press of Harvard University Press, 1971)

Redish, Martin H and Lawrence C Marshall, 'Adjudicatory Independence and the Values of Procedural Due Process' (1986) 95 Yale Law Journal 455

Resnik, Judith, 'Managerial Judges' (1982) 96 Harvard Law Review 374

Resnik, Judith, ‘Precluding Appeals' (1985) 70 Cornell Law Review 603

Resnik, Judith, 'Changing Practices, Changing Rules: Judicial and Congressional Rulemaking on Civil Juries, Civil Justice, and Civil Judging' (1997) 49 Alabama Law Review 133

Riethmuller, Grant T, ‘District Court Practice and Procedure' (1997) 17 Queensland Lawyer 151

Ritchie, Jane, Jane Lewis and Gillian Elam, 'Designing and Selecting Samples' in Jane Ritchie and Jane Lewis (eds), Qualitative Research Practice (Sage Publications, 2003) 77 Roach Anleu, Sharon and Kathy Mack, 'Magistrates' Everyday Work and Emotional Labour' (2005) 32 Journal of Law and Society 590

Rogers, Andrew, 'The Managerial or Interventionist Judge' (1993) 3 Journal of Judicial Administration 96

Rose, Alan, 'The Model Judiciary - Fitting in with Modern Government' (1999) 4 The Judicial Review 323

Sackville, Ronald, 'Reforming the Civil Justice System: The Case for a Considered Approach' in Helen Stacy and Michael Lavarch (eds), Beyond the Adversarial System (Federation Press, 1999) 34 
Sackville, Justice Ronald, 'Courts in Transition: An Australian View' (2003) New Zealand Law Review 185

Sackville, Justice Ronald, 'Mega-Litigation: Towards a New Approach' (2008) 8 The Judicial Review 89

Sackville, Justice Ronald, 'The Future of Case Management in Litigation' (2009) 18 Journal of Judicial Administration 211

Sackville, Acting Justice of Appeal Ronald, 'Mega-Lit: Tangible Consequences Flow From Complex Case Management' (2010) Law Society Journal 47

Sackville, Acting Justice of Appeal Ronald, 'Access to Justice: Towards an Integrated Approach' (2010) 11 The Judicial Review 221

Sallman, Peter A, 'The Impact of Caseflow Management on the Judicial System' (1995) 18 University of New South Wales Law Journal 193

Schwarzer, William W, 'Case Management in the Federal Courts' (1996) 15 Civil Justice Quarterly 141

Scott, IR, 'Is Court Control the Key to Reduction in Delays?' (1983) 57 Australian Law Journal 16

Scott, IR, 'Caseflow Management in the Trial Court' in AAS Zuckerman and Ross Cranston, Reform of Civil Procedure: Essays on 'Access to Justice' (Clarendon Press, 1995) 1

Selden, John, Table Talk (1689)

Sorabji, John, 'Late Amendment and Jackson's Commitment to Woolf: Another Attempt to Implement a New Approach to Civil Justice' (2012) 31 Civil Justice Quarterly 393

Sourdin, Tania, 'Judicial Management and Alternative Dispute Resolution Trends' (1996) 14 Australian Bar Review 185

Spence, George, First Address to the Public, and More Especially to the Members of the House of Commons, on the Present Unsatisfactory State of the Court of Chancery; and Suggestions for an Immediate Remedy (W Walker and Ridgways, $2^{\text {nd }}$ ed, 1839)

Spigelman, Chief Justice JJ, 'Citizens, Consumers and Courts' (2001) 60 Australian Journal of Public Administration 5 
Spigelman, Chief Justice JJ, 'The "New Public Management" and the Courts' (2001) 75 Australian Law Journal 748

Spigelman, Chief Justice JJ, 'Economic Rationalism and the Law' (2001) 24 University of New South Wales Law Journal 200

Stanfield, Allison, Computer Forensics, Electronic Discovery and Electronic Evidence (LexisNexis, 2009)

Stellios, James, The Federal Judicature: Chapter III of the Constitution (LexisNexis Butterworths, 2010)

Summers, Robert S, 'Evaluating and Improving Legal Processes - A Plea for "Process Values"' (1974) 60 Cornell Law Review 1

Thibaut, John and Laurens Walker, Procedural Justice (Hillsdale, 1975)

Tydings, Joseph D, 'A Fresh Approach to Judicial Administration' (1966) 50 Judicature 44

Tyler, Tom R, ‘Procedural Justice and the Courts' (2007) 44 Court Review 26

Vickery, Justice Peter 'Managing the Paper: Taming the Leviathan' (2012) 22 Journal of Judicial Administration 51

Walker, Laurens, E Allan Lind and John Thibaut, 'The Relation Between Procedural and Distributive Justice' (1979) 65 Virginia Law Review 1401

Webley, Lisa, 'Qualitative Approaches to Empirical Legal Research' in Peter Cane and Herbert M Kritzer (eds), The Oxford Handbook of Empirical Legal Research (Oxford University Press, 2010)

Wheeler, Fiona, 'The Doctrine of Separation of Powers and Constitutionally Entrenched Due Process in Australia' (1997) 23 Monash University Law Review 248

Wheeler, Fiona, 'Due Process, Judicial Power and Chapter III in the New High Court' (2004) 32 Federal Law Review 205

Williams, George and David Hume, Human Rights Under the Australian Constitution (Oxford University Press, $2^{\text {nd }}$ ed, 2013)

Winterton, George, 'The Separation of Judicial Power as an Implied Bill of Rights' in Geoffrey Lindell (ed), Future Directions in Australian Constitutional Law (Federation Press, 1994) 185 
Woolf, Harry, Jeffrey Jowell and Andrew Le Sueur, De Smith's Judicial Review (Sweet \& Maxwell, $6^{\text {th }}$ ed, 2007)

Zines, Leslie, The High Court and the Constitution (Federation Press, $5^{\text {th }}$ ed, 2008)

Zuckerman, AAS, 'Reform in the Shadow of Lawyers' Interests' in AAS Zuckerman and Ross Cranston (eds), Reform of Civil Procedure: Essays on 'Access to Justice' (Clarendon Press, 1995) 61

Zuckerman, AAS, ‘Quality and Economy in Civil Procedure: The Case for Commuting Correct Judgments for Timely Judgments' (1994) Oxford Journal of Legal Studies 353

Zuckerman, AAS, 'A Reform of Civil Procedure - Rationing Procedure rather than Access to Justice' (1995) 22 Journal of Law and Society 155

Zuckerman, AAS, 'Lord Woolf's Access to Justice: Plus ça change...' (1996) 59 Modern Law Review 773

Zuckerman, Adrian AS, 'Justice in Crisis: Comparative Dimensions of Civil Procedure' in Adrian AS Zuckerman (ed), Civil Justice in Crisis (Oxford University Press, 1999) 3

Zuckerman, Adrian, 'A Colossal Wreck - The BCCI-Three Rivers Litigation' (2006) 25 Civil Justice Quarterly 287

Zuckerman, Adrian, Zuckerman on Civil Procedure: Principles of Practice (Sweet and Maxwell, $2^{\text {nd }}$ ed, 2006)

Zuckerman, Adrian, 'Litigation Management Under the CPR: A Poorly-Used Management Infrastructure' in Deirdre Dwyer (ed), The Civil Procedure Rules Ten Years On (Oxford University Press, 2009) 89

\section{REPORTS \& OTHER LAW REFORM MATERIALS}

Access to Justice Advisory Committee, Access to Justice: an Action Plan, AGPS, Canberra, 1994

Access to Justice Taskforce, Attorney-General's Department (Cth), A Strategic Framework for Access to Justice in the Federal Civil Justice System, September 2009 Australian Law Reform Commission, Managing Justice: A Review of the Federal Civil Justice System, Report No 89 (2000) 
Australian Law Reform Commission, Managing Discovery: Discovery of Documents in Federal Courts, Report No 115 (2011)

Commission of Inquiry into Poverty, Law and Poverty in Australia, Second Main Report (R Sackville, Commissioner for Law and Poverty), Australian Government Publishing Service, October 1975

Lord Justice Jackson, Review of Civil Litigation Costs: Final Report (2009)

Judicial Conference of the United States, Procedure in Anti-Trust and Other Protracted Cases (1951), reprinted in (1951) 13 Federal Rules Decisions 41, 65

Judiciary of England and Wales, Report and Recommendation of the Commercial Court Long Trials Working Party (December 2007)

Kakalik, James S, et al, Just, Speedy and Inexpensive? An Evaluation of Judicial Case Management Under the Civil Justice Reform Act (Rand, 1996)

Law Council of Australia, 'Regulation of Third Party Litigation Funding in Australia' (Position Paper, June 2011)

Marketshare Pty Ltd, Community and Client Perceptions of the Queensland Court System (1991) cited in BC Cairns, 'Lord Woolf's Report on Access to Justice: An Australian Perspective' (1997) 16 Civil Justice Quarterly 98

Matruglio, Tania, Plaintiffs and the Process of Litigation: An Analysis of the Perceptions of Plaintiffs following their Experience of Litigation (Law Foundation of NSW, Sydney, 1994)

New South Wales Law Reform Commission, Expert Witnesses, Report 109 (June 2005) Office of the Legal Services Commissioner (NSW), The Regulation of Third Party Litigation Funding in Australia: Discussion Paper (March 2012)

Parliament of Victoria Law Reform Committee, Technology and the Law (May 1999) Peysner, John and Mary Seneviratne, The Management of Civil Cases: The Courts and Post-Woolf Landscape (UK Department of Constitutional Affairs, DCA Research Series 9/05, November 2005)

Productivity Commission, Access to Justice Arrangements: Issues Paper (September 2013)

Productivity Commission, Access to Justice Arrangements: Draft Report (April 2014) 
Sage, Caroline and Ted Wright with Carolyn Morris, Case Management Reform: A Study of the Federal Court's Individual Docket System (Law and Justice Foundation, June 2002)

Schetzer, Louis, Joanna Mullins and Roberto Buonamano, Access to Justice and Legal Needs: A Project to Identify Legal Needs, Pathways and Barriers For Disadvantaged People in NSW (Law and Justice Foundation of NSW, Sydney, 2002)

Senate Legal and Constitutional Affairs References Committee, Impact of Federal Court Fee Increases Since 2010 on Access to Justice in Australia, June 2013

Standing Committee of Attorneys-General, 'Litigation Funding in Australia' (Discussion Paper, May 2006)

Victorian Law Reform Commission, Civil Justice Review Report (March 2008)

Lord Woolf, Access to Justice: Interim Report to the Lord Chancellor on the Civil Justice System in England and Wales (June 1995)

Lord Woolf, Access to Justice: Final Report to the Lord Chancellor on the Civil Justice System in England and Wales (1996)

\section{SPEECHES/PAPERS}

Allsop, Chief Justice James, 'Judicial Case Management and the Problem of Costs' (Speech at the Lord Dyson lecture on 'The Jackson Reforms to Civil Justice in the UK', Sydney, 9 September 2014)

Atiyah, PS, 'From Principles to Pragmatism', Oxford University, 17 February 1978 (Clarendon Press)

Bleby, Justice David, 'The First Electronic Trial, South Australian Supreme Court', paper prepared at the request of the Historical Collections Librarian of the Supreme Court library for the purpose of recording some of the judge's reactions as trial Judge to the electronic aspects of the trial, October 2002

Church, Thomas, W 'A Consumer's Perspective on the Courts' (Second Annual Oration in Judicial Administration, delivered on 31 October 1990 at Melbourne University)

Clarke, Anthony, 'The Supercase - Problems and Solutions: Reflections on BCCI and Equitable Life' (KPMG Forensic's Annual Law Lecture 2007, London, 29 March 2007) 
Doyle, Chief Justice John, 'Imagining the Past, Remembering the Future - the Demise of Civil Litigation' ( $8^{\text {th }}$ Gerard Brennan Lecture, delivered at Bond University, 24 June 2011)

Evans, Simon and John Williams, 'Appointing Australian Judges: A New Model' (Paper presented at the Judicial Conference of Australia Colloquium, Canberra, 7-9 October 2006)

Gleeson, Chief Justice Murray, 'Managing Justice in the Australian Context' (Paper presented to Australian Law Reform Commission Conference, Sydney, 19 May 2000)

Gray, Rachael, 'Legal “Truth”, Judicial Method and Chapter III' (Paper presented to the Australian Association of Constitutional Law, Sir Samuel Way Building, Adelaide, 13 April 2011)

Hayne, Justice Ken, 'Aspects of Justice Reform' (Paper presented to Supreme and Federal Court Judges' Conference, Perth, 25-30 January 1998)

Hayne, Justice Ken, 'The Vanishing Trial' (Paper delivered at Supreme and Federal Courts Judges Conference, Sydney, 23 January 2008)

Keane, Justice PA, 'Access to Justice and Other Shibboleths' (Paper presented to JCA Colloquium, Melbourne, 10 October 2009)

Owen, Justice Neville, 'Surpassing Sisyphus - Idle Musings on Surviving Long Trials' (Paper presented at Supreme Court of Victoria Judges' Conference, Mornington Peninsula, 5 November 2009)

Owen, Justice Neville, 'Farewell to the Honourable Justice Neville Owen' (Retirement speech delivered at special sitting of the Supreme Court of Western Australia, 2 July 2010

Pagone, GT, 'Litigation and ADR' (Speech delivered at Construction Law Conference, Melbourne, 22 May 2008)

Prashar, Baroness Usha, 'Speech at the Annual ILEX Luncheon' (Clothworkers' Hall, London, 17 May 2006)

Rares, Justice Steven, 'Using the "Hot Tub" - How Concurrent Expert Evidence Aids Understanding Issues' (paper presented at the New South Wales Bar Association Continuing Professional Development seminar: Views of the "Hot Tub" from the Bar and the Bench, Bar Association Common Room, 23 August 2010) 
Solomon, Maureen, Caseflow Management in the Trial Court (American Bar Association Commission on Standards of Judicial Administration, 1973)

Solomon, Maureen, 'The Rationale for Court Leadership: Insights From the US Experience' in Courts Advisory Council, Victoria, Caseflow Management in Australian Courts (November 1988), 96

Spigelman, Chief Justice JJ, 'Forensic Accounting in an Adversary System' (Paper presented at the Fourth Annual National CA Forensic Accounting Conference, Sydney, 4 September 2003)

\section{CASES}

Alstom Power Ltd v Yokogawa Australia Pty Ltd (No 4) [2012] SASC 109

Alstom Ltd v Yokogawa Australia Pty Ltd [2012] SASC 49

American Flange \& Manufacturing Co Inc v Rheem Australia Pty Ltd [1963] NSWR 116

American Flange \& Manufacturing Co Inc v Rheem Australia Pty Ltd [1963] NSWR 1121

Aon Risk Services Australia Ltd v Australian National University (2008) 227 FLR 388

Aon Risk Services Australia Ltd v Australian National University (2009) 239 CLR 175

APLA Ltd v Legal Services Commissioner (NSW) (2005) 224 CLR 322

Applicant VEAL of $2002 v$ Minister for Immigration and Multicultural and Indigenous Affairs (2005) 225 CLR 88

Attorney-General (NT) v Emmerson (2014) 88 ALJR 522

Australian Coal and Shale Employees' Federation v Commonwealth (1953) 94 CLR 621

Australian Federation of Consumer Organisations Inc v Tobacco Institute of Australia Ltd (1991) 98 ALR 670

Australian National University v Chubb Insurance Co of Australia Ltd [2007] ACTSC 82 Australian Securities and Investments Commission v Rich (2003) 21 ACLC 672 Australian Securities and Investments Commission v Rich [2004] NSWSC 1017 Australian Securities and Investments Commission v Rich (2004) 22 ACLC 1125 Australian Securities and Investments Commission v Rich (2004) 22 ACLC 1232 
Australian Securities and Investments Commission v Rich (2004) 49 ACSR 578 Australian Securities and Investments Commission v Rich [2005] NSWSC 489 Australian Securities and Investments Commission v Rich [2005] NSWSC 650 Australian Securities and Investments Commission v Rich [2005] NSWSC 706 Australian Securities and Investments Commission v Rich [2005] NSWSC 939 Australian Securities and Investments Commission v Rich [2005] NSWSC 999 Australian Securities and Investments Commission v Rich (2005) 218 ALR 764 Australian Securities and Investments Commission v Rich (2005) 190 FLR 242 Australian Securities and Investments Commission v Rich [2006] NSWSC 266 Australian Securities and Investments Commission v Rich [2007] NSWSC 39 Australian Securities and Investments Commission v Rich (2009) 236 FLR 1 Bass v Permanent Trustee Co Ltd (1999) 198 CLR 334

Baulderstone Pty Ltd v QIC Pty Ltd [2012] NSWSC 235

Bell Group Ltd (in liq) v Westpac Banking Corporation (1998) 86 FCR 215

Bell Group Ltd v Westpac Banking Corporation (2000) 104 FCR 305

Bell Group Ltd (in liq) v Westpac Banking Corporation (No 3) [2004] WASC 93

Bell Group Ltd (in liq) v Westpac Banking Corporation (2004) 208 ALR 491

Bell Group Ltd (in liq) v Westpac Banking Corporation (No 9) (2008) 39 WAR 1; [2008] WASC 239

Bidder v Bridges (1884) 26 Ch D 1

Black E Decker (Australasia) Pty Ltd v GMCA Pty Ltd [2007] FCA 1623

Bomanite Pty Ltd v Slatex Corp Australia Pty Ltd (1991) 32 FCR 379

Business in Focus (Aust) Pty Ltd v Begun Property Pty Ltd [2006] FCA 264

Byron v Southern Star Group Pty Ltd (1995) 123 FLR 352

Campbells Cash and Carry Pty Ltd v Fostif Pty Ltd (2006) 229 CLR 386 
Carryer v Kelly (1969) 90 WN (Pt 1) (NSW) 566

Chamberlain v Deputy Commissioner of Taxation (1988) 164 CLR 502

Chu Kheng Lim v Minister for Immigration, Local Government and Ethnic Affairs (1992) 176 CLR 1

Clarapede E Co v Commercial Unions Association (1883) 32 WR 262

Clough and Rogers v Frog (1974) 48 ALJR 481

Commonwealth v Melbourne Harbour Trust Commissioners (1922) 31 CLR 1

Commonwealth $v$ Verwayen (1990) 170 CLR 394

Concrete Pty Ltd v Parramatta Design E Developments Pty Ltd (2006) 229 CLR 577

Condon v Pompano Pty Ltd (2013) 228 A Crim R 237

Council of the Municipality of Burwood v Harvey (Unreported, NSWCA, Kirby P, Mahoney and Cole JJA, 3 April 1995)

Cropper v Smith (1889) 26 Ch D 700

Dennis v Australian Broadcasting Corporation [2008] NSWCA 37

Devis v Turnbull (1822) 6 Madd 232

Duke Group Ltd (in liq) v Pilmer (1998) 144 FLR 1

Duke Group Ltd (in liq) v Pilmer (1998) 73 SASR 64

Ebner v Official Trustee in Bankruptcy (2000) 205 CLR 337

EI Du Pont De Nemours \& Co v Commissioner of Patents (1987) 16 FCR 423

Elna Australia Pty Ltd v International Computers (Aust) Pty Ltd (1987) 14 FCR 461

Ex Parte Lloyd (1822) Mont 70

Expense Reduction Analysts Group Pty Ltd v Armstrong Strategic Management and Marketing Pty Ltd (2013) 250 CLR 303

Fardon v Attorney-General (Qld) (2004) 223 CLR 575

Finsbury Print Pty Ltd v CPI Graphics Ltd [2007] SASC 131 
Forge v Australian Securities and Investments Commission (2006) 228 CLR 45

Gale v Superdrug Stores plc [1996] 1 WLR 1089

GSA Industries Pty Ltd v NT Gas Ltd (1990) 24 NSWLR 710

Gypsy Jokers Motorcycle Club Inc v Commissioner of Police (2008) 234 CLR 532

Harris v Caladine (1991) 172 CLR 84

Harris Scarfe Ltd v Ernst E Young (No 3) (2005) 242 LSJS 378

Hogan v Hinch (2011) 243 CLR 506

Idoport Pty Ltd v National Bank Ltd [2000] NSWSC 1215

Idoport Pty Ltd v National Bank Ltd [2000] NSWSC 1250

Idoport Pty Ltd v National Australia Bank Ltd [2001] NSWSC 838

Idoport Pty Ltd v National Australia Bank Ltd [2001] NSWSC 868

Idoport Pty Ltd v National Australia Bank Ltd [2002] NSWSC 18

Idoport Pty Ltd v National Australia Bank Ltd [2002] NSWCA 271

Inamed Development Company v Morton Surgical Pty Ltd (2007) 73 IPR 308

In Re Judiciary and Navigation Acts (1921) 29 CLR 257

International Finance Trust Ltd v New South Wales Crime Commission (2009) 240 CLR 319

In the Marriage of Collins (1990) 14 Fam LR 162

IOOF Australia Trustees Ltd v Seas Sapfor Forests Pty Ltd (1999) 78 SASR 151

Jacobson $v$ Ross [1995] 1 VR 337

Johnson v Gore Wood E Co [2002] 2 AC 1

Jones v National Coal Board [1957] 2 QB 55

Kable v Director of Public Prosecutions (NSW) (1996) 189 CLR 51

Ketteman v Hansel Properties Ltd [1987] AC 189

K-Generation Pty Ltd v Liquor Licensing Court (2009) 237 CLR 501 
Kioa $v$ West (1985) 159 CLR 550

Kirby v Centro Properties Ltd (No 6) [2012] FCA 650

Leeth v Commonwealth (1992) 174 CLR 455

Lord Belmore v Anderson (1792) 2 Cox 288

Macquarie Bank Ltd v National Mutual Life Association of Australia Ltd (1996) 40 NSWLR 543

Maronis Holdings Ltd v Nippon Credit Australia Ltd [2000] NSWSC 753

Maxwell v Keun [1928] 1 KB 645

Micallefv ICI Australia Operations Pty Ltd [2001] NSWCA 274

Mobil Oil Australia Pty Ltd v Federal Commissioner of Taxation (1963) 113 CLR 475

Mobil Oil Australia Pty Ltd v Trendlen Pty Ltd (2006) 80 ALJR 1503

Momcilovic v The Queen (2011) 245 CLR 1

Moodalay v Morton (1785) 1 Br C C 469

Najjer v Haines (1991) 25 NSWLR 224

National Companies and Securities Commission v News Corporation Ltd (1984) 156 CLR 296

New South Wales v Lepore (2003) 212 CLR 511

New South Wales v Mulcahy [2006] NSWCA 303

Nicholas v The Queen (1998) 193 CLR 173

Nine Films $\mathcal{E}$ Television Pty Ltd v Ninox Television Ltd [2005] FCA 357

North Australian Aboriginal Legal Aid Service v Bradley (2004) 218 CLR 146

Pacific Acceptance Corporation Ltd v Forsyth (1970) 92 WN (NSW) 29

Park Rail Developments Pty Ltd v R J Pearce Associates Pty Ltd (1987) 8 NSWLR 123

Perre v Apand Pty Ltd (1999) 198 CLR 180332

Piglowska v Piglowski [1999] 1 WLR 1360 
Polyukhovich v Commonwealth (1991) 172 CLR 501

Queensland v JL Holdings Pty Ltd (Unreported, Federal Court of Australia (Full Court), 29 October 1996)

Queensland v JL Holdings Pty Ltd (1997) 189 CLR 146

$R v$ Kirby; Ex parte Boilermakers Society of Australia (1956) 94 CLR 254

$R v$ Commonwealth Conciliation and Arbitration Commission; Ex parte The Angliss Group (1969) 122 CLR 546

Re Coles and Ravenshear [1907] 1 KB 1

Re Movitor Pty Ltd (in liq) (1996) 64 FCR 380

Re Nolan; Ex parte Young (1991) 172 CLR 460

Re Tracey; Ex parte Ryan (1989) 166 CLR 518

Russell v Duke of Norfolk [1949] 1 All ER 109

Russell v Russell (1976) 134 CLR 495

Sackville-West v Attorney-General (1910) 128 LT Journ 265

Sali v SPC Ltd (1993) 67 ALJR 841

Seven Network Ltd v News Ltd (No 4) (2005) 214 ALR 686

Seven Network Ltd v News Ltd (No 16) [2006] FCA 574

Seven Network Ltd v News Ltd [2007] FCA 1062

Seven Network Ltd v News Ltd (2007) 244 ALR 374

Shannon v Lee Chun (1912) 15 CLR 257

South Australia v Totani (2010) 242 CLR 1

Squire v Rogers (1979) 39 FLR 106

State Pollution Control Commission v Australian Iron \& Steel Pty Ltd (1993) 29 NSWLR 487

Super Pty Ltd v SJP Formwork (Aus) Pty Ltd (1992) 29 NSWLR 549 
Sydney City Council v Ke-Su Investments Pty Ltd (1985) 1 NSWLR 246,

TCL Air Conditioner (Zhongshan) Co Ltd $v$ The Judges of the Federal Court of Australia (2013) 87 ALJR 410

Tepko Pty Ltd v Water Board (2001) 206 CLR 1

The Ampthill Peerage [1977] AC 547

Thomas v Mowbray (2007) 233 CLR 307

Thorpe v Macauley (1820) 5 Madd 218

Three Rivers DC v Bank of England (No 3) [2003] 2 AC 1

Tildesley v Harper (1878) LR 10 Ch D 393

Trade Practices Commission v TNT Management Pty Ltd (1985) 6 FCR 1

Trevorrow $v$ State of South Australia (No 5) (2007) 98 SASR 136

United Motors Retail Ltd v Australian Guarantee Corporation Ltd (1991) 58 SASR 156

Wainohu v New South Wales (2011) 243 CLR 181

Warner v Mosses (1880) 16 Ch D 100

Waterways Authority v Fitzgibbon (2005) 79 ALJR 1816

Westpac Banking Corporation v Bell Group Ltd (in liq) [2009] WASCA 166

Westpac Banking Corporation v Bell Group Ltd (No 2) [2009] WASCA 223

Westpac Banking Corporationv The Bell Group Ltd (in liq) (No 3) (2012) 44 WAR 1

Williamson v Ah On (1926) 39 CLR 95

Worldwide Corporation Ltd v GPT Ltd [1998] EWCA Civ 1894

Xuereb v Viola (1989) 18 NSWLR 453

\section{LEGISLATION}

Australian Constitution

Civil Law (Wrongs) Act 2002 (ACT)

Civil Procedure Act 2005 (NSW) 
Civil Procedure Act 2010 (Vic)

Civil Procedure Rules 1998 (UK)

Civil Procedure Amendment Act 2012 (Vic)

Commercial Arbitration Act 1986 (ACT)

Corporations Act 2001 (Cth)

Court Procedures Rules 2006 (ACT) r 21

Crimes Act 1958 (Vic)

Criminal Law Consolidation Act 1935 (SA)

Federal Court and Federal Circuit Court Regulation 2012 (Cth)

Federal Court of Australia Act 1976 (Cth)

Federal Court Regulations 1978 (Cth)

Federal Court Rules 2011 (Cth)

Federal Rules of Civil Procedure 1937 (US)

High Court Rules 2004 (Cth)

Maintenance, Champerty and Barratry Abolition Act 1993 (NSW)

Rules of the Supreme Court 1971 (WA)

Supreme Court Act (NT)

Supreme Court Act 1935 (SA)

Supreme Court Civil Rules 2006 (SA)

Supreme Court Civil Supplementary Rules 2014 (SA)

Supreme Court (General Civil Procedure) Rules 2005 (Vic)

Supreme Court (Miscellaneous Civil Proceedings Rules) 2008 (Vic)

Supreme Court of Judicature Act 1873 (UK)

Supreme Court of Judicature Act 1875 (UK) 
Supreme Court Rules 1970 (NSW)

Supreme Court Rules (NT)

Supreme Court Rules 2000 (Tas)

Uniform Civil Procedure Rules 2005 (NSW)

Uniform Civil Procedure Rules 1999 (Qld)

Wrongs Act 1958 (Vic)

\section{PARLIAMENTARY MATERIALS}

Second Reading Speech to the Civil Procedure Bill 2005 and Uniform Civil Procedure Rules 2005 (NSW), New South Wales, Legislative Assembly, Parliamentary Debates (Hansard), 6 April 2005, 15115

Explanatory Memorandum, Access to Justice (Civil Litigation Reforms) Amendment Bill 2009 (Cth)

\section{MEDIA RePORTS/PRESS RELEASES/OnLINE RESOURCES}

Federal Court of Australia, 'Individual Docket System'

$<$ http://www.fedcourt.gov.au/case-management-services/case-allocation/individualdocket-system>

Gluyas, Richard, 'Bell Farce Shows Need For Reform', The Australian, 14 September 2013

Gluyas, Richard, 'Banks in Bell Group Settlement', The Australian, 18 September 2013 Lenaghan, Nick, 'Threats to Lawyers in Centro Case', Australian Financial Review, 18 April 2012, 49

Porter, Christian (Attorney-General and Treasurer), 'Three Judges Appointed for Bell Group Appeal' (Media Release, 3 December 2010)

Prior, Neale, ‘WA May Be Big Winner in Bell Group Wrangle', The West Australian (online), 18 April $2011<$ http://au.news.yahoo.com/thewest/business/a//business/9213511/wa-may-be-big-winner-in-bell-group-wrangle/>

Sexton, Elizabeth, 'Judges Turn to Oral Evidence to Cut Paperwork', Sydney Morning Herald, 28 March 2011 
Vaughan, John and Tony Woodings, 'Bell Case Settlement' (Joint Media Statement, 17 September 2013),

$<$ https://www.icwa.wa.gov.au/icwa/news/icwa_bell_settlement_joint_media_statem ent.pdf>

West, Michael, 'Lots of Finger-Pointing? You Betcha' (Sydney Morning Herald, 7 April 2012, 2)

'Celebration', Sydney Morning Herald, 31 May 2006,

$<$ http://www.smh.com.au/news/cbd/doc-spuds-in-miners-

heart/2006/05/30/1148956345146.html?page=fullpage\#> (accessed 10 April 2013)

\section{OTHER COURT MATERIALS}

Federal Court of Australia, Case Management Handbook (13 October 2011)

Federal Court of Australia, Practice Note CM1 - Case Management and the Individual Docket System, 1 August 2011

Federal Court of Australia, Administrative Notice NSW 2 - Corporations Matters, 15 May 2014

Federal Court of Australia, Administrative Notices QLD 1 - Corporations Matters, 1 August 2011

Federal Court of Australia, Administrative Notice WA 1 - Corporations Matters, 25 September 2009

Federal Court of Australia, Class Action and Electronic Trial Guide (2012) (Copy on file with author)

Federal Judicial Center, Manual for Complex Litigation, Fourth (2004)

Aon Risk Services Australia Ltd v Australian National University [2009] HCATrans 26

GMCA Pty Ltd v Black E Decker Inc [2007] HCATrans 662 (14 November 2007)

Westpac Banking Corporation v The Bell Group Ltd [2013] HCATrans 49

Westpac Banking Corporation v The Bell Group Ltd [2013] HCATrans 85

Federal Court of Australia, Practice Note No CM 5 - Discovery, 1 August 2011

Supreme Court of New South Wales, Practice Note SC Eq 11 -Disclosure in the Equity Division, 22 March 2012 
Supreme Court of New South Wales, Practice Note No SC Eq 3 - Supreme Court Equity Division - Commercial List and Technology and Construction List, 12 October 2008 Supreme Court of Queensland, Practice Direction No 3 of 2002 - Commercial List Supreme Court of Queensland, Practice Direction No 11 of 2012 - Supervised Case List Supreme Court of South Australia, Supreme Court Practice Directions 2006 Supreme Court of Victoria, Annual Report 2012-13

Supreme Court of Victoria, Practice Note No 4 of 2004 - Commercial List (2004) 8 VR 480

Supreme Court of Victoria, Practice Note No 10 of 2011 - Commercial Court Supreme Court of Western Australia, Consolidated Practice Directions 2009 